AUTARQUIA ASSOCIADA À UNIVERSIDADE DE SÃO PAULO

\title{
ESPECIAÇÃO DE ALUMÍNIO EM ÁGUAS SUBTERRÂNEAS NA REGIÃO DO MANANCIAL BILLINGS: APLICAÇÃO DA RADIAÇÃO IONIZANTE NA DIGESTÃO AMOSTRAL PARA FINS ANALÍTICOS E NA PROPOSTA DE REMEDIAÇÃO
}

Renata Bazante Yamaguishi

Tese apresentada como parte dos requisitos para obtenção do Grau de Doutor em Ciências na Área de Tecnologia Nuclear - Aplicações

Orientador:

Prof. Dr. José Eduardo Manzoli 


\section{INSTITUTO DE PESQUISAS ENERGÉTICAS E NUCLEARES}

Autarquia associada à Universidade de São Paulo

\section{ESPECIAÇÃO DE ALUMÍNIO EM ÁGUAS SUBTERRÂNEAS NA REGIÃO DO MANANCIAL BILLINGS: APLICAÇÃO DA RADIAÇÃO IONIZANTE NA DIGESTÃO AMOSTRAL PARA FINS ANALÍTICOS E NA PROPOSTA DE REMEDIAÇÃO}

Renata Bazante Yamaguishi

Tese apresentada como parte dos requisitos para obtenção do Grau de Doutor em Ciências na Área de Tecnologia Nuclear - Aplicações

Orientador:

Prof. Dr. José Eduardo Manzoli

Versão Corrigida

$\#$

São Paulo

2013 


\section{Dedicatória}

Dedico este trabalho ao meu bem mais precioso: meu filho Christian Yukio Bazante Yamaguishi

"Quando uma porta se fecha, pode ter certeza que outra sempre estará pronta para ser aberta é só não desistir! Filho, a mamãe nunca desistiu desse sonho!!” 


\section{Agradecimentos}

A Deus pelo dom da vida, da sabedoria, perseverança e amor: sem ele nada seria possível. Obrigada por ter me guiado e ter me dado forças para enfrentar os obstáculos que passei nessa minha jornada. "O senhor é o meu pastor e nada me faltará".

Meus sinceros agradecimentos às pessoas e instituições que tornaram possível a realização deste trabalho. Em especial:

Ao curso de Pós-Graduação do Instituto de Pesquisas Energéticas e Nucleares - IPEN/CNEN pelo conhecimento proporcionado.

Á FAPESP - Fundação de Amparo à Pesquisa do Estado de São Paulo pelo auxílio da bolsa de treinamento técnico (Processo No. 2012/04257-3, vinculada ao Processo No. 2011/23426-8).

Ao prof. Dr. José Eduardo Manzoli, ser humano grandioso e um exemplo de profissional dedicado e integro no que faz. Foi meu amigo e orientador num momento em que eu mais precisava. Obrigada por acreditar na minha capacidade, depositando sua confiança e respeito no meu trabalho. Espero que o futuro permita que trabalhemos juntos muitas outras vezes, pois acredito na sua força interior instintiva. Essa força ainda será propagada em todo seu ser e o tornará mais grandioso como o universo.

À profa. Dra. Áurea Beatriz Cerqueira Geraldo pela acolhida carinhosa, pela sua bondade, simplicidade, generosidade e principalmente pelo incentivo incondicional e imponderável talento para ensinar!! Obrigada por transmitir seus conhecimentos, suas valiosas discussões, dedicação constante e sugestões a este trabalho... sei que essas palavras não pagam pelo que você fez por mim!! Meu coração será eternamente grato! Que Deus a abençoes e toda sua família!

Ao meu esposo Sergio Hideo Yamaguishi, companheiro de todas as horas, pela paciência, respeito, confiança, amizade e compreensão dedicados ao longo desses quinze anos de caminhada. Saiba que você foi essencial na concretização desse sonho!

Ao meu pai Luiz Teixeira Rodrigues e minha mãe Maria da Conceição Bazante Rodrigues, vocês são tudo na minha vida!! Sem o apoio e carinho de vocês, tudo seria muito mais difícil pra mim! Obrigada por cuidar e ajudar a educar o meu bem mais precioso. Vocês são exemplos de dedicação e amor! Que Deus os abençoe!! 
Aos meus irmãos Raquel Bazante Rodrigues e Luiz Schaller Rodrigues pelo apoio incondicional, carinho, vibrações positivas e mesmo estando longe, ainda puderam me ajudar nas revisões no idioma inglês. Muito obrigada!

Ao Dr. Wilson Aparecido Calvo e Dra. Margarida Mizue Hamada, gerentes responsáveis pelo Centro Tecnológico das Radiações (CTR), pelo constante apoio, respeito, carinho e confiança no meu trabalho e, sobretudo por transmitirem a dedicação à pesquisa, além da seriedade, a humildade e a generosidade com os alunos e funcionários do Instituto. Registro aqui o meu respeito e admiração por vocês dois!

Aos funcionários, pesquisadores do IPEN (CTR) que pude trabalhar e compartilhar conhecimentos técnicos de grande valia, além do carinho e amizade: Eduardo Moura, MSc. Hiroshi Oikawa, Carlos Gaia da Silveira, Paulo de Souza Santos, MSc. Samir Luiz Somessari, Elizabeth S. R. Somessari, Hélio Antônio Paes, Carlos A. Medeiros, MSc. Cyro Enokihara, Marcos Cardoso, Cláudia R. Nolla, Francisco Sprenger e os Doutores Nelson Minoru Omi, Leonardo Gondin, Yasko Kodama, Celina Duarte e Luci Diva Brocardo Machado. Do CQMA: Marcos Antônio Hortellani, Helena Miho Shihomatsu, Maurício Hiromitu Kakazu e Alder S. Pereira. De alguma forma, todos contribuíram para minha formação profissional e pessoal.

Aos alunos e ex-alunos do IPEN: Jessica Raquel Cardoso, Camila Pedrozo, Clécia Souza, Ana Cláudia Damião Guedes, Alinésia Reis, Fernando Codelo, Amanda Koike, Ana Carolina Russo, Flávio Tihara, João F. Trencher Martins e Robinson Alves dos Santos pelo convívio divertido e harmonioso, em que o companheirismo foi soberano a qualquer diferença nessa caminhada.

Ao Centro de Ciências e Tecnologia de Materiais - CCTM do IPEN pelo apoio e análises de microscopia eletrônica de varredura (MEV).

Aos pesquisadores e funcionário do Instituto de Geociências da Universidade de São Paulo, em especial ao Dr. Ricardo César Aoki Hirata, Dr. Fernando Augusto Saraiva, Veridiana Martins e Paulo Lima, muito obrigada pelo tempo e atenção, auxílio nas coletas, troca de experiência, apoio e amizade.

Aos pesquisadores e funcionários do Instituto de Pesca, em especial a Dra. Luciana Carvalho Bezerra de Menezes e Paula Maria Gênova de Castro e MSc. Lidia Marayuma, Ocimar Pedro, Cibele dos Santos e Tom Simões. 
À Dra. Adriana Sacioto Marcantonio, pesquisadora científica da Secretaria de Agricultura e Abastecimento do Estado de São Paulo - Pólo Regional de Pindamonhangaba, por acreditar no meu trabalho e profissionalismo. Exemplo de dedicação e apoio no desenvolvimento da pesquisa científica em nosso país. Obrigada pelo carinho e amizade durante esses anos.

À Dra. Rosely Imberon da Escola de Artes Ciência e Humanidade da Universidade de São Paulo, pela experiência em campo e amizade.

Ao Prof. Dr. Eduardo Landulfo, meu carinho e admiração pelo ser humano incrível que pude perceber, além do profissional competente e digno de seus méritos. Quero cultivar nossa amizade e quem sabe um futuro poder trabalhar contigo.

Ao prof. Mark Lofrese pelas valiosas dicas e ensinamento da língua inglesa. Você foi genial!!!

Ao físico e amigo Paulo Afonso G. Fessel pelo carinho e apoio durante o projeto, além da ajuda fundamental nas traduções e revisões na língua inglesa...Serei eternamente grata!!

Ao Sr. Albano (motorista do IPEN) e o Sr. Nunes do CTR que tanto me ajudaram durante as coletas de amostras! Obrigada pelo companheirismo, apoio, respeito e pela amizade.

À amiga, incentivadora e perseverante Edna Maria Alves, bibliotecária do IPEN. Ainda no início de meus estudos, você havia se tornado uma pessoal especial na concretização da minha formação profissional. Não tenho palavras pra lhe dizer o quanto sou grata pelo que me fez, além de ter me proporcionado muitas alegrias. Obrigada por tudo!!

Meus amigos da Ilha do Bororé: Márcia M. Silva, Jacqueline Penha Ribeiro, Sergio Milani, Dona Antônia Maria da Silva, Sr. João da Silva, Patrícia Dias, Janaina Duarte, Admir de Souza (Mi), Marlene Silva, Donizete Casemiro, Sr. Antônio Duarte e Dona Antônia Duarte, Sr. Sérgio Rodrigues (Sérginho), Sr. José Feliciano, Sr. José Renaldo e todos os pescadores e seus familiares.

O meu reconhecimento aos esforços e profissionalismo somado à minha experiência profissional, crescimento intelectual e pessoal: Dra. Juliana de Souza Azevedo, Rackel Reis, Priscila Finni, MSc. Giovanna Teixeira Gimiliani, Tatiana Matias e MSc. Talita de Oliveira. 
O meu respeito, carinho e admiração aos meus amigos que fiz durante minha jornada acadêmica: MSc. Renata Medeiros Lobo Müller, Ernesto Diaz, Saulo Kann, Milana Rocha, Claúdio Yokoo, Luciana Domingues Fiorita, Renata Reiko Suzuki, Daniele Bretanha, Dr. Marcelo Pisetta, Diego Hiroshi Nohal Tanikawa, Milton Katsumi Sasaki e MSc. Anibal Mucchimbane.

A todos familiares e amigos, que de alguma forma contribuíram para a realização e conclusão deste trabalho. 
"Vós sois o sal da terra; e se o sal for insípido, com que se há de salgar? Para nada mais presta senão para se lançar fora, e ser pisado pelos homens". 


\title{
ESPECIAÇÃO DE ALUMÍNIO EM ÁGUAS SUBTERRÂNEAS NA REGIÃO DO MANANCIAL BILLINGS: APLICAÇÃO DA RADIAÇÃO IONIZANTE NA DIGESTÃO AMOSTRAL PARA FINS ANALÍTICOS E NA PROPOSTA DE REMEDIAÇÃO
}

\section{Renata Bazante Yamaguishi}

\begin{abstract}
RESUMO
A represa Billings é o maior manancial superficial do Estado de São Paulo cuja importância está ligada ao abastecimento público, à geração de energia, à pesca, à recreação e ao lazer para a cidade de São Paulo e os municípios da sua região metropolitana. Nos últimos anos essa região vem sofrendo grande impacto ambiental. Apesar de ser uma APA (Área de Proteção Ambiental), há no entorno da represa, vários tipos de assentamentos cujas famílias utilizam para o seu consumo a água proveniente de poços situados, muitas vezes, a poucos metros da represa, já que inexiste o acesso à rede de saneamento básico (tratamento de água e esgoto em rede pública). De acordo com relatórios de entidades governamentais, observa-se que a espécie química alumínio está presente nas águas da represa em valores acima do permitido, o que gera preocupações relacionadas à contaminação do meio ambiente e à saúde da população; por outro lado, há poucas informações sobre a qualidade das águas subterrâneas da região. Considerando-se essa deficiência de informações, este trabalho teve como objetivo investigar a possível contaminação de poços, partindo da aplicação de um programa criado - o PAMQUÁ ${ }^{\circledR}$ - que auxiliou e direcionou à tomada de decisão a um determinado contaminante de risco à saúde humana encontrado na água e como o uso da radiação ionizante pôde ser aplicada no beneficiamento de diagnóstico químico e em solução para tratamento específico. Dessa forma, pôde-se ter o respaldo de que a espécie química alumínio é o principal contaminante daquelas águas superficiais. Como os íons alumínio são susceptíveis à complexação por substâncias orgânicas, o processo de irradiação ionizante como etapa de pré-tratamento para a determinação analítica foi um processo inovador e que foi aplicado em dois tipos de amostra: 1) amostras de água padronizadas contendo ácido húmico, que é o tipo de matéria orgânica que ocorre com frequência em águas subterrâneas e 2) amostras de água coletadas dos poços da região estudada. O processo de irradiação permitiu a redução do teor de matéria orgânica e a mineralização dessas amostras, contribuindo com dados inéditos sobre o teor de alumínio. Finalmente, foi desenvolvido um novo material - uma membrana polimérica seletiva modificada por radiação - que propõe a remediação do alumínio na água.
\end{abstract}




\title{
SPECIATION OF ALUMINUM IN GROUNDWATER ON BILLINGS DAM AREA: APPLICATIONS OF THE IONIZING RADIATION FOR DIGESTING OF WATER SAMPLES AND PROPOSAL OF REMEDIATION
}

\author{
Renata Bazante Yamaguishi
}

\begin{abstract}
The Billings dam is the largest source of water in São Paulo state, whose its importance to São Paulo city and its metropolitan region is closely linked to the public water supply, power generation, fisheries, recreation and leisure. In recent years, the dam region has suffered high environmental impact. Although it is an EPA (Environmental Protection Area), there are in dam surroundings several types of settlements, whose families use water from wells often located a few meters from the dam, once does not have their access to the sanitation (public water and sewage treatment). In accordance to the reports of governmental entities, the aluminum is present in the dam water and its concentration exceeds the permissible values, which raises concerns related to contamination of the environment and the health of the population; by the other side, no information exists about the ground water quality in this region. Considering this deficit of information, the main goal of this work was the investigation of ground water of a potential contamination, based on a new program - PAMQUÁ ${ }^{\circledR}$ - which supported and drove the decision making of a specific contaminant with risk to human health found in water and how the use of ionizing radiation can be applied for processing of chemical diagnose and for specific treatment solution. By this way, it was possible to have support that the chemical specie of aluminum is the main contaminant of that surface water. As aluminum ions are susceptible to organic matter complexation, the ionizing irradiation process applied as pre-treatment step in an analytical determination was an innovative procedure and it covered two kinds of sample: 1) standard water samples containing humic acid, that is the more common type of organic matter in ground water and 2) natural water samples from wells of studied region. The irradiation process allowed the decreasing of the organic matter levels and the mineralization of these water samples contributing with unpublished data about the contents of aluminum. Finally, a new material was developed - a selective polymeric membrane modified by radiation - that suggests the aluminum mitigation in water.
\end{abstract}




\section{SUMÁRIO}

1. INTRODUÇÃ

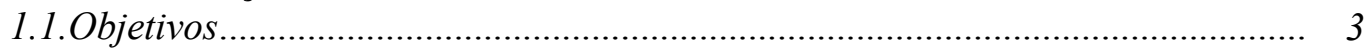

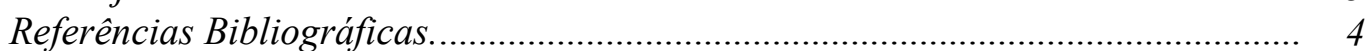

2 CARACTERIZAÇÃO DA ÁREA........................................................... 6

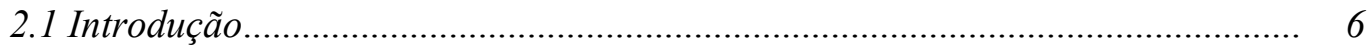

2.2 O maior manancial do Estado de São Paulo........................................................ 8

2.3 A urbanização ao entorno da represa................................................................... 14

2.4 Os problemas de poluição da represa Billings................................................... 15

2.5 Sobre a monitoramento da qualidade da água ................................................ 20

2.6 A água subterrânea ................................................................................. 21

2.7 Características geomorfológicas dos aquíferos em São Paulo............................... 27

2.8 Características climáticas............................................................................... 28

2.9 Legislações e Normatizações de Qualidade de Recursos Hídricos.................... 29

Referências Bibliográficas.................................................................................... 32

3 PROGRAMA AUXILIAR DE MONITORAMENTO DA QUALIDADE DE

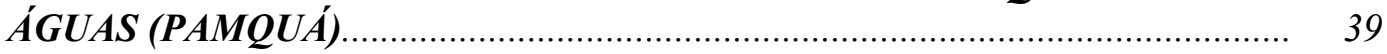

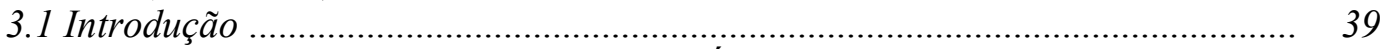

3.2. Elaboração da Arquitetura do PAMQUÁ..................................................... 40

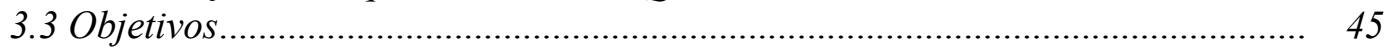

3.4 Materiais e métodos..................................................................................... 45

3.5 Resultados e discussão.............................................................................. 51

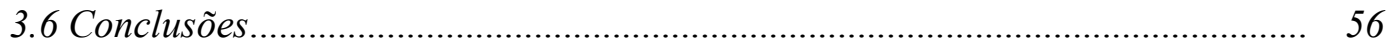

Referências bibliográficas................................................................................ 55

4 DEGRADAÇÃO RADIOLÍTICA DO ÁCIDO HÚMICO: ESTUDO DA PROPOSTA DE PRÉ-TRATAMENTO DE AMOSTRAS DE ÁGUAS DE MANANCIAIS.

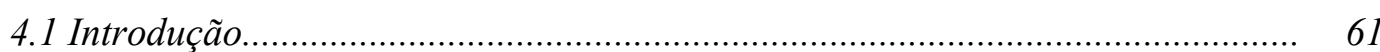

4.1.1 Técnicas de pré-tratamento amostral para análise química.......................... 62

4.1.2 Substâncias húmicas: o estudo do ácido húmico................................................ 65

4.2 Materiais e Métodos....................................................................................... 68

4.2.1 Mineralização......................................................................................... 68

4.2.1.1 Preparo da solução de ácido húmico........................................................ 68

4.2.1.2 Fontes de irradiação........................................................................... $\quad 70$

4.2.2 Análise instrumental.................................................................................. 73

4.2.2.1 Determinação da concentração do AH e análise espectral na região UV-vis.... 73

4.2.2.2 Determinação do carbono orgânico total (COT) ....................................... 73

4.2.2.3 Determinação dos íons alumínio................................................................. 74

4.2.2.3.1 Determinação dos ions alumínio por espectrofotometria $U V$-vis............. 74

4.2.2.3.2 Determinação dos ions alumínio por ICP-OES (espectrofotometria por emissão óptica por plasma indutivo acoplado) ..................................................... 74

4.3 Resultados e Discussão................................................................................... 75

4.3.1 Degradação do AH por radiação gama ........................................................ 75

4.3.2 Análise espectral das soluções de AH.......................................................... 81

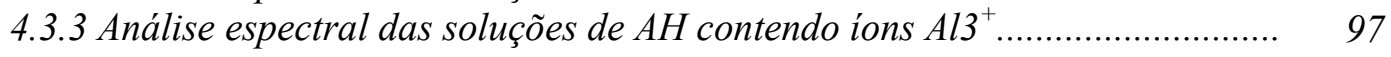

4.3.4 Avaliação da concentração da espécie alumínio em soluções de AH não irradiadas e irradiadas................................................................................. 102

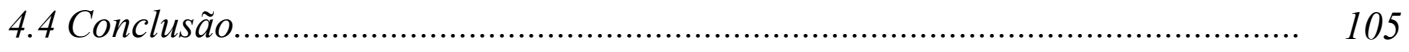


Referências bibliográficas......

5 RADIAÇÃO IONIZANTE NA OTIMIZAÇÃO DO DIAGNÓSTICO DE ALUMÍNIO EM AMOSTRAS DE ÁGUA POTÁVEL.

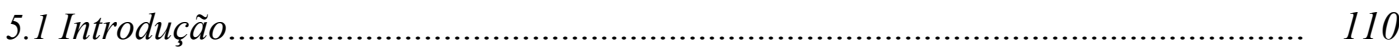

5.1.1 O metal alumínio.................................................................................. 114

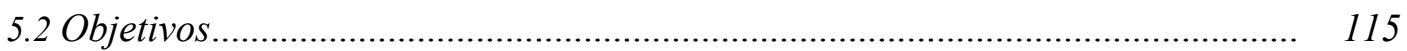

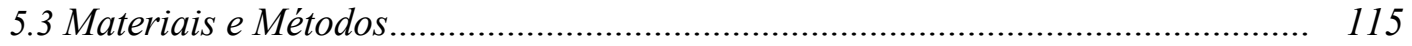

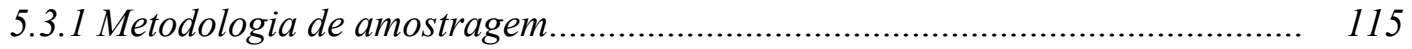

5.3.2. Metodologia de análise química ................................................................. 117

5.3.3 Metodologia de análise microbiológica................................................. 117

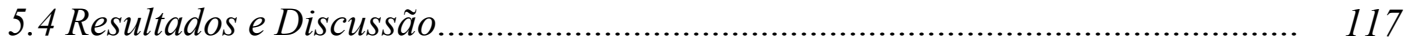

5.4.1 Análises físico-químicas: pH............................................................... 117

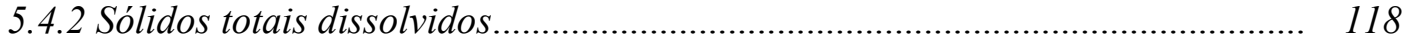

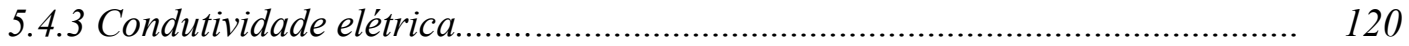

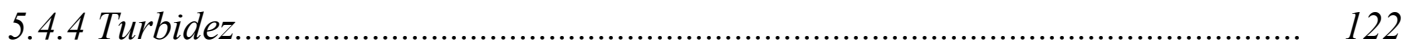

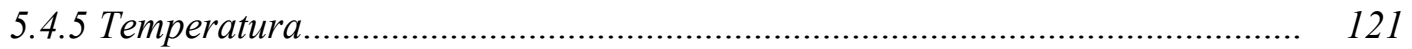

5.4.6 Aplicação da técnica por ICP-OES e UV-vis.............................................. 125

5.4.7 Resultado de COT .............................................................................. 127

5.4.8. Resultado Microbiológico ........................................................................ 128

5.4.9 Interpretação com o PAMQUÁ de dados de domínio público: poços e

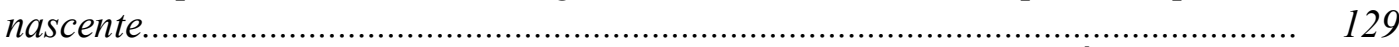

5.4.10. Avaliação do alumínio nas águas dos poços com o PAMQUÁ..................... 130

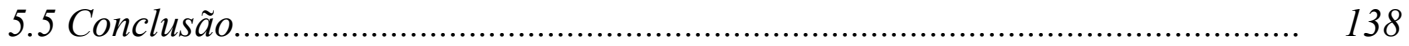

Referências bibliográficas.................................................................................. 139

6 APLICAÇÃO DA RADIAÇÃO EM MEMBRANAS POLIMÉRICAS ENXERTADAS E QUIMICAMENTE MODIFICADAS: PROPOSTA PARA REMEDIAÇÃO DO ALUMÍNIO EM ÁGUA POTÁVEL ................................. 143

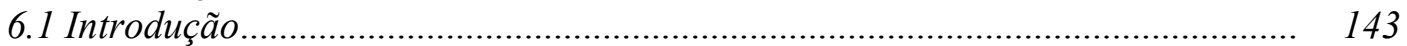

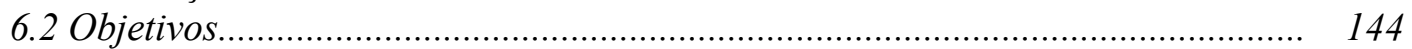

6.3 Materiais e Métodos........................................................................ 145

6.3.1 Preparo da membrana enxertada por radiação ionizante.............................. 145

6.3.2 Modificação química do polímero enxertado............................................... 145

6.3.3 Espectroscopia no Infravermelho por transformada de Fourrier (FTIR)....... 146

6.3.4 Análise morfológica da membrana.......................................................... 148

6.3.5 Testes de avaliação da membrana seletiva ao alumínio................................ 148

6.3.5.1 Sorção de alumínio em pH ideal e agentes interferentes............................ 148

6.3.5.2 Determinação da capacidade de absorção do alumínio.............................. 148

6.3.6 Teste da membrana seletiva ao alumínio em amostras de água natural........ 149

6.3.6.1 Coleta de amostras.............................................................................. 149

6.3.6.2 Pré-concentração dos íons alumínio (Al) utilizando a membrana seletiva 149

6.4 Resultados e discussão............................................................................. 149

6.4.1 Sintese da membrana seletiva ao alumínio..................................................... 149

6.4.2 Cinética da absorção do alumínio................................................................... 155

6.4.3 Teste de seletividade ao alumínio................................................................ 155

6.5. Conclusão............................................................................................ 157

Referências bibliográficas.............................................................................. 158

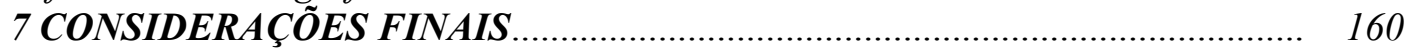

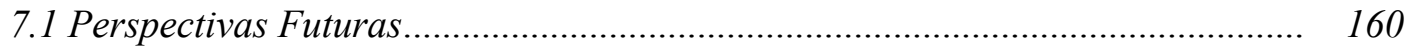

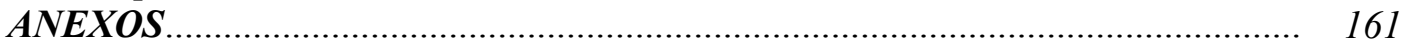




\section{LISTA DE TABELAS}

Página

TABELA 2.1 - Valores orientadores para solo e água subterrânea no Estado SP...

TABELA 3.1 - Faixas de valores para os três fatores de decisão..

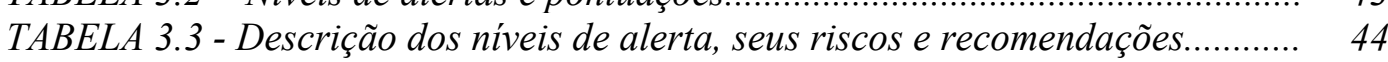

TABELA 3.4 - Concentração de metal total e dissolvidos ( $\mathrm{mg} / \mathrm{l})$ em amostras de águas superficiais: pontos de monitoramento na represa Billings, 2005-2007.........

TABELA 3.5 - Pontos de Amostragem - represa Billings (São Paulo, Brasil)............

TABELA 3.6 - Levantamento histórico dos valores máximos (VM) encontrado aos

11 metais ( $\mathrm{mg} / \mathrm{l})$ na água superficial da represa Billings.

TABELA 3.7 - Valor máximo anual do metal alumínio nos pontos de monitoramento da represa Billings, adaptado de anexos CETESB (2000-12)..........

TABELA 4.1. Condições das amostras e do processo de irradiação por feixe de elétrons.

TABELA 4.2 - Determinação da concentração de alumínio por ICP-OES nas soluções de ácido húmico nas concentrações de 1 ppm e 5 ppm contendo distintas concentrações de ions alumínio.

TABELA 4.3 - Determinação da concentração de alumínio por espectrometria UVvis nas soluções de ácido húmico nas concentrações de 1 ppm e 5 ppm contendo

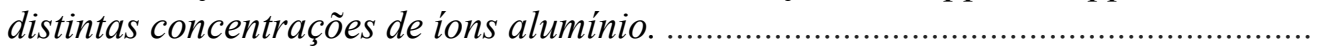
TABELA 5.1 - Resultados do alumínio total em água subterrânea (poços) período 2011-12 (adaptado ATIBORÉ, 2012)...

TABELA 5.2 - Resultados do manganês total em água subterrânea (poços) período 2011-12 (adaptado ATIBORÉ, 2012).

TABELA 5.3 - Resultados do ferro total em água subterrânea (poços) - período 2011-12 (adaptado ATIBORÉ, 2012)...

TABELA 5.4 - Denominações de cada bimestre de coleta de amostras.

TABELA 5.5 - Comparação da temperatura ambiente e da água dos poços, nascente e represa.

TABELA 5.6 - Resultados dos parâmetros físico-químicos das amostras de água na região em estudo.

TABELA 5.7 - Resultados obtidos pela técnica de ICP-OES em amostras irradiadas e não irradiadas.

TABELA 5.8 - Avaliação da concentração de COT nas amostras irradiadas e não irradiadas.

TABELA 5.9 - Resultados microbiológicos das amostras.

TABELA 5.10 - Resultado de metais em nascente da região da represa Billings (adaptado de ATIBORÉ, 2012).

TABELA 5.11- Resultado de alumínio total durante o ano 2011-12 nos poços e nascente (adaptado de ATIBORE, 2012)

TABELA 5.12a - PAMQUÁ: Resultado do poço 1.

TABELA 5.12b - PAMQUÁ: Resultado do poço $4 .$.

TABELA 5.12c-PAMQUÁ: Resultado do poço 8.

TABELA 5.12d-PAMQUÁ: Resultado do poço 9........

TABELA 5.12e - PAMQUÁ: Resultado da nascente.

TABELA 6.1. Processo de enxertia com estireno em amostras de PP.

TABELA 6.2 - Capacidade de captação de alumínio com amostras de membranas modificadas. 


\section{LISTA DE FIGURAS}

Página

FIGURA 2.1 - Principais Áreas de Drenagem da Billings.

FIGURA 2.2 - Principais rios formadores da bacia hidrográfica da Billings (adaptado de SMA, 1999)

FIGURA 2.3 - Tipos de formações aquíferas (CPRM, 1998).

FIGURA 2.4 - Poço tubular ou artesiano. Possui alguns centímetros de abertura (no máximo $50 \mathrm{~cm}$ ) e é revestido com canos de ferro ou de plástico (PVC) (CPRM, 1998).

FIGURA 2.5. a) Ciclo da água subterrânea e b) tipos de poços.

FIGURA 2.6 - Percentual do uso de água subterrânea em regiões no Brasil (SAMPAIO, 2012).

FIGURA 2.7 - FIGURA 2.7 - Localização das estações meteorológicas e

hidrológicas na região da represa Billings (PROAM, 2009)...

FIGURA 3.1 - Gráfico com as porcentagens de não conformidades versus histórico dos resultados, adaptado dos relatórios anuais disponíveis pela CETESB (2000-2012)

FIGURA 3.2 - Gráfico com os resultados históricos da regressão de contaminação por alumínio.

FIGURA 4.1. Preparo de amostras em frascos para o processo por irradiação gama.

FIGURA 4.2. Preparo de amostras em refratários para o processo de irradiação por feixe de elétrons.

FIGURA 4.3. Desenho esquemático (corte longitudinal) da disposição das amostras no dispositivo de irradiação Gammacell-220.

FIGURA 4.4. Amostras sob o processo de irradiação no acelerador de elétrons Dynamitron ${ }^{\circledR}$......

FIGURA 4.5. a) Curva de calibração da espectrofotometria UV-vis das amostras não irradiadas e b) Concentração relativa de ácido húmico calculada a partir da calibração em a) em função da dose de radiação gama.

FIGURA 4.6. a) Efeito da radiação gama em distintos volumes de amostra e b) resultado do COT em função da dose absorvida nas amostras com AH sem aditivos e com os aditivos $\mathrm{H}_{2} \mathrm{O}_{2}$ e $\mathrm{H}_{2} \mathrm{SO}_{4}$ na concentração de $1 \%$.

FIGURA 4.7. Resultado do COT sobre o efeito da radiação gama em soluções de ácido húmico com $1 \%$ de $\mathrm{H}_{2} \mathrm{SO}_{4}$ e com $1 \%$ de $\mathrm{H}_{2} \mathrm{O}_{2}$ irradiados em $5 \mathrm{kGy}$ e $10 \mathrm{kGy}$. FIGURA 4.8. Teor de CI das soluções de AH contendo $1 \%$ de $\mathrm{H}_{2} \mathrm{O}_{2}$ irradiadas em $10 k$ Gy comparado ao das soluções de AH não irradiadas e sem aditivos.

FIGURA 4.9. Espectros de UV-vis de soluções aquosas de ácido húmico. a) todas as concentrações estudadas e b) Detalhe dos espectros das concentrações mais baixas.

FIGURA 4.10. Espectros de UV-vis das soluções aquosas de ácido húmico após o processo de irradiação gama a) $5 \mathrm{kGy}$ e b) $60 \mathrm{kGy}$.

FIGURA 4.11. Espectros de UV-vis das soluções aquosas de ácido húmico após o processo de irradiação por feixe de elétrons na taxa de dose de 2,2 kGy/s e nas seguintes doses absorvidas: a) $5 k G y$, b) $5 k G y$-detalhes em concentrações mais baixas e c) $60 k G y$...

FIGURA 4.12 - Espectros de UV-vis das soluções aquosas de ácido húmico com o aditivo ácido sulfúrico $\left(\mathrm{H}_{2} \mathrm{SO}_{4}\right)$. a) Amostras não irradiadas. Amostras irradiadas 
sob feixe de elétrons na taxa de dose de 2,2 kGy/s e doses de: b) $10 \mathrm{kGy} e$ c) $60 \mathrm{kGy}$

FIGURA 4.13 - Espectros de UV-vis das soluções aquosas de ácido húmico com o aditivo $\mathrm{H}_{2} \mathrm{SO}_{4}$. Processo de irradiação gama: a) dose absorvida de $5 \mathrm{kGy}$ e b) dose absorvida de $60 \mathrm{kGy}$.

FIGURA 4.14. Espectros de UV-vis das soluções aquosas de ácido húmico com água oxigenada $\left(\mathrm{H}_{2} \mathrm{O}_{2}\right)$. a) Amostras não irradiadas; b) solução de 5 ppm de $\mathrm{AH}$ em várias situações: com aditivo e não irradiado, com aditivo e irradiado sob raios gama nas doses $5 \mathrm{kGy}$ e $60 \mathrm{kGy}$ e sob feixe de elétrons na dose de $5 k G y$ e taxa de dose 2,2 kGy/s; comparação com os espectros da solução de AH 5 ppm sem aditivo e não irradiada e com os brancos não irradiados (água destilada com e sem esse aditivo) e irradiado (água destilada com aditivo irradiado sob raios gama na dose de $60 \mathrm{kGy}$ )

FIGURA 4.15. Espectros de UV-vis das soluções aquosas de ácido húmico com o aditivo ácido nítrico $\left(\mathrm{HNO}_{3}\right)$ não irradiadas.....

FIGURA 4.16. Espectros de UV-vis das soluções aquosas de ácido húmico nas concentrações 1 ppm e 5 ppm sem íons alumínio e com íons alumínio, comparados com o espectro de água destilada.

FIGURA 4.17. Espectros de UV-vis das soluções aquosas de ácido húmico nas concentrações 1 ppm e 5 ppm misturados à íons alumínio nas concentrações: 0,5 ppm, 1 ppm, 2,5 ppm e 5 ppm. Comparação com o espectro da água destilada........ FIGURA 4.18. Espectros de UV-vis das soluções aquosas de ácido húmico nas concentrações 1 ppm e 5 ppm misturados à íons alumínio na concentração de 5 ppm comparados aos espectros das mesmas soluções irradiadas por: a) feixe de elétrons (dose: $5 \mathrm{kGy}$ e taxa de dose: 2,2 kGy/s) e b) raios gama (dose: $20 \mathrm{kGy}$ )...... FIGURA 5.1- Resultado do comprimento de onda (nm) e absorbância da amostra de água da nascente.

FIGURA 5.2-Resultado do comprimento de onda (nm) e absorbância da amostra de água de poço (P9).

FIGURA 6.1. Fluxograma do polímero seletivo para a espécie química alumínio.... FIGURA 6.2. Espectros do PP enxertado em cada etapa de modificação química... FIGURA 6.3. Micrografia eletrônica de varredura da amostra de PP enxertada com estireno com elevado grau de enxertia (PP-1)...

FIGURA 6.4. Micrografia eletrônica de varredura da amostra de PP enxertada com estireno com elevado grau de enxertia e quimicamente modificada (PP-1)....... FIGURA 6.5. Micrografia eletrônica de varredura da amostra de PP enxertada com estireno em baixo grau de enxertia e quimicamente modificada (PP-2)............ FIGURA 6.6. (1) PP enxertado com estireno por irradiação (alto grau de enxertia); (2) PP enxertado (alto grau de enxertia) e modificado quimicamente (baixo rendimento no processo químico); (3) PP enxertado (alto grau de enxertia) e com alto rendimento na etapa de modificação química; (4) PP enxertado (baixo grau de enxertia) e com alto rendimento na etapa de modificação química.

FIGURA 6.7. Remoção de aluminio a partir de soluções líquidas em distintos valores de $\mathrm{pH}$ em função do tempo de sorção.

FIGURA 6.8. Efeito da sorção de alumínio na solução contendo como interferentes os ions $\mathrm{Zn}^{2+}$ e $\mathrm{Cd}^{2+}$. 


\section{LISTA DE SIGLAS}

\begin{tabular}{|c|c|}
\hline AAS & Espectrometria por Absorção Atômica \\
\hline ABI & Associação Brasileira de Imprensa \\
\hline APA & Áreas de Proteção Ambiental \\
\hline APHA & American Public Health Association \\
\hline APRM & Área de Proteção e Recuperação de Mananciais \\
\hline ATIBORÉ & Associação de Turismo da Ilha do Bororé \\
\hline CEAGESP & Companhia Entreposto de Armazéns Gerais do Estado de São Paulo \\
\hline CEASA & Centrais de Abastecimento \\
\hline CEDEFES & Centro de Documentação Eloy Ferreira da Silva \\
\hline CETESB & Companhia de Tecnologia de Saneamento Ambiental \\
\hline $\mathrm{CNRH}$ & Conselho Nacional de Recursos Hídricos \\
\hline CONAMA & Conselho Nacional do Meio Ambiente \\
\hline CONSEMA & Conselho Estadual do Meio Ambiente \\
\hline COT & Carbono Orgânico Total \\
\hline CTC & Capacidade de Troca Catiônica \\
\hline DAEE & Departamento de Águas e Energia Elétrica \\
\hline ELETROBRAS & Centrais Elétricas Brasileiras S.A. \\
\hline EMAE & Empresa Metropolitana de Águas e Energia S.A \\
\hline FEMA & Fundo Especial do Meio Ambiente \\
\hline FTIR & Espectroscopia no Infravermelho \\
\hline FUNAI & Fundação Nacional do Índio \\
\hline FUNASA & Fundação Nacional da Saúde \\
\hline GEGRAN & Grupo Executivo da Grande São Paulo \\
\hline IBGE & Instituto Brasileiro de Geografia e Estatística \\
\hline ICP-MS & Espectrometria por Massa Atômica de Absorção por Plasma \\
\hline \multirow[t]{2}{*}{ ICP-OES } & Espectrometria de Emissão Atômica por Plasma Acoplado \\
\hline & Indutivamente \\
\hline IHSS & Sociedade Internacional de Substâncias Húmicas \\
\hline \multirow[t]{2}{*}{ IP/SAA } & Instituto de Pesca da Secretária da Agricultura Abastecimento do \\
\hline & Estado de São Paulo \\
\hline IPEN & Instituto de Pesquisas Energéticas e Nucleares \\
\hline
\end{tabular}




\begin{tabular}{|c|c|}
\hline MON & Matéria Orgânica Natural \\
\hline $\mathrm{NCA}$ & Conformidade Acumulado \\
\hline $\mathrm{OAB}$ & Ordem dos Advogados do Brasil \\
\hline ONG & Organizações Não-Governamental \\
\hline PAMQUÁ & Programa Auxiliar de Monitoramento da Qualidade de Águas \\
\hline PDPA & Plano de Desenvolvimento e Proteção Ambiental \\
\hline PMA & Plano Metropolitano de Água \\
\hline POA & Processos de Oxidação Avançado \\
\hline PP & Polipropileno \\
\hline PROAM & Instituto Brasileiro de Proteção Ambiental \\
\hline PVC & Polímeros Cloreto de Polivinila \\
\hline $\mathrm{RMN}$ & Espectroscopia de Ressonancia Magnetica Nuclear \\
\hline RMSP & Região Metropolitana de São Paulo \\
\hline SABESP & Companhia de Saneamento Básico do Estado de São Paulo \\
\hline SBPC & Sociedade Brasileira para o Progresso da Ciência \\
\hline SEE & Secretaria de Estado de Energia \\
\hline SES & Secretaria de Estado da Saúde \\
\hline $\mathrm{SH}$ & Substâncias Húmicas \\
\hline SMA & Secretaria do Meio Ambiente \\
\hline SNIS & Sistema Nacional de Informações sobre Saneamento Básico \\
\hline SRHSO & Secretaria de Estado de Recursos Hídricos, Saneamento e Obras \\
\hline SSI & Subsistema de Saúde Indígena \\
\hline SUS & Sistema Único de Saúde \\
\hline SVMA & Secretária Municipal do Verde e Meio Ambiente \\
\hline UGRHI & Unidade de Gerenciamento de Recursos Hídricos \\
\hline UHE & Usina Hidrelétrica \\
\hline USEPA & United States Environmental Agency \\
\hline UV-vis & Espectroscopia de radiação na região do ultravioleta-visível \\
\hline VI & Valor de Intervenção \\
\hline VM & Valores Máximos \\
\hline VMP & Valor Máximo Permitido \\
\hline VP & Valor de Prevenção \\
\hline VRQ & Valor de Referência de Qualidade \\
\hline
\end{tabular}




\section{INTRODUÇÃO}

A utilização da tecnologia nuclear nas ciências metrológica, química e ambiental constitui uma ferramenta para o incremento do conhecimento. Embora essa tecnologia tenha como primeiro impacto uma imagem destrutiva, propósitos pacíficos em várias áreas do conhecimento humano tem sido evidenciados, trazendo muitos benefícios e contribuindo para a melhoria da qualidade de vida.

$\mathrm{O}$ estudo da energia nuclear tem sido importante para a humanidade neste século XXI, uma vez que se discute a popularização deste tipo de energia como aquela que não libera subprodutos poluentes ao ambiente se comparada à energia proveniente de combustível fóssil. Sendo assim, o seu papel como instrumento pacífico que beneficia diversas ciências precisa ser difundido.

$\mathrm{Na}$ área ambiental, o uso das técnicas nucleares tem permitido determinar a origem e as quantidades de poluentes orgânicos e inorgânicos com grande eficiência, seja na água, no ar, no solo ou no subsolo com rapidez e baixo custo (SAIKI et. al, 2002; MOREIRA et. al, 2013). As técnicas nucleares também podem eliminar poluentes, já que a radiação de alta energia faz parte dos métodos de oxidação avançada, onde a partir do uso de fontes de radiação ionizante os efluentes industriais e esgotos domésticos, que são problemáticos contaminantes dos recursos hídricos, podem ser degradados mais rapidamente, sendo esse processo importante à proteção do meio ambiente (DUARTE et al, 2002; DUARTE et. al, 2004). O mesmo processo pode ser aplicado na otimização de diagnósticos químico analíticos, utilizando esse tipo de processo no preparo amostral, objetivando uma mineralização ou a quebra radiolítica de compostos orgânicos numa velocidade incomparável, sem contaminação e sem geração de efluente químico laboratorial (MEEROFF et. al, 2004; FROSE et. al, 2011; VANCONCELLOS et. al, 1999; VANCONCELLOS et. al, 2001).

A aplicação da radiação ionizante na criação de novos produtos tem sido um tema bem explorado na literatura (FERREIRA et al., 2010; MOURA et al., 2011; MOURA et al., 2012; BAZANTE-YAMAGUISHI et al., 2013) uma vez que se pode modificar a estrutura molecular de substratos base pela radiação ionizante.

Nestes termos, verifica-se que os polímeros são suscetíveis a esse tipo de transformação; a modificação de um dado tipo de polímero para um material com outro grau de resistência mecânica e/ou com propriedades físico-químicas mais específicas é um 
desafio, uma vez que os polímeros estão cada vez mais em nosso cotidiano e se tornaram essenciais para a vida moderna (BHATTACHARYA, 2000).

O presente trabalho lança mão da tecnologia nuclear como ferramenta inovadora tanto no pré-tratamento amostral para o diagnóstico da espécie química alumínio em água potável, como também na criação de um novo material destinado à remediação de águas contaminadas por alumínio.

Sendo assim, este trabalho está apresentado em sete capítulos. O primeiro capítulo apresenta a introdução geral mostrando brevemente o tema e as bases teóricoexperimentais dessa pesquisa, os objetivos e como está apresentada a tese. No segundo capítulo foi descrita a Caracterização da Área para a contextualização do desenvolvimento desse trabalho. No terceiro capítulo é apresentado o programa $P A M Q U A^{\circledR}$, criado para delinear dados de contaminação histórica, cuja sua aplicação, neste caso, foi ao estudo da especiação química do alumínio a partir de dados disponíveis em domínio público sobre o monitoramento da qualidade das águas do reservatório Billings, a diretriz dada ao estudo, especialmente em relação à presença de metais em águas subterrâneas (poços) e às normas de potabilidade. No quarto capítulo: Degradação Radiolítica do Ácido Húmico: Estudo da Proposta de Pré-Tratamento de Amostras de Águas de Mananciais, é abordado o tema da radiação ionizante e sua aplicação no tratamento de amostras de água e obtenção dos resultados analíticos, demonstrado através de experimentos com amostras de ácido húmico padrão, um composto orgânico normalmente encontrado em águas subterrâneas e que complexa facilmente os íons alumínio. No quinto capítulo, Radiação Ionizante como Otimização na Detecção de Alumínio em Amostras de Água Potável, as doses e taxas anteriormente estudadas são aplicadas às amostras de água dos poços escolhidos para o estudo, com o propósito de sua aplicação em métodos quantitativos clássicos e mais econômicos como espectrofotometria UV-vis, além de correlacioná-los com o método de ICP-OES na determinação do alumínio nessas águas e a aplicação da ferramenta estatística PAMQUÁ ${ }^{\circledR}$. O penúltimo capítulo - Aplicação da Radiação em Membranas Poliméricas Enxertadas e Quimicamente Modificada: Proposta para Minimização do Alumínio em Água Potável - mostra a metodologia da síntese da membrana seletiva por radiação ionizante para ser aplicada na remediação do alumínio nas águas de mananciais. O último capítulo - Considerações Finais - apresenta uma síntese geral dos principais atributos desse trabalho e as perspectivas futuras para a sua continuidade a partir dos estudos apresentados nessa tese. 


\subsection{Objetivos}

Este trabalho tem como objetivos gerais:

1) Investigar a contaminação por alumínio nas águas subterrâneas da região do manancial Billings;

2) Aplicar o processo de irradiação ionizante na mineralização de amostras de água natural como etapa de pré-tratamento para a determinação analítica da espécie química alumínio encontrada em amostras de água provenientes de poços de captação localizados na região da represa Billings;

3) Sintetizar um tipo de membrana polimérica modificada por radiação com a finalidade de remediação específica do alumínio nestas amostras de água. 


\section{REFERÊNCIAS BIBLIOGRÁFICAS}

BAZANTE-YAMAGUISHI, R.; GERALDO, A.B.C.; MOURA, E.; MANZOLI, J.E. Radiation-grafted, chemically modified membranes part I - Synthesis of as elective aluminum material. Radiation Physics and Chemistry. 10.1016/j.radphyschem. 2013.06.008i, pp. 10.1016, (2013). Disponível em: <http://www.sciencedirect.com/ science/article/pii/S0969806X13003794>

BHAtTACHARYA, A. Radiation and industrial polymers. Prog. Polym. Sci. 25 (3), 371$401,2000$.

DUARTE, C.L.; MORI, M.N., BAUMGARTNER. J.B. Tratamento de Óleo de Corte pelo Processo de Oxidação Avançada por Radiação Ionizante. ICTR 2004 - Congresso Brasileiro de Ciência e Tecnologia em Resíduos e Desenvolvimento Sustentável Costão do Santinho - Florianópolis - Santa Catarina ICTR. 9p. 2004.

DUARTE, C.L.; SAMPA, M.H.O.; RELA, P.R.; OIKAWA, H.; SILVEIRA, C.G.; AZEVEDO, A.L.. Advanced Oxidation Process by Electron Beam Irradiation Induced Decomposition of Pollutants in Industrial Effluents. Radiat. Phys. Chem., v.63, p.647-651, 2002.

FERREIRA, H. P.; SOUZA, C. P. de; PARRA, D. F.; LUGÃO, A. B. Enxertia de estireno em filmes de Poli (Fluoreto de Vinilideno) induzida por radiação Gama. In: $19^{\circ}$ Congresso Brasileiro de Engenharia e Ciência dos Materiais - CBECiMat, 21 a 25 de novembro de 2010, Campos do Jordão, SP, Brasil, 2010.

FROSE, C.A.P.; MOURA, E.; BAZANTE-YAMAGUISHI, R..; SOMESSARI, E.S.R.; SILVEIRA, C.G.; LEME, E.; GERALDO, A.B.C.; MANZOLI, J.E. Polymerization of tilapia (Oreochromis niloticus) skin by electron beam irradiation. International Nuclear Atlantic Conference; Meeting on Nuclear Applications, 10th; Meeting on Reactor Physics and Thermal Hydraulics, 17th; Meeting on Nuclear Industry, 2st - Belo Horizonte, MG, oct. 2011. Disponível em: <http://pintassilgo2.ipen.br/biblioteca/2011/inac/17180> Acesso em: 20 mar. 12.

MEEROFF, D.E.; WAITE, T.D; KAZUMI, J.; KURUCZ, C.N. Radiation-Assisted Process Enhancement in Wastewater Treatment. Journal of Environmental Engineering, v. 130, n. 2, feb. 2004. Disponível em: <http://www.aseanenvironment.info/ Abstract/41013608.pdf> Acesso em: 05 jan. 12.

MOREIRA, E.G.; MATHOR, M.B.; VASCONCELLOS, M.B.A. Gamma Ray Sterilization Study on a Perna perna Mussel Reference Material. Ecotoxicol. Environ. Contam., v. 8, n. 1, 2013, 149-152 doi: 10.5132/eec.2013.01.023 
MOURA, E.; MANZOLI, J. E.; GERALDO, A.B.C. Effects of solvent polarity on mutual styrene grafting onto polypropylene by electron beam irradiation. Radiation Physics and Chemistry. v.81, pp. 1309-1313, 2012. Disponível em: $\leq \mathrm{http}: / /$ www.sciencedirect.com/science/article/pii/S0969806X12000643>

MOURA, E.; SOMESSARI, E.; SILVEIRA, C.; PAES, H.; SOUZA, C.; FERNANDES, W.; MANZOLI, J.; GERALDO, A. Influence of physical parameters on mutual polymer grafting by electron beam irradiation. Radiation Physics and Chemistry, v.80, pp. 175181, 2011. Disponível em: $\leq \mathrm{http}: / / \mathrm{www}$. sciencedirect.com/science/article/pii/ $\underline{\text { S0969806X1000318X> }}$

SAIKI, M., DA SILVA, M.C., FULFARO, R., VASCONCELLOS, M.B.A. Study on instrumental neutron activation analysis of aluminium in geological and biological reference materials. Journal of Trace and Microprobe Techniques, 20 (4), pp. 517-525, 2002.

VANCONCELLOS, M.B.A., PALETTI, G., CATHARINO, M.G.M., SAIKI, M., FÁVARO, D.I.T BARUZZI, R., RODRIGUES, D.A., BYRNE, A.R., FORTI, M.C. Studies on mercury exposure of some Brazilian Populational groups living in the amazonic region by Means of hair analysis. 2001. Disponível em: $<$ http://www.chem.unep.ch/mercury/2001-gov-sub/sub68govatt1.pdf $>$ Acesso em: 10 mar. 12 .

VANCONCELLOS, M.B.A., PALETTI, G., SAIKI, M., FÁVARO, D.I.T., CATHARINO, M.G.M., BARUZZI, R., RODRIGUES, D.A., BYRNE, A.R., FORTI, M.C. Biomonitoring of Total Mercury and Methylmercury Contamination of Population Groups Living in the Xingu Park Indian Reservation and in the State of Amapá, Brazil, by Means of Hair Analysis. In "Proc. 5th International Conference on Mercury as a Global Pollutant", 407, Rio de Janeiro (abstract), 1999. 


\section{CARACTERIZAÇÃO DA ÁREA}

\subsection{Introdução}

Dois terços do nosso planeta são formados por água e somente $0,008 \%$ é água potável. A crescente escassez de água potável no planeta é o provável problema ambiental do século XXI. Nos últimos 50 anos, a extração anual de água doce de lagos, rios e aqüíferos triplicou e os crescimentos populacional e econômico continuam a incrementar a necessidade tanto por água quanto por serviços relacionados a ela (TUNDISI, 2003), o que faz dos recursos hídricos uma questão não só ecológica como também política, econômica e social (MARIANI, 2006).

O desafio da água no planeta, de acordo com a Governança Global em Recursos Hídricos é implementar prioridades nos continentes: na África, planos de saneamento básico; na Ásia, aumentar o acesso a água e ao saneamento básico; na Europa, adotar boas práticas em cooperação transfronteiriças e nas Américas aumentar acesso à água para todos (SAMPAIO, 2012).

A gestão da qualidade dos mananciais, que inclui as águas superficiais e subterrâneas, foi tardiamente implantada no Brasil. Grande parte da população tem pouco ou nenhum acesso à informação sobre a qualidade das águas ou sequer tem meios para avaliar a real condição da água que é parte da sua saúde e do seu cotidiano. Os esforços governamentais na tentativa de despoluir rios, controlar enchentes e resolver problemas de saneamento básico, mesmo nas grandes cidades, ainda continuam sem soluções.

Reservatórios hídricos que, inicialmente, não foram projetados para abastecimento público, mas que são aproveitados para este fim, merecem atenção especial, pois muitos estão contaminados e precisam de monitoramento constante pelos órgãos responsáveis e/ou fiscalizadores pelo seu uso, além da contrapartida da sociedade perante as questões de sua preservação para garantir a potabilidade de suas águas.

Os resultados da qualidade da água na forma de relatórios públicos periódicos governamentais (ou privados) devem ser observados pela sociedade e exigidos que os valores dos elementos dissolvidos não ultrapassem o valor máximo permitido (VMP) a cada parâmetro monitorado, uma vez que a água é fonte direta de qualidade de vida e possível potencial de risco à saúde da população que a utiliza. 
Segundo o IBGE, em 2008, cerca de 309 pessoas a cada 100 mil eram internadas em decorrência de doenças de origem hídrica (dengue, diarréia e leptospirose, entre outras doenças virais), sendo os estados do Norte e Nordeste brasileiros os mais afetados. Atualmente a população brasileira se aproxima de 200 milhões de habitantes, porém mais de $56 \%$ um pouco mais que metade do total dos domicílios brasileiros não tem acesso à coleta e ao tratamento de esgoto (WORLD BANK, 2013).

Segundo a base de dados SNIS, publicado pelo Ministério das Cidades, o índice médio em população atendida com coleta de esgoto é de 59,1\% (TRATA BRASIL, 2010). Esses índices são dados pelos números da RMSP, a qual reúne 34 municípios e possui a maior população do Brasil e nas Américas - cerca de 20,7 milhões de habitantes sendo 11,8 milhões de habitantes somente na cidade de São Paulo, a sexta maior metrópole do mundo (IBGE, 2013).

Dos 34 municípios da RMSP, 16 não tratam seu esgoto que é lançado em córregos e rios que desaguam no principal rio do estado que é o Tietê (BRANCATELLI \& FORTES, 2011). No entanto, as águas deste rio se comunicam com o extremo sul da cidade, onde se encontram duas Áreas de Proteção Ambiental (APA), a Capivari-Monos e Bororé-Colônia. As APAs são Unidades de Conservação de Uso Sustentável que funcionam em parceria com a comunidade. Essas duas áreas são importantes ecossistemas que juntos, representam 1/5 do território municipal (REITER et al., 2012).

Nessas áreas protegidas da represa Billings, o uso dos recursos naturais não é proibido, mas regulado, sendo o seu instrumento legal o Plano de Manejo e o Zoneamento Ambiental (REITER et al., 2012). O referido plano restringe, ou muitas vezes não abrange áreas que deveriam contemplar a infraestrutura e saneamento básico mediante aos recursos hídricos disponíveis. Isto acaba excluindo populações que possuem o direito consuetudinário $^{1}$, como por exemplo, as comunidades indígenas e de pescadores, já que são comunidades detentoras de um conhecimento historicamente adquirido através do contato direto com a natureza possuindo normas perfeitamente lógicas e adaptadas ao meio, como citado por Thompson (2002) e Chamy (2004) - não se devem excluir comunidades, onde as regras que as legitimam são tão rigorosas como as do direito codificado, mesmo sendo reproduzidas ao longo de gerações na "atmosfera lentamente diversificada dos costumes".

1 Direito consuetudinário (CHAMMY, 2013) é a legitima prática e uso, alicerçando-se nos valores significados, compartilhados e nos costumes que se alteram no tempo e no espaço. 
A revisão da literatura neste capítulo mostra algumas observações sobre dados demográficos e de saneamento básico (principalmente o de tratamento de águas), contextualizados pela política estadual de recursos e leis de proteção ao manancial e normatizações de qualidade da água, relacionando os fatos sobre a contaminação por metais da represa Billings.

\subsection{O maior manancial do Estado de São Paulo}

No começo do século XX, a cidade de São Paulo possuía apenas uma usina hidrelétrica para geração de energia, localizada na região de Santana do Parnaíba (atualmente conhecida como usina elevatória de Edgard de Souza) e a população ultrapassava aos 240 mil habitantes. Devido ao baixo desempenho da usina nos períodos de estiagem associados ao aumento constante do consumo, houve a necessidade de aumentar a vazão de água para atender a demanda de geração de energia.

Em 1906, foi construída a barragem da represa Guarapiranga, suprindo o rio Guarapiranga que se juntava ao rio Grande, para formar o rio Pinheiros que desaguava no rio Tietê (em condição natural), atendendo à usina neste período (NUCCI, 1993). Entretanto, verificou-se que esta medida fora insuficiente surgindo a necessidade de construir uma nova barragem. Em 1927, após a construção da Barragem de Pedreira, no curso do rio Grande, também denominado rio Jurubatuba, nasce a represa Billings.

Com a represa foi possível regularizar o fluxo das águas, inicialmente para gerar energia em Santana do Parnaíba. Porém, o objetivo principal de sua construção estava em abastecer uma nova usina hidrelétrica que seria construída em Cubatão, a UHE Henry Borden, e suprir a carência energética devido ao acelerado crescimento da cidade de São Paulo (EMAE, 2008). Através da construção de uma outra represa, chamada rio das Pedras, parte da água da Billings gerou energia para a cidade de Cubatão, aproveitando o desnível da Serra do Mar (JESUS, 2006). A usina, atualmente está à cargo da concessionária EMAE. As águas dos rios Pinheiros e Tietê foram revertidas ao reservatório Billings, uma vez que o volume de água anterior não era o suficiente para alimentar as turbinas, conseqüentemente, parte do curso d'água da água da bacia hidrográfica do Alto Tietê sofreu alteração para a vertente oceânica (TRINDADE, 1988).

No final da década de 40, houve a reversão do rio Pinheiros, através da construção das Usinas Elevatórias de Pedreira e Traição, tornando o rio Tietê seu afluente, de modo que a vazão de água fosse satisfatória e o aumento da capacidade de geração da 
energia elétrica, além do atendimento de outras necessidades, como as ações de controle das enchentes fossem solucionados (CETESB, 1993). De fato, grande parte das águas da região metropolitana não voltava mais para a região, nem para o Médio e Baixo Tietê e, temporariamente, teríamos a solução energética, entretanto, não imaginariamos que essa reversão do rio desencadearia problemas sérios de contaminação ambiental, principalmente dado pelo lançamento de esgoto indústrial e doméstico diretamente a um reservatório que no futuro serveria para o abastecimento da cidade - o reservatório Billings.

Nucci (1993) relata que todas as mudanças dos cursos d'água citados, foram devido à baixa reserva de água da represa Guarapiranga e a derivação das águas da Billings, que com o crescimento acelerado da industrialização e o aumento da população, conflitos de gestão já estariam por vir.

Após o advento da Billings e a posterior colocação de peixes, iniciada a partir de 1948 pelo antigo Serviço de Piscicultura da Ligth (ROCHA et al., 1985), começou a pesca sistematizada, chegando a represa, vinte anos mais tarde, a contribuir com 215,7 toneladas do pescado que entraram na CEAGESP, antigo CEASA.

Para sistematizar a ação pública no aproveitamento múltiplo dos recursos hídricos criou-se o DAEE. Mas a questão principal seria ainda discutida: a quantidade pela gestão energética dos recursos e a qualidade das águas devido ao uso intenso das águas da bacia do Alto Tietê como receptor de esgoto bruto praticamente sem nenhum tratamento (NUCCI, 1993).

Em 1958, inicio da captação da água no braço rio Grande, a represa agregou mais uma função: a de abastecimento da região industrial do Estado de São Paulo - a região do ABC - Santo André (A), São Bernardo do Campo (B) e São Caetano do Sul (C). Nos anos 60 criou-se o primeiro grande plano de aproveitamento múltiplo das águas e o GEGRAN para propor soluções aos problemas, integrando seus usos multiplos dos recursos hídricos (SABESP, 2008).

No início da década de 70, a alta poluição dos rios Tietê e Pinheiros e o aparecimento da primeira floração de algas, a atividade da colocação de peixes na represa foi interrompida, de modo que a produção pesqueira acabou por ser praticada em pequena escala (ROCHA, et al., 1985). Nessa época houve um quase absoluto predomínio da gestão em função do uso de geração hidrelétrica. Assim, pela primeira vez, começou a se 
contestar esse predomínio e afirmar que a água não tinha que ser exclusivamente da ordem energética (SÃO PAULO, 1993).

Com o objetivo de evitar a degradação da bacia hidrográfica, em 1975 e 1976 foram criadas as Leis de Proteção dos Mananciais - 898/75 e 1.172/76. Em 1979 foi elaborado um Plano Diretor de Mineração para a Região Metropolitana de São Paulo cujo objetivo maior era inserir a atividade mineradora no processo de planejamento metropolitano com diretrizes que deveriam ser seguidas pelos municípios. A partir dos levantamentos realizados junto aos órgãos governamentais, foram identificados 90 processos de mineração cadastrados dentro da área da bacia hidrográfica da Billings. Embora apenas sete estejam licenciados, abrangendo uma área total de 2.079,01 ha, outros 13.076,38 ha estão sendo requeridos para pesquisa. Sendo assim, caso todos os processos atualmente em tramitação cheguem à etapa de concessão de lavra ou regime de licenciamento, a bacia hidrográfica da Billings terá $26,16 \%$ de sua área sob algum tipo de exploração mineral. Em 1982, com a construção da Barragem Anchieta houve a separação das águas do rio Grande para garantir a qualidade das águas ao abastecimento público.

No ano de 1989, o lançamento dos rios Tietê e Pinheiros fica proibido e em 1993 o CONSEMA restringe definitivamente o bombeamento das águas poluídas, com excessão em caso de enchentes na cidade de São Paulo. Em 2000, devido a escassez de água no reservatório Guarapiranga, a transposição das águas do trecho Taquacetuba da represa Billings foi necessária.

A Billings foi considerada uma represa urbana por localizar-se em uma área de grande adensamento populacional. Suas águas são utilizadas como lazer, recreação, pesca esportiva, irrigação para agricultura, abastecimento, receptor de efluentes, sistema regulador da vazão do Alto Tietê, contenção de cheias (ARAUJO et al., 2006), além da atividade de pesca artesanal, bastante antiga no reservatório (MINTE-VERA, 1997).

O conceito de eficiência econômica passou de um conceito de eficiência produtiva para algo mais amplo, como benefícios ligados não à produção e sim à satisfação das demandas comuns à todos (NUCCI, 1993). Por isso, de acordo com Ranzani de Paiva (2006) o conceito atualmente em voga é o de "usos múltiplos" da represa.

$\mathrm{O}$ reservatório Billings situa-se na porção sudeste da RMSP próximo às escarpas da Serra do Mar; sendo o maior reservatório de água da Região Metropolitana de São Paulo. Seu espelho d'água possui 10.814,20 hectares, correspondendo a $18 \%$ da área 
total de sua bacia hidrográfica, que ocupa um território de $58.280,32$ hectares $\left(582,8 \mathrm{~km}^{2}\right)$. Faz limite à oeste com a bacia hidrográfica da represa Guarapiranga e ao sul, com a Serra do Mar. Sua área de drenagem (FIG. 2.1) abrange integralmente o município de Rio Grande da Serra e parcialmente os municípios de Diadema, Ribeirão Pires, Santo André, São Bernardo do Campo e São Paulo, fazendo parte da bacia hidrográfica do Alto Tietê e do sistema de monitoramento da qualidade das águas, caracterizada como a sexta UGRHI da CETESB.

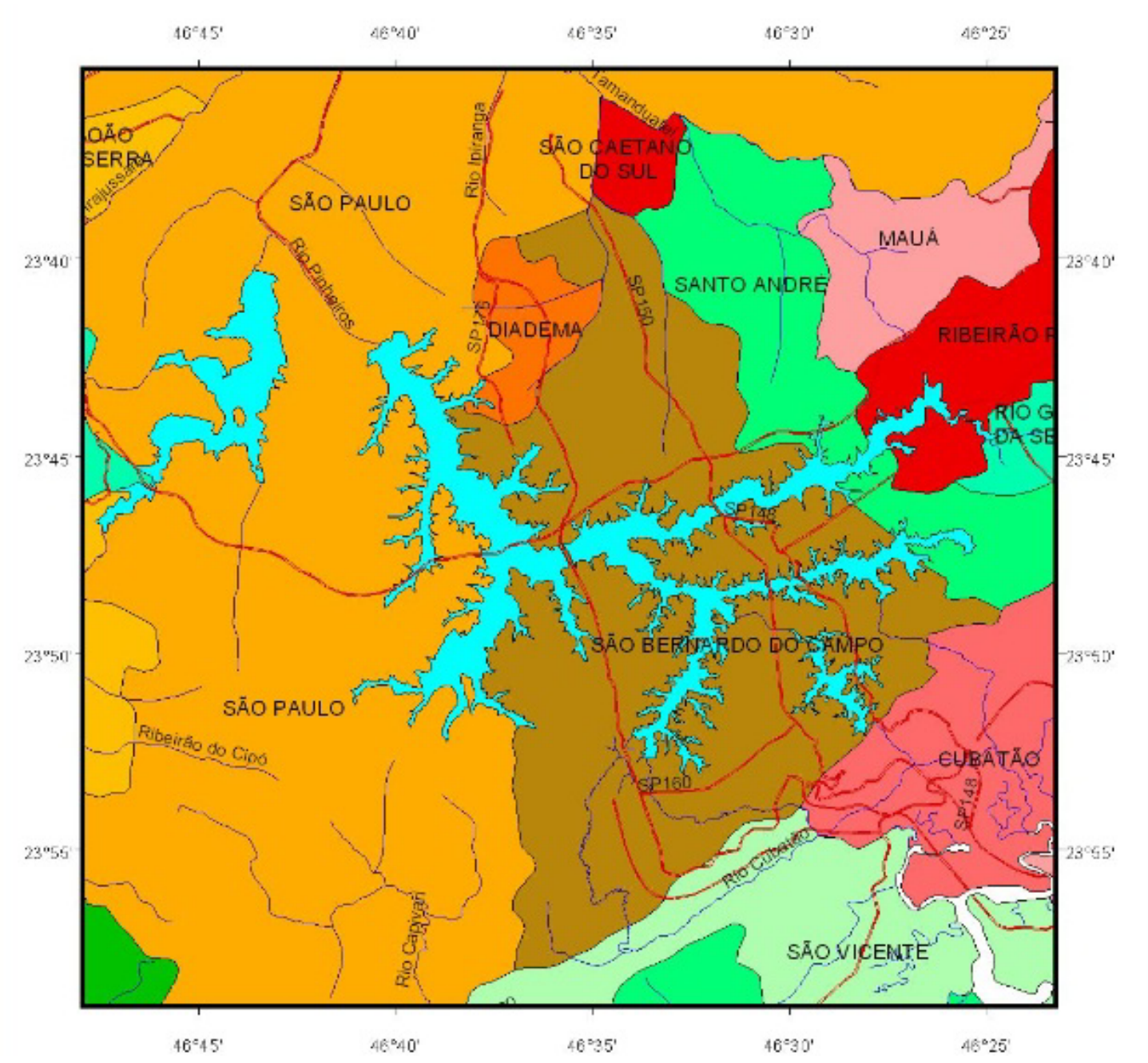

FIGURA 2.1 - Principais áreas de drenagem da Billings e municípios adjacentes.

A maior parte de suas nascentes localiza-se na porção sul e leste da bacia, próximas ao reverso das escarpas da Serra do Mar, em altitudes máximas em torno dos 900 metros. A porção oposta da Bacia, norte e oeste, possui uma rede de drenagem bem menor, com cursos d'água curtos e de perfil longitudinal pouco expressivo, onde o desnível topográfico é, em média, de 50 metros $(\mathrm{m})$ da nascente à foz. 
Seu perímetro é igual a $90 \mathrm{~km}$ com estimativa de 1,2 bilhões de metros cúbicos de água. Possui $127 \mathrm{~km}^{2}$ de superfície e vazão média estimada em $18 \mathrm{~m}^{3} / \mathrm{s}$, sendo que seu nível d'água é bastante variável devido ao bombeamento das águas dos rios Tietê e Pinheiros. O nível de água máximo normal é na cota de 747,65 m; o desaguamento é em Cubatão na Baixada Santista, sendo $74 \%$ de sua área localizada no município de São Bernardo do Campo. Seus principais rios e córregos formadores são: (1) rio Grande ou Jurubatuba, (2) ribeirão Pires, (3) rio Pequeno, (4) rio Pedra Branca, (5) rio Taquacetuba, (6) ribeirão Bororé, (7) ribeirão Cocaia, (8) ribeirão Guacuri, (9) ribeirão colônia, (10) córrego Grota Funda e (11) córrego Alvarenga (ZAGATTO \& BERTOLETTI, 2006). Alguns rios, córregos e ribeirões estão representados na FIG. 2.2 abaixo. 


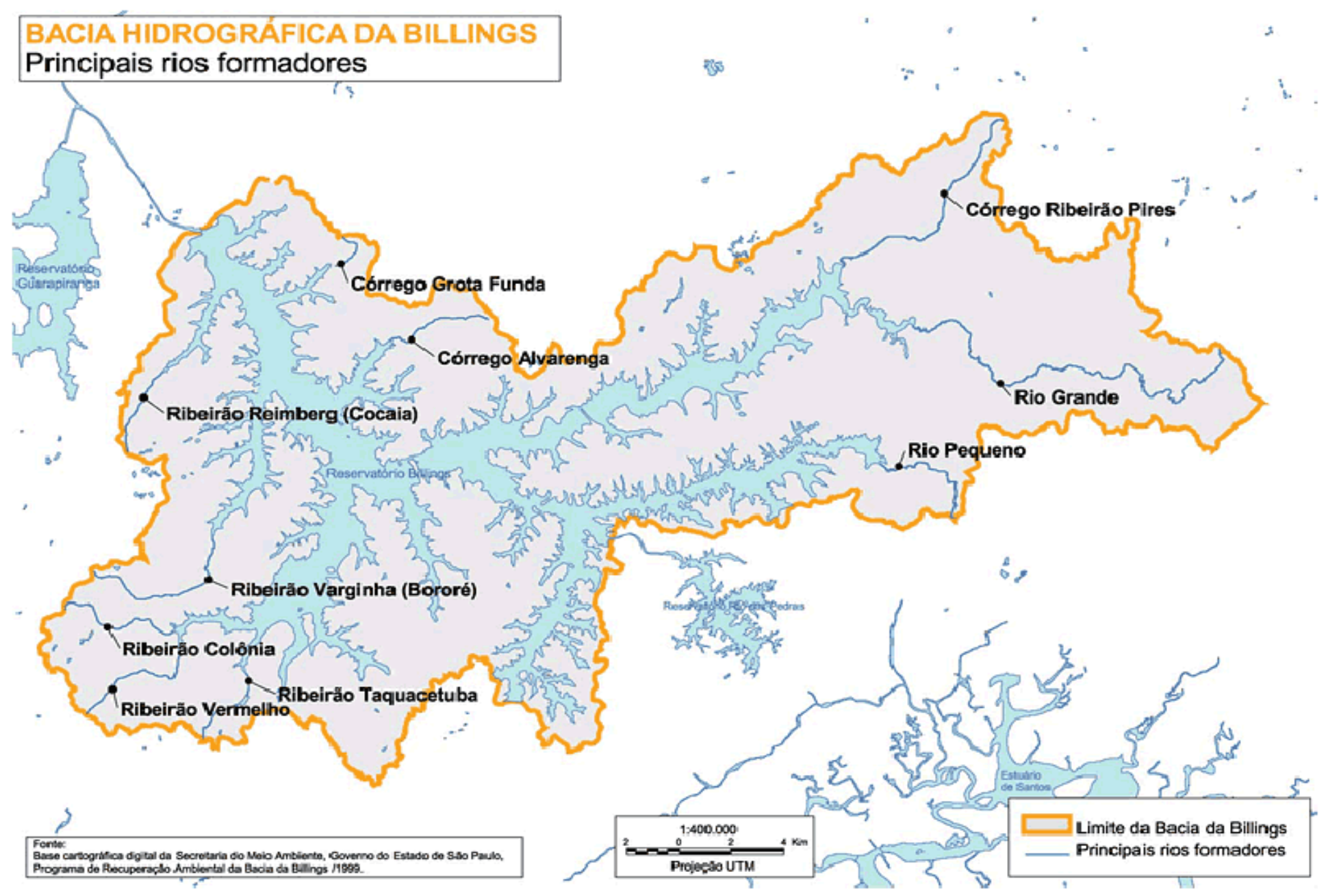

FIGURA 2.2 Principais rios formadores da bacia hidrográfica da Billings (adaptado de SVMA, 1999). 


\subsection{A urbanização no entorno da represa}

A industrialização e a urbanização foram rápidas e desordenadas às margens da represa Billings, o que contribuiu para a contaminação do manancial levando risco à saúde das pessoas, com elevados níveis de metais tóxicos que podem ser encontrados no meio ambiente.

A população que mora ao entorno da represa Billings caracteriza-se por pertencer a diversas classes sociais, culturais e religiosas. A região foi colonizada principalmente por alemães, japoneses e migrantes nordestinos que fizeram parte também da colonização da capital paulista. Na região encontram-se comunidades ribeirinhas e/ou pescadores, favelados, agricultores, fazendeiros, além disso, a região contempla um vasto patrimônio físico, como igrejas, templos, moradias, cemitérios e centros culturais (REITER et al., 2012).

De acordo com a FUNAI, além da população urbana e rural, há tribos indígenas instaladas ao redor das margens da represa. São duas aldeias pertencentes às tribos Krukutu e Tononde Porã, localizadas no extremo sul, em Parelheiros. Suas casas são bem simples e nem todas são de pau-a-pique, como nas tribos originais. Há muitos barracos e cômodos de alvenaria. A população da aldeia Krukutu soma 198 pessoas, sendo ao todo 36 famílias. Já a tribo Tenonde Porã é formada por 780 índios (120 famílias). A aldeia Krukutu possui 25 hectares, um a menos que a vizinha Tenonde Porã. A chegada das tribos data a década de 50, vindos da aldeia Rio Branco, em Itanháem, instalando-se primeiramente nas proximidades da ponte de Socorro e depois foram incentivados por famílias de japoneses que moravam na região, a se mudarem para Parelheiros às margens da represa Billings (CEDEFES, 2005). Problemas como a desnutrição, a falta de espaço à plantação, falta de matéria-prima para o artesanato e a diminuição da caça a cada ano vem dificultando a sobrevivência das tribos.

As áreas rurais encontradas na região do manancial Billings estão sendo substituídas por áreas urbanas. Segundo dados do IBGE, a população no entorno da Billings, de 1996 a 2000, aumentou de 170 mil habitantes para 863 mil. Em 2009, esse índice de crescimento se manteve numa média de $7 \%$, um pouco acima dos índices dos outros municípios, com exceção de Diadema, que cresce $10 \%$ ao ano (PROAM, 2009).

Comparando-se os índices de adensamento populacional máximo nos mananciais (áreas protegidas por lei), na cidade de Nova York nos EUA - a terceira cidade mais populosa da América, atrás da Cidade do México - esse índice foi determinado em 19 $\mathrm{hab} / \mathrm{km}^{2}$ - a agência de proteção ambiental do país assinou com vários estados um acordo 
para apoiar e proteger as bacias hidrográficas que abastecem com água potável a população (USEPA, 2004); no caso da cidade de São Paulo, a primeira cidade mais populosa da América, esse índice foi estimado em $3.500 \mathrm{hab} / \mathrm{km}^{2}$.

Muitas associações e organizações não-governamentais (ONG) foram criadas para fazer frente à degradação do reservatório e dos mananciais da cidade de São Paulo. De acordo com o instituto PROAM, diversas instituições, entre elas 120 ONG's, a Ordem dos Advogados do Brasil (OAB), Sociedade Brasileira para o Progresso da Ciência (SBPC) e Associação Brasileira de Imprensa (ABI) estão em defesa do maior manancial da cidade de São Paulo. Em 1994, a PROAM produziu o Dossiê Billings que foi apresentado em Washington - EUA e anualmente, elabora e divulga, desde o Relatório de Impactos Ambiental da represa Billings, com base no Dossiê Billings, pela Campanha "Billings, Eu te quero Viva!”. Esses relatórios apontam informações que precisam ser disseminadas sobre a questão da degradação ambiental para evitar os impactos causados ao meio ambiente.

Em um dos relatórios da PROAM é reportado que em curto prazo não haverá mais condições do reservatório abastecer o ABC paulista com a vazão de $5 \mathrm{~m}^{3} / \mathrm{s}$ e manter a transposição de suas águas ao sistema Guarapiranga, segundo maior reservatório da cidade com vazão de $4 \mathrm{~m}^{3} / \mathrm{s}$ e distribuir suas águas à grande parte da zona sul de São Paulo cuja população aproximava em quase 5 milhões de pessoas (PROAM, 2009; IBGE, 2013).

\subsection{Os problemas de poluição da represa Billings}

Os reservatórios são empreendimentos construídos pelo homem, com a finalidade de armazenar água para abastecimento ou para geração de energia elétrica. Estas obras modificam profundamente não somente os ambientes aquáticos, mas todo o ecossistema nele inserido. Através da construção de uma represa, há a inundação da área e aumento do tempo de residência da água. Essa ação ocasiona profundas mudanças na estrutura e funcionamento do ecossistema. Onde atuavam processos de transporte passam a atuar processos de deposição. O principal efeito desses empreendimentos é a inundação de áreas de várzea à montante e de menor disponibilidade de água à jusante. Como resultado, o novo ambiente pode ser considerado intermediário entre um rio e um lago (WALTER, 2000; SILVIA, 2002).

Brancatelli e Fortes (2011) relataram que o rio Tietê, em 1970, teve seu nível de oxigênio igual a zero, caracterizando um rio sem vida. Em 2011 o rio apresentou baixíssimos valores de oxigênio dissolvido no trecho por onde passa na cidade de 
Guarulhos (0,01 a 0,3 mg/l), ainda níveis baixos na capital ( 0 a 3,5 mg/l) e na sua trajetória não consegue chegar ao nível considerado saudável que é de $8,0 \mathrm{mg} / \mathrm{l}$, pois continua recebendo toneladas de dejetos, principalmente esgoto doméstico e lixo.

Os primeiros problemas de poluição da represa começaram repercutir ainda na década de 70 quando a CETESB foi obrigada a iniciar as operações de remoção da mancha anaeróbica presente na represa causada pelo bombeamento das águas do Tietê para a Billings, que combinados com o crescimento da cidade de São Paulo e a falta de coleta e tratamento de esgotos, trouxeram graves conseqüências ambientais, dentre elas a intensificação da poluição do rio Tietê e seus afluentes que por sua vez passaram a comprometer a qualidade da água da Billings (ISA, 2009).

Anos depois, devido aos sérios problemas de contaminação por algas cianofíceas (algumas espécies potencialmente tóxicas), surgiu a necessidade de interceptação total do Braço do Rio Grande, através da construção da Barragem Anchieta em 1982, garantindo a continuidade do abastecimento de água tratada (CETESB, 1993). Em 1989, a represa Billings chegou a um estado de tal calamidade ambiental que foi decretado o fim do abastecimento da represa pelos rios Tietê e Pinheiros (VICTORINO, 2002). Contudo, em 1992, criou-se uma Resolução Conjunta pela Secretaria do Meio Ambiente a SMA/SES 03/92, atualizada pela Resolução SEE-SMA-SRHSO-I, de 13/03/96, em relação ao problema do bombeamento dessas águas poluídas, permitindo o lançamento somente nos casos em que a previsão de vazão no rio Tietê, na confluência com o Canal Pinheiros, for superior a $160 \mathrm{~m}^{3} / \mathrm{s}$ ou ocorrer nesse local uma sobrelevação de $30 \mathrm{~cm}$ em relação ao nível verificado antes da ocorrência das chuvas (SILVA, et al., 2001; ONS, 2007; EMAE, 2008). Desde 1992 a concessionária EMAE vem atendendo às condições desta resolução e realizando o monitorando das águas do sistema TietêPinheiros-Billings.

Entre os anos de 1989 a 1999, outros impactos ambientais ocorreram, como a substituição da cobertura florestal nativa (Mata Atlântica), fundamental para a produção de água em quantidade e qualidade adequadas ao abastecimento público, por áreas ocupadas por atividades humanas, principalmente aquelas ligadas a usos urbanos. Este processo tem ocorrido através do surgimento de novas ocupações, consolidação da ocupação existente e transformação de áreas rurais em áreas urbanas. No período analisado, o manancial perdeu $6,6 \%$ de sua cobertura vegetal (ISA, 2009).

Grande parte da fauna não é mais presenciada. Através de relatos de moradores evidenciaram ter visto no local lontras, ariranhas, onças, antas, veados, castores, pacas e 
cotias. Martins (2007) descreve que esquilos, tatus, lagartos, bugios, capivaras, veados e gato-do-mato ainda são possíveis de serem avistados em locais como Barragem e Ilha do Bororé, este último local, ainda há um ninhario para diversas aves migratórias e regionais (PROAM, 2009). Muitos destes animais ainda são vistos em virtude desses lugares serem de soltura de animais pela Secretaria do Verde e do Meio Ambiente e por ONGs que ajudam a preservar a região.

Recentemente, o pouco que restou da mata atlântica foi retirado para a construção de um anel viário - o Rodoanel Mario Covas, um empreendimento rodoviário com objetivos múltiplos, o qual tem como função principal desviar do perímetro urbano da Região Metropolitana de São Paulo os veículos de passageiros e de cargas, diminuindo o fluxo de caminhões que circulam pela capital, ajudando aliviar o intenso tráfego nas duas vias marginais da cidade (Pinheiros e Tietê), cujo reflexo no tráfego urbano vem provocando grave situação de congestionamentos (MOREIRA, 2008).

De acordo com CAPOBIANCO (2002) a construção do anel viário pode provocar ainda mais a aceleração da urbanização da bacia, com o conseqüente risco de comprometimento em definitivo deste manancial estratégico para a Região Metropolitana de São Paulo. REINA (2007) relata que as obras do Trecho Sul do Rodoanel está aterrando uma parte da Represa Billings, em São Bernardo do Campo, região do ABC. Diversos ambientalistas temem pelo impacto à dinâmica da represa com possível aumento do assoreamento, da formação de cianofíceas, da concentração de nutrientes e poluentes orgânicos, comuns nesse trecho da Billings.

Há aqueles que caracterizam o empreendimento como sendo de grande potencial como elemento estruturador do uso e ocupação do solo e do processo de expansão urbana (LABHAB, 2005). De acordo com CEDEFES a maior preocupação dos índios agora é a construção do Rodoanel, pois as estradas ficarão a $3 \mathrm{~km}$ de suas terras. Atualmente sua implantação ainda não foi totalmente concluída nos 4 trechos (norte, sul, leste e oeste) da cidade, entretanto, o trecho sul é preocupante por tratar-se de área de proteção aos mananciais, com mínima capacidade de suporte à expansão urbana.

Outros locais impactados são os campos naturais do alto da Serra do Mar que continuam sendo degradados devido à retirada de húmus do local para comercialização, não importando ser um ecossistema de produção de água e fragilizando-o constantemente. Esses campos naturais ajudam a reter a água das chuvas provenientes da evaporação do Oceano Atlântico e das represas, cuja condensação ocorre na passagem pela Serra do Mar, 
impulsionada pelo vento sudoeste (PROAM, 2009). Muitos outros fatores precisam ser destacados, tais como: aterramento de nascentes, especulação imobiliária, impermeabilização do solo por loteamentos e construções irregulares, invasões clandestinas, degradação de encostas, assoreamento, adensamento populacional, caça ilegal e pesca em excesso, lixos doméstico, químico e industrial, chorume de aterros sanitários, cemitérios clandestinos, rituais religiosos que provocam incêndios na mata e o bombeamento das águas poluídas dos rios Tietê e Pinheiros.

Quando a contaminação gera impacto ambiental afetando todo o ecossistema e consequentemente suas comunidades, isso significa que a contaminação pode colocá-las sob riscos potenciais pelos aportes de poluição; quando não há o manejo adequado, assim como o tratamento ou a prevenção da contaminação, muitas doenças patogênicas se propagam; substâncias químicas e suas misturas tendem a aumentar no meio ambiente (BAZANTE-YAMAGUISHI, 2007).

Casos graves de doenças e óbitos em população indígena é um retrato em regiões onde o saneamento básico é precário (INESC, 2004; TEIXEIRA, 2008; CHAMY, 2004). Atualmente, com a compensação ambiental efetuada pela empresa Furnas ${ }^{2}$, que passou uma linha de transmissão na região entre duas aldeias de Parelheiros (região sul), a população indígena está sendo atendida em um posto de saúde em sua sede. Também foram contemplados com um açude, onde cultivam seus peixes e um campo de futebol (CEDEFES, 2005). A FUNASA - é responsável pelo Subsistema de Saúde Indígena que realiza o atendimento básico às populações indígenas nos Distritos Sanitários Especiais Indígenas e encaminha e acompanha os casos de maior complexidade para o SUS (TEIXEIRA, 2008), em 2001, construiu também um poço artesiano, sendo por direito consuetudinário, o que melhorou o problema da água em época de estiagem, entretanto, os dados de sua potabilidade não estão publicados.

Diante de tantos estudos sobre a represa Billings, destaca-se o impacto ambiental causado por metais tóxicos, decorrente do processo continuo do crescimento populacional, das atividades industriais e da falta de gerenciamento dos órgãos competentes no controle da qualidade das águas que são utilizadas para o abastecimento público na região. De acordo com SOLIA et al. (2007), dos onze rios e córregos formadores do complexo Billings, apenas dois não estão acima do VMP e são utilizados para o abastecimento de água potável cujo tratamento é realizado pela Companhia de

${ }^{2}$ Furnas: empresa de geração e transmissão de energia, de economia mista, subsidiária da Centrais Elétricas Brasileiras S.A. - Eletrobras, vinculada ao Ministério de Minas e Energia. Link: http://www.furnas.com.br/ 
Saneamento Básico do Estado de São Paulo - SABESP: o braço Taquacetuba e o rio Grande. Atualmente, esses dois importantes mananciais abastecem a Região Metropolitana de São Paulo e também o trecho Taquacetuba reverte água para a represa Guarapiranga.

Em 2006, no ponto de captação da SABESP no braço Taquacetuba, a quantidade de células de cianofíceas encontrada ultrapassou o valor máximo estabelecido pelo padrão de potabilidade vigente (20.000 células $/ \mathrm{ml})$, indicando a necessidade de intensificação do monitoramento (CETESB, 2007). Observando dados do diagnóstico da comunidade bentônica da represa Billings, em 2004 e 2005, no ponto BILL 02100, houve o desaparecimento da população sensível - efemeróptero Polymitarcyidae - que é um macroinvertebrado bentônico e bioindicador da qualidade da água natural (CETESB, 2007). De acordo com o relatório da CETESB (2007), esses organismos bentônicos foram encontrados pela primeira vez, em mais de 10 anos de estudos, no bentos sublitoral de 2006, o que refletiu em baixa concentração de oxigênio e condição supereutrófica na represa Billings. CUMMINS et al. (2005) descreveram que são organismos anfibióticos, sensivel a baixas concentrações de oxigênio na água. Os adultos têm hábito terrestre e os imaturos aquáticos que ocorrem praticamente em todos os tipos de corpos d'água.

Não há dúvidas de que o principal aporte do material fino que compõe os sedimentos do reservatório, assim como de seus contaminantes, provém das águas poluídas da bacia dos rios Tietê e Pinheiros, que adentram pela Usina Elevatória de Pedreira, quando as águas são bombeadas para dentro do reservatório em duas situações emergenciais: (1) quando a vazão destes rios está acima de $160 \mathrm{~m}^{3} / \mathrm{s}$, devido a precipitações ou (2) para elevar o nível do reservatório (CETESB, 1993). Rocha (1985) encontrou metais em amostras de peixes coletados na represa Billings, tais como chumbo, mercúrio e cádmio, distribuídos nas partes da musculatura e víscera de determinadas espécies. Sabe-se que alguns metais tem efeito crônico na saúde dos organismos e são bioacumulativos.

Na capital de São Paulo, com a finalidade de promover melhoria das condições ambientais das águas afluentes ao canal do rio Pinheiros para que pudessem ser revertidas ao reservatório Billings e o aumento da capacidade de geração da Usina Henry Borden foi dado início ao projeto de despoluição do rio Pinheiros por meio da flotação em 2001 (EMAE, 2008). De acordo com a EMAE (2008), a meta foi garantir que as águas do rio Pinheiros atinjam o reservatório Billings com padrões de qualidade compatíveis a Classe 2, (CONAMA, 2005). No entanto, esse projeto foi finalizado em 2009. 
A situação se torna ainda mais crítica quando se avalia os diversos metais que são incorporados aos sistemas (rio e reservatório) advindos dos efluentes industriais e domésticos. Estudos desenvolvidos pela CETESB (2001) nos programas de monitoramento têm demonstrado que as concentrações de chumbo e manganês estão acima dos padrões exigidos pelo CONAMA para águas de classe 2 (EMAE, 2008).

Em relação aos sedimentos, determinados pontos do reservatório apresentaram metais tóxicos. Esses estão biodisponíveis aos organismos aquáticos e aos demais na cadeia alimentar, incluindo o homem (SILVIA et al., 2002; MARIANI, 2006; ARAUJO et al. 2006; HORTELLANI et al., 2013). Outros estudos sobre abordagens concernentes à represa Billings encontram-se contemplados em diversas produções bibliográficas, dentre as quais se destacam: COSTA et al., (1998); MUNIZ (2004); SILVIA et al., (2002); CAPOBIANCO (2002); SILVÉRIO (2003); CASTRO et al. (2004); SAMPAIO (2007); ALVES DA SILVA (2008); OLIVEIRA et al., (2012); HORTELLANI et al., (2013), FURLAN et al., (2013) cujas tendências passaram a incluir parâmetros de qualidade, avaliações temporais, ações antropogênicas, comunidades residentes, ativos potenciais de riscos a saúde da vida aquática e humana.

\subsection{Sobre o monitoramento da qualidade da água}

Para Uil et al. (1999), o monitoramento é uma ferramenta de gerenciamento e para Dias (2005) é a coleta de dados com o propósito de obter informações sobre uma característica e/ou comportamento de uma variável ambiental.

A CETESB vem realizando o monitoramento das águas da Billings, desde a década de 70, entretanto, somente começou um monitoramento integrado das águas em 1991 (CETESB, 2001). Dentre os metais analisados pela CETESB, destacam-se 11: o alumínio $(\mathrm{Al})$, bário $(\mathrm{Ba})$, cádmio $(\mathrm{Cd})$, chumbo $(\mathrm{Pb})$, cobre $(\mathrm{Cu})$, cromo total $(\mathrm{Cr})$, ferro $(\mathrm{Fe})$, manganês $(\mathrm{Mn})$, mercúrio $(\mathrm{Hg})$, níquel $(\mathrm{Ni})$ e zinco $(\mathrm{Zn})$. No capítulo 3, exploram-se num estudo mais detalhado os resultados em domínio público desses metais na água.

O monitoramento da qualidade das águas subterrâneas no estado de São Paulo completou em 2012, um pouco mais de duas décadas de existência. Segundo relatórios publicados pela CETESB, apenas quatro foram publicados até o momento (trianual) e incluiem dados de 175 locais onde há ocorrência de águas subterrâneas tanto nos municípios quanto na RMSP.

As águas subterrâneas têm importante papel no abastecimento público e privado no Estado de São Paulo, onde $72 \%$ dos municípios são total ou parcialmente 
abastecidos por esse recurso hídrico (CETESB, 2001, 2004). Entretanto, a distribuição é desordenada e a falta de saneamento básico atinge grande parte da população.

Barbosa (2005) observou que em regiões onde não há coleta de esgoto, o material orgânico depositado em fossas e sumidouros são biotransformados e lixiviados no meio ambiente, causando contaminação aos mananciais superficiais e subterrâneos.

É importante realizar a investigação detalhada da qualidade da água subterrânea, iniciando por: estabelecer a finalidade do uso; identificar o potencial problema como corrosão ou incrustação, limpeza de tubulações ou locais de armazenamento da água (caixa d'água) e realizar um estudo do sistema de fluxo da água subterrânea, de forma que a investigação tome por base, dados da profundidade do poço, tendências sazonais a longo prazo e tendências naturais do próprio solo ou ainda induzidos por bombas hidráulicas.

\section{6. Água subterrânea}

Águas subterrâneas são águas que ocorrem natural ou artificialmente no subsolo, e são suscetíveis de extração e utilização pelo homem. Seu gerenciamento sustentável inclui a utilização equilibrada, tanto em qualidade como em quantidade, com base no conhecimento sobre os impactos potenciais de contaminantes antrópicos ou naturais e as taxas de recarga e de exploração, além das considerações sobre as propriedades do uso da água (IRITANI \& EZAKI, 2008).

Extrair água subterrânea para o consumo é uma arte milenar. Acredita-se que as águas subterrâneas são usadas há mais de cinco mil anos A.C. pela população chinesa, através da construção de poços rasos escavados. Civilizações antigas, entre elas os egípcios, árabes, assírios, babilônios, chineses e hindus, já usavam sistemas de irrigação com grande êxito, inclusive envolvendo as águas subterrâneas. Há 2.500 anos, os egípcios tinham 400.000 hectares irrigados com águas vindas de aquíferos ${ }^{3}$, por gravidade, através de túneis sub-horizontais (qanats) (HIRATA \& VANIER, 1998). Segundo Chilton (1995), na região oeste dos desertos do Saara, ruínas históricas mostram áreas irrigadas com águas obtidas através de poços com mais de 200 metros de profundidade. Estas técnicas foram disseminadas em toda a região do Médio Oriente, chegando à Asia e á Europa.

Existem quatro tipos de formações aquíferas na obtenção de água subterrânea: (A) aquífero fissural e (B) cárstico-fissural (em rocha consolidada) e (C) aquífero intersticial e (D) aluvial (em rochas sedimentar não consolidada). A diferença está na

3 Aquífero (resolução 396/08 do CONAMA) é o corpo hidrogeológico com capacidade de acumular e transmitir água através dos seus poros, fissuras ou espaços resultantes da dissolução e carreamento de materiais rochosos 
natureza desses dois tipos gerais de formação aquíferas o que influenciará no projeto de construção do poço (FIG.2.3.).
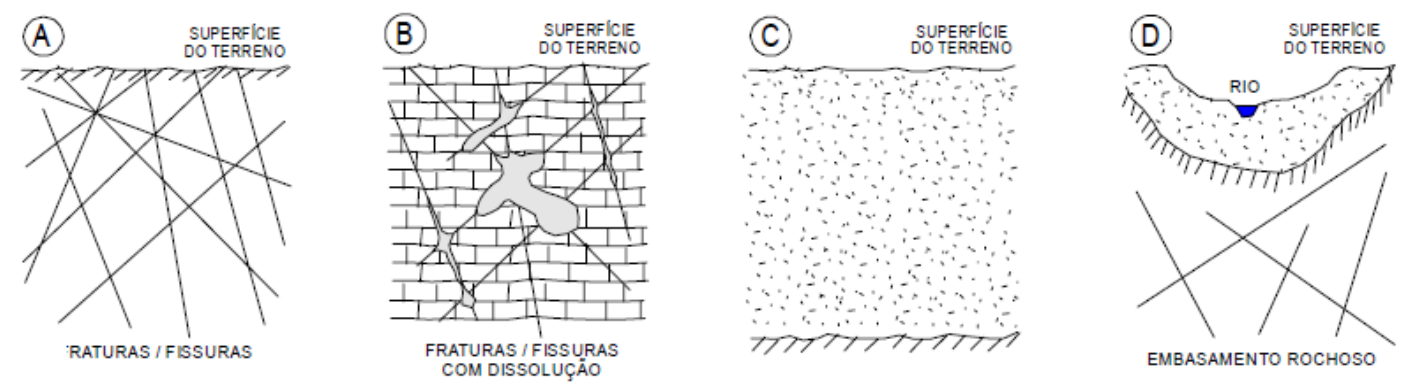

FIGURA 2.3 - Tipos de formações aquíferas (CPRM, 1998).

Os poços podem ser caracterizados rasos (até $20 \mathrm{~m}$ de profundidade) ou profundos (acima de $20 \mathrm{~m}$ de profundidade). O poço tubular ou poço profundo precisa de equipamentos para contenção de sua água, já que a mesma jorra do aquífero confinado. $\mathrm{O}$ aquífero confinado é aquele situado entre duas camadas confinantes, contendo água com pressão suficiente para elevá-la acima do seu topo ou da superfície do solo (FIG. 2.4).

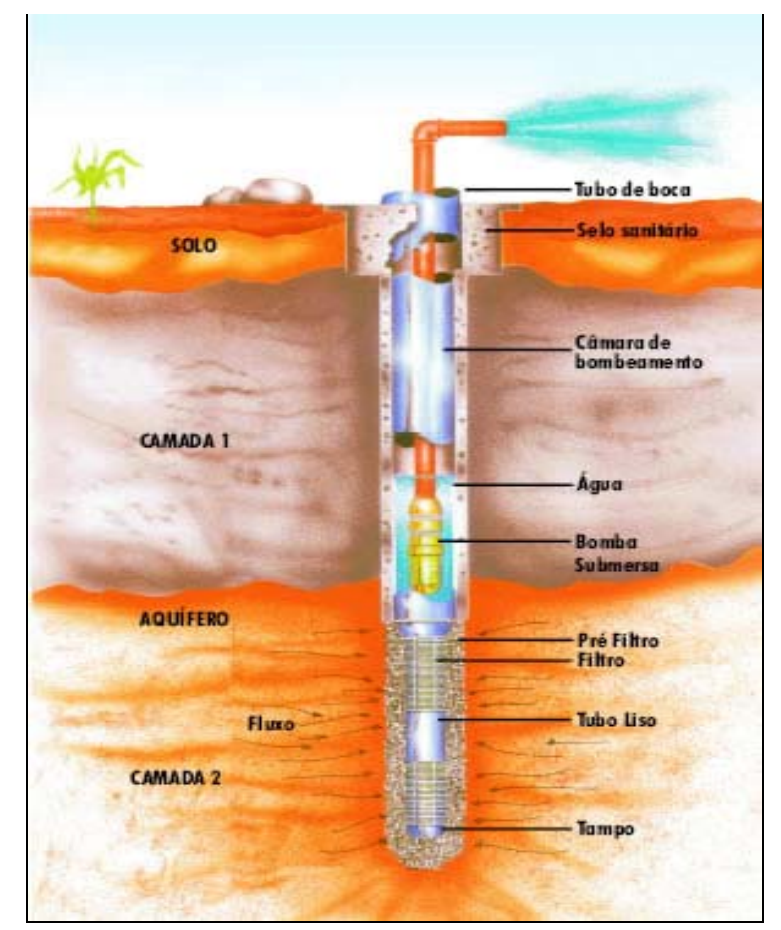

FIGURA 2.4 - Poço tubular. 
Quando um poço é perfurado numa formação de rocha consolidada, o orifício geralmente é mantido em equilíbrio, sem necessidade de revestimento, enquanto que, numa formação de areia, argilas expansivas, pedregulho e outras formações não consolidadas, deverá ser sustentado por um revestimento, filtro para poço, a fim de evitar seu desmoronamento ou fechamento do poço (CPRM, 1998). A água nas formações consolidadas ocorre nas fraturas, fendas ou cavernas existentes nas rochas ou nos poros do arenito, enquanto que nas areias e pedregulhos, está presente nos vazios formados entre partículas adjacentes.

O poço semi-artesiano é o nome popular dado ao poço cuja obtenção de água necessita de equipamentos, pois suas águas não jorram até a superfície do solo. Utiliza-se bombas submersíveis, bombas de recalque, bombas manuais, bombas de eixo prolongado entre outros tipos.

As nomenclaturas poço raso, cisterna, cacimba ou caipira são todos que caracterizam poços cuja captação de água é feita do aqüífero não confinado, ou seja, são depósitos de águas subterrâneas em pequena profundidade. A água obtida nesse tipo de captação está sujeita a contaminações difusas ou pontuais, como a água da chuva ou efluentes industriais e domésticos que podem levar substâncias químicas tóxicas ou doenças patógenas ao homem e seu volume pode ser prejudicado em épocas de longa estiagem. A qualidade da água subterrânea dependerá das características de seu ciclo natural da água em conjunto com qualquer mudança que ocorra, como um resultado da atividade humana ou animal. Além disso, as análises química, física, biológica e os dados geomorfológicos são responsáveis por delinear quantitativa e qualitativamente sua finalidade de uso.

O ciclo da água subterrânea pode ser dividido em três etapas: (i) recarga, (ii) circulação de água no subsolo e (iii) descarga (SAMPAIO, 2012).

A recarga (entrada de água no sistema hidrogeológico) dá-se principalmente a partir do excedente da precipitação, ou seja, a alimentação é feita pela água que não é evaporada, evapotranspirada ou sujeita a escorrência superficial. Por outro lado, a entrada de água também pode ser proveniente de rios ou de lagos que alimentam o aquífero ou da injeção direta em furos (recarga artificial). A maior parte das águas subterrâneas origina-se de água da chuva, a qual se infiltra através da zona insaturada. Durante este processo, a composição da água é constantemente modificada pelas interações com os constituintes minerais do solo e das rochas (FIG. 2.5.a,b). 
a)

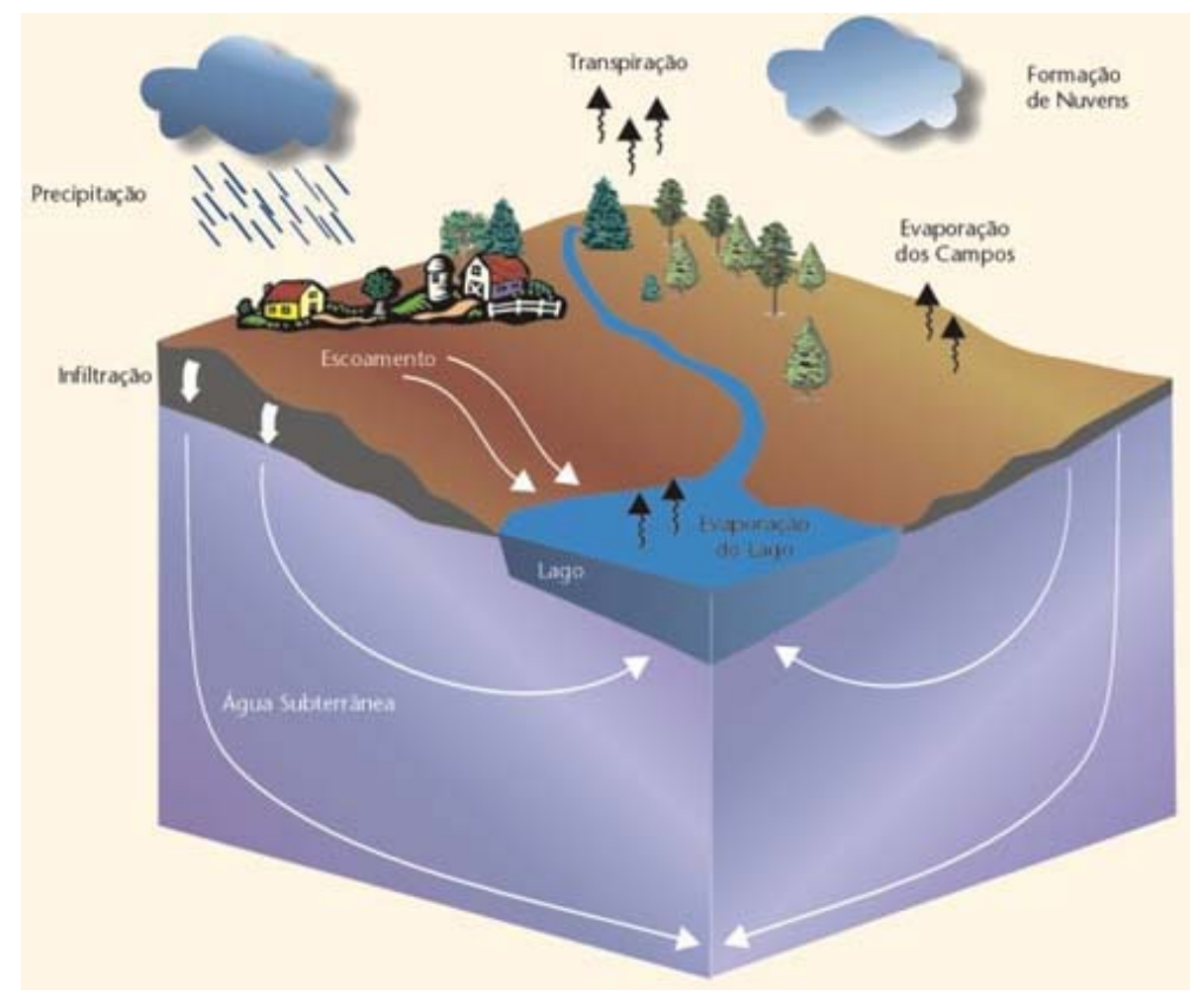

b)

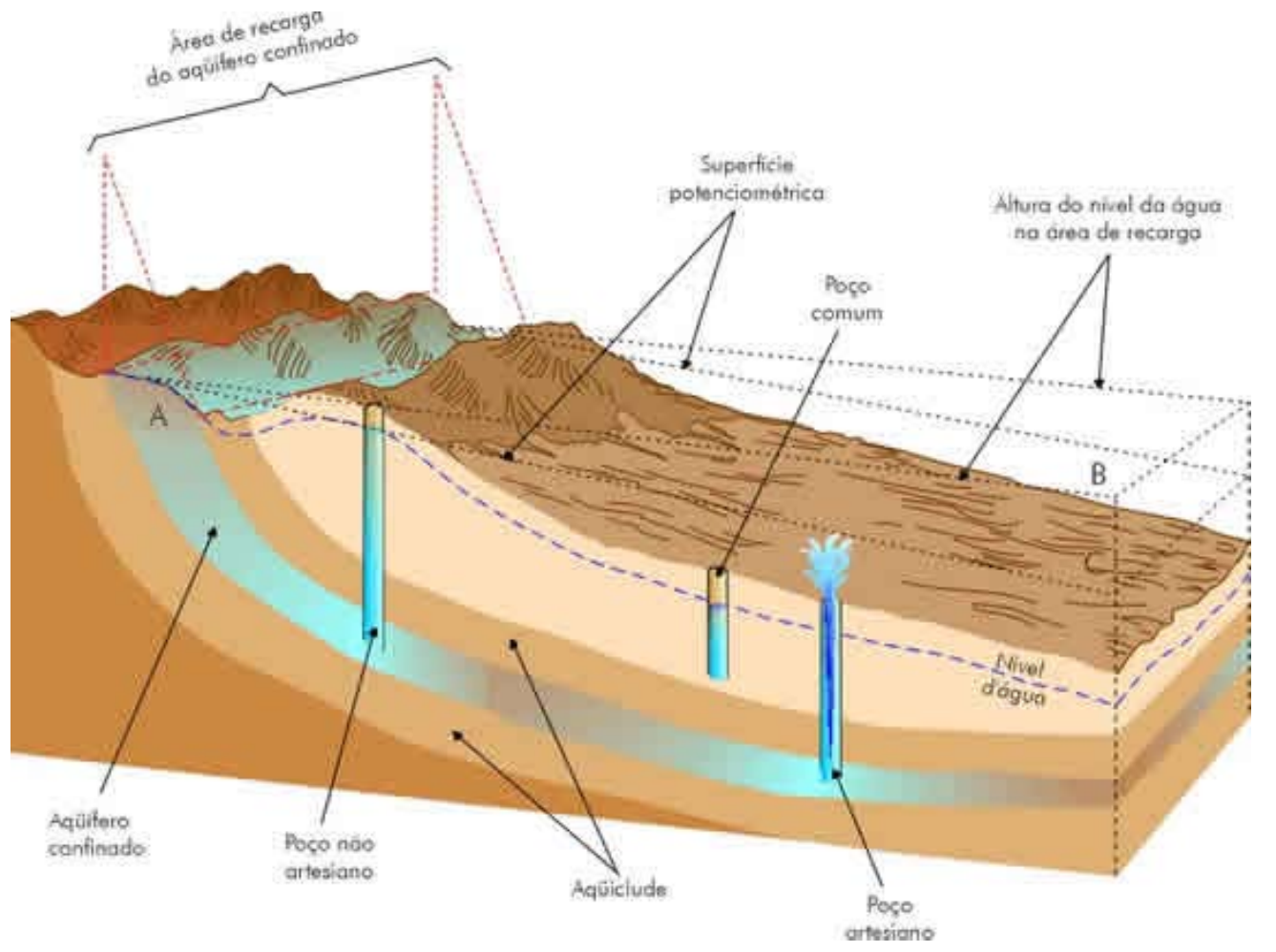

FIGURA 2.5. a) Ciclo da água subterrânea e b) tipos de poços 
Os constituintes químicos das águas subterrâneas podem ser influenciados por quatro fatores: deposição atmosférica, processos químicos de dissolução e/ou hidrólise no aquífero, mistura com esgoto ou outras atividades humana e/ou animal e águas salinas por intrusão (TUNDISI, 2003).

Com o crescente aumento do custo para tratamento de águas superficiais, a água subterrânea vem se tornando a alternativa mais viável para o consumo humano, desde que ela não necessite de tratamento, pois também corre o risco de estar contaminada por diversas fontes (MISSTEAR et al., 2007).

No mundo inteiro, os aqüíferos estão sob perigo cada vez maior de contaminação em decorrência da urbanização, do desenvolvimento industrial, das atividades agrícolas e das empresas de mineração. É certo que os aquíferos, embora possuam grande capacidade de armazenamento de água, muitas vezes não respondem com elevadas vazões pontuais instantâneas, limitando a produção final de sistemas de extração para alguns usos de grande demanda (HIRATA \& VANIER, 1998).

O uso deste tipo de recurso hídrico está associado ao avanço tecnológico para sua exploração em grandes profundidades e em termos de qualidade, onde a intervenção humana não causou nenhum tipo de poluição e sua pureza em termos bacteriológicos é de 99,99 \%. Em algumas regiões no Brasil o número percentual do uso em geral da água subterrânea é muito superior ao número percentual das águas superficiais (FIG. 2.6). 


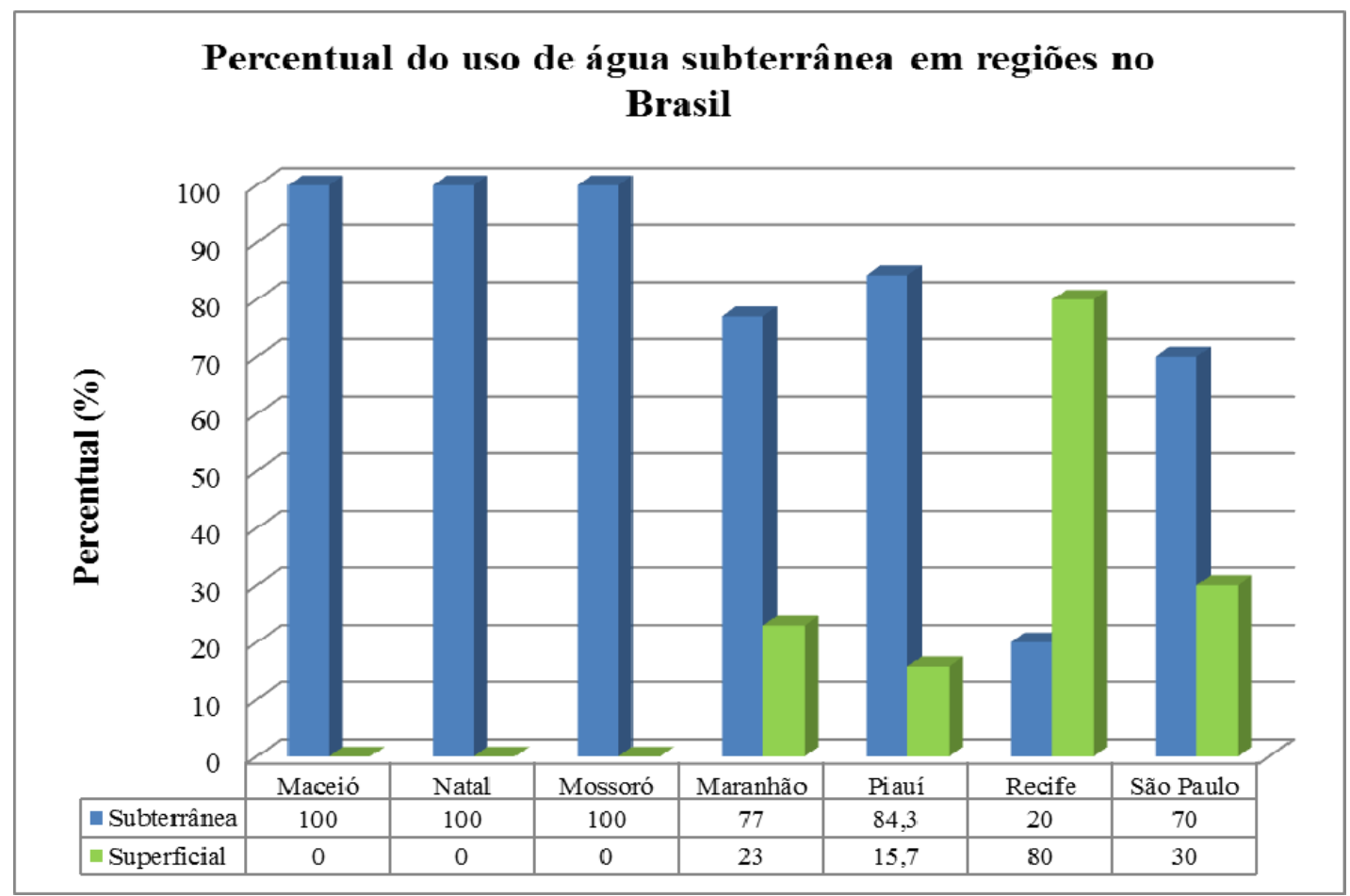

FIGURA 2.6 - Percentual do uso de água subterrânea em cidades no Brasil (SAMPAIO, 2012).

Como foi citado no item 2.1, a população da RMSP está em torno de 20,7 milhões e a demanda por água cresce em 2 milhões $\mathrm{m}^{3} / \mathrm{ano}$, de forma que o potencial hídrico da região não apresenta sustentabilidade para o abastecimento público. Dessa forma, a cidade de São Paulo acaba importando a água de outras regiões, como a Bacia do rio Piracicaba (34 m³ $/$ segundo - por meio do sistema Cantareira), que por sua vez apresenta grande crescimento e dificuldades para suprir sua demanda para abastecimento humano, industrial e agrícola. Como o potencial de captação encontra-se esgotado naquela região, desde 1994, vêm ocorrendo manifestações por parte de municipalidades locais prenunciando um confronto com a RMSP pelo uso de recursos hídricos (PROAM, 2005).

A solução para o abastecimento da população estaria na extração de águas subterrâneas, mas isso implicaria em elevados custos e riscos decorrentes do subsolo metropolitano, como a formação de silk-holes (formação de cavernas por extração de águafato já ocorrido em Cajamar-SP) o que poderia provocar acomodação de camadas devido à origem sedimentar do solo - e consequentes desabamentos. A extração de água do subsolo metropolitano está descartada, com pequeno potencial disponível, inferior a $3 \mathrm{~m}^{3} /$ segundo. A Cidade do México, única no mundo que supera São Paulo em precariedade de água, apresenta em sua periferia uma acomodação de camadas que tem provocado um 
rebaixamento do solo em até meio metro por ano, devido à extração excessiva de água subterrânea e até a injeção de esgotos no subsolo foi tentada para deter o rebaixamento (NÁJAR, 2009).

Atualmente em São Paulo, a licença para perfuração e utilização de um poço é concedida pelo Departamento de Águas e Energia Elétrica (DAEE), que estabelece as normas que regem o projeto de construção de poços tubulares profundos e controlam sua utilização, cabendo à SABESP a responsabilidade pelo tratamento da água, incluindo também a de poços, com exceção a poços particulares. No entanto, a SABESP alerta para os riscos à saúde de fontes alternativas, caso não haja tratamento e controle adequado, embora enfatize ao usuário que um litro de água de poços custa 15 vezes menos do que um litro de água de fontes superficiais.

Um estudo sobre a qualidade da água subterrânea (poços) consumida por famílias de pescadores da região da represa Billings foi realizado no ano de 2011. Neste estudo promovido pela organização não-governamental ATIBORÉ com apoio do FEMA da SVMA, foram analisados periodicamente os 11 metais citados no item 2.6, onde se constatou o metal alumínio causando a contaminação nessas águas.

\subsection{Características geológicas dos aquíferos em São Paulo}

Existem basicamente dois sistemas aqüíferos na RMSP, o cristalino e o sedimentar (bacia de São Paulo), de idade terciária (cenozóico). Mas há também as chamadas coberturas aluviais mais recentes (idade quaternária), que se desenvolveram ao longo dos principais rios da cidade (rios Tietê, Pinheiros e Tamanduateí). Todo o sistema aquífero da bacia de São Paulo, ocupado inteiramente pela metrópole, é composto por arenitos argilosos, argilas e lentes de areia (porosos), com espessura média de 100 metros, podendo alcançar 230 metros. Apesar de sua pequena área de mil quilômetros quadrados há a sua exploração por mais de 8 mil poços tubulares com produtividade média de $6 \mathrm{~m}^{3} / \mathrm{h}$, que abastecem indústrias, hospitais, escolas, residências e condomínios, de forma suplementar (DAEE, 2010; CBH-AT, 2010).

Segundo SILVA (2000) e HIRATA \& FERREIRA (2001), especificamente o sistema aqüífero cristalino ocorre nas rochas ou terrenos cristalinos e a profundidade de seus poços podem variar de 50 a 150 metros com vazões que atingem de 2 a $40 \mathrm{~m}^{3} / \mathrm{h}$ e uma média de $5 \mathrm{~m}^{3} / \mathrm{h}$.

Os pontos de amostragem de águas subterrâneas devem ser distribuídos de forma a abranger os diferentes aqüíferos porosos e fraturados no estado de São Paulo, em 
suas diversas áreas e formas de ocorrência. Em 2003, iniciou-se a amostragem de água em poços e nascentes na RMSP. Especificamente na zona sul, os números de poços cadastrados pelo DAEE e monitorados pela CETESB são ao todo seis; é também na zona sul que encontramos 725 casos confirmados de áreas contaminadas (DAEE, 2010), onde fica o maior manancial de abastecimento público - a represa Billings.

\subsection{Características climáticas}

Estações meteorológicas e hidrológicas mais estudadas na região da represa Billings estão destacadas na FIG.2.7. Para caracterizar um período de 20 anos, a PROAM, realizou um estudo e pesquisou um determinado ponto, o P-12-042, controlado pela EMAE que fica localizado na Barragem de Pedreira na represa Billings (posição georreferenciada: $\left.23^{\circ} 41^{\prime} 59^{\prime \prime} 46^{\circ} 40^{\prime} 11^{\prime \prime}\right)$. Nesse estudo observou-se que os meses de novembro a abril referem-se à estação de chuvas e de alta temperatura; os meses de junho a setembro referem-se à estação seca cujas temperaturas relativas são mais baixas. De acordo com PROAM, a temperatura média mensal de 20 anos (1985 a 2004) na Barragem de Pedreira foi de 16,6 a $23,4{ }^{\circ} \mathrm{C}$, sendo a mais baixa registrada no mês de julho e a mais alta no mês de fevereiro, com uma média anual de $20,1{ }^{\circ} \mathrm{C}$, mínima $0,0{ }^{\circ} \mathrm{C}$ e máxima $36,0{ }^{\circ} \mathrm{C}$.

$\mathrm{Na}$ estação chuvosa, massas de ar de temperatura elevada e alto grau de umidade, provenientes do Oceano Atlântico ao sul, chocam-se com a Serra do Mar e provocam grande quantidade de chuva e por isso a encosta sul da Serra do Mar e todo o lado sul da bacia, que se constitui na borda da região planáltica, torna-se uma área de muita chuva. A umidade relativa mensal nesse mesmo período foi de 77,8 a $81,0 \%$, sendo o índice mais baixo em agosto e o mais alto em fevereiro e a média anual foi de 79,1 a 83,1 \% (média de 80,6 \%) e não se verifica uma variação significativa (PROAM, 2009). 


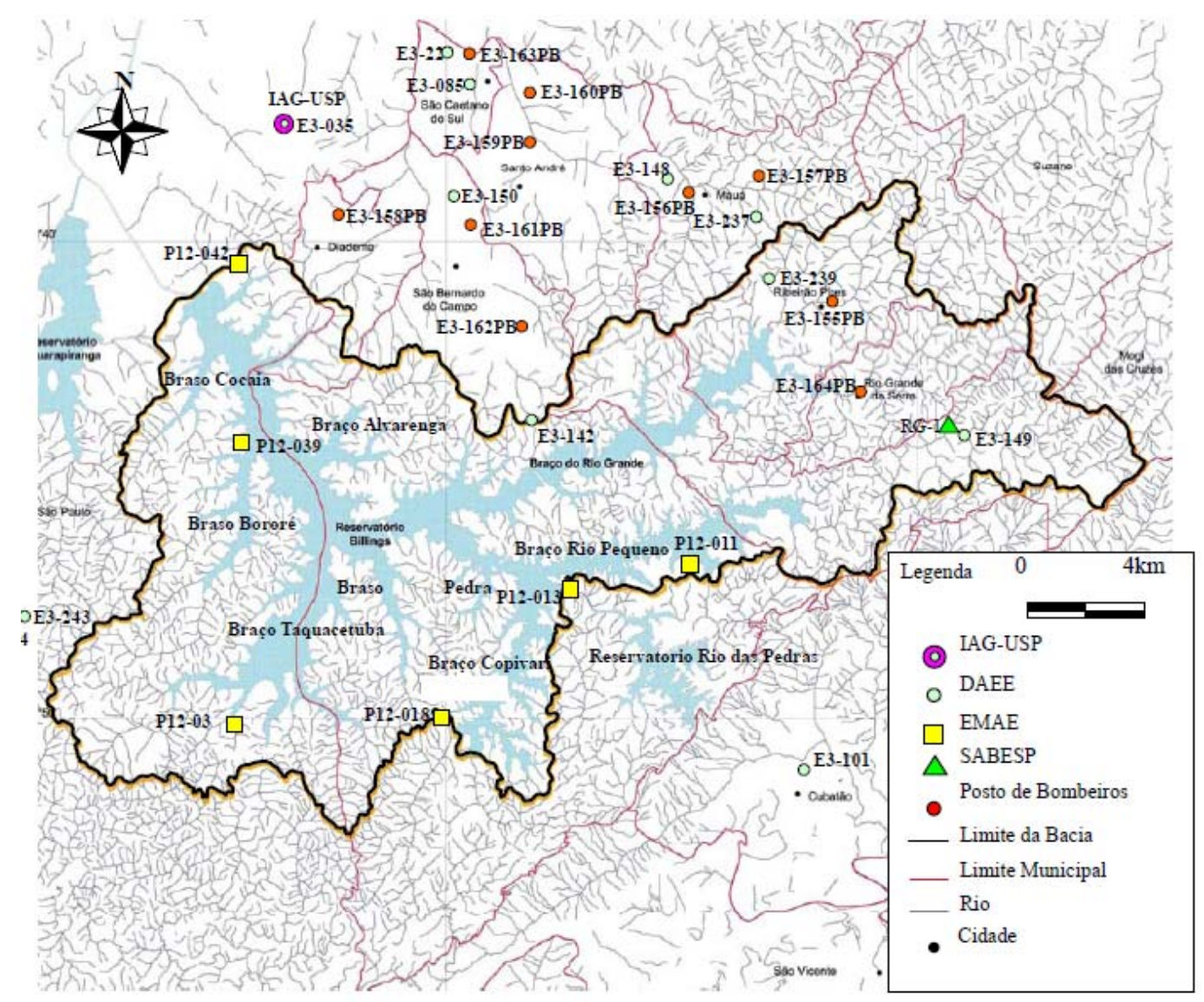

FIGURA 2.7 - Localização das estações meteorológicas e hidrológicas na região da represa Billings (PROAM, 2009)

\subsection{Legislações e Normatizações de Qualidade de Recursos Hídricos}

No Brasil, as legislações que estabelecem os limites aceitáveis para os metais em água, bem como a sua potabilidade estão definidos pela resolução CONAMA 357/05 e pela portaria 2914/11, antiga portaria 518/04 do Ministério da Saúde, respectivamente, esta última, estabelece os limites permitidos dos parâmetros de avaliação da potabilidade da água.

Além dessas em específico, foram utilizados normas e protocolos de agências ambientais estrangeiras como referências nos processos de amostragem e análise microbiológica, química e físico-química das águas de poços na região da represa Billings. Protocolos da American Public Health Association - APHA, United States Environmental Agency - USEPA e Companhia Ambiental do Estado de São Paulo - CETESB.

A resolução CONAMA 396 de 2008 dispõe sobre a classificação e diretrizes ambientais para o enquadramento das características de águas subterrâneas. Considerando que as águas subterrâneas possuem características físicas, químicas e biológicas 
intrínsecas, com variações hidrogeoquímicas, sendo necessário que as suas classes de qualidade sejam pautadas nessas especificidades. De acordo com esta resolução, uma vez poluídas ou contaminadas a remediação das águas subterrâneas é lenta e onerosa.

Em relação ao solo e águas subterrâneas não existia regulamentação desde 2001, até que foi estabelecido valores de intervenção para os diferentes contaminantes. Antes mesmo das leis de intervenção, a CETESB implantou valores orientadores baseados em modelos internacionais para investigar e gerar um banco de dados dos principais contaminantes químicos ambientais relacionados à saúde humana (CETESB, 2001), são eles: a) Valor de Referência de Qualidade (VRQ); b) Valor de Prevenção (VP) e c) Valor de Intervenção (VI). De acordo SAMPAIO (2007) uma área é classificada como contaminada, somente quando houver constatação da presença de contaminantes sob investigação do solo ou da água subterrânea, em concentrações acima dos VI, indicando a necessidade de ações para resguardar os receptores de risco.

Dessa forma, o monitoramento se faz obrigatório, efetuando um diagnóstico de qualidade desses meios (solo e água subterrânea), identificando e controlando as possíveis fontes de poluição (PEDROZO, 2004). Em 2005, por Decisão de Diretoria, no 195-2005-E, os valores sofreram alteração e foram novamente definidos (TAB 2.2).

A nova Lei de Proteção e Recuperação dos Mananciais (13.579/09) introduz critérios mais flexíveis que permitem a busca de soluções viáveis para os problemas presentes na área de mananciais. Esta lei estabelece a bacia hidrográfica como unidade de planejamento e gerenciamento e prevê o estabelecimento de uma Lei Específica - 3579 para cada Área de Proteção e Recuperação de Mananciais - APRM, permitindo assim, adequar a Lei com a realidade e as especificidades da região, bem como com a participação dos municípios e de representantes da sociedade organizada. Além disso, prevê a implantação de um Plano Emergencial para a resolução dos problemas mais críticos e abre a possibilidade de se efetuar o tratamento dos resíduos sólidos e dos efluentes sanitários dentro da própria bacia, o que pela legislação anterior não era possível. Esse projeto visa justamente a preparação do Plano Diretor para a Área de Proteção aos Mananciais do Município de São Bernardo do Campo, que deverá constituir as bases para o Plano de Desenvolvimento e Proteção Ambiental a ser levado para a discussão no Sub-comitê da Bacia Hidrográfica da Billings, juntamente com as propostas dos demais municípios. 
TABELA 2.2 - Valores orientadores para solo e água subterrânea no Estado de São Paulo (CETESB, 2005).

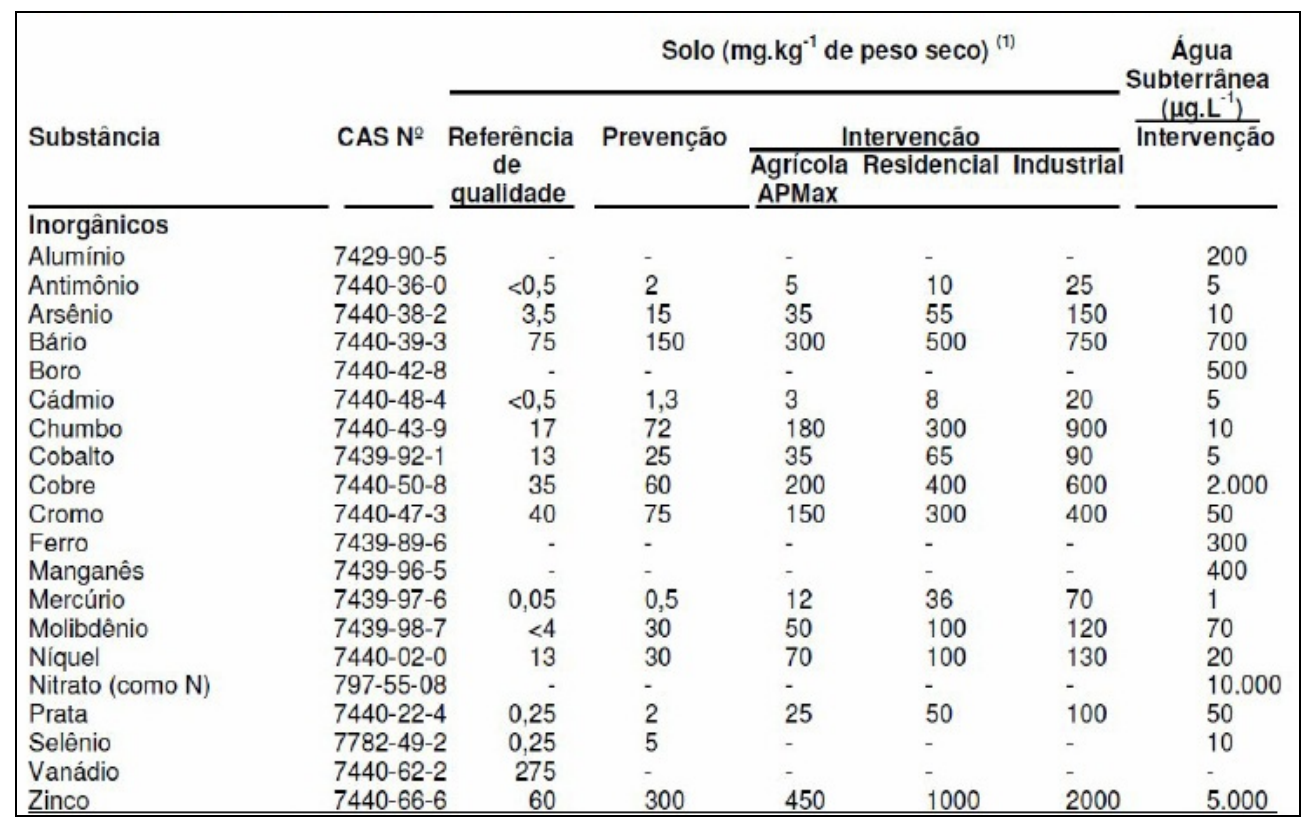

De acordo com o PMA da SABESP de 1997, que previu a priorização de todos os recursos hídricos disponíveis na região metropolitana, há um déficit superior a $5 \%$. De modo que os reservatórios são superexplorados e mesmo quando termina o período de chuvas, nunca atingem níveis ideais (PROAM, 2005). No período de estiagem, a quantidade de água nos reservatórios é menor, o que implica em baixa dissolução dos poluentes e na piora da qualidade da água. O PMA não inclui loteamentos clandestinos e irregulares, sendo assim, várias áreas suburbanas encontram-se excluídas do planejamento de abastecimento e por isso, não recebem água tratada.

Como as empresas de abastecimento de água têm a responsabilidade de cumprir os códigos e normas da boa engenharia, atribui-se a elas a obrigação de ser proativas em realizar ou promover avaliações do perigo de contaminação para todas as suas fontes de águas subterrâneas (BANCO MUNDIAL, 2006). Isso proporcionará uma base sólida para que se recorra ao órgão local de regulamentação de meio ambiente e dos recursos hídricos para ações visando medidas de proteção, quando necessário. Mesmo nos lugares onde não existe nenhum órgão ou legislação adequada de controle da poluição, geralmente é possível que o governo local ou autoridade municipal tome medidas preventivas por decreto, no interesse maior da população local. 


\section{REFERÊNCIAS BIBLIOGRÁFICAS}

ALVES DA SILVA, M. E. P. Pescadores e Pescarias de pequena escala em comunidades locais: o caso do reservatório Billings (Alto Tietê, SP) In: Dissertação de Mestrado. Instituto de Pesca, Secretaria da Agricultura e Abastecimento do Estado de São Paulo. São Paulo. 89p. 2008.

ARAUJO, R. P. A., SHIMIZU, G.Y., BOHRER-MOREL, M.B.C., JARDIM, W. Avaliação da qualidade de sedimentos. In: ZAGATTO, P. A. e Bertoletti, E., 2006. Ecotoxicologia Aquática - Princípios e Aplicações. São Carlos, São Paulo, p. 293-326.

BANCO MUNDIAL. Proteção da qualidade da água subterrânea: um guia para empresas de abastecimento de água, órgãos municipais e agências ambientais. Traduzido por Servmar - Serviços Técnicos Ambientais Ltda, p.114, 2006. Título original:

Groundwater Quality Protection: A Guide for Water Service Companies, Municipal Authorities and Environment Agencies. (2002). Disponível em: $<$ http://siteresources.worldbank.org/INTWRD/Resources/336486-1175813625542/ Ground waterQualityProtectionGuide_Portugese.pdf.> Capturado em: 10/10/12.

BAZANTE-YAMAGUISHI, R., 2007, Análise Ecotoxicológica de viveiro de produção de tilápia (Oreochromis niloticus), utilizando o cladócero Ceriodaphnia dubia como organismo-teste. In: Dissertação de Mestrado. Instituto de Pesca. Secretaria da Agricultura e Abastecimento do Estado de São Paulo, São Paulo. 46p

BRANCATELLI, R.; FORTES, R. R\$ 3 bi depois, por que o Rio Tietê continua tão sujo? Discussões urbanas - os desafios da metrópole. C8, Cidades/Metrópole, O Estado de S. Paulo. 27 jun. 2011. São Paulo. Disponível em: < http://www.estadao.com.br/ noticias/impresso,r-3-bi-depois-por-que-o-rio-tiete-continua-tao-sujo,737316,0.htm $>$

Acesso em 12 mai. 12.

CAPOBIANCO, J.P.R.; WHATELY, M. Billings Ameaças e perspectivas para o maior reservatório de água da Região Metropolitana de São Paulo: Relatório do diagnóstico socioambiental participativo da bacia hidrográfica da Billings no período de 1989-99. Instituto Socioambiental. São Paulo. 2002. Disponível em: $<$ http://www.isa.org.br/banco_imagens/pdfs $>$ Acesso em: 10 jul. 2009.

CASTRO, P.M.G.; VERMULM JUNIOR, H.; CAMPOS, E.C.; MERCANTE, C.T.J.; BARBIERI, G.; ESTEVES, K.E.; GIAMAS, M.T.D. A pesca artesanal profissional extrativista continental no Estado de São Paulo: uma análise crítica. Textos Técnicos do Instituto de Pesca. São Paulo, 02p. 2004. Disponível em: $<$ http// www.pesca.sp.gov. br/textos.php.> Acesso em: 28 nov.2008.

CENTRO DE DOCUMENTAÇÃO ELÓY FERREIRA DA SILVA - CEDEFES. Disponível em: < http://www.cedefes.org.br/index.php?p=antigas\&Id=4678> Acesso em: 30 Ago. 2012. 
CHAMY, P. Reservas Extrativistas Marinhas como instrumento de reconhecimento do direito consuetudinário de pescadores artesanais brasileiros sobre territórios de uso comum. PROCAM/NUPAUB/USP. 24p. 2004. Disponível em: $<$ http://www.ibcperu.org/doc/isis/5275.pdf $>$ Acesso em: 10 ago. 12

CHILTON, P.J. Groundwater for small-scale irrigation: experience and prospects. Groundwater and agriculture: the inter-relationship. BGS Tec. Report, WD/95/26: 1725. 1995.

COMITÊ DA BACIA HIDROGRÁFICA DO ALTO TIETÊ. Características da UGRHI. Disponível em: <http://www.comiteat.sp.gov.br/bacia.htm\#CARACTERÍSTICAS \%20DA\%20UGRHI>. CBH-AT Acesso em: Ago. 2010.

COMPANHIA DE SANEAMENTO BÁSICO DO ESTADO DE SÃO PAULO. Diagnóstico Hidrogeológico da Região Metropolitana de São Paulo, Relatório Final. Convênio SABESP/CEPAS-IGc-USP. São Paulo, 2008

COMPANHIA DE SANEAMENTO BÁSICO DO ESTADO DE SÃO PAULO. Poços Artesianos. SABESP. Disponível em: $<$ http://site.sabesp.com.br/site/interna/Default.aspx? $\underline{\text { secaoId=104 }}>$ São Paulo, Acesso em 01 out 2013.

COMPANHIA DE TECNOLOGIA DE SANEAMENTO AMBIENTAL, 2001, Relatório de estabelecimento de valores orientadores para solos e águas subterrâneas no Estado de São Paulo. CETESB, São Paulo, 137p.

COMPANHIA DE TECNOLOGIA DE SANEAMENTO AMBIENTAL. 1993, Relatório de qualidade das águas interiores do Estado de São Paulo - 1992. São Paulo: CETESB, Série relatórios, $251 \mathrm{p}$.

COMPANHIA DE TECNOLOGIA DE SANEAMENTO AMBIENTAL. Relatório de qualidade das águas interiores do estado de São Paulo. 2003 / CETESB. São Paulo: CETESB, 2004. 273p.

COMPANHIA DE TECNOLOGIA DE SANEAMENTO AMBIENTAL. Relatório de qualidade das águas interiores do estado de São Paulo. 2005 / CETESB. São Paulo: CETESB, 2006. 488p.

COMPANHIA DE TECNOLOGIA DE SANEAMENTO AMBIENTAL. Relatório de qualidade das águas interiores do estado de São Paulo. 2006 / CETESB. São Paulo: CETESB, 2007. 327p.

CONSELHO NACIONAL DO MEIO AMBIENTE. Resolução $n^{\circ}$ 357, de 17 de março de 2005. Diário Oficial da União. Brasília: CONAMA. 23p. Disponível em: $<$ http://www.mma.gov.br/port/conama> Acesso em: 30 jun. 2009. 
CONSELHO NACIONAL DO MEIO AMBIENTE. Resolução $n^{\circ}$ 396, de 3 de abril de 2008. Diário Oficial da União. Brasília: CONAMA. 11p. Disponível em: $<$ http://www.mma.gov.br/port/conama> Acesso em: 30 jun. 2010.

COMPANHIA DE PESQUISA DE RECURSOS MINEIRAIS - CPRM. Noções Básicas sobre poços tubulares: cartilha informativa. p.22, 1998.

CUMMINS, K. W., MERRITT, R. W., ANDRADE, P. C. N. The use of invertebrate functional groups to characterize ecosystem attributes in selected streams and rivers in southeast Brazil. Stud. Neotrop. Fauna Environ. v. 40 p. 71-90, 2005.

DEPARTAMENTO DE ÁGUAS E ENERGIA ELÉTRICA - DAEE. Sistemas Aqüíferos da Região Metropolitana de São Paulo. Brasilia: DAEE. Disponível em: http:// www. daee.sp. gov.br/ index.php?option=com_content\&view $=$ frontpage\&Itemid=28. Acesso em: Ago2010.

DIAS, C.L. Critérios para projeto de rede de monitoramento de águas subterrâneas proposta de implantação na Bacia Hidrográfica do Alto Tiête, SP. Dissertação (Mestrado), Instituto de Geociências - USP. São Paulo, 159p.: il. 2005.

EMPRESA BRASILEIRA DE PESQUISA AGROPECUÁRIA - EMBRAPA. Aquífero Guarani. 2013. Disponível em: http://www.cnpma.embrapa.br/projetos/index.php3? $\underline{\mathrm{sec}=\text { guara }}$. Acesso em 10.05.13.

EMPRESA METROPOLITANA DE ÁGUAS E ENERGIA. Relatórios técnicos RT1 e RT2 - Avaliação da qualidade das águas do sistema Pinheiros-Billings com o protótipo do sistema de flotação. Fundação Centro Tecnológico de Hidráulica. São Paulo: EMAE. 108p. 2008.

FURLAN, N.; ESTEVES, K.E.; QUINÁGLIA, G.A. Environmental factors associated with fish distribution in an urban neotropical river (Upper Tietê River Basin, São Paulo, Brazil). Environ Biol Fish, 96:77-92, 2013.

HIRATA, R. \& VANIER, C. Águas Subterrâneas e Agronegócios. In: X Congresso Brasileiro de Águas Subterrâneas. 17p. 1998.

HIRATA, R. \& FERREIRA, L.M. Os aqüíferos da Bacia Hidrográfica do Alto Tiête: disponibilidade hídrica e vulnerabilidade à poluição. Revista Bras. Geociências. V.31 31(1): 43-50, março de 2001. Soc. Bras. Geologia. 2001.

HORTELLANI, M. A.; SARKIS, J. E. S.; MENEZES, L.C.B; BAZANTEYAMAGUISHI, R.; PEREIRA, A.S.A.; GARCIA, P. F. G.; MARUYAMA, L.S.; CASTRO, P.M.G. Assessment of Metal Concentration in the Billings Reservoir Sediments, São Paulo State, Southeastern Brazil. J. Braz. Chem. Soc., Vol. 24, No. 1 2013 . 
INSTITUTO BRASILEIRO DE GEOGRAFIA E ESTATÍSTICA. Estimativas de População, Estimativa Populacional de 2013. Brasília: IBGE. Disponível em: $<$ http://www.ibge.gov.br/home/estatistica/populacao/estimativa2013/estimativa_dou.shtm \%3E\%20> Acesso em 01 set. 2013.

INSTITUTO BRASILEIRO DE PROTEÇÃO AMBIENTAL - PROAM. Billings 2009 impactos ambientais. Campanha billings, eu te quero viva! São Paulo: PROAM. 19p. Disponível em: $<$ http://www.proam.org.br/documentos.asp?pagID=1 $>$ Acesso em 05 Jan. 13.

INSTITUTO DE ESTUDOS SOCIOECONÔMICOS. A água nas terras indígenas. Orçamento \& Política Sócioambiental. Ano III, n. 9.. Brasília: INESC, jun. 2004. Disponível em: $<\underline{\text { http://www.inesc. org.br/biblioteca/publicacoes/ textos/boletins/ }}$ orcamento-politica-socioambiental/boletim-no9> Acesso em 13 jul. 12.

INSTITUTO SOCIOAMBIENTAL - ISA. 2009. Disponível em: < http://www. mananciais.org.br/> Acesso em set. 11.

JESUS, J. A. O. Utilização de modelagem matemática 3D na gestão da qualidade da água em mananciais - Aplicação no reservatório Billings. Tese (Doutorado em Saúde Ambiental). Faculdade de Saúde Pública. Universidade de São Paulo. São Paulo. 142p. 2006.

LABORATÓRIO DE HABITAÇÃO E ASSENTAMENTOS HUMANOS - LABHAB. Impactos urbanísticos do Trecho Oeste do Rodoanel Mario Covas - Faculdade de Arquitetura e Urbanismo da Universidade de São Paulo, São Paulo: LABHAB, 163p. 2005. Disponivel em: $<$ http://www.usp.br/fau/depprojeto/labhab/ biblioteca/produtos/ impactos_urb_trecho este_rodoanel.pdf $>$ Acesso em 21 set. 12.

MARIANI, C. F. Reservatório Rio Grande: Caracterização limnológica da água e biodisponibilidade de metais-traço no sedimento. Dissertação (Mestrado em Ecologia de Ecossistemas Terrestres e Aquáticos). Instituto de Biociências. Universidade de São Paulo, São Paulo. 126p. 2006.

MARTINS, G.M. Efeitos da ação de cupins sobre propriedades de um perfil de solo em uma vertente da Represa Billings - São Bernardo do Campo/SP. Tese de Doutorado. Faculdade de Filosofia Letras e Ciências Humanas - Geografia. 89p.2007.

MINTE-VERA, C.V. A pesca artesanal no reservatório Billings (São Paulo). Campinas. 86p. Dissertação de Mestrado. Instituto Biologia, UNICAMP. 1997.

MOREIRA, B. CCR apresenta menor pedágio no Rodoanel, de R\$ 1,16. Portal Exame.

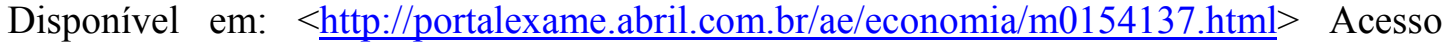
em: 24 de Agosto de 2008. 
MUNIZ, T.P. Avaliação de risco ecológico em ambientes hídricos do Estado de São Paulo. Dissertação (Mestrado em Saúde Ambiental) - Faculdade de Saúde Pública Universidade de São Paulo, São Paulo. 79p. 2004.

NÁJAR, A. Excesso de extração de água causa rachaduras gigantes no solo do México. In: BBC Mundo no México - BBC Brasil - América Latina. 2009. Disponível:< http://www.bbc.co.uk/portuguese/noticias/2009/08/090807_rachadurasmexico_is.shtml>

NUCCI, N.L.R. Aproveitamento dos recursos hídricos na Região Metropolitana de São Paulo. In São Paulo (Estado). Coordenadoria de Educação Ambiental Política e Gestão de Recursos Hídricos no Estado de São Paulo/Secretaria do Meio Ambiente, Coordenadoria de Educação. Ambiental- São Paulo: A Secretaria - Série Seminário e Debates.1993.

OLIVEIRA, T.; SARKIS, J.E.S.; ULRICH, J.C.; MENEZES, L.C.B.; CASTRO, P.M.G.; MARUYAMA, L.S.; BAZANTE-YAMAGUISHI, R.; MONTEIRO JÚNIOR, A.J. Determinação dos metais $\mathrm{Al}, \mathrm{Cd}, \mathrm{Cr}, \mathrm{Cu}, \mathrm{Hg}, \mathrm{Mg}, \mathrm{Pb}$ e $\mathrm{Zn}$ presentes em tecidos de peixes da represa Billings, São Paulo. In: XI Reunião Científica do Instituto de Pesca. p.194-196. Disponível em: <http://www.pesca.sp.gov.br/11recip2013/resumos.htm.> (2012). Acesso em 26.08.2013.

OPERADOR NACIONAL DO SISTEMA ELÉTRICO. Atualização de séries históricas de vazões - período 1931 a 2006. Rio de Janeiro: ONS, 34p. 2007.

PREFEITURA DE SÃO PAULO. Represa Guarapiranga. Disponível em: $<$ http://ww2.prefeitura.sp.gov.br/guarapiranga/capa.asp> Acesso em: 30 jan. 12.

RANZANI DE PAIVA, F.; CASTRO, P.M.G; MARUYAMA, L.S Pesca Artesanal na Represa Billings, Estado de São Paulo: uma arquelologia da existência. In: SEMINÁRIO DA AQUICULTURA E DA PESCA NO BRASIL, 2. 29 de nov. A 03 dez. 2006. Rio de Janeiro, 2006. Anais... Rio de Janeiro: 1-6p. 2006.

REINA, E. Rodoanel aterra parte da Billings: Duas estradas paralelas foram construídas dentro da água. 2007.2 Disponível em: $<$ http://txt4.jt.com.br/editorias/2007/11/23/ger-1.94.4.20071123.24.1.xml>

REITER, A.S.; ASCAR, F.; BAPTISTA, M.; BELLENZANI, M.L. (Org.) Ecoturismo e agroecologia no extremo sul de São Paulo. Secretaria Municipal de Verde e Meio Ambiente. São Paulo, 80p. 2012.

ROCHA A. A.; PEREIRA D. N., PÁDUA H. B. de, 1985, Fishing yield and chemical contamination of the water of the Billings Reservoir, S. Paulo (Brazil) Rev. Saúde Pública, vol.19, n.5, São Paulo (SP).

SAMPAIO, S.A. Quantificação de metais em águas e sedimentos do reservatório Billings por fluorescência de raios $x$ com reflexão total e radiação Sincroton (SR-TXRF). Dissertação (Mestrado). Faculdade de Engenharia Civil, Arquitetura e Urbanismo. Universidade Estadual de Campinas, São Paulo. 193p. 2007. 
SAMPAIO, T.Q. A água subterrânea no desenvolvimento social e econômico brasileiro. CPRM/SGB - Serviço Geológico do Brasil. 2012. Disponível em: http://www.abas.org/xviicongresso/download/23-10/19h30 thales_sampaio_23-10 guai curus palestra abas final.pdf

SECRETÁRIA MUNICIPAL DO VERDE E MEIO AMBIENTE - SVMA. Base cartográfica digital da Secretaria do Meio ambiente. Governo do Estado de São Paulo, Programa de Recuperação da Bacia da Billings. 1999.

SILVA, V.R. Ocupação Territorial e Qualidade da Água Subterrânea em Maciço Fraturado na Região de Itaquera, São Paulo - SP. São Paulo. Dissertação (Mestrado) Instituto de Geociências, USP, 2000.

SILVÉRIO, P.F. Bases técnico-científicas para derivação valores-guias de qualidade de sedimentos para metais: experimentos de campo e laboratório. Tese (Doutorado em Ciências da Engenharia Ambiental). Escola de Engenharia de São Carlos. Universidade de São Paulo, São Paulo. 145p. 2003.

SILVIA, I.S., ABATE, G., LICHTIG, J. MASINI, J.C. Heavy metal distribution in recent sediments of the Tietê-Pinheiros river system in São Paulo state, Brazil. Applied Geochemistry. 17, 105-116. 2002.

SOLIA, M.; FARIA, O. M.; ARAÚJO, R. Mananciais da região metropolitana de São Paulo. Sabesp. São Paulo. 18p. 2007.

TEIXEIRA, C. C. Fundação Nacional de Saúde.: A política brasileira de saúde indígena vista através de um museu. Etnográfica, Lisboa, v. 12, n. 2, nov. 2008. Disponível em $<$ http://www.scielo.gpeari.mctes.pt/scielo.php?script=sci_arttext\&pid=S0873-

$65612008000200003 \& \operatorname{lng}=$ pt\&nrm=iso $>$. Acesso em 04 mai. 2013.

THOMPSON, E.P. Costumes em comum: estudos sobre a cultura popular tradicional. São Paulo: Cia das Letras, 2002.

TRATA BRASIL. Instituto Trata Brasil divulga ranking do saneamento com avaliação dos serviços nas 81 maiores cidades do País. (2010) Disponível em: < http://www.tratabrasil.org.br/datafiles/uploads/pdfs/ranking-81-cidades-release_final.pdf $>$ Acesso em: 10 mai. 12.

TRINDADE, M. Estudo de parâmetros físicos e químicos em sedimentos da represa Rio Grande (Complexo Billings). São Paulo. SP. Tese (Doutorado). Universidade Federal de São Carlos. São Carlos. SP. 213p. 1988.

TUNDISI, J.G. Água no século XXI: Enfrentando a escassez. Rima e IEE. 247p. 2003.

UIL. H; GEER, F.C.; GEHERELS, J.C.; KLOOSTERMAN. State of art on monitoring and assessment of groundwaters. UN/ECE Task Force on Monitoring and 
Assessment. Working Programme 1996/1999. Volume 4. Lelystad, The Netherlands: Institute of Applied Geoscience. 84p, 1999.

UNITED STATES ENVIRONMENTAL PROTECTION AGENCY - USEPA. Protecting Water Resources with Smart Growth. Washington DC, 120p. 2004. Disponivel em: $<$ http://www.epa.gov/smartgrowth/pdf/waterresources_with_sg.pdf $>$ Acesso em: 05 mai. 13

VICTORINO, V. I. P. Luz e poder na dramática conquista do meio natural: a privatização dos rios paulistanos e a reflexividade sócio-ambiental. Tese de doutorado, Departamento de Sociologia, Universidade de São Paulo, 2002.

WALTER, T. 2000 Ecologia da pesca artesanal no lago Paranoá - Brasília - DF. São Carlos. 227p. (Dissertação de Mestrado. Escola de Engenharia de São Carlos, USP).

WORLD BANK. Brasil: visão panorâmica do país. 2013. Disponível em: $<$ http://www.worldbank.org/pt/country/brazil $>$ Acesso em: 05 jun. 13.

ZAGATTO, P.A.; BERTOLETTI, E. Ecotoxicologia Aquática - Princípios e Aplicações. São Carlos. Rima. 2006. 


\section{PROGRAMA AUXILIAR DE MONITORAMENTO DA QUALIDADE DE ÁGUAS - PAMQUÁ ${ }^{\circledR}$}

\subsection{Introdução}

$\mathrm{Na}$ investigação de processos, a supervisão de resultados a partir de um software capaz de armazenar um banco de dados para a aplicação de ferramentas estatísticas de controle de qualidade, cálculo de um indicador e outros subsídios para ações, podem ser aplicados na tomada de decisão.

Uma das abordagens na ánalise de dados de programas de biomonitoramento é o desenvolvimento e aplicação de índices univariados e/ou multimétricos (GERRITSEN, 1995). As análises univariadas apresentam uma maneira da escolha do teste estatístico a ser utilizado quando temos apenas uma variável como resposta (análises univariadas) e esta tem natureza quantitativa (FAWLER \& COHEN, 1990). Em casos onde a resposta é quantitativa, mas discreta (dados de contagem), testes mais adequados são baseados na distribuição de Poisson, embora a maioria dos testes são atribuidos à distribuição Normal (média maior que 5). Os índices multimétricos são aqueles em que observam-se diversas variáveis como resposta. A situação mais simples em biomonitoramento é quando há o interesse não em uma espécie em particular ou uma métrica composta (por exemplo índice de diversidade), mas nas respostas das várias espécies.

Baptista, et al., (2007) descrevem abordagens em que (1) selecionam as ações conhecidas por perturbações antrópicas ou naturais, que representam uma alteração no meio ambiente; (2) estipulam valores (escores) para intervalos destas variáveis; (3) somam os escores e (4) de acordo com a somatória de escores, categorizam a avaliação, por exemplo: ruim, regular, bom e muito bom (PLAFKIN et al., 1989, UNDERWOOD, 1997; CARTER \& RESH, 2001).

Melo \& Hepp (2008) apontaram como estratégia a replicação temporal, replicações ao longo de anos para as épocas específicas (por exemplo, verões) como sendo algo factível para um programa de monitoramento, mas de difícil execução em estudos mais pontuais. A sugestão dada por esses autores é possuir objetivos mais restritos (uma época do ano), com réplicas mais adequadas para o estudo. 
No contexto do biomonitoramento em ambientes aquáticos, cuja a escala de interesse é o manancial escolhido, com seus afluentes (rios, riachos e formação de lagos), podemos incluir outros aspectos, como o planejamento das coletas, o local impactado e o local controle.

Dentro desses apectos, o Programa Auxiliar de Monitoramento da Qualidade

de Água - PAMQUÁ ${ }^{\circledR}$ - foi desenvolvido durante esta tese para apoiar os esforços ambientais focados em gerenciar a qualidade da água para consumo humano, além de servir como base de dados indicadora, de suporte gestorial, de subsídios e de tomada de decisão quando tratamos de efeitos que causam impacto ao ambiente.

Sendo o PAMQUÁ ${ }^{\circledR}$ uma ferramenta estatística de suporte e tomada de decisão, aplicou-se essa ferramenta em dados históricos de monitoramento anual de águas superficiais, produzidos pela Companhia Ambiental do Estado de São Paulo (CETESB) e que estão disponíveis em domínio público desde o ano 2000 sob a forma de publicações/relatórios (CETESB, 2013). Esta ferramenta proporciona maior objetividade na interpretação dos resultados analíticos e à tomada de decisões.

\subsection{Elaboração da Arquitetura do PAMQUÁ ${ }^{\circledR}$}

Foram estipulados três fatores principais relevantes para o delineamento de um problema de contaminação ambiental: fator A, B e C e níveis de 1 a 10 e que dão origem ao produto final. Os valores de cada fator e seus níveis estão detalhados na TAB. 3.1.

Partindo da problemática ambiental, o estudo identificou o histórico de concentração do metal alumínio em águas de classe 2 , correlacionando seu resultado com o Valor Máximo Permitido (VMP) de $0,1 \mathrm{mg} / \mathrm{l}$, de acordo com a portaria 357/05, revisada pela 430/11 do CONAMA. 
TABELA 3.1. Faixas de valores para os três fatores de decisão.

\begin{tabular}{|c|c|c|c|}
\hline Nível (n) & $\begin{array}{c}\text { Histórico de } \\
\text { Não conformidade }(\%)\end{array}$ & $\begin{array}{l}\text { Último resultado } \\
(\mathrm{mg} / \mathrm{L})^{1}\end{array}$ & Frequência dos testes \\
\hline 1 & $0-10,0$ & $\leq 0,002$ & Não regulares \\
\hline 2 & $10,1-20,0$ & $0,003-0,005$ & Bienal \\
\hline 3 & $20,1-30,0$ & $0,006-0,014$ & Anual \\
\hline 4 & $30,1-40,0$ & $0,015-0,037$ & Semestral \\
\hline 5 & $40,1-50,0$ & $0,038-0,100$ & Trimestral \\
\hline 6 & $50,1-60,0$ & $0,101-0,272$ & Bimestral \\
\hline 7 & $60,1-70,0$ & $0,273-0,740$ & Mensal \\
\hline 8 & $70,1-80,0$ & $0,741-2,012$ & Semanal \\
\hline 9 & $80,1-90,0$ & $2,013-5,740$ & Diariamente \\
\hline \multirow[t]{2}{*}{10} & $90,1-100,0$ & $5,741-14,87$ & De hora em hora \\
\hline & Fator $[\mathrm{A}]$ & Fator $[\mathrm{B}]$ & Fator $[\mathrm{C}]$ \\
\hline
\end{tabular}

- Fator [A] é histórico de não conformidade. Indica o percentual dos resultados da análise que mostraram valores acima do máximo permitido. Este fator tem função de dar peso ao histórico.

- Fator [B] é o último resultado publicado no relatório de domínio público. Indica uma tendência, podendo estar em ascensão ou queda da qualidade da água monitorada. Este fator também tem a função de dar ao resultado peso momentâneo.

- Fator [C] é a frequência dos testes. Quanto maior a frequência, maior o grau de monitoramento e, portanto, será maior o nível de informação disponível para a tomada de decisão. Essa função fornece um peso para o nível de segurança.

Para determinar o fator [B] foi utilizando a equação (E1), abaixo:

$$
\mathrm{B}=0,000675 \cdot e^{\mathrm{n}}
$$

\footnotetext{
${ }^{1}$ Valores adaptados do relatório anual da CETESB, onde o valor máximo permitido (VMP) para alumínio dissolvido para águas de classe 2 é de $0,100 \mathrm{mg} / 1$, onde as amostragens são realizadas bimestralmente.
} 
O principal objetivo de utilizar a função exponencial (ou o número de Euler ou constante de Euler) seria a de representar situações em que a taxa de variação é consideravelmente grande, proporcionando neste estudo uma faixa maior de valores, incorporando de forma mais abrangente uma situação real em que possivelmente pode ocorrer uma contaminação. Dessa forma, foi possível ter valores de alumínio dissolvido de $\leq 0,002$ (valor mínimo) até $14,87 \mathrm{mg} / 1$ (valor máximo), sendo este último valor, 150 vezes maior do que o limite estabelecido para este metal.

Além de ser uma das mais importantes funções da matemática, a função está ligada ao fato de surgir de forma espontânea em diversas situações onde envolvem aumento ou diminuição de grandezas e as várias possibilidades de aplicações, em estudos de fenômenos que evoluem exponencialmente, tais como, juros contínuos, decaimento radiativo, reprodução de bactérias, resfriamento e aquecimento, crescimento populacional, pressão atmosférica e escala Richter (MESQUITA, 2013).

O valor da constante $(0,000675)$ foi ajustado empiricamente para que o nível (n) seja igual a 5, ou seja, quando o resultado da análise estiver com valor entre 0,038 e 0,1 $\mathrm{mg} / \mathrm{l}$. Conceitualmente, qualquer resultado acima do nível 5 representará que o mesmo está acima do limite permitido. Vale lembrar que o valor de referência para o alumínio total, de acordo com a Portaria 2914/11 do Ministério da Saúde para a água potável é de 0,2 mg/l e o valor de referência para o alumínio dissolvido às águas de classe 2 , de acordo com a Resolução 430/11 do CONAMA é 0,1 mg/l.

A pontuação final é calculada usando os níveis $n$, para os fatores $A, B$ e $C$, mostrados na equação (E2).

$$
\text { Pontuação }=\mathrm{A}^{2} \cdot \mathrm{B}^{2} \cdot \mathrm{C}
$$

Os fatores $\mathrm{A}$ e $\mathrm{B}$, histórico de não conformidade e últimos resultados, respectivamente, receberam peso elevado ao quadrado devido ambos serem fatores quantitativos e representam informações sobre o real impacto da qualidade da água em detrimento ao fator $\mathrm{C}$ (frequência de monitoramento) que é considerado um fator qualitativo. Dessa forma, o histórico de não conformidade, valor dado em percentagem e o último resultado dado pelo valor em $\mathrm{mg} / \mathrm{l}$ são ditos fatoriais. Como somente há dois níveis de cada fator, eles nos dão o menor número de tratamento. A faixa de pontuação final está entre 1 e 100.000. Portanto, a pontuação de alerta identificará cinco novos níveis como apresentado na TAB. 3.2. 
TABELA 3.2. Níveis de alertas e pontuações.

\begin{tabular}{ccc}
\hline $\mathrm{N}$ & Nível de Alerta & Faixa de Pontuação \\
\hline 1 & Mínimo & $1-366$ \\
2 & Limítrofe & $367-1.991$ \\
3 & Atenção & $1.992-8.120$ \\
4 & Perigo & $8.121-29.430$ \\
5 & Máximo & $29.431-100.000$ \\
\hline
\end{tabular}

A faixa do nível de alerta foi definido usando a equação (E3), sendo que para $\mathrm{n}=0$, a faixa de pontuação é igual a 0 e para $\mathrm{n}=5$, a faixa de pontuação é igual a 100.000, obtida através da base exponencial. A constante de ajuste $(134,75894)$ foi definida de forma empírica, visando atender estas premissas.

$$
\text { Faixa da Pontuação }=134,75894 \cdot n \cdot \mathrm{em}
$$

Detalhando os níveis de alerta, podemos especificar seus riscos e recomendações de acordo com a TAB. 3.3: 
TABELA 3.3. Descrição dos níveis de alerta, seus riscos e recomendações.

\begin{tabular}{|c|c|c|}
\hline $\begin{array}{l}\text { Nível de } \\
\text { alerta }\end{array}$ & Risco & Recomendação \\
\hline Mínimo & $\begin{array}{l}\text { Nenhum risco para saúde } \\
\text { humana }\end{array}$ & $\begin{array}{l}\text { Não há recomendações a serem } \\
\text { implementadas. }\end{array}$ \\
\hline Limítrofe & $\begin{array}{l}\text { Baixo risco à saúde } \\
\text { humana. }\end{array}$ & $\begin{array}{l}\text { Monitoramento adicional é } \\
\text { requerido para confirmação dos } \\
\text { resultados }\end{array}$ \\
\hline Atenção & $\begin{array}{l}\text { Potencial risco à saúde } \\
\text { humana }\end{array}$ & $\begin{array}{l}\text { Requer atenção e esforços mínimos } \\
\text { para remediação da contaminação }\end{array}$ \\
\hline Perigo & $\begin{array}{l}\text { Risco iminente à saúde } \\
\text { humana }\end{array}$ & $\begin{array}{l}\text { Requer maiores esforços para } \\
\text { remedição da contaminação }\end{array}$ \\
\hline Máximo & Fora do controle & $\begin{array}{l}\text { Alto risco à saúde humana. Requer } \\
\text { intervenção imediata e um plano } \\
\text { emergencial é altamente } \\
\text { recomendado. }\end{array}$ \\
\hline
\end{tabular}

Fonte: Adaptado de AIAG, 1993.

A fim de demonstrar como a ferramenta de decisão atua, um exemplo é mostrado na sequência.

Exemplo:

- Dados sobre o histórico de não conformidade: 70\% $(\mathrm{A}=7)$;

- Último Resultado: <0,25 mg/l $(B=6)$;

- Frequência de monitoramento: bimestral $(\mathrm{C}=6)$

Cálculo: Pontuação $=\mathrm{A}^{2} \cdot \mathrm{B}^{2} \cdot \mathrm{C}=7^{2} \cdot 6^{2} \cdot 6=10.584$

Nível de Alerta $=4$ (Perigo) 


\subsection{Objetivos}

O objetivo principal deste trabalho foi criar níveis de alerta sobre a qualidade da água através da aplicação da ferramenta estatística PAMQUÁ ${ }^{\circledR}$.

O objetivo específico compreende a aplicação da ferramenta PAMQUÁ ${ }^{\circledR} \mathrm{em}$ dados de qualidade de água disponíveis em domínio público: o caso de um reservatório de abastecimento da cidade de São Paulo com investigação histórica a partir de dados publicados sobre a frequência de monitoramento e os valores não conformes, para redução de incertezas de tendências para uma tomada de decisão sobre o estudo do metal alumínio nesta tese.

\subsection{Materiais e métodos}

As fontes de dados utilizadas nessa parte do trabalho foram provenientes dos relatórios anuais da CETESB e de outras publicações (CETESB, 2005-09; SAMPAIO, 2007; SABESP, 2008).

Essa ferramenta foi adaptada ao conceito semelhante àquela conhecida por Modo de Falha e Análise do Efeito (Failure Mode and Effect Analysis - FMEA), tendo como produto final um nível de alerta para que decisões justificadas pelos resultados da contaminação sejam tomadas (AIAG,1993).

Desse modo, verificaram-se todos os metais requisitados pelos órgãos regulamentadores, em determinados pontos da represa, especificamente na região do extremo sul, onde está localizado o bairro Ilha do Bororé. Esse ponto específico do estudo é um local habitado, embora seja uma Área de Proteção Ambiental e Área de Preservação Permanente (APA/APP), diversas comunidades estão presentes, como por exemplo, a comunidade pesqueira artesanal que utiliza dos recursos do manancial para sua subsistência, demonstrando maior potencial de riscos de contaminação quando o saneamento básico é inexistente, isso inclui falta de tratamento de água e esgoto aos moradores. A TAB. 3.4., apresenta todos os metais evidenciados nas fontes de dados, sendo que as maiores concentrações dos metais foram destacadas, conforme o ano de estudo. A cor amarela destaca os resultados acima do VMP. 
TABELA 3.4. Concentração de metal total e dissolvidos ( $\mathrm{mg} / \mathrm{l})$ em amostras de águas superficiais: pontos de monitoramento na represa Billings, 2005-2007.

\begin{tabular}{|c|c|c|c|c|c|c|c|c|c|c|c|c|c|c|c|c|c|}
\hline Local & $\begin{array}{c}\text { Ano/ } \\
\text { Coleta }\end{array}$ & Alumínio & $\begin{array}{l}\text { Alumínio } \\
\text { dissolv. }\end{array}$ & $\begin{array}{c}\text { Arsênio } \\
\text { total }\end{array}$ & $\begin{array}{l}\text { Cádmio } \\
\text { total }\end{array}$ & $\begin{array}{c}\text { Chumbo } \\
\text { total }\end{array}$ & $\begin{array}{c}\text { Cobre } \\
\text { total }\end{array}$ & $\begin{array}{l}\text { Cobre } \\
\text { dissolv. }\end{array}$ & $\begin{array}{c}\text { Cromo } \\
\text { total }\end{array}$ & $\begin{array}{l}\text { Ferro } \\
\text { total }\end{array}$ & $\begin{array}{c}\text { Ferro } \\
\text { dissolv. }\end{array}$ & $\underset{\text { total }}{\text { Manganês }}$ & $\begin{array}{l}\text { Manganês } \\
\text { dissolv. }\end{array}$ & $\begin{array}{c}\text { Mercúrio } \\
\text { total }\end{array}$ & $\begin{array}{c}\text { Níquel } \\
\text { total }\end{array}$ & $\begin{array}{c}\text { Zinco } \\
\text { total }\end{array}$ & Fonte \\
\hline \multirow{2}{*}{ Bororé } & 2005 & 0,370 & n.d. & n.d. & $\mathrm{i}<0,005$ & $<0,100$ & n.d. & $<0,01$ & $<0,01$ & 0,37 & n.d. & 0,080 & n.d. & $<0,0001$ & $<0,020$ & 0,030 & $\begin{array}{c}\text { CETESB } \\
\text { (2006) }\end{array}$ \\
\hline & 2006 & 0,250 & 0,15 & n.d. & $<0,0001$ & 0,010 & n.d. & 0,02 & 0,010 & 0,35 & n.d. & 0,100 & n.d. & $<0,0002$ & $<0,020$ & 0,080 & $\begin{array}{c}\text { CETESB } \\
\text { (2007) }\end{array}$ \\
\hline Bororé $\mathrm{ds}^{\mathrm{ds}}$ & \multirow{2}{*}{2006} & n.d. & n.d. & n.d. & n.d. & 0,418 & 0,308 & n.d. & 2,307 & n.d. & n.d. & 0,137 & n.d. & n.d. & 0,027 & 0,297 & \multirow{2}{*}{$\begin{array}{c}\text { SAMPAIO } \\
(2007)\end{array}$} \\
\hline Bororéas & & 0,243 & n.d. & n.d. & n.d. & 0,334 & 0,314 & n.d. & 1,403 & n.d. & n.d. & 0,337 & n.d. & n.d. & 0,369 & 0,210 & \\
\hline Taquacetuba & 2006 & 0,180 & 0,26 & 0,26 & $\mathrm{i}<0,005$ & $\mathrm{i}<0,100$ & $<0,01$ & 0,19 & 0,020 & 0,43 & $<0,10$ & 0,060 & n.d. & $<0,0002$ & 0,030 & 0,080 & $\begin{array}{c}\text { CETESB } \\
\text { (2007) }\end{array}$ \\
\hline Taquacetuba $\mathrm{a}^{\mathrm{ds}}$ & \multirow{2}{*}{2006} & n.d. & n.d. & n.d. & n.d. & 0,329 & 0,016 & n.d. & 0,142 & n.d. & n.d. & 0,109 & n.d. & n.d. & 0,014 & 0,674 & \multirow{2}{*}{$\begin{array}{c}\text { SAMPAIO } \\
(2007)\end{array}$} \\
\hline Taquacetubass & & 1,316 & n.d. & n.d. & n.d. & 0,428 & 0,059 & n.d. & 0,282 & n.d. & n.d. & 0,151 & n.d. & n.d. & 0,031 & 0,083 & \\
\hline Pedreiras & 2006 & n.d. & n.d. & n.d. & n.d. & 0,969 & 0,142 & n.d. & 9,774 & n.d. & n.d. & n.d. & n.d. & n.d. & $\begin{array}{c}< \\
0,00004\end{array}$ & 24,765 & \multirow{2}{*}{$\begin{array}{c}\text { SAMPAIO } \\
(2007)\end{array}$} \\
\hline Alvarengas & 2006 & n.d. & n.d. & n.d. & n.d. & 0,331 & 0,0048 & n.d. & 0,214 & n.d. & n.d. & n.d. & n.d. & n.d. & 0,004 & 0,184 & \\
\hline Bororé & 2007 & n.d. & 1,77 & n.d. & 0,0002 & 0,008 & n.d. & $<0,009$ & $<0,02$ & n.d. & $<0,10$ & 0,130 & n.d. & $<0,0002$ & $<0,02$ & $<0,04$ & $\begin{array}{c}\text { CETESB } \\
(2008)\end{array}$ \\
\hline Bororé & 2007 & n.d. & n.d. & $<0,01$ & 0,0015 & $<0,005$ & $<0,02$ & n.d. & $<0,003$ & 0,15 & $<0,03$ & 0,020 & $<0,02$ & $<0,0005$ & $<0,0057$ & $<0,05$ & $\begin{array}{c}\text { SABESP } \\
(2008)\end{array}$ \\
\hline VMP & & -- & 0,10 & 0,01 & 0,001 & 0,01 & -- & 0,009 & 0,05 & -- & 0,30 & 0,100 & -- & 0,0002 & 0,0250 & 0,180 & $\begin{array}{c}\text { CONAMA } \\
357 / 05\end{array}$ \\
\hline
\end{tabular}

i - Conformidade definida quanto ao limite da classe, devido a análise laboratorial não ter atingido os limites legais; a e d - Códigos relativos à travessia das balsas no sentido SBC à São Paulo, “antes" e "depois"; s - Período seco. n.d. - não determinado ; Cor amarela destaca valores acima do VMP. 
Sampaio (2007) apresentou resultados de metais pesados em maior teor que nos relatórios da CETESB em mesmo ano/locais de amostragem (Bororé), caracterizando o período de estiagem (seco) e à aplicação da técnica de Fluorescência de Raio X com Reflexão Total e excitação por Radiação Síncrotron (SR-TXRF), diferenciando sua metodologia analítica de detecção de metal dada por Espectrofotometria de Absorção Atômica por forno de grafite (AAS) e Espectrofotometria óptica de emissão com plasma de argônio (ICP-OES), de acordo com os métodos 3113 e 3120-B da CETESB, respectivamente.

$\mathrm{Na}$ sequência deste estudo, apenas os relatórios da CETESB foram escolhidos e três pontos de amostragens de águas superficiais da represa Billings melhor documentados para o estudo de caso, cujo foco é o entendimento da dinâmica dos resultados dentro de um cenário específico. Seus nomes e locais estão listados na TAB. 3.5.

TABELA 3.5. Pontos de Amostragem - represa Billings (São Paulo, Brasil).

\begin{tabular}{cc}
\hline Ponto & Local \\
\hline BILL 02100 & No meio do corpo central, na direção do braço do Bororé. \\
BILL 02900 & Próximo à barragem reguladora Billings-Pedras (Summit Control). \\
BILL 02500 & No meio do corpo central, sob a ponte da rodovia dos Imigrantes (SP). \\
\hline
\end{tabular}

Fonte: Adaptado de CETESB (2001).

A espécie química alumínio (Al) foi selecionada como elemento para esta avaliação, devido ocorrência de resultados acima do VMP durante os anos de 2000 a 2012 , no ponto BILL 02100 (TAB. 3.6.).

Os valores máximos para cada ano foram resumidos a partir de relatórios publicados durante o período de 2000 a 2012 da CETESB, disponíveis na internet (CETESB, 2001-13). Esses valores foram comparados com os Valores Máximos Permitidos (VMP) para águas doce, superficiais, classe 2, de acordo com as portarias 20/86, 357/05 e 430/11 do CONAMA. Nota-se que durante os anos, a portaria sofreu alterações. O VMP estipulado pela portaria 20/86 do CONAMA ao metal era de $0,1 \mathrm{mg} / \mathrm{l}$ de alumínio total. A partir de 2005, estabelecido pela portaria 357/05 do CONAMA, o VMP sofreu alteração para $0,1 \mathrm{mg} / 1$ de alumínio dissolvido e continua sendo requerido pela revisão da portaria 430/11.

O processo de filtração é um pré-tratamento amostral empregado para avaliar metais em sua forma dissolvida, ou seja, o metal em um determinado estado de agregação 
que não fica retido em um corpo filtrante com porosidade de $0,45 \mu \mathrm{m}$ e que compreende íons livres, complexos inorgânicos e complexos orgânicos de baixo peso molecular (USEPA, 1996), o que irá caracterizar a diferença dada pela concentração de um metal total. $\mathrm{Na}$ TAB. 3.7. são apresentados os resultados históricos dos três pontos de monitoramento, além do percentual de não conformidade. 
TABELA 3.6. Levantamento histórico dos valores máximos (VM) encontrado aos 11 metais (mg/l) na água superficial da represa Billings.

\begin{tabular}{|c|c|c|c|c|c|c|c|c|c|c|c|c|c|c|c|c|c|}
\hline Local & $\begin{array}{l}\text { Ano/ } \\
\text { Coleta }\end{array}$ & Alumínio & $\begin{array}{l}\text { Alumínio } \\
\text { dissolvido }\end{array}$ & $\begin{array}{c}\text { Arsênio } \\
\text { total }\end{array}$ & $\begin{array}{c}\text { Cádmio } \\
\text { total }\end{array}$ & $\begin{array}{c}\text { Chumbo } \\
\text { total }\end{array}$ & $\begin{array}{c}\text { Cobre } \\
\text { total }\end{array}$ & $\begin{array}{c}\text { Cobre } \\
\text { dissolvido }\end{array}$ & $\begin{array}{c}\text { Cromo } \\
\text { total }\end{array}$ & $\begin{array}{c}\text { Ferro } \\
\text { total }\end{array}$ & $\begin{array}{c}\text { Ferro } \\
\text { dissolvido }\end{array}$ & $\begin{array}{l}\text { Manganês } \\
\text { total }\end{array}$ & $\begin{array}{l}\text { Manganês } \\
\text { dissolvido* }\end{array}$ & $\begin{array}{l}\text { Mercúrio } \\
\text { total }\end{array}$ & $\begin{array}{l}\text { Níquel } \\
\text { total }\end{array}$ & $\begin{array}{c}\text { Zinco } \\
\text { total }\end{array}$ & Fonte \\
\hline \multirow{13}{*}{$\begin{array}{l}\text { BILL } \\
02100\end{array}$} & 2000 & 0,76 & n.d. & n.d. & 0,0050 & 0,080 & 0,02 & n.d. & $<0,05$ & 0,39 & n.d. & 0,06 & n.d. & $<0,001$ & $<0,01$ & 0,01 & $\begin{array}{c}\text { CETESB } \\
(2001)\end{array}$ \\
\hline & 2001 & 0,43 & n.d. & n.d. & 0,0010 & 0,040 & 0,01 & n.d. & $<0,05$ & 0,43 & n.d. & 0,06 & n.d. & 0,0005 & 0,02 & 0,02 & $\begin{array}{c}\text { CETESB } \\
(2002)\end{array}$ \\
\hline & 2002 & 0,15 & n.d. & n.d. & $<0,0010$ & $\mathrm{i}<0,10$ & $<0,01$ & n.d. & $<0,05$ & 1,15 & n.d. & 0,40 & n.d. & 0,007 & $<0,01$ & 0,02 & $\begin{array}{c}\text { CETESB } \\
(2003)\end{array}$ \\
\hline & 2003 & 0,20 & n.d. & n.d. & $\mathrm{i}<0,010$ & $\mathrm{i}<0,10$ & $<0,01$ & n.d. & $<0,05$ & 0,31 & n.d. & 0,10 & n.d. & $\mathrm{i}<0,0005$ & $<0,02$ & 0,09 & $\begin{array}{l}\text { CETESB } \\
\text { (2004) }\end{array}$ \\
\hline & 2004 & 0,15 & n.d. & n.d. & $\mathrm{i}<0,005$ & $\mathrm{i}<0,10$ & $<0,01$ & n.d. & $<0,01$ & 0,29 & n.d. & 0,10 & n.d. & $\mathrm{i}<0,001$ & $<0,02$ & 0,08 & $\begin{array}{c}\text { CETESB } \\
(2005)\end{array}$ \\
\hline & 2005 & 0,70 & n.d. & n.d. & $\mathrm{i}<0,005$ & $\mathrm{i}<0,10$ & $<0,01$ & n.d. & $<0,01$ & 0,37 & n.d. & 0,08 & n.d. & $<0,0001$ & $<0,02$ & 0,03 & $\begin{array}{c}\text { CETESB } \\
(2006)\end{array}$ \\
\hline & 2006 & 0,25 & 0,15 & n.d. & $\mathrm{i}<0,005$ & $\mathrm{i}<0,10$ & 0,02 & 0,010 & 0,01 & 0,35 & $<0,1$ & 0,10 & n.d. & $<0,0002$ & $<0,02$ & 0,08 & $\begin{array}{c}\text { CETESB } \\
(2007)\end{array}$ \\
\hline & 2007 & n.d. & 1,77 & n.d. & 0,0002 & 0,008 & n.d. & $<0,009$ & $<0,02$ & n.d. & $<0,1$ & 0,13 & n.d. & $<0,0002$ & $<0,02$ & 0,05 & $\begin{array}{c}\text { CETESB } \\
(2008)\end{array}$ \\
\hline & 2008 & 0,36 & 0,15 & $<0,002$ & 0,0010 & $<0,010$ & $<0,01$ & $<0,009$ & $<0,02$ & 0,67 & $<0,1$ & 0,18 & n.d. & 0,007 & $<0,02$ & 0,06 & $\begin{array}{c}\text { CETESB } \\
(2009)\end{array}$ \\
\hline & 2009 & 0,22 & $<0,10$ & $<0,002$ & $<0,001$ & $<0,010$ & $<0,01$ & $<0,009$ & $<0,02$ & 0,37 & $<0,1$ & 0,13 & n.d. & $<0,0002$ & $<0,02$ & 0,07 & $\begin{array}{c}\text { CETESB } \\
(2010)\end{array}$ \\
\hline & 2010 & 0,13 & $<0,10$ & $<0,002$ & 0,0006 & 0,020 & $<0,01$ & $<0,009$ & $<0,02$ & 0,21 & $<0,1$ & 0,07 & n.d. & $<0,0002$ & $<0,02$ & $<0,02$ & $\begin{array}{c}\text { CETESB } \\
(2011)\end{array}$ \\
\hline & 2011 & 0,40 & $<0,10$ & n.d. & 0,0050 & $<0,005$ & 0,01 & $<0,009$ & $<0,02$ & 0,29 & $<0,1$ & 0,07 & n.d. & 0,0004 & $<0,02$ & 0,06 & $\begin{array}{c}\text { CETESB } \\
(2012)\end{array}$ \\
\hline & 2012 & 0,14 & $<0,10$ & n.d. & $<0,0007$ & $<0,009$ & $<0,01$ & $<0,009$ & $<0,02$ & 0,46 & $<0,1$ & 0,07 & n.d. & $<0,0002$ & $<0,02$ & 0,05 & $\begin{array}{c}\text { CETESB } \\
(2013)\end{array}$ \\
\hline $\begin{array}{l}\mathrm{VMP} / \\
\mathrm{VM}^{* *}\end{array}$ & & $0,10^{*}$ & 0,10 & 0,01 & 0,0010 & 0,010 & -- & 0,009 & 0,05 & -- & 0,3 & 0,10 & 1,0 & 0,0002 & 0,025 & 0,18 & $\begin{array}{c}\text { CONAMA } \\
20 / 86^{*} 357 / 05 \\
\text { e } 430 / 11^{* *}\end{array}$ \\
\hline
\end{tabular}

VMP: valor máximo permitdo; n.d: não determinado; VM: valor máximo para efluentes; i - Conformidade definida quanto ao limite da classe, devido a análise laboratorial não ter atingido os limites legais. 
TABELA 3.7 Valor máximo anual do metal alumínio nos pontos de monitoramento da represa Billings, adaptado de anexos CETESB (2000-12).

\begin{tabular}{|c|c|c|c|c|c|c|c|c|c|c|c|c|c|c|}
\hline \multirow{2}{*}{$\begin{array}{c}\text { Portaria } \\
\text { Localização }\end{array}$} & \multirow{2}{*}{$\begin{array}{l}\text { CONAMA } \\
\text { Parâmetros }\end{array}$} & \multicolumn{5}{|c|}{$\begin{array}{c}20 / 86 \\
\text { VMP: } 0,1 \mathrm{mg} / \mathrm{l}-\text { alumínio total }\end{array}$} & \multicolumn{6}{|c|}{$\begin{array}{c}357 / 05 \\
\text { VMP: 0,1 mg/l - alumínio dissolvido }\end{array}$} & \multicolumn{2}{|c|}{\begin{tabular}{|c|}
$430 / 11$ \\
VMP: $0,1 \mathrm{mg} / \mathrm{l}$ - alumínio dissolvido
\end{tabular}} \\
\hline & & 2000 & 2001 & 2002 & 2003 & 2004 & 2005 & 2006 & 2007 & 2008 & 2009 & 2010 & 2011 & 2012 \\
\hline \multirow[t]{4}{*}{ BILL02500 } & $\begin{array}{l}\text { Último resultado (Valor } \\
\text { Max. Anual) }\end{array}$ & 0,19 & 0,15 & 0,19 & 0,19 & 0,38 & 0,46 & 0,49 & 3,01 & $<0,1$ & 0,11 & 0,11 & $<0,1$ & $<0,1$ \\
\hline & $\begin{array}{l}N^{o} \text { de resultados acima do } \\
\text { limite }\end{array}$ & 1 & 3 & 2 & 2 & 3 & 4 & 2 & 1 & 0 & 1 & 1 & 0 & 0 \\
\hline & $\begin{array}{l}\mathrm{N}^{\mathrm{o}} \text { de monitoramentos } \\
\text { executados }\end{array}$ & 6 & 6 & 6 & 6 & 6 & 6 & 4 & 6 & 6 & 6 & 6 & 4 & 4 \\
\hline & $\begin{array}{l}\text { Percentual de não- } \\
\text { conformidade }\end{array}$ & $17 \%$ & $33 \%$ & $33 \%$ & $33 \%$ & $37 \%$ & $42 \%$ & $43 \%$ & $39 \%$ & $35 \%$ & $33 \%$ & $31 \%$ & $29 \%$ & $28 \%$ \\
\hline \multirow[t]{4}{*}{ BILL02900 } & $\begin{array}{l}\text { Último resultado (Valor } \\
\text { Max. Anual) }\end{array}$ & 0,35 & 0,21 & 0,11 & 0,38 & 0,18 & 0,46 & 0,23 & 1,93 & $<0,1$ & $<0,1$ & $<0,1$ & $<0,1$ & $<0,1$ \\
\hline & $\begin{array}{l}N^{o} \text { de resultados acima do } \\
\text { limite }\end{array}$ & 3 & 3 & 1 & 3 & 3 & 3 & 2 & 2 & 0 & 0 & 0 & 0 & 0 \\
\hline & $\begin{array}{l}\mathrm{N}^{\circ} \text { de monitoramentos } \\
\text { executados }\end{array}$ & 6 & 6 & 5 & 6 & 6 & 6 & 4 & 6 & 6 & 6 & 6 & 4 & 4 \\
\hline & $\begin{array}{l}\text { Percentual de não- } \\
\text { conformidade }\end{array}$ & $50 \%$ & $50 \%$ & $41 \%$ & $43 \%$ & $45 \%$ & $46 \%$ & $46 \%$ & $44 \%$ & $39 \%$ & $35 \%$ & $32 \%$ & $30 \%$ & $28 \%$ \\
\hline \multirow[t]{3}{*}{ BILL02100 } & $\begin{array}{l}\text { Último resultado (Valor } \\
\text { Max. Anual) }\end{array}$ & 0,76 & 0,43 & 0,15 & 0,2 & 0,15 & 0,7 & 0,15 & 1,77 & 0,15 & $<0,1$ & 0,11 & $<0,1$ & $<0,1$ \\
\hline & $\begin{array}{l}N^{o} \text { de resultados acima do } \\
\text { limite }\end{array}$ & 2 & 2 & 2 & 4 & 2 & 4 & 1 & 1 & 1 & 0 & 2 & 0 & 0 \\
\hline & $\begin{array}{l}\mathrm{N}^{\mathrm{o}} \text { de monitoramentos } \\
\text { executados }\end{array}$ & 6 & 6 & 6 & 6 & 6 & 6 & 4 & 7 & 6 & 6 & 6 & 4 & 4 \\
\hline \multicolumn{2}{|c|}{ Percentual de não-conformidade } & $33 \%$ & $33 \%$ & $33 \%$ & $42 \%$ & $40 \%$ & $44 \%$ & $43 \%$ & $38 \%$ & $36 \%$ & $32 \%$ & $32 \%$ & $30 \%$ & $29 \%$ \\
\hline
\end{tabular}


Conforme os valores apresentados na TAB. 3.7 - item percentual de não conformidade - equação (E4) é acumulativo durante o período de 12 anos consecutivos, conforme dados adaptados dos relatórios anuais da CETESB.

(E4) \% não - conformidade acumulado $=\frac{\sum_{a n o=0}^{n} \text { resultados acima do limite }}{\sum_{a n o=0}^{n} \text { monitoramentos realizados }}$

\subsection{Resultados e discussão}

Com a utilização do programa PAMQUÁ ${ }^{\circledR}$ pode-se avaliar de maneira gráfica os resultados dos relatórios anuais disponíveis pela CETESB.

Observa-se que há muitas flutuações nos resultados anuais, visto que as condições de qualidade da água sofrem perturbações (naturais ou antropogênicas).

Entre as coletas de um ano específico, vale ressaltar o percentual de Não Conformidade Acumulado (NCA), onde é possível verificar uma tendência de queda de resultados. Os picos de NCA nos pontos BILL02500 e BILL02100 estão na faixa de 40 a $45 \%$ e foram registrados durante os anos de 2003 e 2006, os quais são claramente verificados no gráfico da FIG. 3.1. Após 2006, percebe-se nestes pontos uma tendência de queda chegando aos 30\% de NCA em 2011. O ponto BILL02900 apresentou desde o início do monitoramento uma tendência de queda, sendo que no ano 2000 registrou $50 \%$ de NCA e encontra-se no ano 2011 no mesmo nível de NCA que os demais pontos. Estas porcentagens são acumulativas desde o primeiro dado disponível (CETESB, 2001-13) e informa o histórico sobre cada ponto estudado desde os anos 2000 a 2012. 


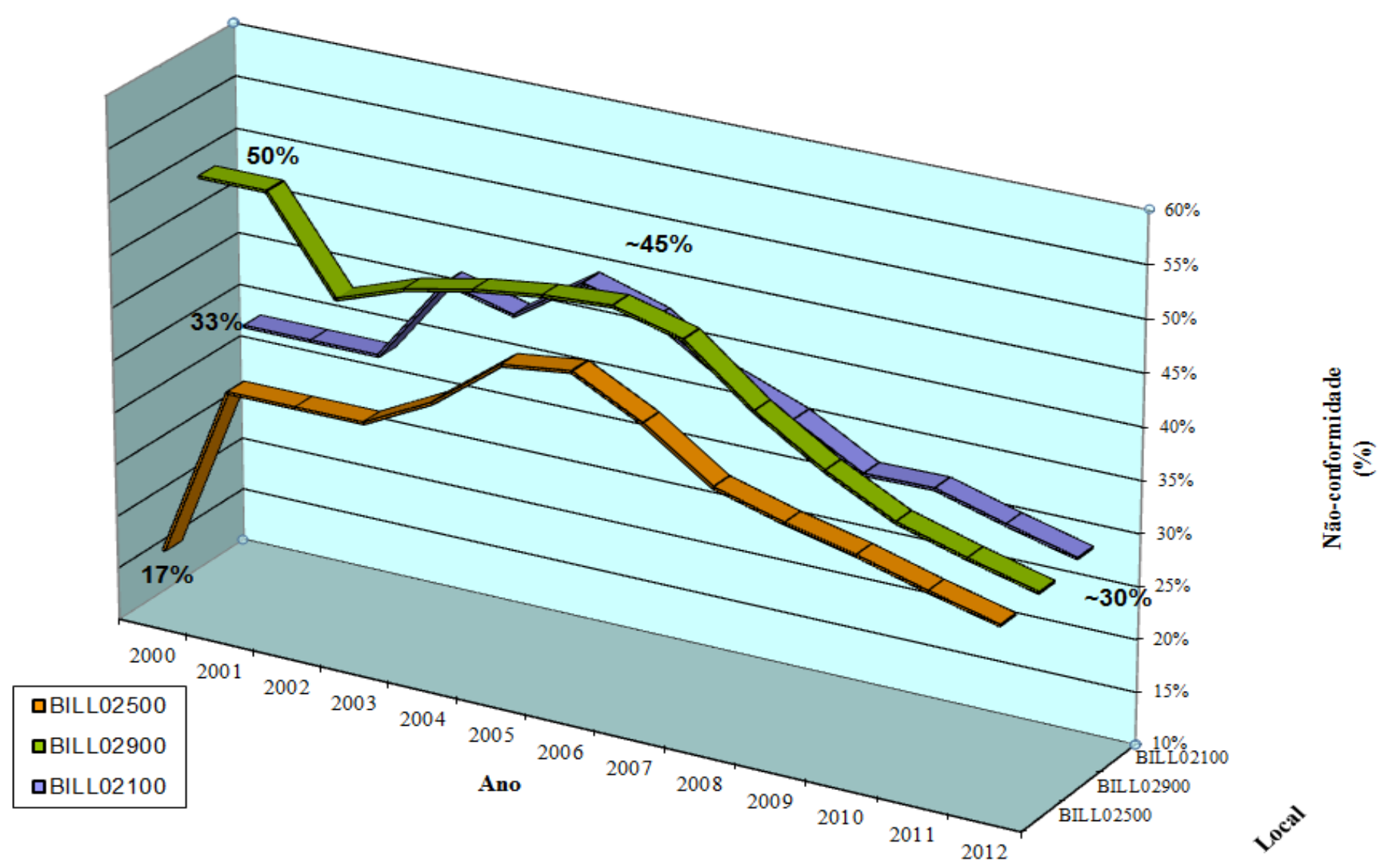

FIGURA 3.1. Gráfico com as porcentagens de não conformidades versus histórico dos resultados, adaptado dos relatórios anuais disponíveis pela CETESB (2000-2012). 
Calculando a pontuação para cada ano e cada ponto de amostragem, pode-se observar que a contaminação tem regredido historicamente. É também possível verificar sua dinâmica, comparando com os outros pontos. Os resultados da pontuação de risco, ano a ano, estão graficamente demonstrados na FIG. 3.2.

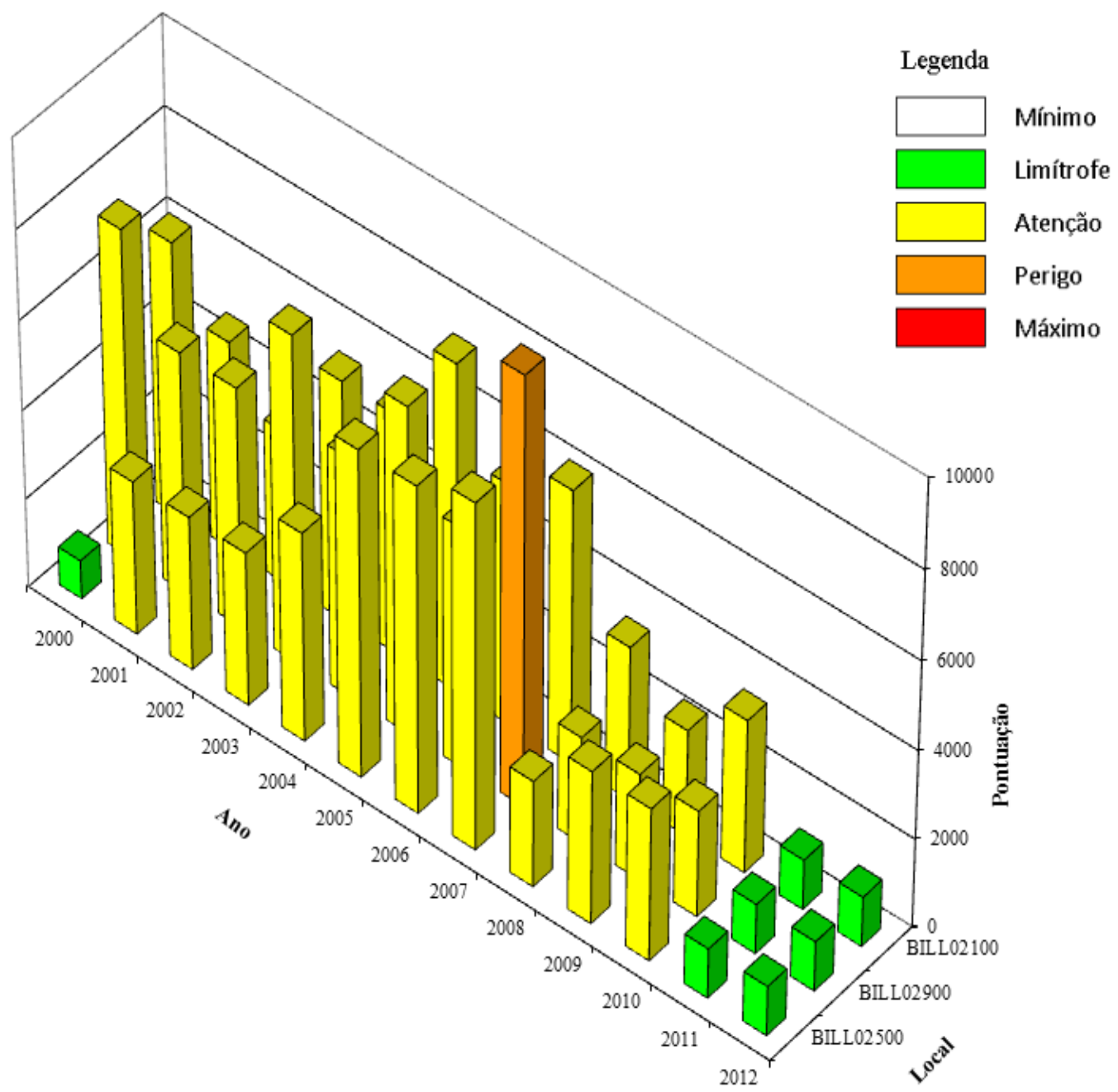

FIGURA 3.2. Gráfico com os resultados históricos da regressão de contaminação por alumínio.

Cerca de $86 \%$ da pontuação de risco foi posicionada em nível de alerta Atenção, com resultados entre 2.400 e 7.776 em todas os pontos nesta situação. O restante, cerca de $14 \%$, foram posicionados no nível de alerta Limítrofe com sete resultados.

Um resultado no ponto BILL02500 - ano 2000 e três resultados analisados no ano 2011 e 2012. O nível de alerta Perigo ocorreu para o ponto BILL002900, com 
pontuação de risco de 9600 no ano de 2007. Nos anos de 2011-12 houve redução significativa do risco potencial de contaminação, por alumínio dissolvido, à saúde humana e do ecossistema aquático, em vista da pontuação de risco igual a 1.125 para os três pontos amostrados. Esses resultados foram atípicos se comparados aos resultados dos anos anteriores.

Nos relatórios não há explicação alguma sobre esses resultados, ou sobre a aplicação de alguma técnica à remoção do metal dissolvido na água da represa Billings.

A média do resultado de alumínio total apresentado durante os anos 2000 a 2012 na água da represa Billings, no ponto BILL0021 foi de 0,32 $\pm 0,22 \mathrm{mg} / \mathrm{l}$, com média muito elevada se comparado aos valores de VMP da antiga portaria do CONAMA 20/86 e desvio padrão igualmente alto; a média do alumínio dissolvido, parâmetro analisado a partir de 2006 até 2012, foi de 0,35 $\pm 0,63 \mathrm{mg} / \mathrm{l}$, o que corresponde a um valor médio que ultrapassa o VMP, de acordo com a portaria 357/05 atualizada pela portaria do CONAMA 430/11 e também desvio padrão quase duas vezes maior que o valor da média apresentada.

Todos os valores caracterizados como $<0,1 \mathrm{mg} / 1$, conforme dados das tabelas e gráficos, foram considerados para todos efeitos de cálculo valores iguais a 0,09 mg/l.

Devido à mudanças da metodologia de avaliação, caracterizada pela filtração por membrana que remove o material particulado de dimensões maiores que $0,45 \mu \mathrm{m}$, cabe salientar que este, pode ser uma combinação de argila, silte, areia e minerais que formam agregados, devido a caracterização do solo da represa Billings.

MARTINS (2007) em seu trabalho observou a formação geológica de uma determinada área e solo da região da represa Billings. O solo é caracterizado por seus horizontes: (1) superficiais com baixa fração de areia e silte e muita argila; (2) intermediários são mais argilosos, menos arenosos e com proporção intermediária de silte; (3) profundos têm tendência ao aumento na percentagem das frações de areia e silte. A argila, o silte e a areia são meios filtrantes, mas as partículas da argila têm uma grande área de superfície por unidade de volume que pode conter mais água e nutrientes (LANDSCAPE, 2013). Conforme Borges (2009), a argila tem em sua composição argilominerais (silicato de alumínio, ferro e outros alcalinos terrosos) e em soluções aquosas propicia a liberação do alumínio.

A argila apresenta uma baixa granulometria natural e é formada por partículas cristalinas de um determinado argilomineral e/ou por uma mistura de diversos argilomineriais. Os argilominerais são compostos por silicatos de alumínio e ferro e certo teor de elementos alcalinos e alcalinos terrosos. Os silicatos de alumínio são apresentados 
em formato de "folhas" unidas e interligadas uma no topo da outra. Essas "folhas" de alumínio têm forma octaédricas, ou seja, duas "folhas" contendo átomos de oxigênio e grupos hidroxila, no qual o $\mathrm{Al}^{3}+, \mathrm{Fe}^{2}+$ ou $\mathrm{Mg}^{2}+$ estão centralizados nas coordenações octaédricas, de maneira que estejam equidistantes de seis átomos de oxigênio ou seis radicais hidroxila. As "folhas" de silício têm forma tetraédrica, ou seja, o átomo de silício está equidistante de quatro átomos de oxigênio ou de quatro grupos hidroxila. Essas "folhas" estão ligadas entre si na forma de "folhas" hexagonais, formando uma "folha" de composição $\mathrm{Si}_{4} \mathrm{O}_{6}(\mathrm{OH})^{4}$. Entre as "folhas" tetraédricas e octaédricas ocorre o compartilhamento dos átomos de oxigênio que estão unidos por ligação covalente. Quando a argila está presente em suspensões aquosas, os íons na sua superfície, entre as "folhas" e no centro do cristal podem ser trocadas por outros íons que estão em solução, o que favorece a liberação do alumínio na água, Dessa forma, ocorre uma troca catiônica e a quantidade total desses cátions trocáveis na argila é conhecida como capacidade de troca catiônica.

Quando há outros compostos orgânicos na água, principalmente os ácidos húmicos, presentes numa concentração de até 30 ppm e responsáveis por $50 \%$ da matéria orgânica nas águas naturais, em contato com a argila, ocorrem uma troca catiônica, expondo o alumínio para o meio (BORGES, 2009). Outro fator de risco desses ácidos húmicos à saúde, relatado por Juhna et al., (2003) é dado no processo de purificação da água para o consumo humano, onde o ácido húmico reage com o cloro (agente desinfectante) formando produtos carcinogênicos, como os tri-halometanos e outros compostos orgânicos halogenados.

O aumento da concentração de matéria orgânica na água da represa, incluindo as substâncias húmicas, está sendo causado pelo lançamento de efluentes industriais, lixo e esgotos domésticos e paralelamente sofre incremento pelo lançamento de águas pluviais, contendo também esgoto, nos afluentes dos rios Tietê e Pinheiros - principais rios poluídos - tornando-se uma represa de contenção de enchentes da cidade, já que não há mais várzeas para favorecer a dinâmica dos rios da cidade em épocas úmidas, pois as mesmas foram ocupadas pela construção e pelo crescimento urbano. Dessa forma, o percurso das águas dos rios é desviado à represa para que as enchentes sejam minimizadas. Com isso, a represa tornou-se um depósito de contaminantes e parte dessa água é destinada ao abastecimento público.

Durante o período de 2001 a 2009 com objetivo de limpar e aumentar o volume de água possibilitando maior geração de energia elétrica na usina Henry Borden, o 
sistema de flotação projetado pelo governo do Estado de São Paulo e instalado próximo à Usina de Pedreira no rio Pinheiros (EMAE \& FCTH, 2009; CESP et al., 2008; FCTH, 2010; OLIVEIRA, 2012), também contribuiu com o acréscimo de sulfato de alumínio, quando nos casos das aberturas das comportas de contenção durante as cheias. Sabe-se que o sulfato de alumínio participa da etapa de coagulação no tratamento de água, mas também possibilita a sua dissolução, o que aumenta o teor de alumínio na água.

Com os resultados obtidos das águas superficiais da represa e com as bases metrológicas mostrando que para obter informação confiáveis, deve ser realizada a repetibilidade de análises e controle do método analítico, implicando em maior frequência de monitoramento e consequentemente, em maior margem de segurança nos resultados (GÜNZLER, 1996; KUSELMAN, 2000), o programa PAMQUÁ ${ }^{\circledR}$ foi adequado para a aplicação neste estudo.

\subsection{Conclusões}

Os resultados obtidos a partir da ferramenta PAMQUÁ ${ }^{\circledR}$ mostraram, através de níveis de alerta, a qualidade da água do reservatório Billings, caracterizado pelo estudo específico da contaminação por alumínio em suas águas superficiais. Essa ferramenta pode ser aplicada no caso de outros metais, permitindo sua investigação histórica de estudo.

De fato a ferramenta contribuiu para reduzir a incerteza de tendências, além de verificar a baixa frequência de monitoramento nos poucos pontos amostrados e contribuiu para a tomada de decisão sobre o estudo do alumínio nesta tese. 


\section{REFERÊNCIAS BIBLIOGRÁFICAS}

AUTOMOTIVE INDUSTRY ACTION GROUP - AIAG. Failure mode and effect analysis. United States: AIAG, 1993.

BAPTISTA, D.F.; BUSS, D.F.; EGLER, M.; GIOVANELlI, A.; SILVEIRA, M.P; NESSIMIAN, J.L. A multimetric index based on benthic macroinvertebrates for evaluantionof Atlantic Forest streams at Rio de Janeiro State, Brazil. Hydrobiologia 575:83-94, 2007.

BORGES, R. S. Remoção de ácido húmico presente na água por adsorção em argila modificada por surfactante catiônico. Tese de Mestrado - Universidade Federal do Rio de Janeiro - UFRJ. 72p. 2009.

CARTER, J.L. \& RESH, V.H. After site selection and before data analysis: sampling, sorting, and laboratory procedures used in stream benthic macroinvertebrate monitoring programs by USA state agencies. Journal of the North American Benthological Society, 20(4):658-682, 2001. Disponível em: < $\underline{\text { http://wwwrcamnl.wr.usgs.gov/tracel/references }}$ /pdf/JNAmBentholSoc_v20n4p658.pdf.>Acesso em 21 ago.2013

COMPANHIA AMBIENTAL DO ESTADO DE SÃO PAULO. Relatório de qualidade das águas interiores do estado de São Paulo. 2000 / CETESB. São Paulo: CETESB, v.1: 214p; v.2: Resultados dos parâmetros e indicadores de qualidade das águas. 138p. Disponível em: $<\underline{\text { http://www.cetesb.sp.gov.br/agua/aguas-superficiais/35-publicacoes-/- }}$ $\underline{\text { relatorios }>}$

COMPANHIA AMBIENTAL DO ESTADO DE SÃO PAULO. Relatório de qualidade das águas interiores do estado de São Paulo. 2001 / CETESB. São Paulo: CETESB, 227p. + ANEXOS 23p. Disponível em: < http://www.cetesb.sp.gov.br/agua/aguassuperficiais/35-publicacoes-/-relatorios $>$

COMPANHIA AMBIENTAL DO ESTADO DE SÃO PAULO. Relatório de qualidade das águas interiores do estado de São Paulo. 2002 / CETESB. São Paulo: CETESB, 279p. Disponível em: <http://www.cetesb.sp.gov.br/agua/aguas-superficiais/35publicacoes-/-relatorios>

COMPANHIA AMBIENTAL DO ESTADO DE SÃO PAULO. Relatório de qualidade das águas interiores do estado de São Paulo. 2003 / CETESB. São Paulo: CETESB, 273p. Disponível em: <http://www.cetesb.sp.gov.br/agua/aguas-superficiais/35publicacoes-/-relatorios>

COMPANHIA AMBIENTAL DO ESTADO DE SÃO PAULO. Relatório de qualidade das águas interiores do estado de São Paulo. 2004 / CETESB. São Paulo: CETESB, 307p. Disponível em: < http://www.cetesb.sp.gov.br/agua/aguas-superficiais/35publicacoes-/-relatorios> 
COMPANHIA AMBIENTAL DO ESTADO DE SÃO PAULO. Relatório de qualidade das águas interiores do estado de São Paulo. 2005 / CETESB. São Paulo: CETESB, 488p. Disponível em: $<$ http://www.cetesb.sp.gov.br/agua/aguas-superficiais/35publicacoes-/-relatorios $>$

COMPANHIA AMBIENTAL DO ESTADO DE SÃO PAULO. Relatório de qualidade das águas interiores do estado de São Paulo. 2006 / CETESB. São Paulo: CETESB, 327p. Disponível em: < http://www.cetesb.sp.gov.br/agua/aguas-superficiais/35publicacoes-/-relatorios $>$

COMPANHIA AMBIENTAL DO ESTADO DE SÃO PAULO. Relatório de qualidade das águas interiores do estado de São Paulo. 2007 / CETESB. São Paulo: CETESB, 528p + anexos. Disponível em: < http://www.cetesb.sp.gov.br/agua/aguas-superficiais/35publicacoes-/-relatorios $>$

COMPANHIA AMBIENTAL DO ESTADO DE SÃO PAULO. Relatório de qualidade das águas interiores do estado de São Paulo. 2008 / CETESB. São Paulo: CETESB, 537p. Disponível em: < http://www.cetesb.sp.gov.br/agua/aguas-superficiais/35publicacoes-/-relatorios $>$

COMPANHIA AMBIENTAL DO ESTADO DE SÃO PAULO. Relatório de qualidade das águas interiores do estado de São Paulo. 2009 [recurso eletrônico] / CETESB. São Paulo: CETESB, $310 \mathrm{p}+$ anexos. Disponível em: < http://www.cetesb.sp.gov.br/agua/aguas-superficiais/35-publicacoes-/-relatorios $>$

COMPANHIA AMBIENTAL DO ESTADO DE SÃO PAULO. Relatório de qualidade das águas subterrâneas do Estado de São Paulo. 2010. CETESB. São Paulo: CETESB, 298p+anexos. Disponível em: $<\mathrm{http}: / /$ www.cetesb.sp.gov.br/agua/agua-superficiais/35publicacoes-/-relatorios $>$

COMPANHIA AMBIENTAL DO ESTADO DE SÃO PAULO. Relatório de qualidade das águas superficiais no estado de São Paulo. 2011. [recurso eletrônico] / CETESB. São Paulo: CETESB, 356p + anexos. Disponível em: $<$ http:// www.cetesb.sp.gov.br/agua/aguasuperficiais/35-publicacoes-/-relatorios $>$

COMPANHIA AMBIENTAL DO ESTADO DE SÃO PAULO. Relatório de qualidade das águas superficiais no estado de São Paulo. 2012. [recurso eletrônico] / CETESB. São Paulo: CETESB, 370p. Disponível em: $<$ http:// www.cetesb.sp.br/agua/aguasuperficiais/35-publicacoes-/-relatorios $>$

COMPANHIA DE SANEAMENTO BÁSICO DO ESTADO DE SÃO PAULO SABESP. Diagnóstico Hidrogeológico da Região Metropolitana de São Paulo, Relatório Final. Convênio SABESP/CEPAS - IGc-USP. São Paulo. SABESP, Glossário geral de O que fazemos \Captação de Água\Represa Billings. São Paulo, SP, 2008. Disponível em: $<$ http://www.sabesp.com.br/CalandraWeb/CalandraRedirect/?temp $=4 \& p r o j=$ sabesp\&pub= $\mathrm{T} \& \mathrm{db}=\& d$ ocid=1A79663C3EE0D06D832571AE006ED94B\#> . Acesso em : 10 mai. 2009. 
COMPANHIA ENERGÉTICA DE SÃO PAULO, EMPRESA METROPOLITANA DE ÁGUAS E ENERGIA E FUNDAÇÃO CENTRO TECNOLÓGICO DE HIDRÁULICA. Avaliação da Qualidade das Aguas do Sistema Pinheiros Billings em Função da Operação do Protótipo da Flotação. Relatório Final, volumes 1 a 4 e anexos, São Paulo: CESP, EMAE e FCTH, Brasil, 2008.

EMPRESA METROPOLITANA DE ÁGUAS E ENERGIA e FUNDAÇÃO CENTRO TECNOLÓGICO DE HIDRÁULICA. Avaliação da Qualidade da Água do Sistema Pinheiros-Billings com o Protótipo do Sistema de Flotação - Estudos Complementares. Relatório Final, volumes 1 a 4 e anexos, São Paulo: EMAE e FCTH, Brasil, 2009.

FAWLER, J. \& COHEN, L. Practical statistics for field biology. WILEY, J. \& CHICHESTER, S. New York. 1990.

FUNDAÇÃO CENTRO TECNOLÓGICO DE HIDRÁULICA. Avaliação do Sistema Pinheiros-Billings com o protótipo de flotação. Relatório Final. São Paulo: FCTH, 2010.

GERRITSEN, J. Additive biological indices for resource management. Journal of the North American Benthological Society 14(3):451-457, 1995.

GÜNZLER, H. Accreditation and quality assurance in analytical chemistry. Springer, Germany, 1996.

JUHNA, T.: KLAVINS, M. EGLITE, L. Sorption of humic substances on aquifer material at artificial recharge of groundwater. Chemosphere, v51, p.861-868, 2003.

KUSELMAN, I. Applications of metrology, chemometrics and quality assurance in analytical chemistry. Metrology, chemometrics and quality assurance 19, 3-4:217-233, 2000 .

LANDSCAPE. Differences between sand, silt and clay. 2013. Disponível em:< http://www.landscapeinfoguide.com.au/articleFiles/201011151323DIFFERENCESBETW EENSAND.pdf $>$. Acesso em: 26 ago.2013.

MARTINS, G. M. Efeitos da ação de cupins sobre propriedades de um perfil de solo em uma vertente da Represa Billings. Dissertação de mestrado. 89p. 2007. Disponível em: $<$ http://www.google.com.br/?gws_rd=cr\#fp=7715f2d73d122941\&q=solo+argiloso+na+rep resa+bilings + pdf $>$ Acesso em: 26 ago.2013

MELO, A. S. \& HEPP, L.U. Ferramentas Estatísticas para Análises de Dados Provenientes de Biomonitoramento. O ecologia brasiliensis. 12 (3): 463-486, 2008.

MESQUITA, K.A.P.C. Modelagem matemática: uma alternativa para o ensino de funções exponenciais e logarítmicas. Departamento de Matemática do Paraná - UFPR, Brasil. 9p. 2013. 
OLIVEIRA, T.; SARKIS, J.E.S.; ULRICH, J.C.; MENEZES, L.C.B.; CASTRO, P.M.G.; MARUYAMA, L.S.; BAZANTE-YAMAGUISHI, R.; MONTEIRO JÚNIOR, A.J. Determinação dos metais $\mathrm{Al}, \mathrm{Cd}, \mathrm{Cr}, \mathrm{Cu}, \mathrm{Hg}, \mathrm{Mg}, \mathrm{Pb}$ e $\mathrm{Zn}$ presentes em tecidos de peixes da represa Billings, São Paulo. In: XI Reunião Científica do Instituto de Pesca. p.194-196. 2012. Disponível em: <http://www.pesca.sp.gov.br/11recip2013/resumos.htm. $>$. Acesso em 26 ago.2013.

PLAFKIN, J.L.; BARBOUR, M.T.; PORTER, K.D.; GROSS, S.K.; HUGHERS, R.M. Rapid bioassessment protocols for use in streams and rivers: benthic macroinvertebrates and fish. EPA/444/4-89/001. Office of Water, US Environmental Protection Angency, Washington, DC. 1989.

SAMPAIO, S.A. Quantificação de metais em águas e sedimentos do reservatório Billings por fluorescência de raios $x$ com reflexão total e radiação Sincroton (SR-TXRF). Dissertação (Mestrado). Faculdade de Engenharia Civil, Arquitetura e Urbanismo. Universidade Estadual de Campinas, São Paulo. 193p. 2007.

UNDERWOOD. Experiments in ecology. Cambridge University Press, 1997.

US ENVIRONMENTAL PROTECTION AGENCY. Sampling ambient water for trace metals at EPA Water Quatity Criteria Levels. US EPA Method 1660, 1996. 


\section{DEGRADAÇÃO RADIOLÍTICA DO ÁCIDO HÚMICO: ESTUDO DA PROPOSTA DE PRÉ-TRATAMENTO DE AMOSTRAS DE ÁGUAS DE MANANCIAIS}

\subsection{Introdução}

As leis que regulam a qualidade dos recursos hídricos no Brasil requerem cada vez resultados analíticos mais precisos em termos de especiação química de metais tóxicos a nível traço para o controle e monitoramento do meio ambiente. Embora vários métodos analíticos sejam conhecidos, esse nível de precisão é atingido quando se conjuga metodologias e/ou técnicas distintas. Em ambientes aquáticos, grande parte da fração contém metais perigosos, material particulado e coloidal de origem distinta, os quais podem ser transportados, permanecendo na coluna d'água ou serem depositados no sedimento, tornando-se biodisponíveis aos organismos aquáticos.

Diversos trabalhos apontam a importância de entender como é a interação entre matéria orgânica natural (MO) em amostras de água (superfícial ou subterrânea). Fernandes et al. (2009) realizaram a determinação de metais traço em águas superficiais e verificaram a interação da MO com metais. Os processos físico-químicos que incluem essa interação da MO com um íon metálico muitas vezes estão associados às reações de quelação ${ }^{1}$, cujo produto é uma substânica complexa que possui propriedades físicoquímicas distintas das do íon metálico e da $\mathrm{MO}$ originais devido à dinâmica natural e complexidade da MO nos sistemas.

Atualmente o controle de qualidade químico analítico está dedicado às técnicas de medição e não ao preparo da matriz de estudo. Dessa forma, a preparação da amostra antes de sua medição é fundamental para a obtenção de resultados confiáveis e de qualidade. Para determinar metais dissolvidos em águas naturais podem ser empregadas técnicas de pré-tratamento amostral e pré-concentração de espécies que estejam em nível traço.

\footnotetext{
${ }^{1}$ Quelação (MORRISON \& BOYD, 1983): processo de formação de um composto químico constituído por um íon metálico e uma ou várias estruturas moleculares. Cada estrutura apresenta uma ou várias ligações covalentes, sendo que uma estrutura ligante dessas pode formar um anel que segura o metal por cada ponto de ligação. Exemplos de estruturas ligantes são compostos orgânicos como aminoácidos, peptídeos ou polissacarídeos.
} 


\subsubsection{Técnicas de pré-tratamento amostral para análise química}

O objetivo principal de realizar o pré-tratamento de qualquer amostra é diminuir os efeitos de interferências causados, principalmente por matriz orgânica, possibilitando a análise do elemento de interesse. Os procedimentos mais comuns para o pré-tratamento à análise de metais são a dissolução e a mineralização. Para isso a seleção de um tratamento apropriado, tanto para a dissolução da amostra como para a mineralização depende de dois fatores: 1) natureza da amostra e 2) matriz do estudo, podendo esta ser predominantemente orgânica ou inorgânica (TWYMAN, 2005).

Segundo TWYMAN (2005) ainda, para a determinação de um metal é importante seguir sete passos para obtenção de resultados quantitativos concisos: (1) amostragem; (2) tratamento da amostra; (3) pesagem; (4) digestão ou mineralização; (5) eliminação de interferentes; (6) definição de réplicas e (7) a escolha do método. De acordo com o tipo da matriz (sólida ou líquida) estes passos poderão ser atribuídos em parte da amostra ou na sua integra. Em geral amostras líquidas não passam por todas essas etapas, entretanto, se a concentração do analito for inferior ao limite de detecção do método escolhido ou apresentar MO complexa será preciso pré-concentrar a amostra e/ou mineralizá-la.

Para a realização da pré-concentração da amostra a matriz poderá passar por processos de separação, como por exemplo, extração líquido-líquido, troca iônica, extração em fase sólida e co-precipitação (POZEBON \& MARTINS, 2002; MACHAT et al., 2002; BURBA \& BERGH, 2004). A co-precipitação é uma técnica que separa substâncias orgânicas ou inorgânicas da matriz, simultaneamente podendo ser classificada como um eficiente adsorvedor seletivo. São métodos empregados com o objetivo principal de tornar a amostra mais homogênea possível e realizar a sua mineralização de forma mais efetiva.

A etapa da pesagem da amostra é também fundamental, pois os possíveis erros analíticos podem ser rastreados por uma simples calibração de balanças ou ainda estar associados à escolha correta da balança, de acordo com a sua precisão e consequentemente, a finalidade do estudo.

A digestão é a etapa em que a amostra precisa chegar a uma solução isenta de qualquer tipo de resíduo orgânico e para isso, a escolha da técnica deverá ser aquela mais simples, rápida, onde se utiliza pequenos volumes de reagentes químicos, permitindo então, a dissolução de um grande número de amostras, produzindo resultados precisos e exatos (ARRUDA et al., 1997). O princípio químico no processo da digestão é o tempo e 
temperatura, podendo ser classificada por duas vias: (1) calcinação ou seca ou (2) úmida ou ácida.

$\mathrm{Na}$ digestão por via úmida, são aplicados aditivos conhecidos classicamente pelo seu poder de oxidação como os ácidos fortes - ácido clorídrico $(\mathrm{HCl})$, nítrico $\left(\mathrm{HNO}_{3}\right)$, ácido sulfúrico $\left(\mathrm{H}_{2} \mathrm{SO}_{4}\right)$, ácido perclórico $\left(\mathrm{HClO}_{4}\right)$ - e ainda peróxidos como o peróxido de hidrogênio $\left(\mathrm{H}_{2} \mathrm{O}_{2}\right.$ - água oxigenada). Esses aditivos associados a altas temperaturas e pressão podem complementar o processo de digestão.

Foi levantado por Wasilewska et al.(2002) que a oxidação de compostos orgânicos por completo em amostras contendo ácido nítrico, gira em torno de $300{ }^{\circ} \mathrm{C}$. Dessa forma, deve-se levar em conta, o tipo de equipamento utilizado para essa quebra (termal clássico ou microondas). Entretanto, a quebra pode se tornar insignificante, quando a amostra atinge sua temperatura de estado estacionário, ou seja, o ácido não tem mais sua eficácia. Sabe-se que o ácido nítrico $\left(\mathrm{HNO}_{3}\right)$ é muito utilizado na dissolução e na decomposição da matriz orgânica, porém somente parte do carbono contido na matéria orgânica pode ser convertida em dióxido de carbono pela ação desse ácido conjugada à temperatura que deve ser de até $200{ }^{\circ} \mathrm{C}$ (temperatura máxima dos frascos de $\mathrm{PTFE}^{2}$ utilizados). Isso implica que aumentando o tempo da digestão e elevando a quantidade de ácido nítrico, o processo de decomposição da matriz orgânica não será totalmente efetivo (MATUSIEWICZ \& STANISZ, 2007).

No estudo realizado por Matusiewicz et al., (1989) apud MATUSIEWICZ \& STANISZ (2007) o peróxido de hidrogênio foi misturado com o ácido nítrico para melhorar a eficácia do processo de digestão da amostra, entretanto a decomposição não foi completa. Bispo et al. (2005) utilizaram o dióxido de manganês como agente oxidante no processo de co-precipitação do metal chumbo em suas amostras de água de rio e quantificaram o metal pela técnica de ICP-OES. Como parte dessa metodologia, eles descrevem que a irradiação por ultrassonografia assistida foi fundamental para separar a matéria orgânica complexa da matriz de estudo.

O peróxido é um oxidante que se converte em água e oxigênio durante o processo de oxidação do material biológico; em pouca quantidade o peróxido consegue reagir devido sua forte reação.

${ }^{2}$ PTFE (MANO, 1994) - polímero perfluorado politetrafluoroetileno, cujo mero é $-\left({ }_{2} \mathrm{FC}_{-} \mathrm{CF}_{2}\right)-$. Tem como características alta resistência química e térmica. 
Em geral as técnicas convencionais de dissolução por via úmida consomem muito tempo e algumas marchas analíticas são potencialmente suscetíveis à contaminação e à perda de elementos químicos por volatilização. O uso de métodos clássicos, como por exemplo, digestão com auxilio de mufla, pode fazer com que alguns elementos químicos sejam perdidos por volatização ou adsorvidos na parede do forno. A digestão por microondas apresenta vantagens, pois reduz o tempo de preparo, bem como os riscos associados aos métodos clássicos. Dessa forma, a escolha do método é o primeiro passo antes da iniciar qualquer análise e deve ser considerado o tipo da amostra, seu custo, o limite de detecção, a calibração e sua validade, a forma de preparo de soluções padrão e a obtenção de curvas analíticas precisas (KINGSTON \& JASSIE, 1988).

Interferências causadas pelos compostos orgânicos complexos que não foram completamente digeridos podem ocorrer principalmente quando se utiliza métodos de espectrometria atômica na quantificação do metal, como por exemplo, a espectrometria por absorção Atômica (AAS), espectrometria óptica por plasma acoplado ICP-OES e a espectrometria por massa atômica de absorção por plasma ICP-MS (KNAPP et al., 1998: MACHAT et al., 2002). Dessa forma, para obter resultados reprodutíveis da matriz em estudo, além do método analítico instrumental, devem-se somar as técnicas de digestão ou decomposição de matrizes orgânicas complexas.

Para a minimização da MO pode-se lançar mão também dos ditos Processos de Oxidação Avançado (POA) que utilizam agentes altamente reativos e que iniciam uma sequência de reações químicas para a destruição e remoção das substâncias orgânicas. São exemplos de POA, além da técnica por microondas: (1) fotólise por UV (WANG et al, 2000), (2) foto-catálise (peróxido de hidrogênio e ozônio), (3) reagente de Fenton e (4) radiólise da água (FERNANDES et al., 2009; BURROWS et al., 2002).

No estudo realizado por Matusiewicz \& Stanisz (2007), empregou-se oxidação de substâncias orgânicas através da integração de dois processos: (1) microondas e (2) ultravioleta com óxido de titânio $\left(\mathrm{UV}-\mathrm{TiO}_{2}\right)$, sendo o $\mathrm{TiO}_{2}$ o principal catalisador ${ }^{3}$. Os resultados apresentados apontaram que houve a digestão completa nas amostras, medida pela alta concentração do carbono biológico e compostos orgânicos.

\footnotetext{
${ }^{3}$ Catalisador (MAHAN, 1985): é toda e qualquer substância que acelera uma reação, diminuindo a energia de ativação e a energia do complexo ativado sem ser consumido durante o processo. Um catalisador normalmente promove um caminho (mecanismo molecular) alternativo para a reação.
} 
Nos últimos anos, o processo de degradação radiolítica dos poluentes ambientais vem sendo utilizado para o tratamento de águas naturais e de resíduos químicos de diferentes origens; recentemente este processo está sendo aplicado para o tratamento de água potável (KURUCZ et al., 1991; GETOFF, 1989; MOHAMED et al., 2009; BAZANTE-YAMAGUISHI et. al., 2012).

\subsubsection{Substâncias húmicas: o estudo do ácido húmico}

A água natural contém substâncias cuja origem, a concentração e as características são distintas. O material particulado tem dimensões em diversas ordens de grandeza. Os vírus atingem cerca de $10^{-6} \mathrm{~mm}$, as partículas coloidais encontram-se entre $10^{-6}$ e $10^{-3} \mathrm{~mm}$, o zooplâncton chega a $10^{-2} \mathrm{~mm}$ e as moléculas de substâncias húmicas $(\mathrm{SH})$, dependendo do grau de polimerização, podem atingir valores entre $3,5 \mathrm{~mm} \mathrm{e} 1 \times 10^{-7}$ mm (AWWA, 1990; CAMPOS et al., 2005).

Substâncias húmicas $(\mathrm{SH})$, também conhecida por Matéria Orgânica Natural (MON) ou popularmente húmus, são responsáveis pela cor e turvação das águas. Apesar de sua formação ter sido muito estudada, tendo vários modelos caracterizados pela técnica de espectroscopia de ressonância magnética nuclear (RMN), definiu-se essas substâncias como sendo compostos bi ou tridimensionais com estrutura química diversa (SILVA FILHO \& SILVA, 2002). Sabe-se que possuem sítios de adsorção compostos por grupos funcionais de ácidos carboxílicos, carbonilas, cadeias alifáticas estáveis, unidas por ponte de hidrogênio, cetona, hidroxilas fenólicas, hidroquinonas e alcoólicas (SNOEYINK \& JENKINS, 1980; VELLOSO et al., 1982; AIKEN, 1985; SCHULTEN \& SCHNITZER, 1997). Sua função no meio ambiente é realizar ligação aniônica e se misturar com outros compostos orgânicos e espécies inorgânicas. De acordo com os grupos funcionais são utilizadas como adsorvente de vários metais pesados presentes, principalmente em ambientes aquáticos e em solos, onde complexam facilmente os metais, contribuindo para o equilíbrio do meio ambiente (JONES \& BRYAN,1998).

Nos modelos recentemente propostos, tem-se observado que a estrutura das $\mathrm{SH}$ contém espaços vazios de diferentes tamanhos, onde outros compostos orgânicos sejam eles hidrofílicos ou hidrofóbicos, podem se ligar: carboidratos e matérias proteináceas, lipídeos, agrotóxicos e outros poluentes, substâncias inorgânicas como argilas e óxidoshidróxido são exemplos mais comuns.

Há três tipos distintos de húmus: humina, ácido fúlvico (AF) e o ácido húmico $(\mathrm{AH})$ 
A humina é a fração mais estável, insolúvel em meio alcalino ou em meio ácido diluído e teoricamente a mais antiga e representativa para efeitos de avaliação da idade do solo (GOUVEIA \& PESSENDA, 1999).

O ácido fúlvico (AF) desempenha várias funções importantes no solo: auxilia-o a manter as suas propriedades físicas e químicas e sua capacidade de complexar íons metálicos; a sua ação quelante permite que íons metálicos essenciais não sejam lixiviados e que íons tóxicos tenham as ações nocivas diminuídas, onde sua interação com os íons metálicos se dá principalmente pelos sítios quelantes derivados do catecol, ácido salicílico e ácido ftálico. No trabalho de SOUZA et al. (2006), foram determinadas as constantes de protonação e as constantes de complexação do AF com posterior comparação a seus monômeros formadores. No estudo de Campos et al. (2005) foi verificada a porcentagem de ácido fúlvico presentes nas frações de SH de diferentes massas molares na água e nesse caso, quanto maior é a sua porcentragem, maior é a sua dificuldade de remoção.

$\mathrm{O}$ ácido húmico $(\mathrm{AH})$ é encontrado em maior fração em águas naturais e em diversos ambientes, precipitado na forma de produto escuro e amorfo em meio ácido. Aiken et al. (1985) relata que cerca de 50 a 70\% de todo carbono dissolvido em águas naturais não poluídas são oriundos de sua presença. Em relação aos processos fotofísicos, fotoquímicos e fotobiológico em águas naturais, os AH são altamente heterogêneos e por isso, são empregados nos estudos de coagulação (CAMPOS et al., 2005). Na natureza, os ácidos húmicos apresentam grande variedade molécular estrutural semelhante e que contêm vários grupos funcionais, incluindo os aminoácidos $\mathrm{e}$ fragmentos de polissacárideos benzênicos (LISHTVAN et al., 1976 apud BLUDENKO et al , 2006). A avaliação das constantes de equilíbrio dos grupos carboxílicos e fenólicos nos ácidos húmicos tem sido importante principalmente porque determinam a acidez necessária para verificar a capacidade de permuta iônica e propriedades de desenvolvimento de cargas nos sistemas aquáticos (FERNANDES et al., 2009). O AH possui estabilidade à ação microbiológica tanto no solo e água devido à sua massa molecular elevada e às diversas classes de subprodutos complexos, tais como os biogênicos de eletrólitos fracos, polianiônicos de diferentes tamanhos moleculares (macromoléculas de ligações olefínicas conjugadas, aromáticas e de estruturas fenólicas - quinona e semi-quinona de um amplo espectro de grupos funcionais (- $\mathrm{CO},-\mathrm{COOH},-\mathrm{OH},-\mathrm{NH}-,-\mathrm{NH} 2,-\mathrm{N})$ ) e os cromóforos que são capazes de absorver a radiação eletromagnética de até $\lambda=1,5 \mu \mathrm{m}$ (BLUDENKO et al., 2006). Estas unidades são capazes de se ligar a prótons e cátions metálicos e afetam 
não só a geoquímica dos sistemas naturais, mas também regulam a capacidade do tamponamento de águas, solos e sedimentos e especiação e transporte do metal.

Recentemente, diversos estudos sobre a presença de MON excessiva em águas destinadas ao abastecimento público tem recebido atenção especial dos órgãos fiscalizadores e de grupos de pesquisadores e organização não governamental (MELNICK, 1989; TOLEDANO et al., 2005; EWG, 2013; HUBER, 2010). Excesso de nutrientes como fósforo, nitrogênio amoniacal e microorganismos patogênicos na água (vírus, bactérias, fungos e cianofíceas), tem causado o efeito da eutrofização ${ }^{4}$ e da hipereutrofização ${ }^{5}$, além da disseminação de doenças de veiculação hídrica. A falta de conhecimento e um planejamento adequado à desinfecção de águas contaminadas, através da adição de cloro diretamente em poços semi-artesianos ou em represamentos com elevada concentração de MON conduz à formação de tri-halometanos como subproduto da sua reação com o cloro, sendo esta reação catalisada pela radiação solar. O resultado é a ingestão de água rica nesses subprodutos orgânicos tóxicos, mutagênicos e cancerígenos pela população como consumidores finais (McNEAL et al., 1995; MORRIS et al., 1992; RITTMANN, 1997; MACEDO et al., 2001).

De acordo com Burba \& Bergh (2004) para a especiação de metais tóxicos encontrados nas águas superficiais e subterrâneas ricas em matéria orgânica são necessárias técnicas de remoção capazes de capturar metais em sua forma iônica. Exemplos dessas técnicas são a quelação e a adsorção por coloides húmicos, esses últimos estão disponíveis na biota aquática e possuem mecanismos de ligação com metais. Os coloides e suas espécies metálicas são geralmente constituintes de um sistema dinâmico natural da água e, que estão frequentemente sujeitas a alterações físico-químicas, devido aos processos de precipitação complexa de sorção e coagulação.

Sabendo-se que matéria orgânica pode estar presente em água de mananciais e formar compostos orgânicos complexos com metais, esse capítulo descreve o método e as etapas, incluindo a digestão para $\mathrm{MO}$, a partir de amostras de água que foram simuladas no laboratório, contendo distintas concentrações de ácido húmico.

\footnotetext{
${ }^{4}$ Eutrofização (TUNDISI \& MATSUMURA-TUNDISI, 1995): fenômeno causado pelo excesso de nutrientes (compostos químicos ricos em fósforo ou nitrogênio) numa massa de água, provocando um aumento excessivo de algas.

5 Hipereutrofização: enriquecimento máximo de nutrientes; número excessivo de algas e plantas aquáticas (ao ponto de impedir ou dificultar a navegação).
} 


\subsection{Materiais e Métodos}

\subsubsection{Mineralização}

O método de mineralização aplicado foi um tipo processo de oxidação avançada - o processo de irradiação em alta energia (radiação ionizante) - que foi inovador. No entanto, teve como embasamento a norma EPA 600/R-05/055. Distintos parâmetros foram aplicados na investigação da degradação do ácido húmico em solução aquosa. A presença de aditivos oxidantes e íons alumínio foram os principais parâmetros químicos experimentais, além dos parâmetros físicos (dose e taxa de dose).

\subsubsection{Preparo da solução de ácido húmico}

Soluções de ácido húmico (P.A), da marca Sigma Aldrich (10\% de cinzas secas) como sal de sódio, foram preparadas para simular a matéria orgânica em águas naturais. Foi utilizada água destilada purificada (destilador marca Marconi, modelo MA078) e realizada medição do pH igual a 6,8 utilizando pH-metro de bancada modelo mPA210 da marca Tecnopon, no laboratório de química do Centro de Tecnologia das radiações (CTR). As concentrações dos ácidos húmicos para esse teste foram 5, 10, 50, 100, 250, 500 e 1.000 ppm (ou mg/l). Estas soluções foram também testadas com $1 \%$ (v/v) dos seguintes aditivos grau P.A: ácido nítrico (65\% marca MERCK), ácido sulfúrico ( $97 \%$ ) e peróxido de hidrogênio (30 volumes).

Soluções de ácido húmico (PA) nas concentrações de 1 ppm e 5 ppm misturadas com íons alumínio (cloreto de alumínio - Sigma Aldrich - solução $1.000 \mathrm{mg} / \mathrm{l}$ - pureza espectroscópica AAS) nas concentrações de 0,1 ppm, 0,5 ppm, 2,5 ppm e 5 ppm também foram submetidas ao processo de mineralização.

As soluções foram transferidas para frascos de vidro com capacidade de 5 a 50 ml (FIG. 4.1) e para refratários do tipo Pyrex ${ }^{\circledR}$ retangular (FIG. 4.2), num volume correspondente a $100 \mathrm{ml}$ para a etapa de degradação (digestão) radiolítica das amostras, conforme o tipo de fonte de radiação usada. 


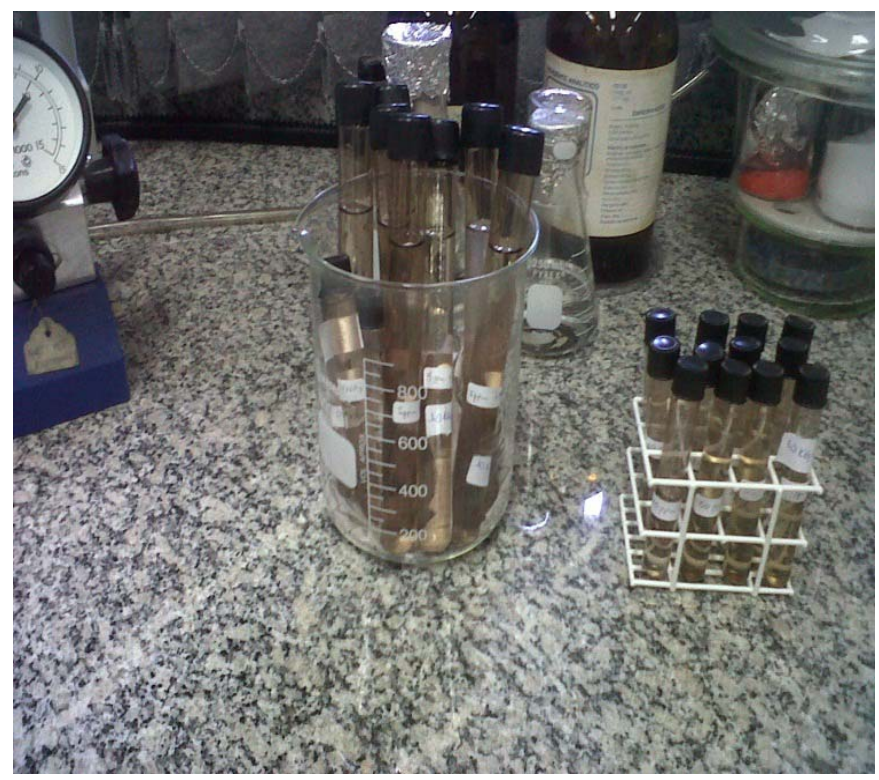

FIGURA 4.1. Preparo de amostras em frascos para o processo por irradiação gama.

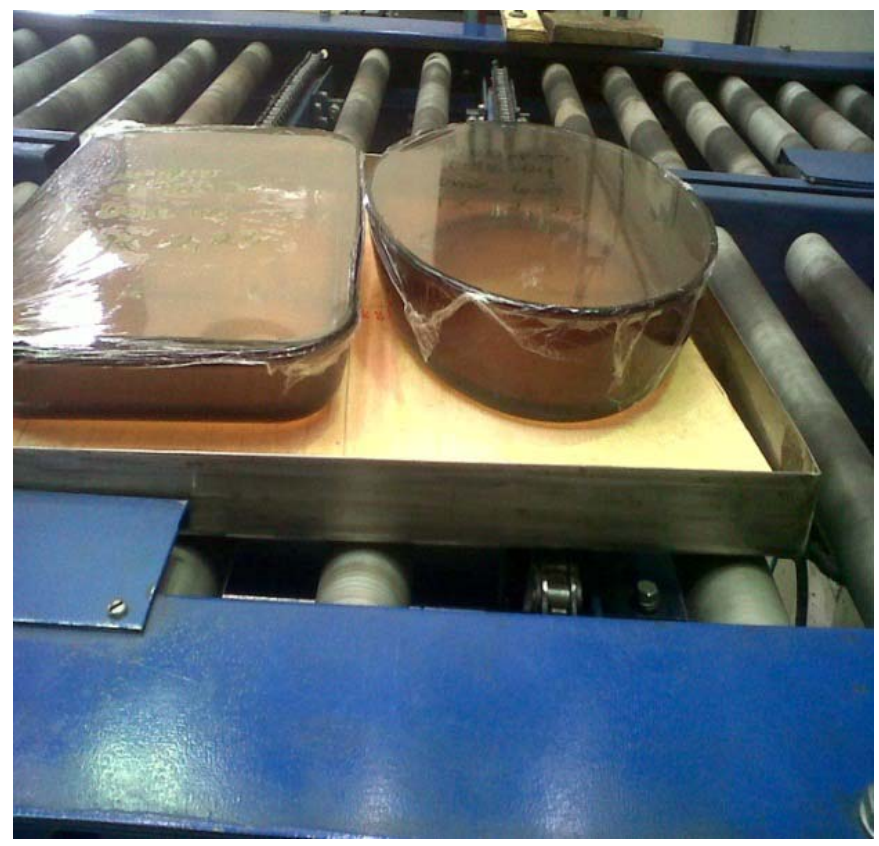

FIGURA 4.2. Preparo de amostras em refratários para o processo de irradiação por feixe de elétrons. 


\subsubsection{Fontes de irradiação}

As amostras foram submetidas a dois tipos de fontes de radiação para que se efetuasse o processo de digestão do ácido húmico: (1) radiação gama fornecida por uma fonte de cobalto $\left({ }^{60} \mathrm{Co}\right.$ - gammacell-220) (FIG. 4.3) e (2) feixe de elétrons produzido por um acelerador de elétrons (Dynamitron $\left.{ }^{\circledR}\right)$, cujo princípio de funcionamento é parecido com o do tubo de raios catódicos.

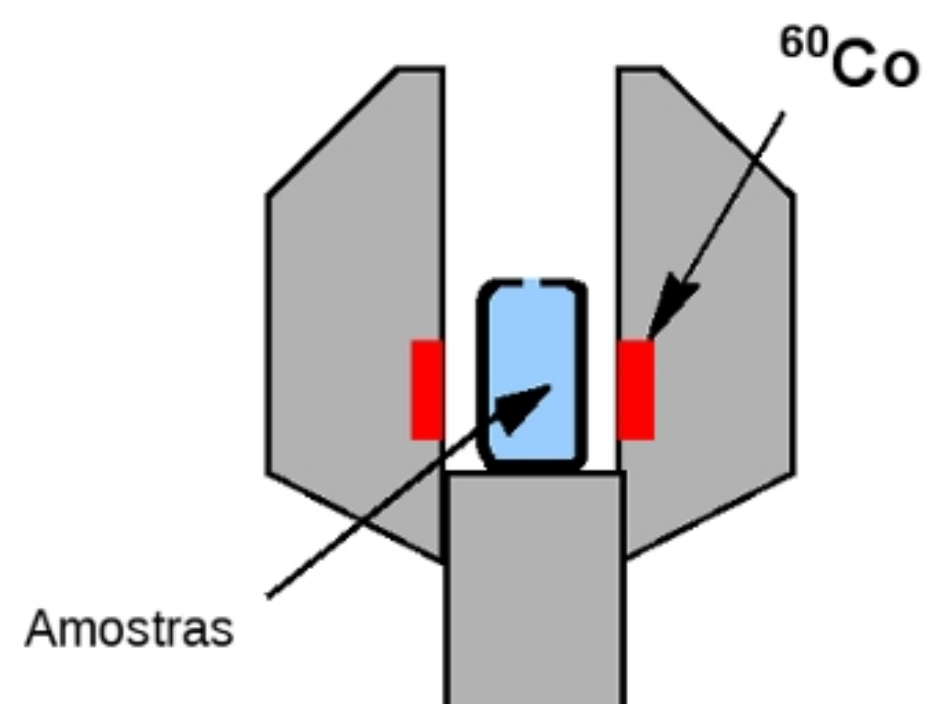

FIGURA 4.3. Desenho esquemático (corte longitudinal) da disposição das amostras no dispositivo de irradiação Gammacell-220.

Para se entender as quantidades de radiação usada neste trabalho, precisa-se ter em mente o conceito de dose absorvida e taxa de dose. Quando materiais diferentes, em termo de natureza molecular, são expostos à radiação ionizante, estes poderão receber diferentes quantidades de energia. Isso acontece porque muitos fenômenos ocorrem, incluindo alterações nas propriedades físicas do material e/ou reações químicas induzidas de acordo com a energia que a unidade de massa do material absorveu. Essa energia absorvida é dada por unidade de massa do absorvedor. Historicamente a dose absorvida era dada pela unidade rad - definida por 100 ergs/gram, no CGS - porém essa unidade tem sido gradualmente susbstitutida por aquela do Sistema Internacional (SI): o gray (Gy), que é definido como 1 Joule/quilograma de material absorvedor (KNOLL, 1989). As duas 
unidades têm a seguinte correspondência: $1 \mathrm{~Gy}=100 \mathrm{rad}$. Taxa de dose então é a quantidade de dose absorvida em um determinado período de tempo (TABATA et al., 1991).

A taxa de dose aplicada no processo de irradiação por raios gama neste trabalho foi de 1,53 Gy/h (dose de trânsito estimada estimada em 1,33 Gy). A irradiação foi realizada à temperatura ambiente $\left(25^{\circ} \mathrm{C}\right)$, seguindo o protocolo ASTM E1026/97. Os tubos de vidro de $50 \mathrm{ml}$ ficaram em disposição simétrica à fonte de radiação de modo a receber a dose o mais uniformemente possível, uma vez que no dispositivo gammacell-220 as amostras ficam circundadas por barras radioativas de ${ }^{60} \mathrm{Co}$, como mostra a FIG. 4.3.

No método de irradiação por feixe de elétrons, as doses aplicadas foram: 5, 10, 20, 40 e $60 \mathrm{kGy}$ e taxas de doses de 2,23 kGy/s e 22,41 kGy/s, respectivamente. A TAB. 1 , apresenta todas as condições das amostras, de acordo com as doses e taxas de estudo.

As amostras foram dispostas em bandejas refratárias do tipo Pyrex ${ }^{\circledR}$ retangular para garantir uma geometria constante e a altura máxima da coluna de amostra foi de $4 \mathrm{~mm}$ para permitir o alcance do feixe de elétrons em todo o corpo da amostra - da superfície ao fundo - e garantir a efetividade da dose.

Cada bandeja contendo as soluções de AH fez um percurso a partir de um ponto inicial (despacho da amostra), como mostra a FIG. 4.4, até atingir a janela do feixe para receber a dose previamente calculada segundo a taxa de dose requerida, a densidade e a espessura da amostra $(4 \mathrm{~mm})$. Naturalmente, para uma dada taxa de dose, o material realiza um percurso tanto maior quanto maior for a dose a ser absorvida. A corrente do feixe é um indicativo do número de elétrons que está sendo acelerado, por exemplo, se a corrente do feixe é de $1 \mathrm{~mA}$, isto representa cerca de 1 milhão de bilhões de elétrons $(1 \mathrm{x}$ $10^{15}$ elétrons) que estão sendo acelerados em um segundo. Sendo assim, a enorme quantidade de elétrons e a alta tensão de aceleração produzem reações rápidas operacionalizadas diretamente nas moléculas contidas no material alvo, com isso a eficiência da técnica é excepcional quando comparada a outros métodos reacionais que utilizam calor, luz e reagentes químicos.

Toda a dosimetria do processo foi realizada através do mapeamento de dose na amostra com o uso de dosímetros do tipo CTA (triacetato de celulose). Dessa forma se determina a dose mínima e máxima recebida pela amostra. 
TABELA 4.1. Condições das amostras e do processo de irradiação por feixes de elétrons

\begin{tabular}{|c|c|c|c|c|c|}
\hline Características & \multicolumn{5}{|c|}{ Resultado } \\
\hline Material & \multicolumn{5}{|c|}{ Ácido húmico + água destilada } \\
\hline Doses (kGy) & 5 & 10 & 20 & 40 & 60 \\
\hline $\begin{array}{l}\text { No. de passadas pelo Feixe de Elétrons (vezes) - taxa } \\
2,23 \mathrm{kGy} / \mathrm{s}\end{array}$ & 10 & 20 & 40 & 80 & 120 \\
\hline No. de voltas pelo equipamento & 5 & 10 & 20 & 40 & 60 \\
\hline $\begin{array}{l}\text { No. de passadas pelo Feixe de Elétrons (vezes) - taxa } \\
22,41 \mathrm{kGy} / \mathrm{s}\end{array}$ & 1 & 2 & 4 & 8 & 12 \\
\hline Voltas pelo equipamento & 1 & 1 & 2 & 4 & 6 \\
\hline Velocidade da bandeja (m/min) & \multicolumn{5}{|c|}{6,72} \\
\hline Energia aplicada (MeV) & \multicolumn{5}{|c|}{1,40} \\
\hline Largura do feixe $(\mathrm{cm})$ & \multicolumn{5}{|c|}{112,0} \\
\hline Corrente do feixe (mA) & \multicolumn{5}{|c|}{0,60} \\
\hline Densidade da amostra $\left(\mathrm{g} / \mathrm{cm}^{3}\right)$ & \multicolumn{5}{|c|}{1,00} \\
\hline Espessura da amostra (mm) & \multicolumn{5}{|c|}{4,00} \\
\hline Dose por passada em taxas 2,23 e 22,41 kGy/s (kGy) & \multicolumn{5}{|c|}{0,5 e 5,0} \\
\hline
\end{tabular}

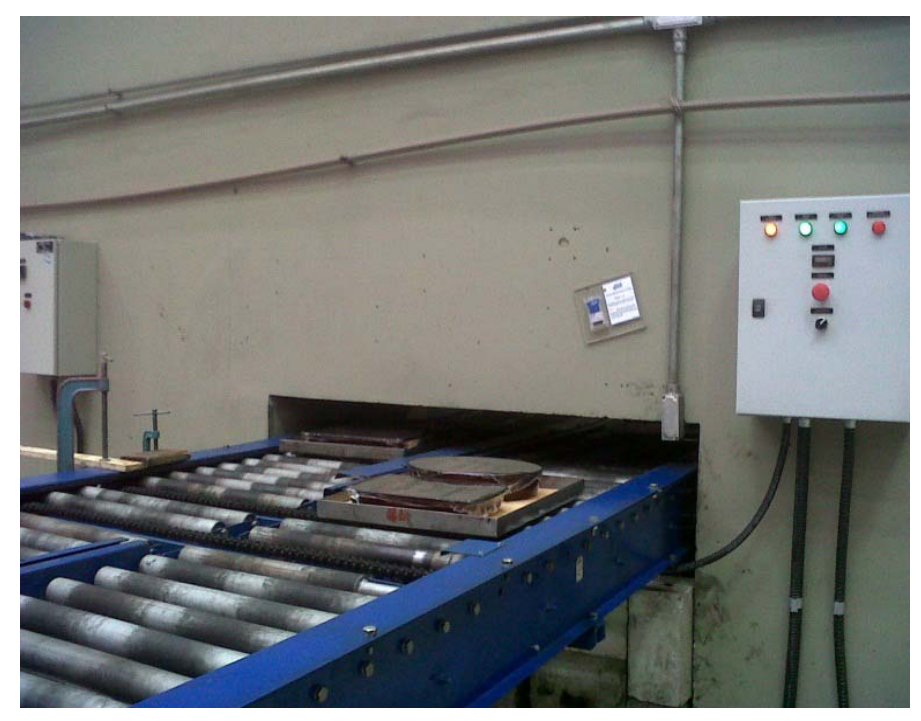

FIGURA 4.4. Amostras sob o processo de irradiação no acelerador de elétrons Dynamitron ${ }^{\circledR}$. 


\subsubsection{Análise instrumental}

A análise instrumental foi realizada a partir das seguintes técnicas: a) espectrofotometria de absorção na região da radiação ultravioleta-visível (UV-vis); b) análise do teor de Carbono Orgânico Total (COT) e espectrofotometria por emissão óptica por plasma indutivo acoplado (ICP-OES).

\subsubsection{Determinação da concentração do AH e análise espectral na região UV-vis}

Foi utilizado o espectrofotômetro UV-Vis, da marca Thermo Scientific, modelo Genesys 10s. Como amostra em branco para a calibração foi utilizada água destilada. A curva de calibração foi conseguida a partir da leitura direta do valor de absorbância em função da concentração das soluções aquosas de ácido húmico padrão nos valores de 0 a 100 ppm no comprimento de onda de $225 \mathrm{~nm}$. A concentração relativa (CR) das soluções de AH irradiadas foi determinada a partir da leitura do valor de absorbância no mesmo comprimento de onda e com esse valor foi calculado o valor da concentração de AH remanescente após o processo ( $\mathrm{a}_{\text {irradiado }}$ ) e relacionado ao valor da concentração original da solução ( $\mathrm{a}_{\mathrm{o}}$ - antes da irradiação) como mostra a relação (2):

$$
C R=\frac{a_{\text {irradiado }}}{a_{o}}
$$

Os espectros das soluções de $\mathrm{AH}$ nas concentrações de 0 a 1.000 ppm não irradiadas e irradiadas foram obtidos na faixa de comprimento de onda de $190 \mathrm{~nm}$ a 600 $\mathrm{nm}$, utilizando o mesmo instrumento analítico e amostra em branco.

\subsubsection{Determinação do carbono orgânico total (COT)}

A leitura direta do COT foi realizada a partir de um analisador TOC da marca Shimadzu modelo 5000A. As amostras injetadas passavam por um sistema de oxidação e o resultado deste processo era detectado por um dispositivo de infravermelho. Resultados de carbono total (CT), carbono inorgânico (CI) e COT eram obtidos simultaneamente após a comparação automática do resultado com uma curva de calibração cujo padrão foi soluções de biftalato de potássio em distintos valores de concentração.

\subsubsection{Determinação dos íons alumínio}




\subsection{Determinação dos íons alumínio por espectrofotometria UV-vis}

A análise quantitativa foi realizada em um espectrofotômetro de UV-Vis, da marca Thermo Scientific, modelo Genesys 10S, acoplado a uma bomba peristáltica, tipo multi-rolo. Este modelo contempla um fluxo de leitura na célula de 1,6 $\mathrm{ml}(1,0 \mathrm{~mm}$ de percurso). O procedimento para a análise quantitativa foi baseado no método do reagente químico cianina de eriocromo R (VOGEL, 1989).

Para isso foram preparadas soluções aquosas do padrão de alumínio (marca Sigma Aldrich) em diversas concentrações (entre $0,1 \mathrm{ppm}$ e $5 \mathrm{ppm}$ ) e de sulfato de potássio e alumínio (P.A.) com concentração de 60 ppm. Utilizou-se também solução de cianina de eriocromo $\mathrm{R}$ na concentração de $1 \%$, solução de peróxido de hidrogênio 5 volumes e solução tampão acetato de sódio/acetato de amônio/ácido acético 0,1 M pH 6.

Para quantificar o alumínio foi transferida uma alíquota de $1 \mathrm{ml}$ da amostra com pipeta volumétrica para um balão volumétrico de $10 \mathrm{ml}$, em seguida foi adicionado 0,5 $\mathrm{ml}$ de peróxido de hidrogênio $\left(\mathrm{H}_{2} \mathrm{O}_{2}\right) 5$ volumes e agitou-se. Com uma pipeta volumétrica foi adicionado $0,5 \mathrm{ml}$ da solução de cianina de ericromo $\mathrm{R}$ e homogeneizou-se a solução. Foi adicionado $5 \mathrm{ml}$ da solução tampão com uma pipeta volumétrica e aferiu-se o volume para $10 \mathrm{ml}$ com água destilada. Com a solução pronta e em repouso de 10 minutos foi possível medir a absorbância no comprimento de onda de $535 \mathrm{~nm}$ contra o branco (célula de $1 \mathrm{~mm}$ de caminho óptico).

Duas curvas de calibração foram construídas a partir de soluções de alumínio obtidas a partir da solução mãe (cloreto de alumínio - Sigma Aldrich - solução $1.000 \mathrm{mg} / 1$ - pureza espectroscópica AAS) diluídas sob rigor analítico: a) com concentrações de 0 a 1 ppm (pontos a cada 0,2 ppm) e b) com concentrações de 0 a 10 ppm (pontos a cada 2 ppm).

\subsection{Determinação dos íons alumínio por ICP-OES (espectrofotometria por emissão óptica por plasma indutivo acoplado)}

A determinação dos íons alumínio foi realizada por ICP-OES de marca Thermo Scientific, modelo Icap 6300 Duo, onde foi utilizada a metodologia USEPA (United States Environmental Protection Agency) 6010C - SMWW846 (Standard Methods for Examination of the Water and Waste Water), padrões NIST 1643e e procedimento operacional padrão DAM060 da empresa ASL (Laboratório São Lucas Análises 
Ambientais Ltda - Rio Claro - Certificado pela empresa Analítica e acreditado pelo INMETRO CRL 0267). Os padrões utilizados foram: $\mathrm{Al}, \mathrm{Ca}, \mathrm{Ba}, \mathrm{Cu}, \mathrm{Mg}, \mathrm{Mn}, \mathrm{Ni}, \mathrm{K}, \mathrm{Zn}$.

Os parâmetros operacionais, como comprimento de onda é 308,2 para Al, o gás auxiliar é o nitrogênio e o gás principal é o argônio. O número de réplicas são três para análise do Al. Os demais parâmetros, tais como composição da chama e calibração plasma, fluxo de gás, fluxo do gás auxiliar, tempo de equilíbrio da fonte, velocidade da bomba, tipo de detector, potência de radiofrequência, fluxo de nebulização, taxa de aspiração da amostra, método de leitura, correção do background, delay de leitura e delay de lavagem não foram autorizados pelo departamento de Garantia de Qualidade da ASL.

\subsection{Resultados e Discussão}

A análise quantitativa espectrofotométrica no UV-vis tem como base a lei de Lambert-Beer (3) que relaciona a intensidade de energia de radiação UV em um dado comprimento de onda e a concentração do analito (VOGEL,1989) :

$$
\log \frac{I_{0}}{I}=\varepsilon c l
$$

Onde: $I_{0}$ e $I$ são respectivamente a intensidades de radiação incidente e de radiação transmitida em um determinado comprimento de onda, $\varepsilon$ é uma constante chamada absortividade molar, $c$ é a concentração do analito (unidade no SI mol/litro) e $l$ é o caminho óptico da célula que comporta o analito.

Foi baseado nesse princípio que a curva de calibração da FIG. 4.5a para cada tipo de solução de AH não irradiada foi construída e com cada equação das retas obtidas foi possível calcular as concentrações relativas das soluções de AH irradiadas em cada caso (sem aditivo e com aditivo), como mostra a FIG. 4.5b.

\subsubsection{Degradação do AH por radiação gama}

O efeito geral da aplicação da radiação gama, como mostra a FIG. 4.5b, é a diminuição da concentração de ácido húmico quando nenhum aditivo é usado. Quando 1 \% de ácido sulfúrico é usado como aditivo reacional é observado um decréscimo na concentração em termos de $46 \%$ da concentração inicial em 5 kGy, porém em 10 kGy ocorre o inverso: um aumento de aproximadamente $63 \%$ da concentração inicial. Este comportamento pode ser relacionado aos distintos mecanismos químicos da degradação do AH quando aditivos são usados. Seriesi et al. (1977) estudaram soluções de ácido húmico em distintos valores de $\mathrm{pH}$ e observaram como resultado altos níveis de agregação das 
partículas do soluto quando a irradiação é realizada nas amostras neutras e ácidas, porém eles sugerem que essas condições de pH não são suficientes para provocar a degradação das substâncias húmicas. Essas observações podem explicar o aumento da concentração relativa do ácido húmico quando se utiliza o ácido sulfúrico.

Ainda na FIG. 4.5b, um comportamento geral é observado em todas as amostras: o processo de irradiação aplicado nas amostras com $50 \mathrm{ppm}$ de $\mathrm{AH}$ tem maior degradação do que aquelas com 100 ppm e neste caso observa-se uma dependência óbvia da concentração em função da cinética de degradação.

Os efeitos da irradiação gama sobre o teor de carbono orgânico total (COT) das soluções de ácido húmico estão mostrados na FIG. 4.6a. Esse resultado mostra desvios pouco significativos quando a irradiação ocorre nos tubos com distintos volumes quando se compara ao valor de COT do material não irradiado nas distintas concentrações estudadas; isto está de acordo com este tipo de processo de irradiação, uma vez que a radiação gama tem alto poder de penetração e nesse caso o desempenho do processo não tem qualquer dependência ou restrição à quantidade de material ou à geometria do material.

A FIG. 4.6b mostra os efeitos da radiação gama nos níveis de COT das amostras irradiadas de solução de AH na concentração de 50 ppm com e sem aditivos. Neste caso foi observado o decréscimo dos valores de COT com o aumento da dose absorvida quando as soluções de $\mathrm{AH}$ são usadas sem aditivo e com $1 \% \mathrm{de}_{2} \mathrm{O}_{2}$, sendo que neste último, o parâmetro analisado diminui cerca de quatro vezes da concentração inicial em $10 \mathrm{kGy}$. No entanto, quando $1 \%$ de $\mathrm{H}_{2} \mathrm{SO}_{4}$ é utilizado como aditivo reacional, há um aumento no teor de COT principalmente em baixo valor de dose absorvida.

A FIG. 4.7 mostra a relação dos níveis de COT das soluções de AH aditivadas e irradiadas com os resultados de COT das amostras não irradiadas. Os resultados mostrados nesta figura confirmam que as soluções com baixa concentração de $\mathrm{AH}$ aditivadas com $\mathrm{H}_{2} \mathrm{SO}_{4}$ e irradiadas em baixas doses possuem altos níveis de COT.

Este comportamento pode ser relacionado àquele observado por Bludenko et al. (2006), onde sugerem a formação de ácido carboxílico de baixa massa molecular por um mecanismo de recombinação molecular quando soluções de MO são irradiadas. Na hipótese deste mesmo comportamento ocorrer no caso das soluções de AH aditivadas com $\mathrm{H}_{2} \mathrm{SO}_{4}$ e irradiadas, o produto resultante pode ser responsável pelo aumento do teor de COT. Ainda na FIG. 4.7, o decréscimo dos níveis de COT das soluções de $\mathrm{AH}$ com $\mathrm{H}_{2} \mathrm{O}_{2}$ comparada às amostras não irradiadas é confirmada em toda faixa de concentração de $\mathrm{AH}$ estudada e os menores valores são observados nas maiores doses absorvidas (10 kGy). 
O carbono inorgânico (CI) foi também determinado e esses resultados estão na FIG. 4.8. Pode-se observar que as amostras irradiadas $\operatorname{com} \mathrm{H}_{2} \mathrm{O}_{2}$ apresentam altos níveis de CI quando comparadas às amostras não irradiadas. Aqui o mecanismo de degradação é relacionado aos efeitos da radiólise do $\mathrm{H}_{2} \mathrm{O}_{2}$; este tipo de aditivo parece ser mais efetivo sobre a degradação do ácido húmico. A agressividade dos radicais óxido/peróxido permite a destruição dos anéis aromáticos que estão presentes na composição do ácido húmico. $\mathrm{O}$ radical hidroxila induz a mineralização das soluções de $\mathrm{AH}$ como verificado por Goldstone et al. (2002). Nesse estudo, esses autores avaliaram o efeito da irradiação gama sobre as soluções de ácido húmico e sugerem que os compostos resultantes da mineralização ocorram sob alta concentração de radical hidroxila. 
a)

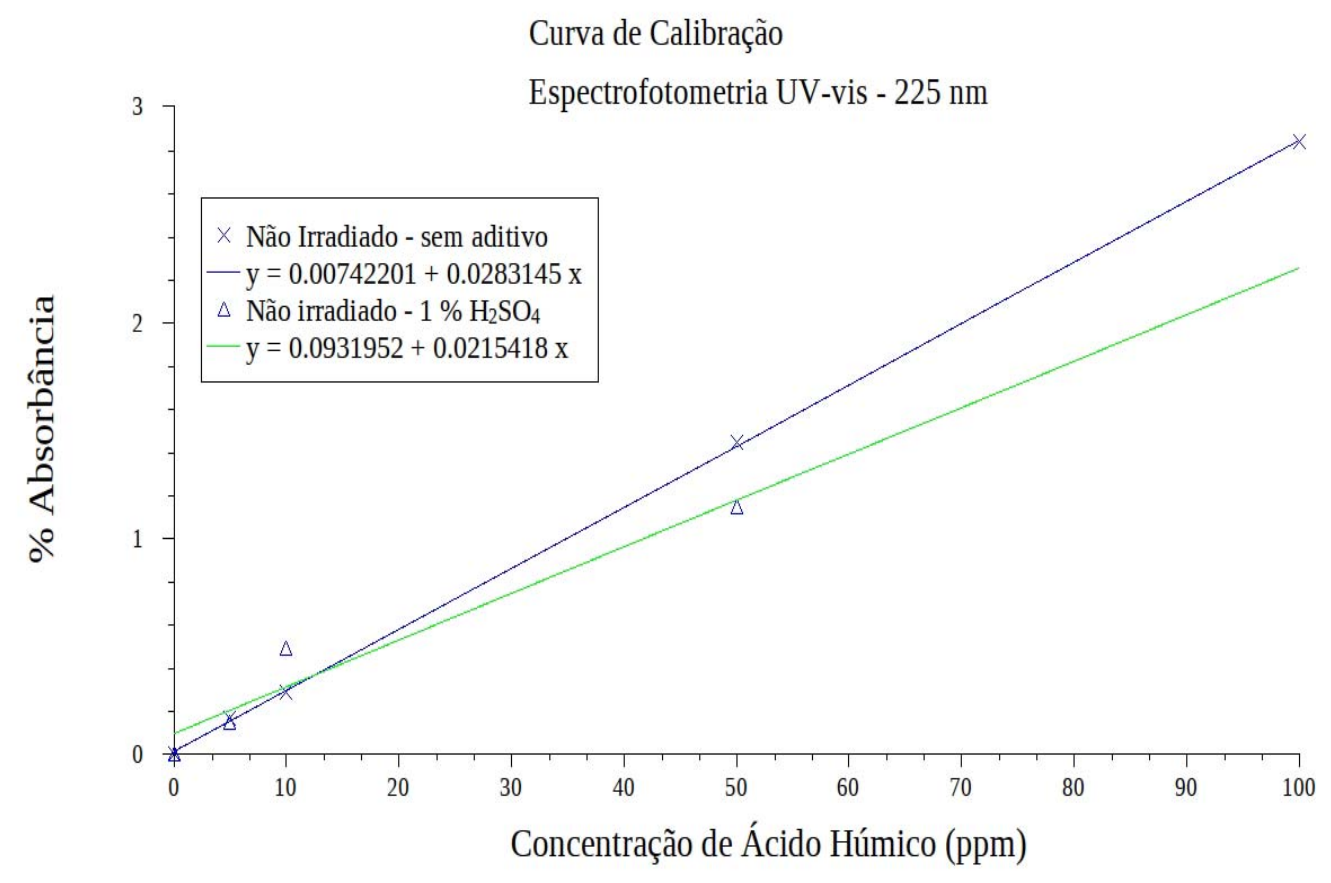

b)

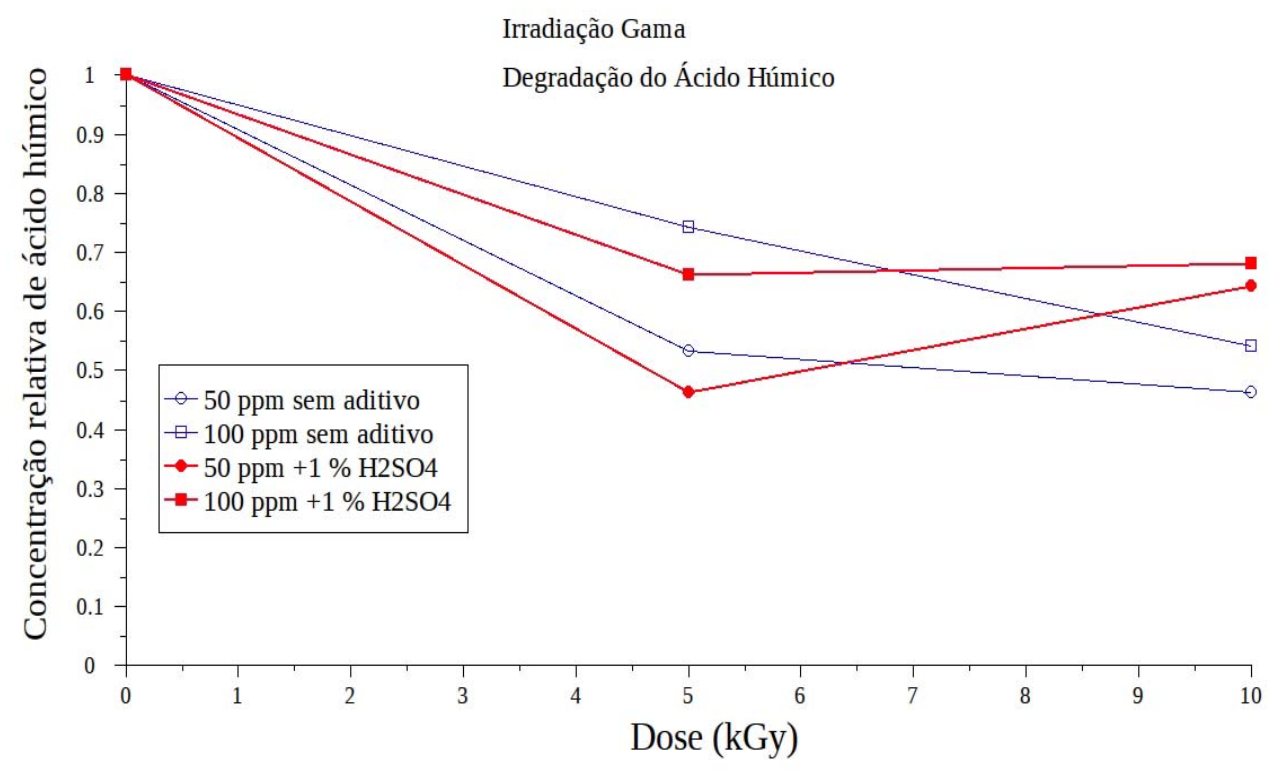

FIGURA 4.5. a) Curva de calibração da espectrofotometria UV-vis das amostras não irradiadas e b) Concentração relativa de ácido húmico calculada a partir da calibração em a) em função da dose de radiação gama. 
a)

Efeitos da irradiação Gamma sobre amostra de ácido húmico

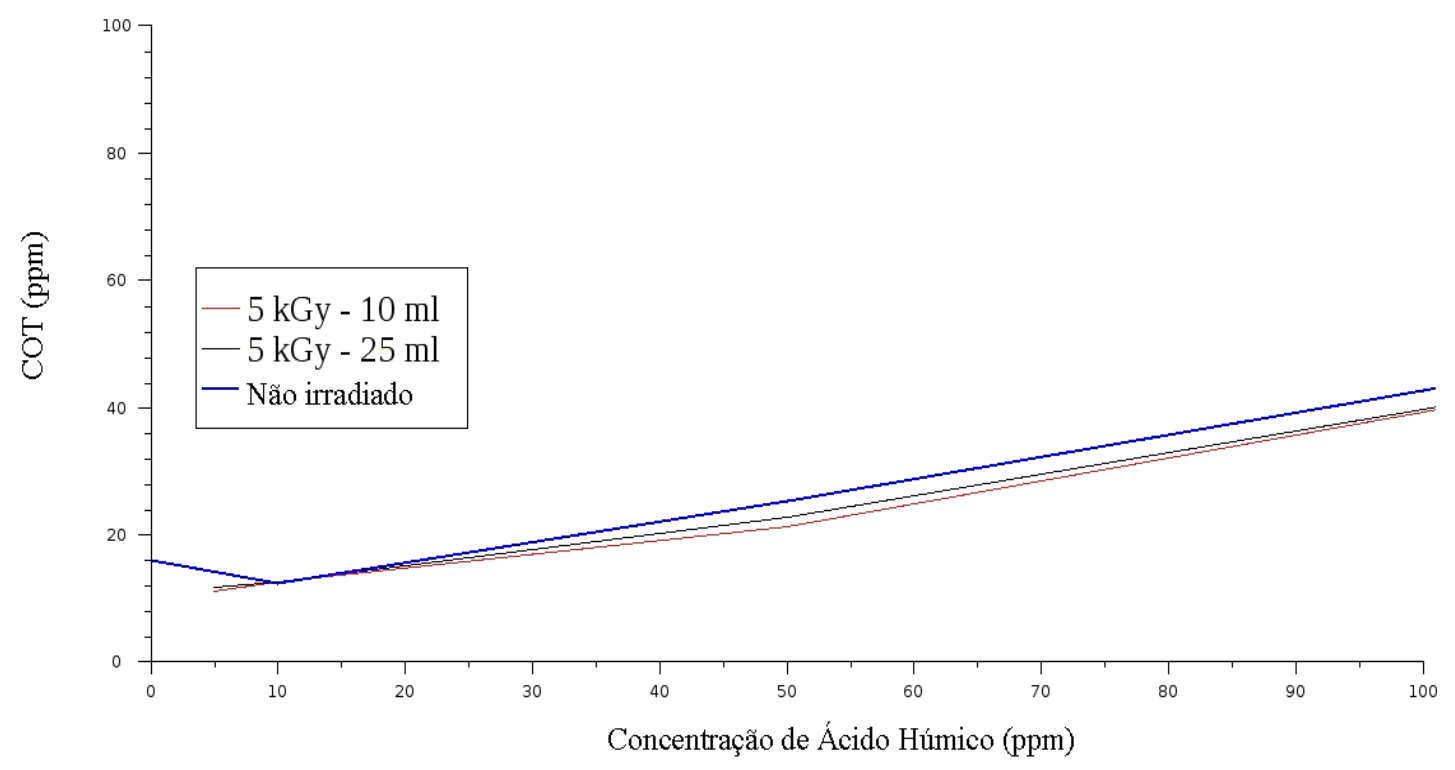

b)

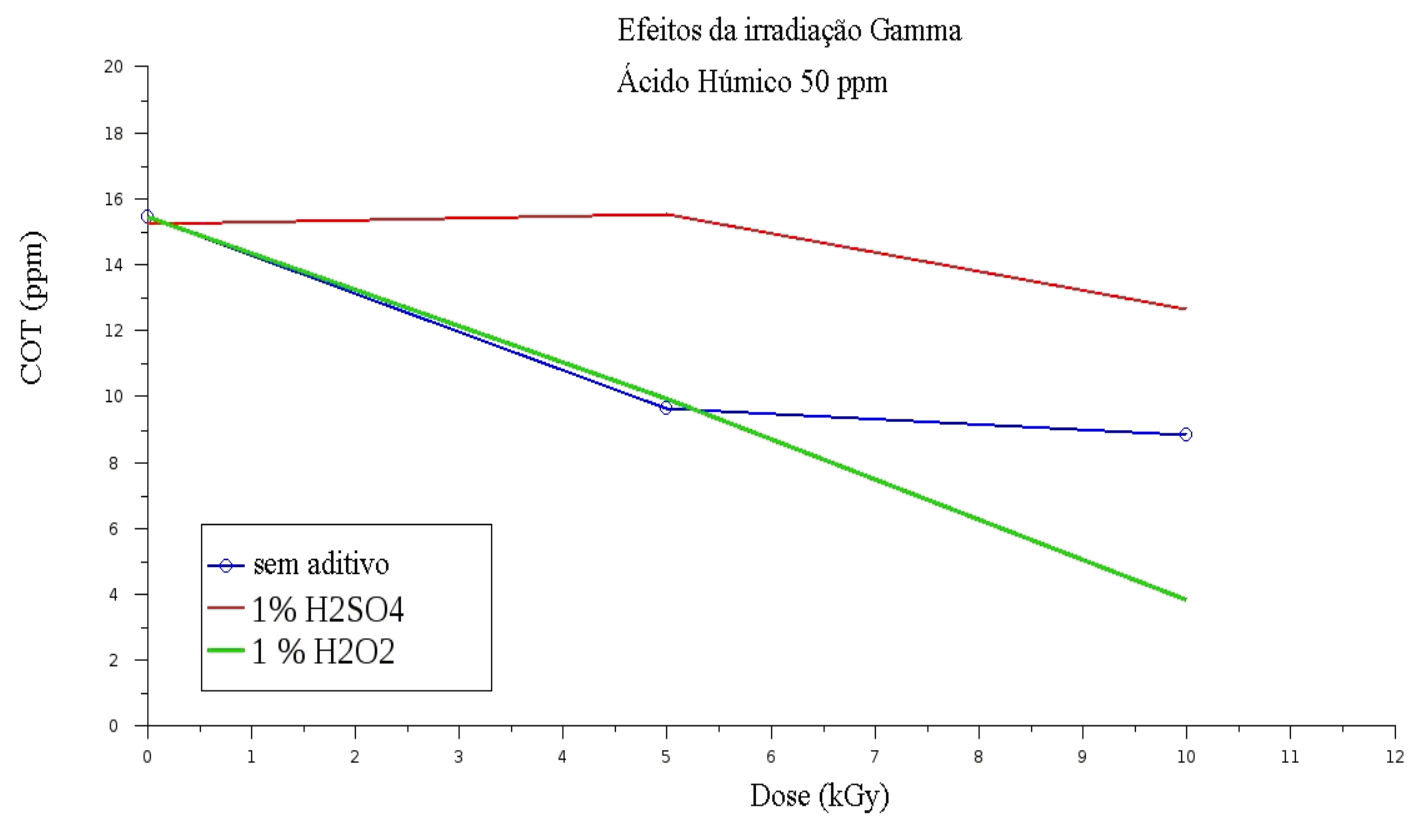

FIGURA 4.6. a) Efeito da radiação gama em distintos volumes de amostra e b) resultado do COT em função da dose absorvida nas amostras com $\mathrm{AH}$ sem aditivos e com os aditivos $\mathrm{H}_{2} \mathrm{O}_{2}$ e $\mathrm{H}_{2} \mathrm{SO}_{4}$ na concentração de $1 \%$. 
Efeitos da irradiação Gamma

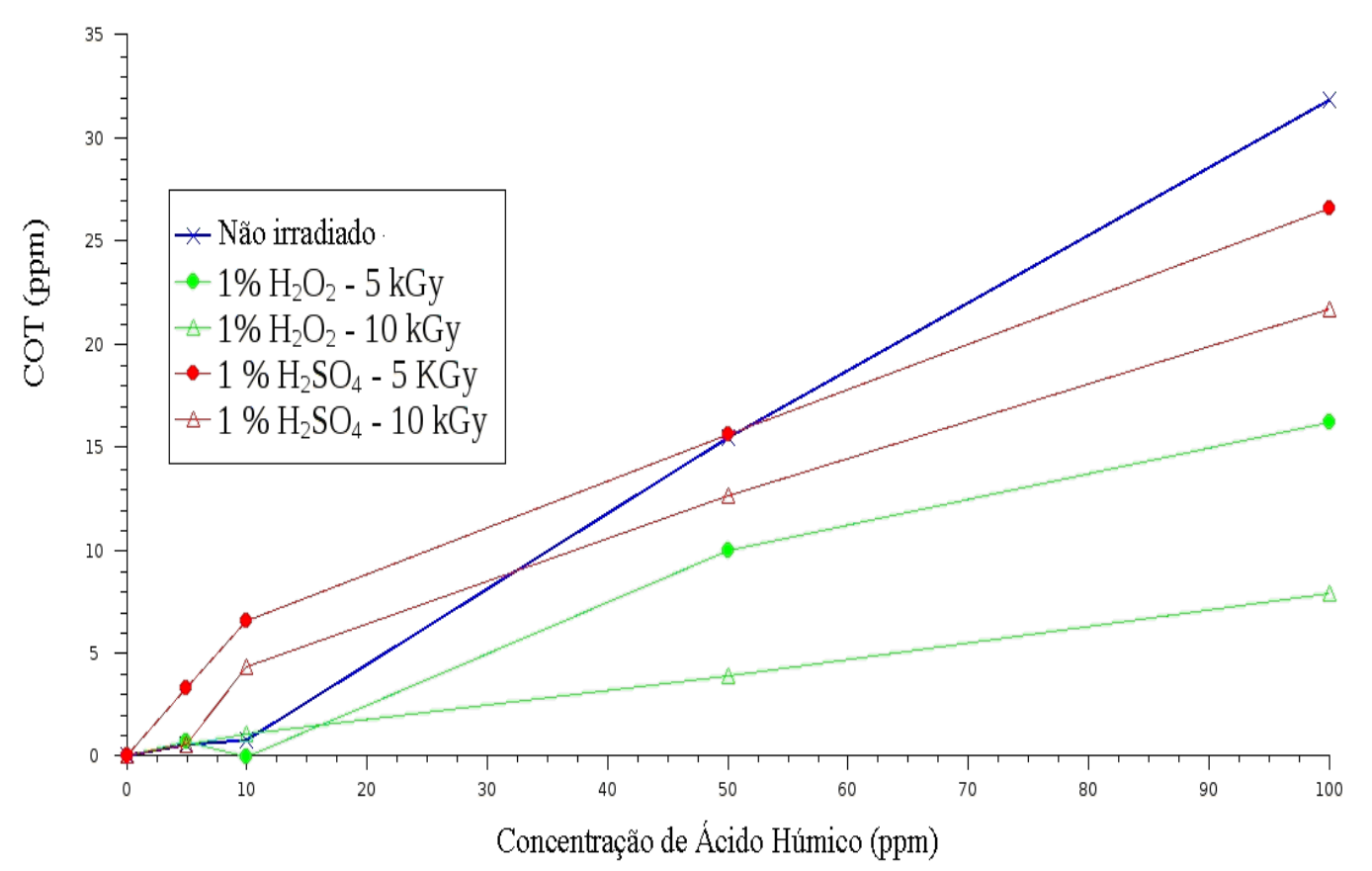

FIGURA 4.7. Resultado do COT sobre o efeito da radiação gama em soluções de ácido húmico com $1 \%$ de $\mathrm{H}_{2} \mathrm{SO}_{4}$ e com $1 \%$ de $\mathrm{H}_{2} \mathrm{O}_{2}$ irradiados em $5 \mathrm{kGy}$ e $10 \mathrm{kGy}$.

Efeitos da irradiação Gamma

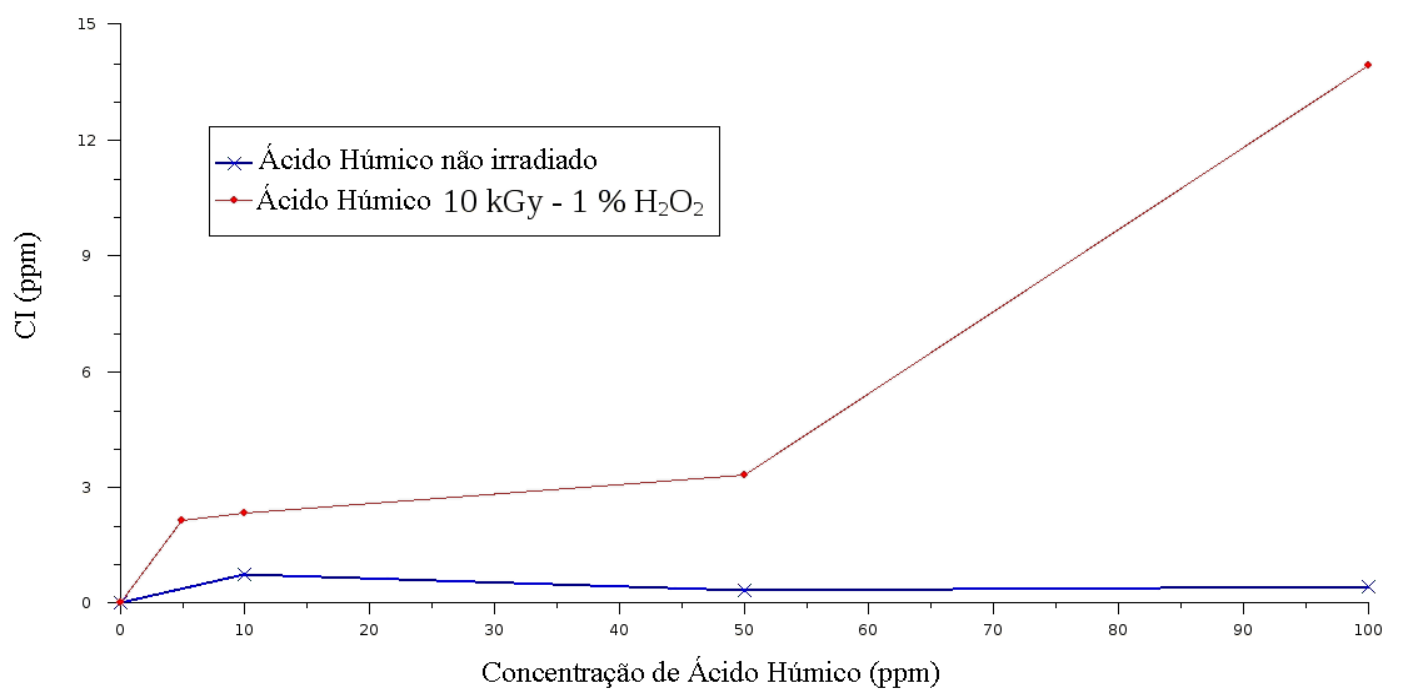

FIGURA 4.8. Teor de CI das soluções de $\mathrm{AH}$ contendo $1 \%$ de $\mathrm{H}_{2} \mathrm{O}_{2}$ irradiadas em $10 \mathrm{kGy}$ comparado ao das soluções de AH não irradiadas e sem aditivos. 


\subsubsection{Análise espectral das soluções de AH}

Segundo a literatura (UYGUNER \& BEKBOLET, 2005), as bandas de absorção no UV-vis do AH são largas, ou seja, há vários comprimentos de onda de absorção para o estudo (250, 254, 270, 280, 300, 365, 400, 436 e $465 \mathrm{~nm})$, bem como os índices relativos de absorção (Abs250/Abs365, Abs465/Abs665); essas condições têm sido citadas na literatura como diferenciação espectral de substâncias húmicas e caracterizam a matéria orgânica em sua forma dissolvida em águas naturais.

No presente trabalho observou-se que a resposta quantitativa nos comprimentos de onda $225 \mathrm{~nm}, 230 \mathrm{~nm}, 250 \mathrm{~nm}, 254 \mathrm{~nm}, 280 \mathrm{~nm}$ e $300 \mathrm{~nm}$ ocorreu nos espectros das soluções de AH sem aditivos (FIG. 4.9), porém na presença dos aditivos $\mathrm{H}_{2} \mathrm{O}_{2}$ e $\mathrm{HNO}_{3}$ a resposta quantitativa desses espectros só é dada no comprimento de onda de $300 \mathrm{~nm}$ ou mais devido à absorção do arranjo molecular dos átomos de oxigênio dos aditivos ser maior e eclipsar a absorção das moléculas de ácido húmico (FIG. 4.14 e 4.15); as soluções contendo $\mathrm{H}_{2} \mathrm{SO}_{4}$ deram resposta quantitativa a partir de $225 \mathrm{~nm}$ (FIG. $4.12 \mathrm{e}$ 4.13).

Soluções aquosas de ácido húmico apresentam aumento de absorção na região do UV (190 nm a $300 \mathrm{~nm}$ ) mesmo em baixas concentrações (5 ppm e 10 ppm - FIG. 4.9b); acima de 250 ppm (FIG. 4.9a), a absorção da radiação UV nessa região é muito alta, o que impossibilita o registro das informações nessa faixa de comprimento de onda e até mesmo na faixa de radiação visível, como é o caso da solução de AH na concentração de 1.000 ppm, cujas informações espectrais estão registradas em comprimentos de onda acima de $450 \mathrm{~nm}$.

No entanto, quando estas soluções são submetidas ao processo de irradiação gama, o comportamento quanto à absorção de radiação UV muda: em baixa dose (FIG. 4.10a), há uma tendência na diminuição da absorbância principalmente em soluções com baixa concentração de AH; quando a dose aumenta para 60 kGy (FIG. 4.10b), observa-se maior diminuição da absorbância até mesmo em 1.000 ppm de concentração de AH em relação às mesmas soluções irradiadas na dose de $5 \mathrm{kGy}$. 
a)

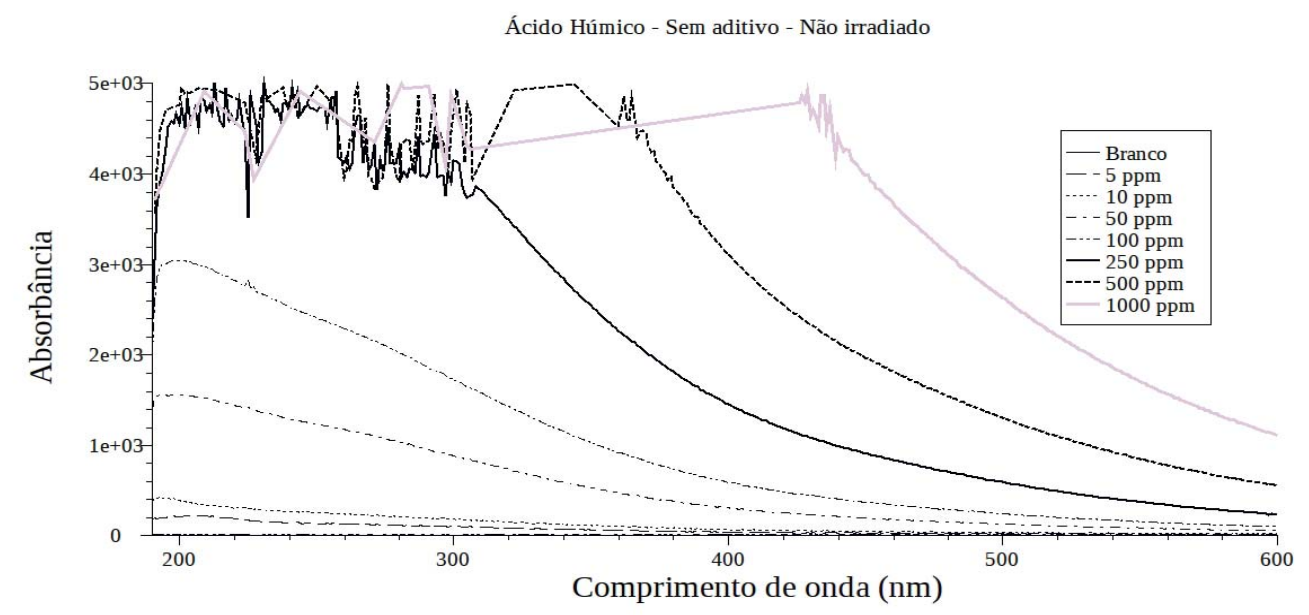

b)

Ácido Húmico - Sem aditivo - Não irradiado

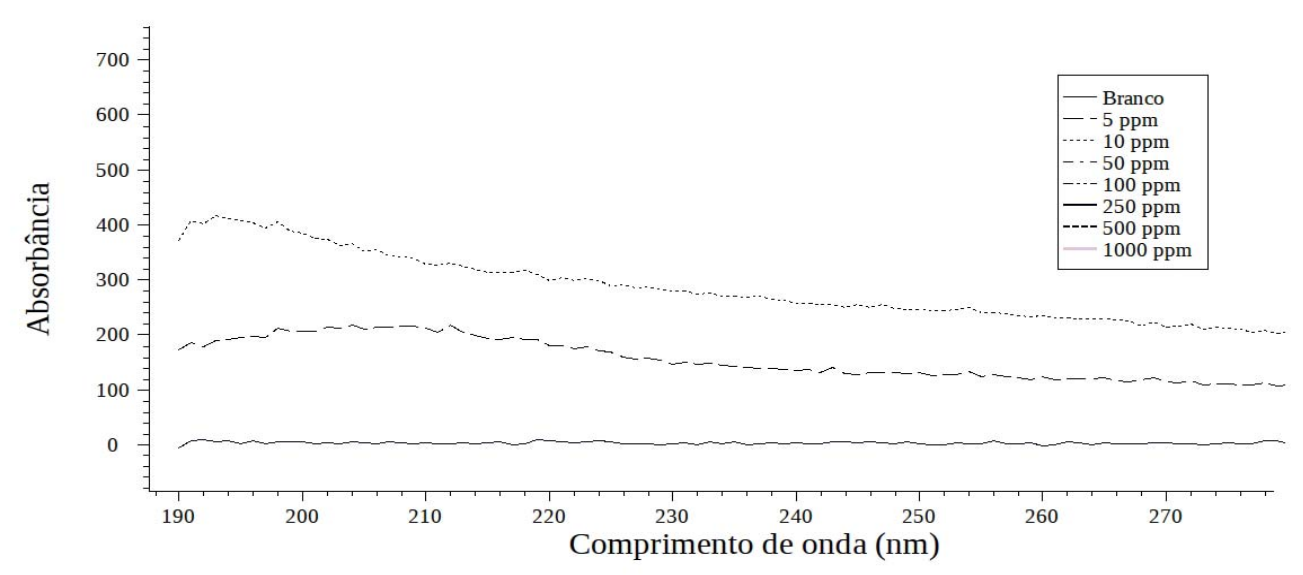

FIGURA 4.9. Espectros de UV-vis de soluções aquosas de ácido húmico. a) todas as concentrações estudadas e b) Detalhe dos espectros das concentrações mais baixas. 
a)

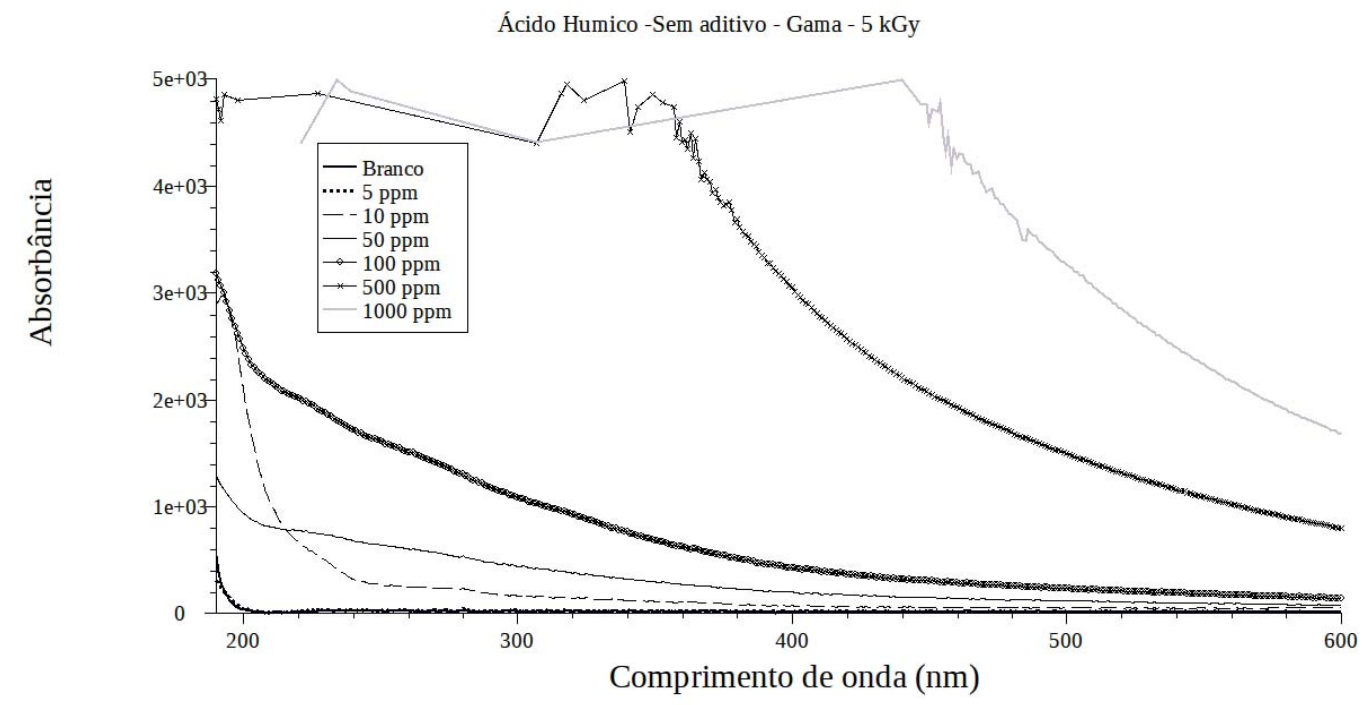

b)

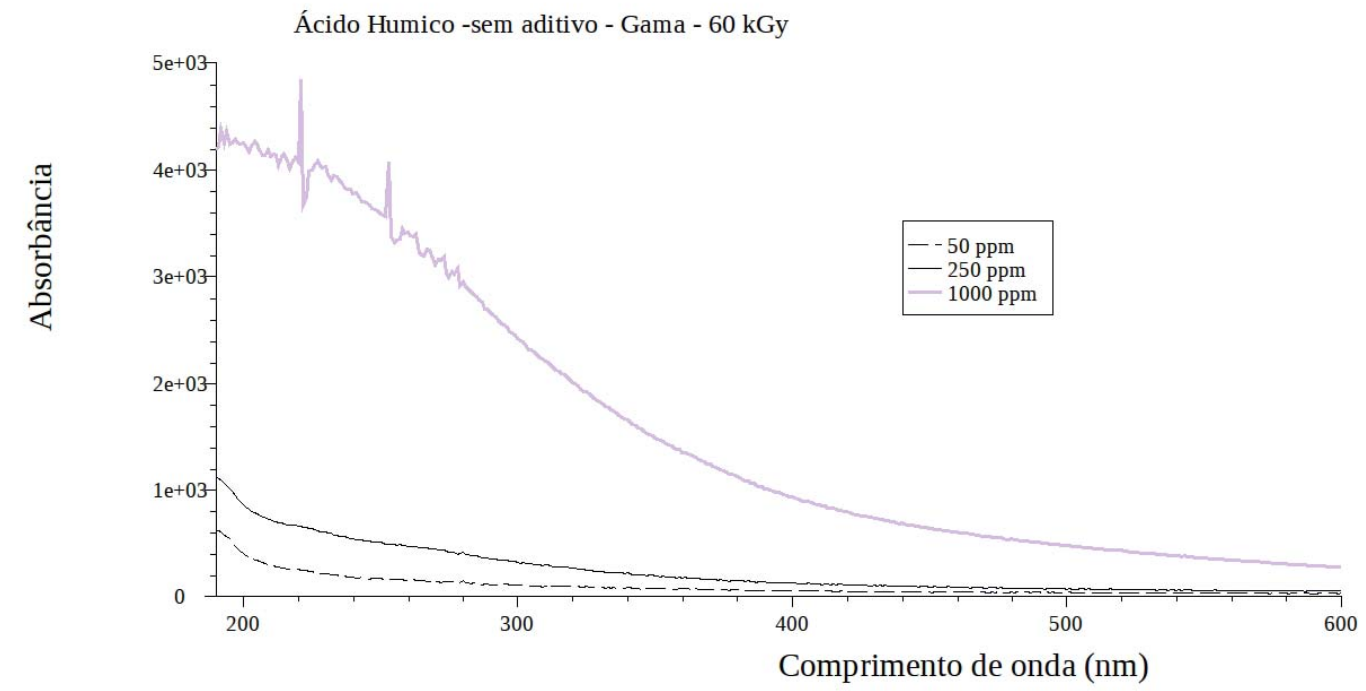

FIGURA 4.10. Espectros de UV-vis das soluções aquosas de ácido húmico após o processo de irradiação gama a) 5 kGy e b) 60 kGy. 


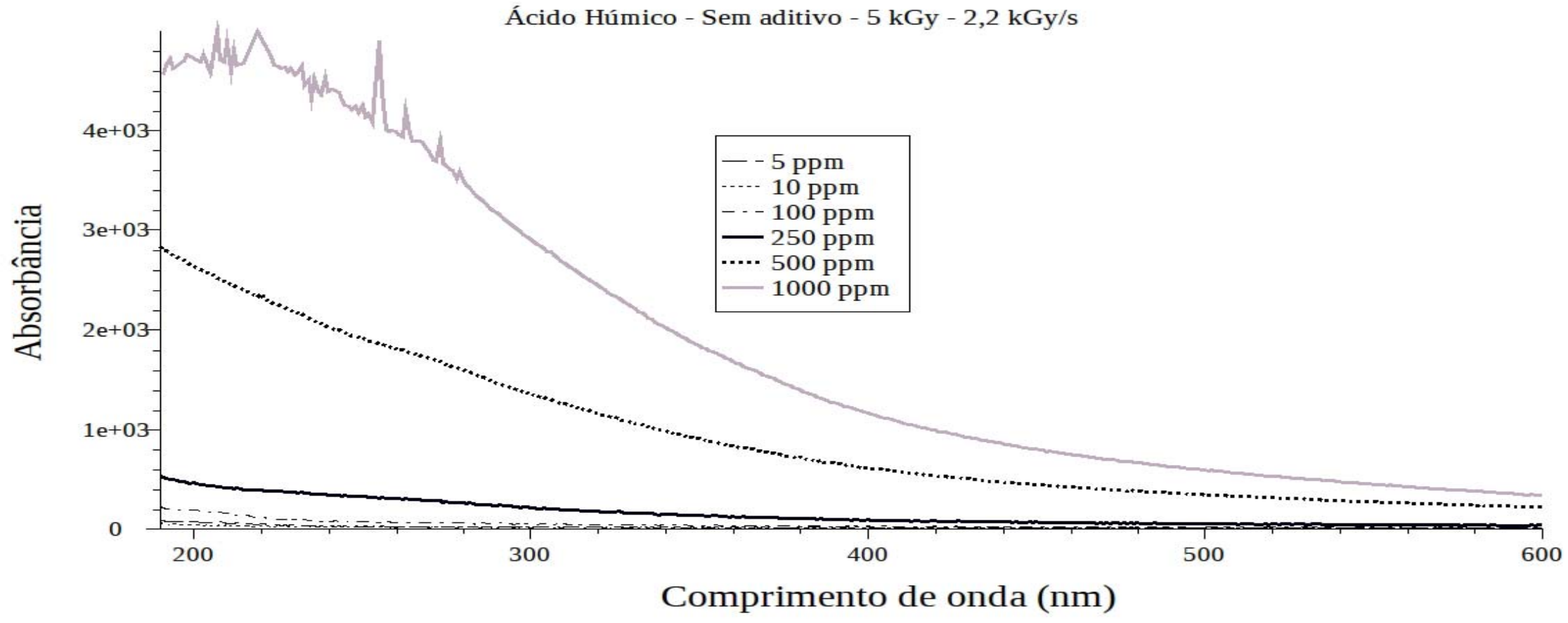


b)

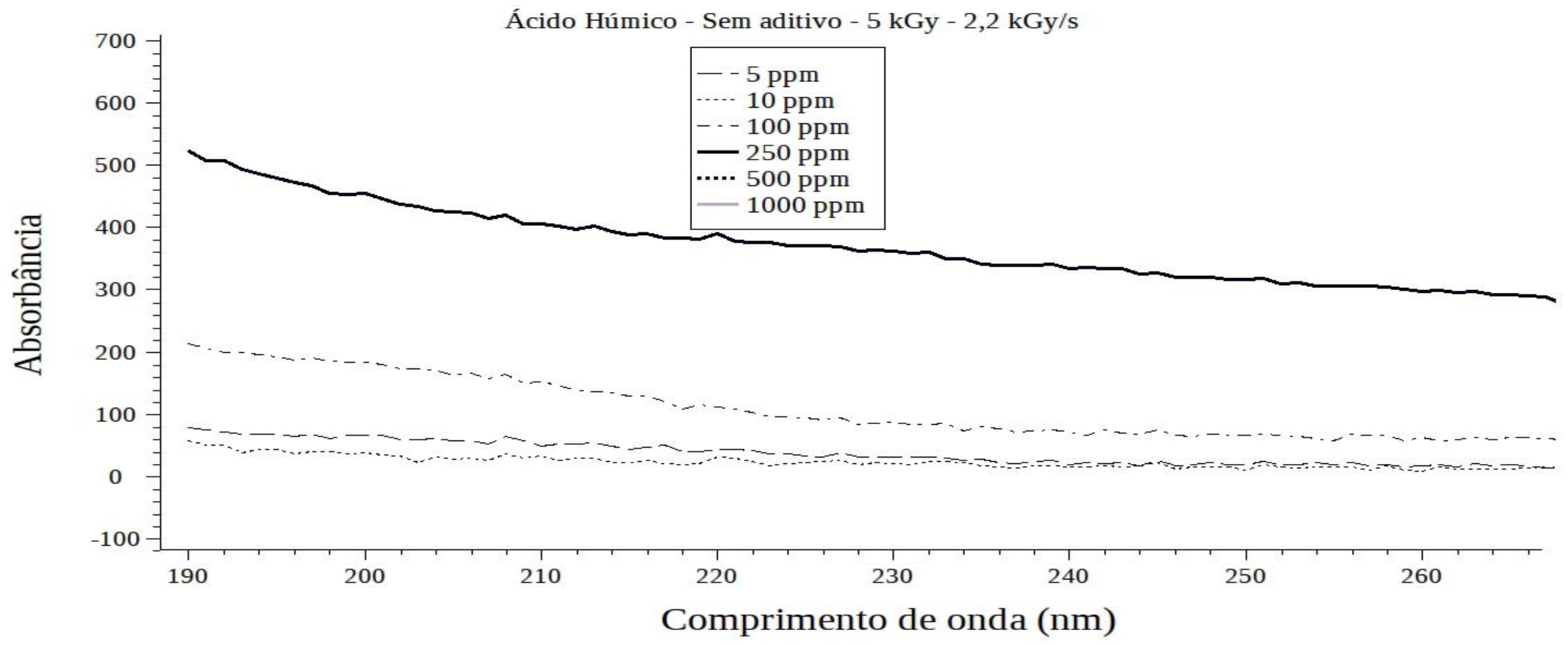


c)

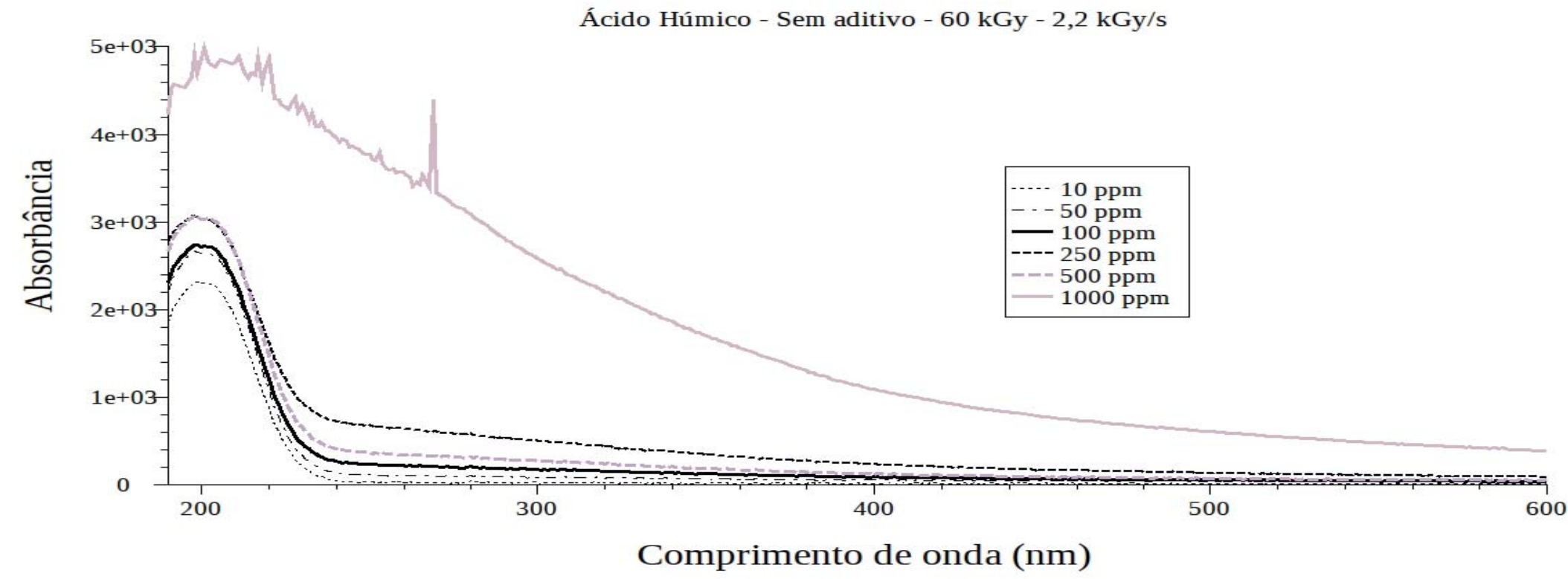

FIGURA 4.11. Espectros de UV-vis das soluções aquosas de ácido húmico após o processo de irradiação por feixe de elétrons na taxa de dose de 2,2 kGy/s e nas seguintes doses absorvidas: a) $5 \mathrm{kGy}$, b) $5 \mathrm{kGy}$ - detalhes em concentrações mais baixas e c) $60 \mathrm{kGy}$. 
Ácido Húmico - Aditivo: 1 \% $\mathrm{H}_{2} \mathrm{SO}_{4}$ - Não irradiado

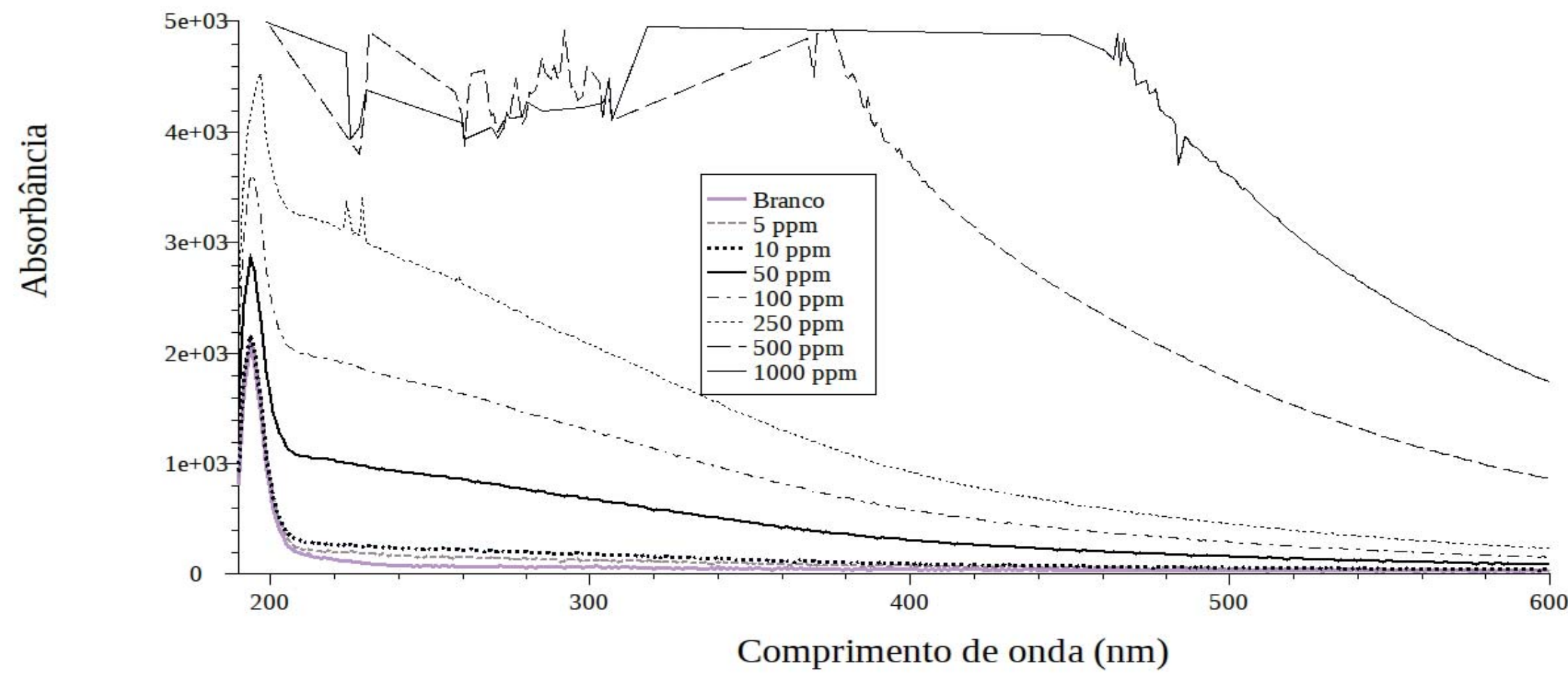


b)

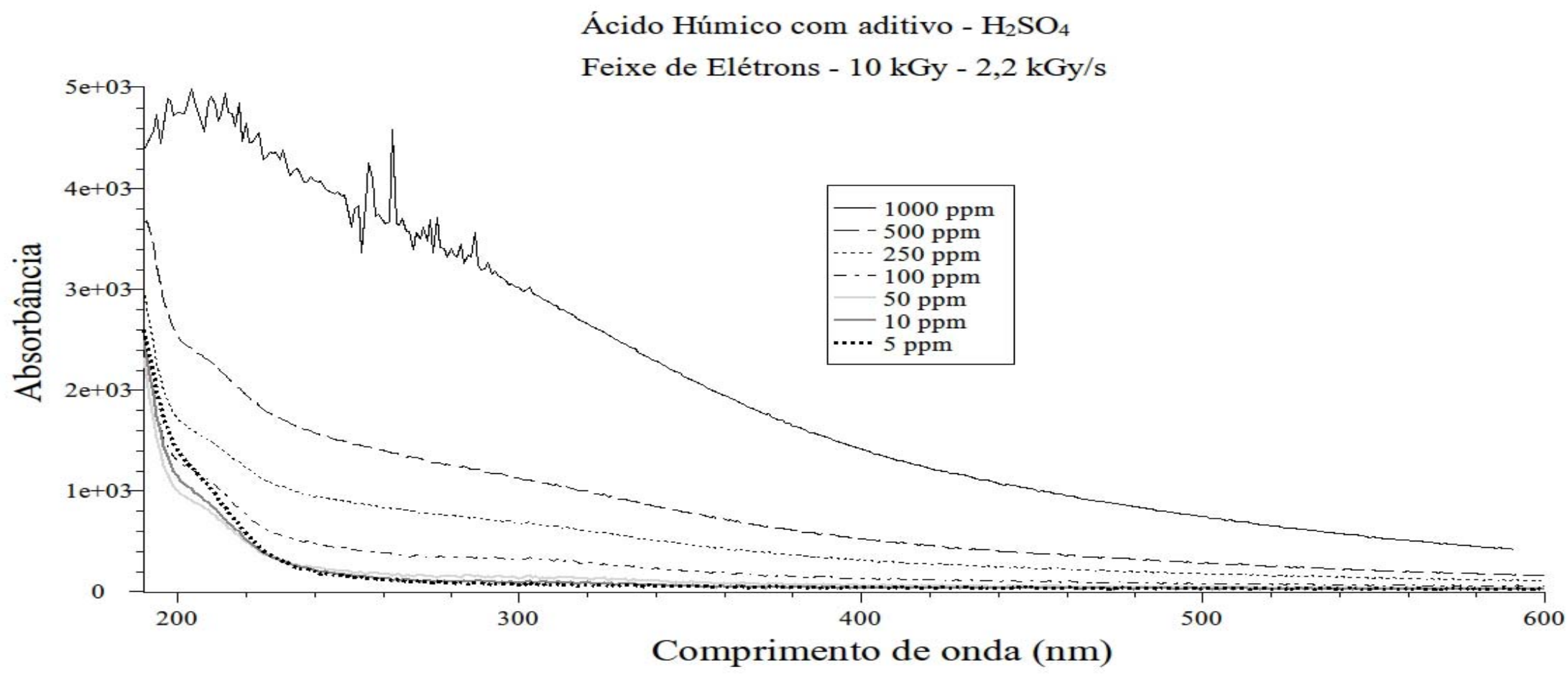


c)

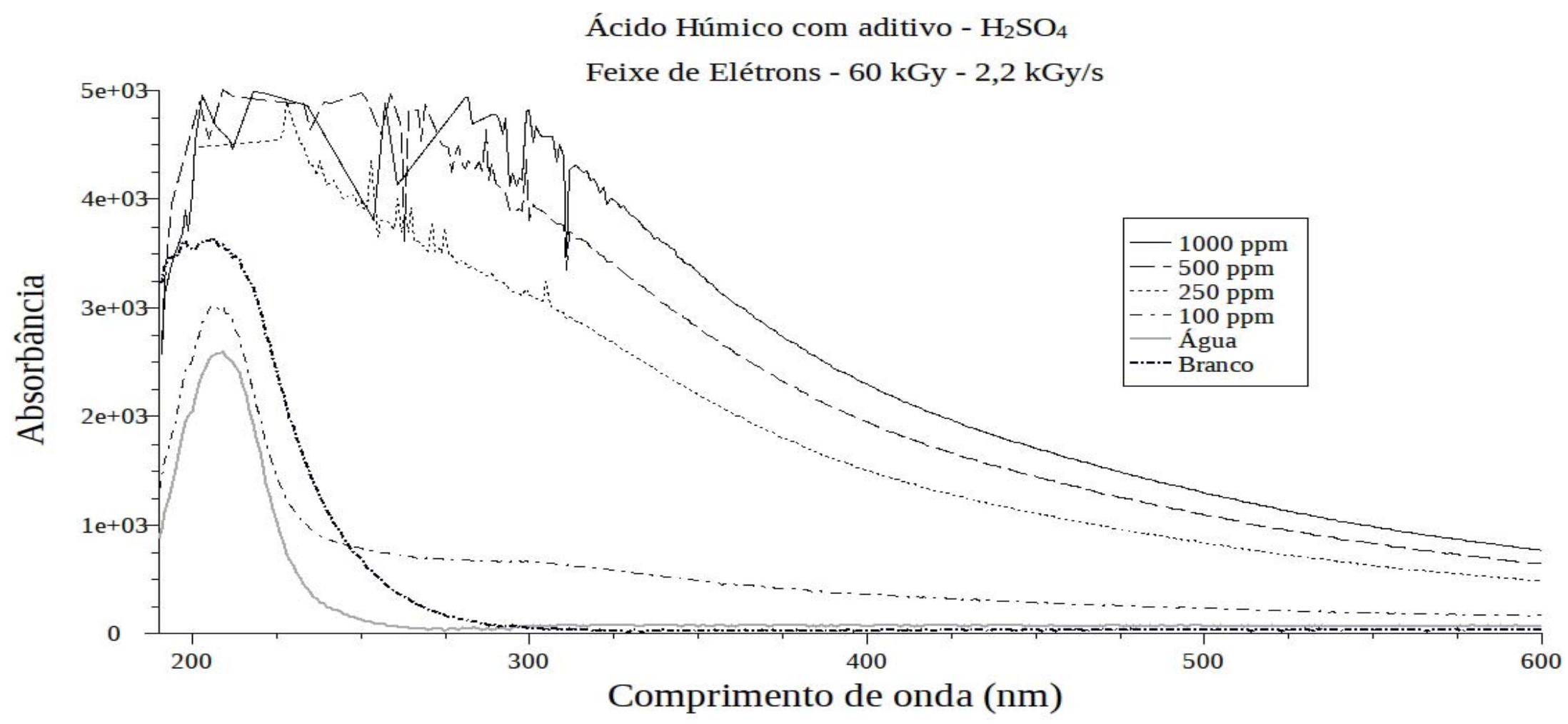

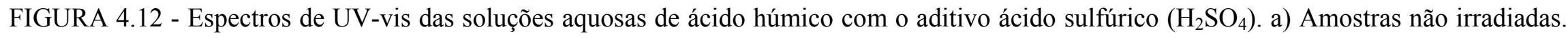
Amostras irradiadas sob feixe de elétrons na taxa de dose de 2,2 kGy/s e doses de: b) $10 \mathrm{kGy}$ e c) $60 \mathrm{kGy}$. 
a)

Ácido Húmico com aditivo $-\mathrm{H}_{2} \mathrm{SO}_{4}$

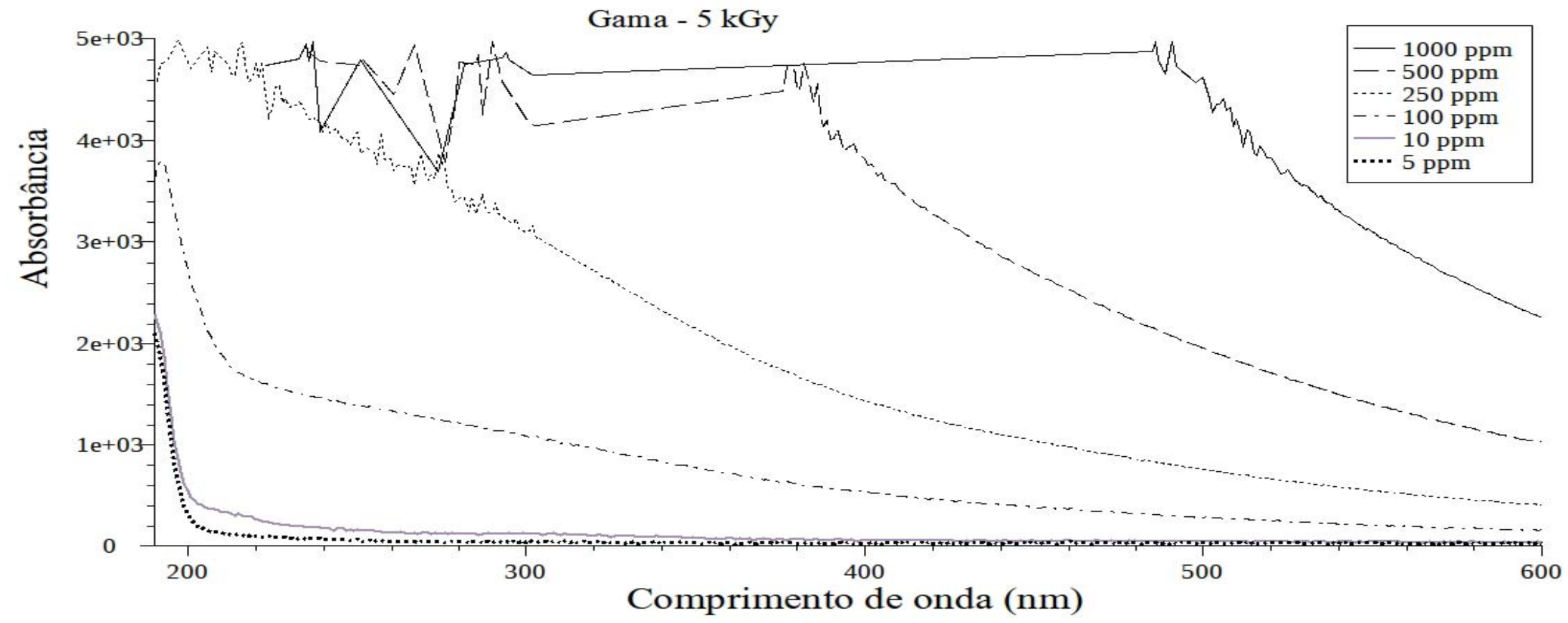


b)

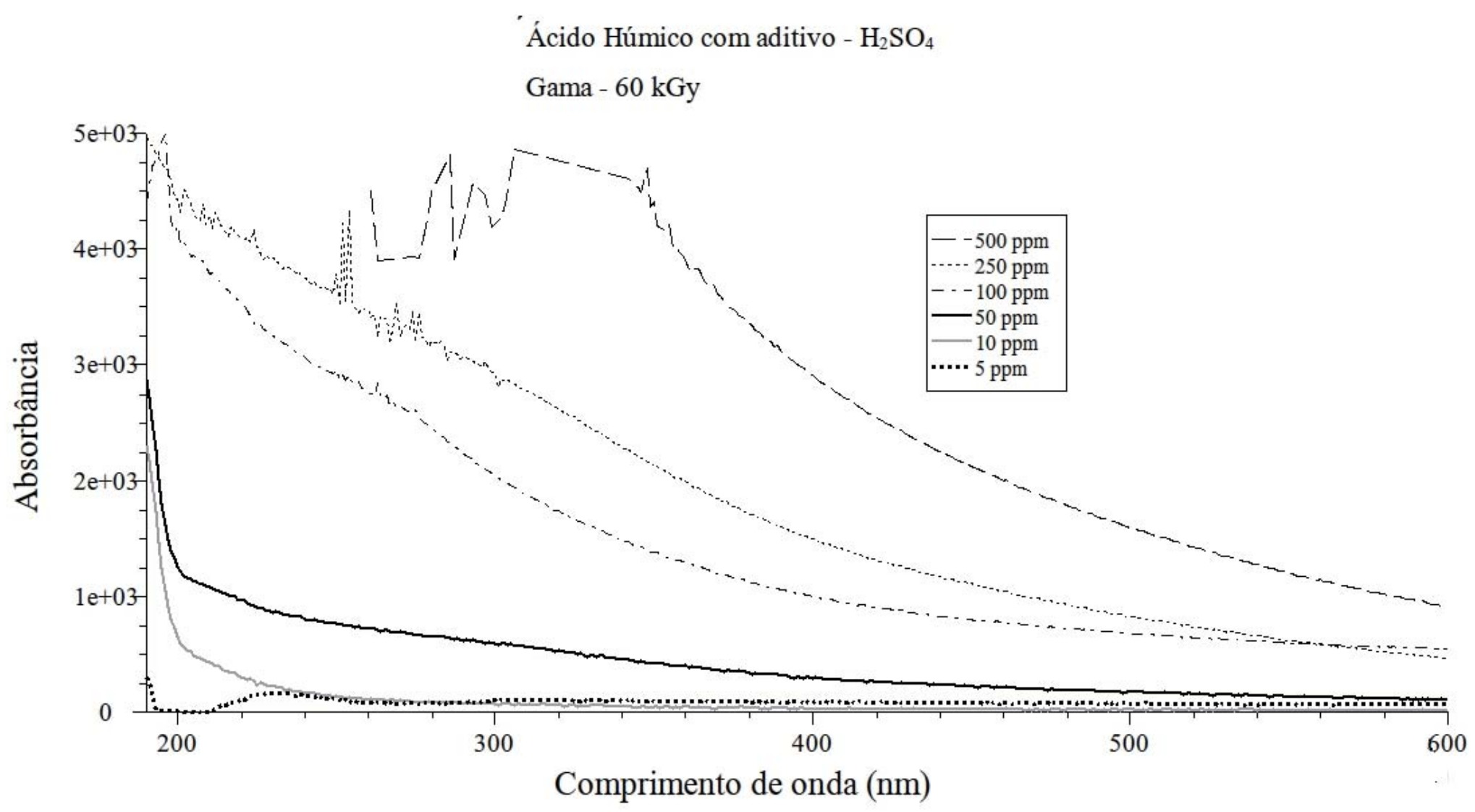

FIGURA 4.13 - Espectros de UV-vis das soluções aquosas de ácido húmico com o aditivo $\mathrm{H}_{2} \mathrm{SO}_{4}$. Processo de irradiação gama: a) dose absorvida de 5 kGy e b) dose absorvida de 60 kGy. 
A FIG. 4.11 mostra os espectros das soluões de AH sem aditivos submetidas ao processo de irradiação por feixe de elétrons. Nesse caso, observa-se que quando o sistema absorve uma dose de 5 kGy (FIG. 4.11a), a absorbância dos espectros nos comprimentos de onda característicos do AH diminui consideravelmente, notando-se que na concentração de 1.000 ppm é possível obter informações a partir de 300 nm, o que não era possível comparando-se com os espectros dessas soluções não irradiadas (FIG. 4.9). Nas soluções cujas concentrações são mais baixas, a absorbância na faixa de $190 \mathrm{~nm}$ a $260 \mathrm{~nm}$ ficou tão baixa que o espectro da solução contendo 10 ppm de AH tem valores de absorbância muito próximos aos do espectro da solução de AH com 5 ppm de concentração (FIG. 4.11b).

a)

Ácido Húmico - Aditivo: $1 \% \mathrm{H}_{2} \mathrm{O}_{2}$ - Não irradiado

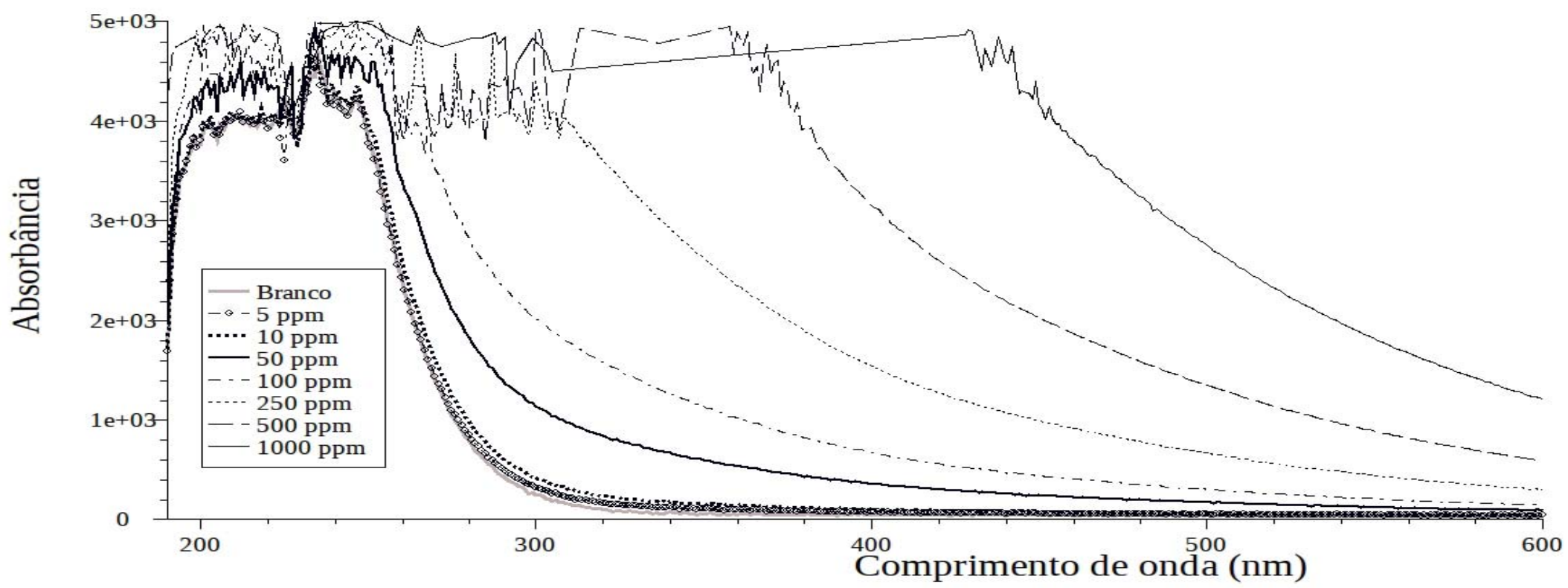


b)

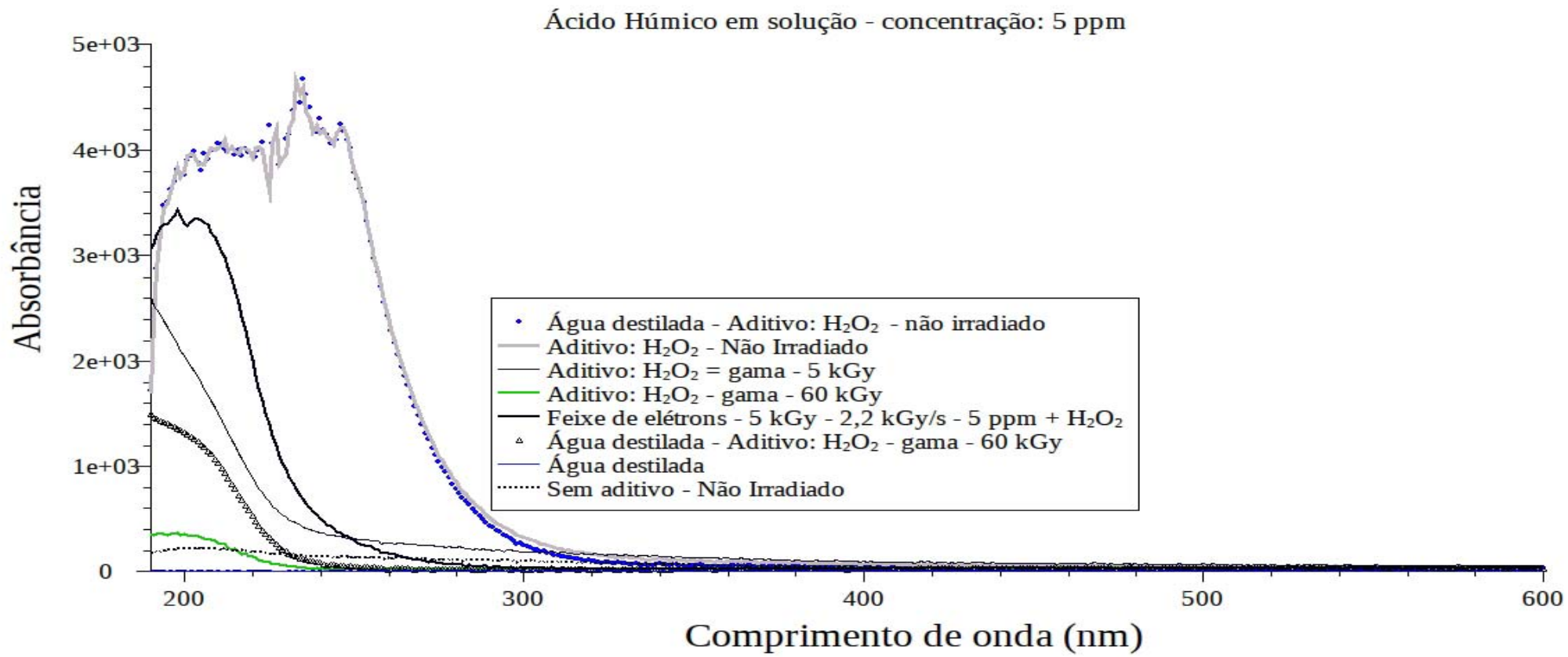

FIGURA 4.14. Espectros de UV-vis das soluções aquosas de ácido húmico com água oxigenada $\left(\mathrm{H}_{2} \mathrm{O}_{2}\right)$. a) Amostras não irradiadas; b) solução de 5 ppm de AH em várias situações: com aditivo e não irradiado, com aditivo e irradiado sob raios gama nas doses 5 kGy e $60 \mathrm{kGy}$ e sob feixe de elétrons na dose de $5 \mathrm{kGy}$ e taxa de dose $2,2 \mathrm{kGy} / \mathrm{s}$; comparação com os espectros da solução de AH 5 ppm sem aditivo e não irradiada e com os brancos não irradiados (água destilada com e sem esse aditivo) e irradiado (água destilada com aditivo irradiado sob raios gama na dose de 60 $\mathrm{kGy}$ ). 
Quando a dose absorvida do processo por feixe de elétrons aumenta para 60 kGy e na mesma taxa de dose (2,2 kGy/s - FIG. 4.11c), verifica-se a diminuição da absorbância nos espectros das soluções de até 500 ppm, sendo que as informações desses espectros estão contidas em comprimentos de onda maiores que $250 \mathrm{~nm}$. Abaixo desse valor de comprimento de onda observa-se um máximo de absorção que sugere a formação de alguma espécie química que interfere na avaliação desses resultados; o espectro da solução de 1.000 ppm de AH começa a ter informações em comprimentos de onda acima de $280 \mathrm{~nm}$ nessas condições. Segundo estudo de Seriesi et al. (1977), quando se irradiam soluções de $\mathrm{AH}$ cujos valores de $\mathrm{pH}$ variam de 2 a 7 , seja por radiação gama ou por feixe de elétrons, há tanto a formação de agregados de $\mathrm{AH}$ como também a de radicais oxigenados que conduzem à formação de água oxigenada. Sendo assim, sabendo-se que as soluções utilizadas nesse trabalho tinham $\mathrm{pH}$ entre 5 e 6 , é possível que tenha havido a formação de subprodutos, que pode até mesmo ser íons peróxido provenientes da radiólise da água destilada e da água oxigenada.

Os resultados das FIG. 4.10 e 4.11 mostram que o processo de irradiação diminui a concentração de $\mathrm{AH}$, sendo que os processos desenvolvidos sob baixos valores de dose absorvida são mais efetivos. O processo por feixe de elétrons realizado em baixa dose foi aquele que apresentou os menores valores de absorbância nas soluções em todas as concentrações estudadas.

A FIG. 4.12a mostra os espectros das soluções de ácido húmico em distintas concentrações contendo como aditivo $1 \%(\mathrm{v} / \mathrm{v})$ de ácido sulfúrico. Esses espectros mostram o aumento da absorbância em função do aumento da concentração de AH e que é visível na faixa de comprimento de onda acima de $210 \mathrm{~nm}$; abaixo desse valor observa-se um pico referente à absorção do aditivo. Nessas condições ainda, observa-se que os espectros das soluções com concentração acima de 500 ppm têm mais informações somente a partir de $400 \mathrm{~nm}$ - abaixo desse valor de comprimento de onda as soluções apresentam interferência devido à alta absorção da radiação UV-vis.

As FIG. 4.12b e 4.12c mostram o comportamento espectral das soluções de $\mathrm{AH}$ contendo $\mathrm{H}_{2} \mathrm{SO}_{4}$ e irradiadas sob o feixe de elétrons (taxa de dose 2,2 kGy/s). Todas as soluções apresentaram diminuição na absorbância, porém, em baixa dose os espectros começam a ter informações efetivas a partir de $250 \mathrm{~nm}$; entre $200 \mathrm{~nm}$ e $220 \mathrm{~nm}$ observa-se a presença de um ombro no espectro que sugere a formação de subprodutos. 
Com o aumento da dose para 60 kGy, observa-se menor absorbância em concentrações mais baixas de $\mathrm{AH}$, porém os espectros apresentam informações efetivas somente em comprimentos de onda acima de $300 \mathrm{~nm}$, já que há um grande pico de absorção em valores de comprimento de onda abaixo de $300 \mathrm{~nm}$ (indicativo de formação de subprodutos). Concentrações mais altas de AH nesse valor de dose tiveram maior absorbância do que as concentrações correspondentes irradiadas em uma dose menor. Esse comportamento espectral sugere mais uma vez que essas condições de irradiação não foram adequadas devido à formação de subprodutos interferentes.

Quando se utiliza a irradiação gama com o objetivo de mineralizar as soluções de AH (FIG. 4.13), observa-se que em baixa dose (5kGy - FIG. 4.13a), os espectros correspondentes às soluções de concentração mais baixa apresentam menor absorbância em relação às soluções contendo o mesmo tipo de aditivo $\left(\mathrm{H}_{2} \mathrm{SO}_{4}\right)$ e não irradiadas; pouco efeito sobre a diminuição da absorbância é observado nas soluções com concentração mais alta de AH. O aumento da dose para 60 kGy conduz à diminuição da absorbância em todos os espectros analisados comparados ao mesmo caso dessas soluções não submetidas ao processo de irradiação. No entanto, na faixa de comprimento de onda entre $220 \mathrm{~nm}$ e $240 \mathrm{~nm}$ observa-se ainda um pequeno ombro nos espectros das soluções com concentração entre 5 ppm e 50 ppm e em 280 nm o início de um ombro no espectro da solução contendo 100 ppm de AH, sugerindo a formação de subprodutos devido o processo de irradiação.

O processo de irradiação também foi aplicado em soluções contendo os aditivos água oxigenada $\left(\mathrm{H}_{2} \mathrm{O}_{2}\right)$ e ácido nítrico $\left(\mathrm{HNO}_{3}\right)$. Utilizando como aditivo o peróxido de hidrogênio $\left(\mathrm{H}_{2} \mathrm{O}_{2}\right)$, observa-se que os espectros das soluções contendo $\mathrm{AH}$ em distintas concentrações somente apresentam informações em comprimentos de onda maiores que $300 \mathrm{~nm}$., já que há grande absorção na faixa de comprimentos de onda abaixo desse valor devido às moléculas do aditivo (FIG. 4.14a).

O processo de irradiação das amostras de ácido húmico contendo peróxido de hidrogênio mostra resultados interessantes e que estão expressos na FIG. 4.14b. A amostra em branco (água destilada com $\mathrm{H}_{2} \mathrm{O}_{2}$ ), apresenta o mesmo comportamento que a amostra de $\mathrm{AH}$ na concentração 5 ppm contendo $\mathrm{H}_{2} \mathrm{O}_{2}$. Quando a solução de $\mathrm{AH} 5$ ppm é irradiada com raios gama na dose de 5 kGy, observa-se um aumento na absorbância em comprimentos de onda maiores que $240 \mathrm{~nm}$ comparando-se esse espectro com o da mesma solução sem o aditivo e não irradiada; o aumento da dose para 60 kGy mostra que há maior diminuição da absorbância e essas informações podem ser observadas também em comprimentos de onda maiores que $240 \mathrm{~nm}$. Em comprimentos de onda menores que 
$240 \mathrm{~nm}$ há a interferência das moléculas de peróxido, porém observa-se que o processo de irradiação diminuiu a absorbância nessa região se relacionar ao aumento da dose, sugerindo que há um consumo do peróxido durante o processo de irradiação. Essa diminuição da absorbância nessa região também é observada quando se analisa o espectro da água destilada irradiada na dose de $60 \mathrm{kGy}$ (branco do processo) e compara-se com os espectros do branco não irradiado. O processo de irradiação por feixe de elétrons na dose de 5 kGy provoca diminuição da absorbância a partir de comprimentos de onda maiores que $260 \mathrm{~nm}$ e a absorbância nesse caso é menor do que a observada na mesma dose quando o processo ocorre por irradiação gama; no entanto, em comprimentos de onda menores que $260 \mathrm{~nm}$ o pico de absorção do peróxido é ainda alto, sugerindo que no processo de irradiação por feixe de elétrons a formação de subprodutos é maior.

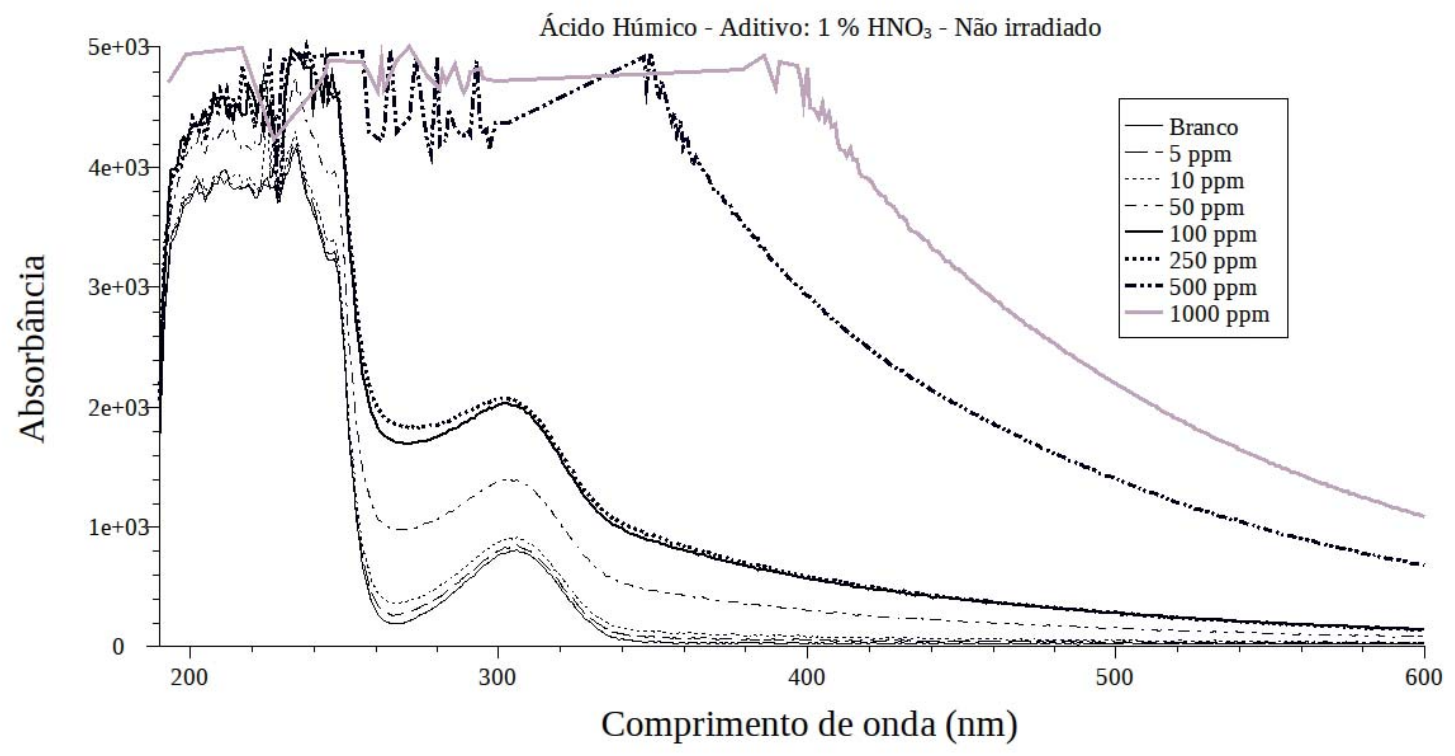

FIGURA 4.15. Espectros de UV-vis das soluções aquosas de ácido húmico com o aditivo ácido nítrico $\left(\mathrm{HNO}_{3}\right)$ e não irradiadas.

A figura 4.15 mostra os espectros das soluções aquosas de $\mathrm{AH}$ em distintas concentrações contendo $\mathrm{HNO}_{3}$ como aditivo. Nesse caso observa-se que as informações dos espectros estão somente na faixa de comprimento de onda correspondente à radiação de luz visível (comprimentos de onda maiores que $350 \mathrm{~nm}$ ), uma vez que abaixo desse valor de comprimento de onda, as moléculas do aditivo têm alta absorção e interferem na análise dos espectros. Os processos de irradiação aplicados nas soluções aquosas de AH 
com esse aditivo mostram sempre esse comportamento sem haver diminuição da absorbância mesmo quando o processo ocorre sob alta dose.

Na prática observou-se que todas as soluções de ácido húmico irradiadas com o peróxido como aditivo apresentaram-se visualmente mais claras ou até mesmo incolores dependendo da concentração de $\mathrm{AH}$ na solução em relação às mesmas soluções irradiadas sem aditivo. Apesar de no item 4.3.1 ter sido mostrado que a mineralização ocorre efetivamente com a adição do peróxido no processo de irradiação (aumento do CI e diminuição do COT), a limitação do método de espectrofotometria UV-vis usado para selecionar o melhor processo de digestão do AH levou à opção de se escolher a irradiação sem a adição de agentes oxidantes $\left(\mathrm{HNO}_{3}, \mathrm{H}_{2} \mathrm{SO}_{4}\right.$ e $\left.\mathrm{H}_{2} \mathrm{O}_{2}\right)$, já que pelo método utilizado não é possível detectar qualitativamente a natureza do interferente, bem como separá-lo por análise espectral. Além disso, a adição de substâncias oxidantes pode introduzir outras substâncias no meio via: a) sua presença na própria substância oxidante (mesmo possuindo grau de pureza adequado) ou b) sua produção no processo de mineralização por irradiação.

\subsubsection{Análise espectral das soluções de $\mathrm{AH}$ contendo íons $\mathrm{Al}^{3+}$}

Na FIG. 4.16, observa-se que o espectro da solução aquosa de ácido húmico na concentração de 1 ppm absorve em todos os comprimentos de onda semelhantemente ao espectro da água destilada, sugerindo que a sensibilidade do método é baixa quando a substância húmica está neste nível de concentração. Já o espectro da solução aquosa de ácido húmico 5 ppm apresenta um aumento de absorbância na faixa de $250 \mathrm{~nm}$ a $280 \mathrm{~nm}$, mostrando que há a absorção de radiação pela substância húmica nessa faixa de comprimento de onda. No entanto, quando se mistura íons alumínio às soluções de ácido húmico a forma dos espectros muda: observa-se absorção máxima em $230 \mathrm{~nm}$ independente da concentração de ácido húmico na solução, o que sugere uma mudança química que pode ser compatível com a formação do produto proveniente da complexação da substância húmica com esse tipo de íon.

O máximo observado em $230 \mathrm{~nm}$ é mais ou menos evidente dependendo da concentração de íons alumínio, como mostram os espectros da FIG. 4.17 - baixas concentrações de íons alumínio (como 0,5 ppm), mostram um máximo menos evidente em todas as concentrações das soluções de ácido húmico utilizadas. 


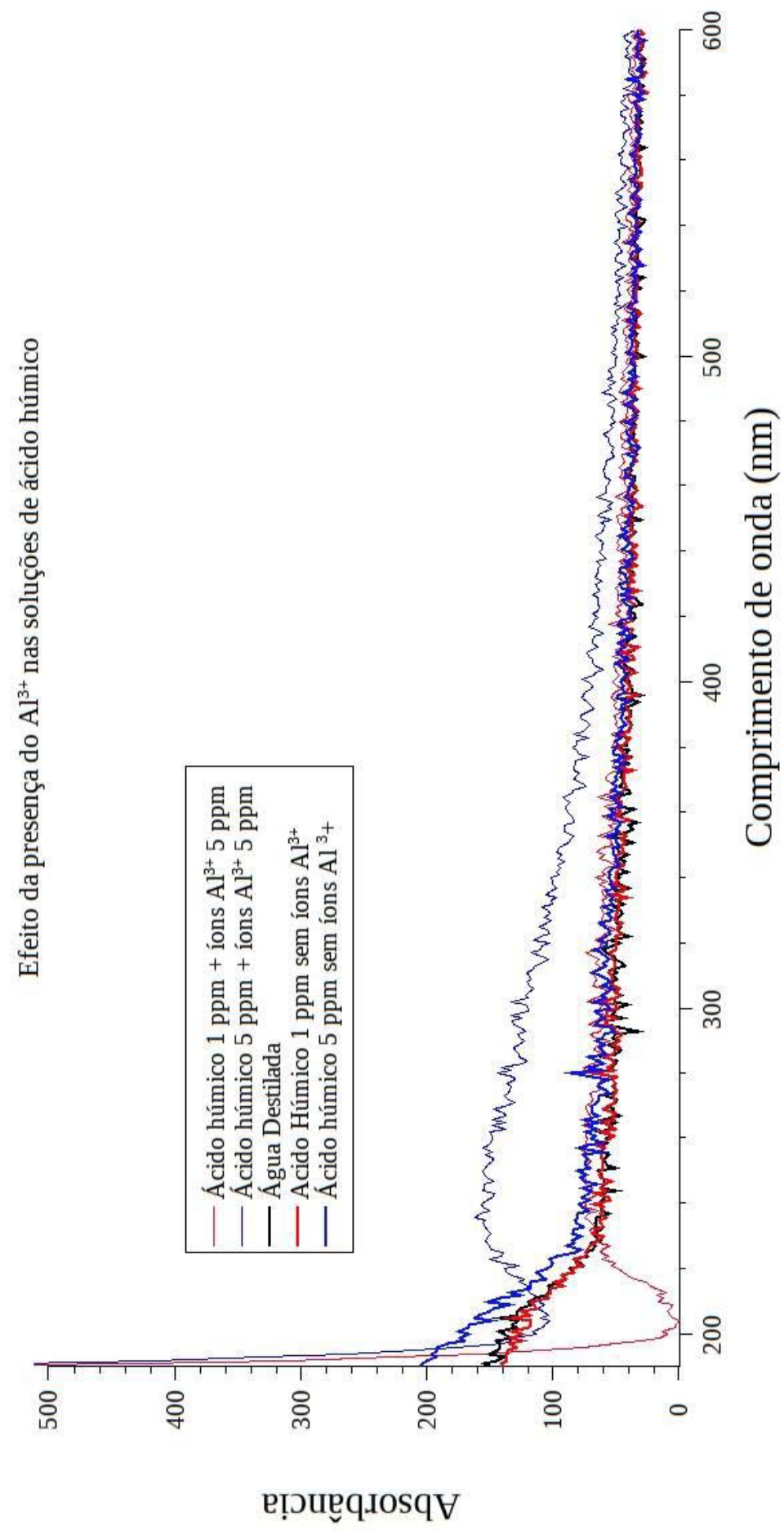

FIGURA 4.16. Espectros de UV-vis das soluções aquosas de ácido húmico nas concentrações 1 ppm e 5 ppm sem íons alumínio e com íons alumínio, comparados com o espectro de água destilada. 


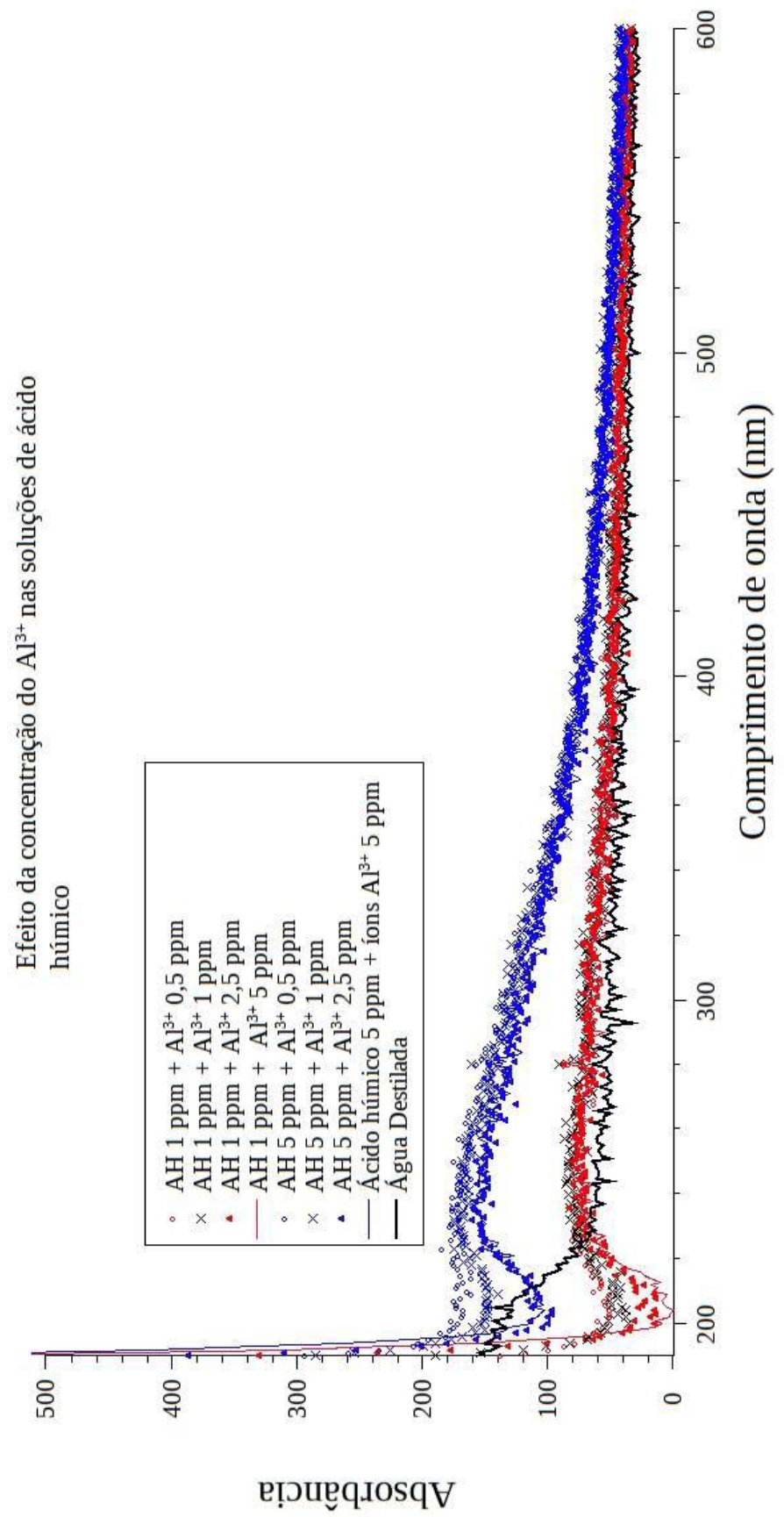

FIGURA 4.17. Espectros de UV-vis das soluções aquosas de ácido húmico nas concentrações 1 ppm e 5 ppm misturados à íons alumínio nas concentrações: 0,5 ppm, 1 ppm, 2,5 ppm e 5 ppm. Comparação com o espectro da água destilada. 
O processo de irradiação altera os espectros de ácido húmico complexado ao alumínio: quando o processo se dá por feixe de elétrons os espectros perdem a elevação máxima em absorbância (FIG. 4.18a) e ficam com o comportamento parecido aos espectros das respectivas soluções de ácido húmico sem a presença de íons alumínio observadas na FIG. 4.16.

a)

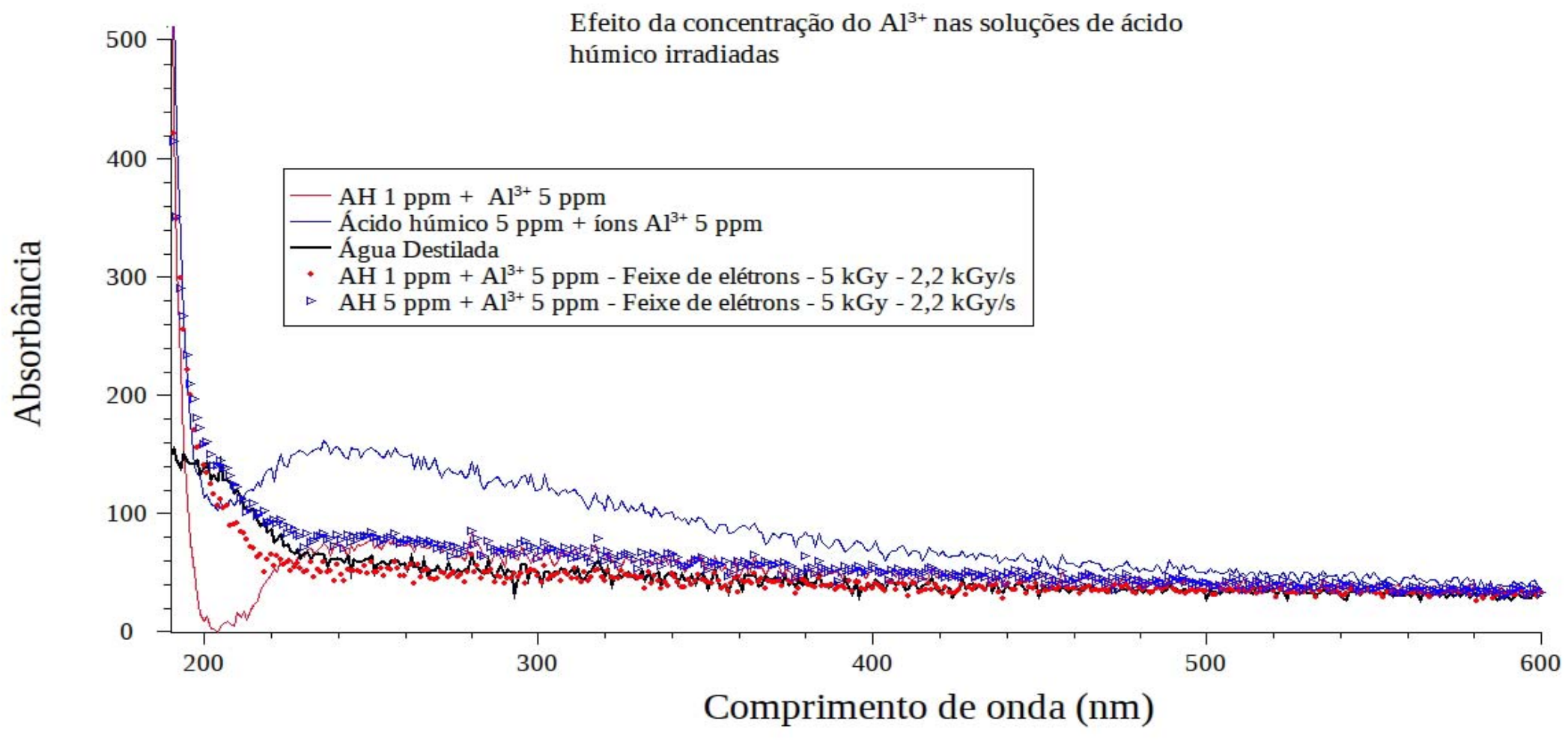


b)

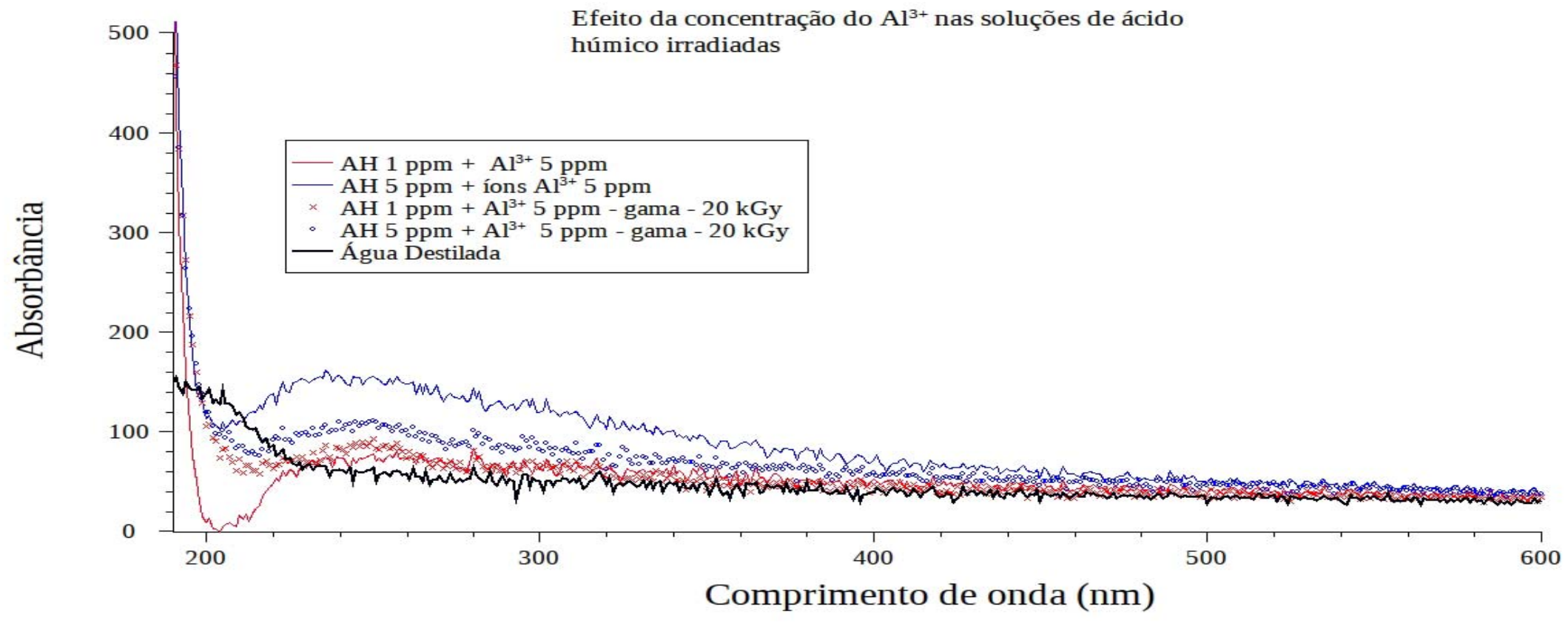

FIGURA 4.18. Espectros de UV-vis das soluções aquosas de ácido húmico nas concentrações 1 ppm e 5 ppm misturados à íons alumínio na concentração de 5 ppm comparados aos espectros das mesmas soluções irradiadas por: a) feixe de elétrons (dose: 5 kGy e taxa de dose: 2,2 $\mathrm{kGy} / \mathrm{s})$ e b) raios gama (dose: $20 \mathrm{kGy}$ ). 
Já com o processo de irradiação gama, os máximos em $230 \mathrm{~nm}$ ainda existem, porém com menor amplitude (FIG. 4.18b). Estes resultados sugerem a desorganização do produto existente antes do processo de irradiação - seja a simples descomplexação, seja a degradação da matéria húmica com a sua consequente descomplexação do ácido húmico. Comparando-se os distintos processos, esses resultados sugerem que a irradiação por feixe de elétrons nas condições efetuadas (taxa de dose: 2,2 kGy/s e dose: $5 \mathrm{kGy}$ ) é mais efetiva que a irradiação por raios gama sob a dose de $20 \mathrm{kGy}$.

\subsubsection{Avaliação da concentração da espécie alumínio em soluções de AH não irradiadas e irradiadas}

As TAB. 4.3 e 4.4 mostram os resultados da determinação da concentração do alumínio, tanto pela técnica de ICP-OES quanto por UV-vis, nas soluções de ácido húmico (1 ppm e 5 ppm) contendo íons alumínio. A quantificação desta espécie química nas soluções não irradiadas mostrou que ambas as técnicas analíticas são suficientes para determinar o alumínio complexado em cada solução, independente da concentração - tanto a tocha de plasma da técnica ICP-OES quanto a reação de coloração caracterísitica para quantificar o alumínio por UV-vis, são metodologias eficientes para a quantificação da espécie química em questão. Neste sentido, a reação de complexação dos íons alumínio com a substância cianina de eriocromo $\mathrm{R}$ é extremamente rápida e o produto formado é altamente estável (VOGEL, 1989).

Realizando as mesmas metodologias para a determinação de alumínio nas mesmas soluções irradiadas, os resultados são semelhantes. Desta forma, todos os resultados apresentados nessas tabelas sugerem que não é necessária a aplicação do processo de mineralização às soluções de ácido húmico complexadas aos íons alumínio. 
TABELA 4.2 - Determinação da concentração de alumínio por ICP-OES nas soluções de ácido húmico nas concentrações de 1 ppm e 5 ppm contendo distintas concentrações de íons alumínio.

\begin{tabular}{|c|c|c|c|c|}
\hline $\begin{array}{l}\text { Tipo de } \\
\text { Radiação }\end{array}$ & $\begin{array}{c}\text { Dose absorvida } \\
(\mathrm{kGy}) / \text { Taxa de } \\
\text { dose }(\mathrm{kGy} / \mathrm{s})\end{array}$ & $\begin{array}{l}\text { Concentração de } \\
\text { ácido húmico } \\
\text { (ppm) }\end{array}$ & $\begin{array}{l}\text { Concentração de } \\
\text { alumínio } \\
\text { (ppm) }\end{array}$ & $\begin{array}{c}\text { Resultado } \\
\text { Analítico por } \\
\text { ICP-OES (ppm) }\end{array}$ \\
\hline \multirow{4}{*}{ Não Irradiado } & \multirow{4}{*}{0} & \multirow{2}{*}{1} & 0,5 & 0,40 \\
\hline & & & 5 & 4,81 \\
\hline & & \multirow{2}{*}{5} & 0,1 & 0,10 \\
\hline & & & 5 & 5,52 \\
\hline \multirow{4}{*}{ Gama } & \multirow{4}{*}{$20 / 1,33$} & \multirow{2}{*}{1} & 2,5 & 2,00 \\
\hline & & & 5 & 5,52 \\
\hline & & \multirow{2}{*}{5} & 2,5 & 2,56 \\
\hline & & & 5 & 5,39 \\
\hline \multirow{11}{*}{$\begin{array}{l}\text { Feixe de } \\
\text { Elétrons }\end{array}$} & \multirow{5}{*}{$5 / 2,2$} & \multirow[b]{2}{*}{1} & 0,5 & 0,32 \\
\hline & & & 5 & 5,47 \\
\hline & & \multirow{3}{*}{5} & 0,1 & 0,06 \\
\hline & & & 2,5 & 2,16 \\
\hline & & & 5 & 4,36 \\
\hline & \multirow{6}{*}{$10 / 2,2$} & \multirow{2}{*}{1} & 2,5 & 2,87 \\
\hline & & & 5 & 4,51 \\
\hline & & \multirow{4}{*}{5} & 0,1 & 0,11 \\
\hline & & & 0,5 & 0,40 \\
\hline & & & 2,5 & 2,74 \\
\hline & & & 5 & 4,80 \\
\hline
\end{tabular}


TABELA 4.3 - Determinação da concentração de alumínio por espectrometria UV-vis nas soluções de ácido húmico nas concentrações de 1 ppm e 5 ppm contendo distintas concentrações de íons alumínio.

\begin{tabular}{|c|c|c|c|c|}
\hline $\begin{array}{l}\text { Tipo de } \\
\text { Radiação }\end{array}$ & $\begin{array}{c}\text { Dose absorvida } \\
(\mathrm{kGy}) / \text { Taxa de } \\
\text { dose }(\mathrm{kGy} / \mathrm{s})\end{array}$ & $\begin{array}{l}\text { Concentração de } \\
\text { ácido húmico } \\
\text { (ppm) }\end{array}$ & $\begin{array}{c}\text { Concentração de } \\
\text { alumínio } \\
(\mathrm{ppm})\end{array}$ & $\begin{array}{c}\text { Resultado } \\
\text { Analítico por } \\
\text { Espectrofotometria } \\
\text { UV-vis (ppm) }\end{array}$ \\
\hline \multirow[t]{4}{*}{ Não Irradiado } & \multirow{4}{*}{0} & \multirow{2}{*}{1} & 0,5 & 0,44 \\
\hline & & & 5 & 5,18 \\
\hline & & \multirow{2}{*}{5} & 0,1 & 0,10 \\
\hline & & & 5 & 5,08 \\
\hline \multirow{4}{*}{$\begin{array}{l}\text { Feixe de } \\
\text { Elétrons }\end{array}$} & \multirow{4}{*}{$5 / 2,2$} & \multirow{4}{*}{1} & 2,5 & 1,98 \\
\hline & & & 5 & 5,42 \\
\hline & & & 2,5 & 1,90 \\
\hline & & & 5 & 5,14 \\
\hline
\end{tabular}




\subsection{Conclusões}

- Verificou-se que a degradação das soluções de ácido húmico a partir do processo radiolítico forma carbono inorgânico (mineralização);

- O processo de irradiação aplicado na degradação do AH é mais efetivo em baixas taxa de dose e dose absorvida principalmente quando as soluções apresentam baixas concentrações de ácido húmico;

- O efeito da presença de aditivos no processo de irradiação traz respostas distintas: o uso dos ácidos nítrico e sulfúrico pode provocar aumento do COT quando o processo ocorre em valores altos de dose e em soluções com grande concentração de $\mathrm{AH}$; com o peróxido de hidrogênio há uma efetivação do processo de degradação do ácido húmico principalmente em baixas doses e concentração de AH;

- Os processos de irradiação descomplexam e/ou degradam as soluções de $\mathrm{AH}$ complexadas aos íons $\mathrm{Al}^{3+}$ - a efetividade depende do tipo de processo e dos valores da taxa de dose e da dose absorvida;

- As técnicas de ICP-OES e UV-vis são técnicas quantitativas suficientes para determinar a espécie química alumínio mesmo estando complexada ao ácido húmico, não sendo necessária a mineralização deste tipo de solução. 


\section{REFERÊNCIAS BIBLIOGRÁFICAS}

AIKEN, G.R., MCKNIGHT, D.M., WERSHAW, E.L., MACCARTHY, P. An introduction to humic acid substances in soil, sediment and water. In AIKEN, G.R. (Ed.) Humic substances in soil, sediment and water: Geochemistry, isolation and characterization. Wiley, 1985.

AMERICAN WATER WORKS ASSOCIATION. Water quality and treatment: a handbook of community water supplies. AWWA. 4. ed., 270p, 1990.

ARRUDA, M. A. Z., SANTELli, R. E. Mecanização no Preparo de Amostras por Microondas: O Estado da Arte. Química Nova, v.. 20 (6), p. 638-643, 1997.

BAZANTE-YAMAGUISHI, R.; GERALDO, A.B.C.; MANZOLI, J.E., Radiolytic Degradation of Humic Acid: an alternative to complement the chemical test of Water resources. In: RadTech UV/EB, Chicago, 2012. Disponível em: $<\underline{\text { http://www.radtech2012.com/conference.html }>}$

BISPO, M.S.; BOA MORTE, E.L.; KORN, M.G.A; TEIXEIRA, L.S.G; KORN, M.; COSTA, A.C.S. Determination of $\mathrm{Pb}$ in river water samples by inductively coupled plasma optical emission spectrometry after ultrasound-assisted co-precipitation with manganese dioxide. Spectrocim. Acta Part B. v. 60, p. 653, 2005.

BLUDENKO, A.V., ZHESTKOVA, T.P., ZHUKOVA, T.N., PONOMAREV, A.V. Radiation-chemical transformations of humic acid in aqueous solutions. High energy chemistry, v. 40, p.370-374, 2006.

BURBA, P. \& BERGH, J.V.D. transformations of metal species in ageing humic hydrocolloids studied by competitive ligand and metal exchange. Anal. Bioanal Chem v.378, p.1637-1643, 2004.

BURROWS, H.D., CANLE, L.M., SANTABALLA, J.A., STEENKEN, S. Reaction pathways and mechanisms of photodegradation of pesticides (Invited review). Journal Photochem. Photobiol. B: Biol. v, 67, p.71-108, 2002.

CAMPOS, S.X., BERNARDO, L.; VIEIRA, E.M.. Influência das características das substâncias húmicas na eficiência da coagulação com sulfato de alumínio. Eng. sanit. ambient.v.10(3 ), p. 194-199, 2005.

ENVIRONMENTAL WORKING GROUP. Treatment contaminants: toxic trash in drinking water. Washington, DC: EWG (202), p. 667-6982, 2013. Disponível em: $<$ http://static.ewg.org/reports/2013/water_filters/2012 tap water_report8b.pdf $>$

FERNANDES, A.N.; GIACOMELLI, C.; GIOVANELA, M.; VAZ, D. O.; SZPOGANICZA, B.; SIERRA, M. M. D. Potentiometric Acidity Determination in Humic Substances Influenced by Different Analytical Procedures, Journal Brazilian Chemistry Soc., v.. 20(9), p. 1715-1723, 2009. 
GETOFF, N. Advancements of radiation induced degradation of pollutants in drinking and waste water. Appl. Radiat. Isot. 40, 585-594, 1989.

GOLDSTONE, J.V., PULlin, M.J., BERTILSSON, S., VOELKER, B.M. Reactions of Hydroxil radical with humic substances: bleaching, mineraliazation and production of bioavailable carbon substrates, Environ. Sci. Technol., v. 36, p. 364-372, 2002.

GOUVEIA, S.E.M. \& PESSENDA, L.C.R. Datação da fração húmica da matéria orgânica no solo e sua comparação com idades ${ }^{14} \mathrm{C}$ de carvões fósseis. Química Nova, v.(6)22, p., 1999.

HUBER, M. K. Bottled Water: The Risks to Our Health, Our Environment, and Our Wallets. School of Public and Environmental Affairs Honors Thesis. v. 499 . 46p., 2010. Disponível em: <http://www.indiana.edu/ spea/pubs/undergrad-honors/volume5/huber_marguerite.pdf $>$ Acesso em: 04 abr. 12.

JONES, M.N.; BRYAN, N.D. Colloidal properties of humic substances. Advances in Colloid and Interface Science, v. 78, pp. 1-48, 1998.

KINGSTON, H.M., JASSIE, L.B. (Ed.). Introduction to Microwave Sample Preparation - Theory and Practice. ACS Professional Reference Book. Washington, 263p., 1988.

KNAPP, G.; MAICHIN, B.; BAUMGARTNER, U.; Atomic Spectroscopy. 19, 220, 1998.

KNOLL, G. F. Radiation Detection and Measurement. 2a ed., John Wiley \& Sons, New York, p.60, 1989.

KURUCZ, C.N., WAITE, T.D., COOPER, W.J.,NICKELSEN, M.G. High energy electron beam irradiation of water, wastewater and sludge. In: Lewis, J., Becker, M. (Eds), advances in Nuclear Science and Technology, Plenum press, New York, v. 22, pp. 1-43, 1991.

LISHTVAN, I.I., KRUGLITSKII, N.N., and TRETINNIK, V.YU., Fiziko-khimicheskaya mekhanika guminovykh veshchestv. Physicochermical Mechanics of Humic Substances, Minsk: Nauka I Tekhnika, p., 1976.

MACEDO, J.A.B; ANDRADE, N.J.; ARAÚJO, J.M.A.; CHAVES, JB.P; SILVA, M.T.C; JORDÃO, C.P. Cloraminas orgânicas uma solução para evitar a formação de trihalometanos nos processo de desinfecção de águas para abastecimento pública. Revista Higiene Alimentar, v.15(90-91), p.93-103, 2001.

MACHAT, J.; OTRUBA, V.; KANICKY, V. Journal Anal. Atomic Spectroscopym. 17, 1096, 2002.

MAHAN, B.H. Química um Curso Universitário, 2ª . ed., Ed. Edgard Blücher Ltda., São Paulo, pp.296, 1985. 
MANO, E.B., Introdução a Polímeros, $5^{\text {a }}$. Reimpressão, Ed. Edgard Blücher, São Paulo, pp.58, 1994.

MATUSIEWICZ, H.\& STANISZ, E. characteristics of a novel UV-TiO2- microwave integrated irradiation device in decomposition processes. Microchemical journal 86 9-16, 2007.

MCNEAL, T.P., HOLLIFIELD, H.C., DIACHENCK, G.W. Survey of trihalomethanes and other volatile chemical contaminants in processed food by purge-and-trap capillary gas chromatography with mass selective detection. Journal of AOAC International, v.78, n.2, p.391-397, 1995.

MELNICK, R.L. NTP technical report on the toxicology and carcinogenesis studies of tribromomethane (bromoform) (CAS No. 75-25-2) in F344/N rats and B6C3F! mice (gavage studies). NTP TechnicalReport Series, no. 350. US Department of Health and Human Services, Research Triangle Park, NC, USA. p. 1989.

MOHAMED, K.A., BASFAR, A.A., AL-KAHTANI, H.A., AL-HAMAD, K.S. Radiolytic degradation of malathion and lindane in aqueous solutions. Radiation physics and chemistry v.78, p. 994-1000, 2009.

MORRIS, R.D., AUDET, A.M., ANGELILlO, I.F., CHALMERS, T.C., MOSTELLER. F. Chlorination, chlorination by-products, and cancer: a meta-analysis. Am J Public Health. v. 82(7), p.955-963, 1992.

MORRISON, R.T. \& BOYD, R.T. Química Orgânica, 8ª Ed., Fundação Calouste Gulbenkian, Lisboa, pp.412-414, 1983.

POZEBON, D.; MARTINS, P. Marine sediment analysis using inductively coupled plasma optical emission spectrometry. Atomic Spectroscopy, v. 23, n.4, p. 111-118, 2002.

RITTMANN, D. Can you have cake and eat it too with chlorine dioxide? Water/Engineering \& Management, v.4, p.30-35, 1997.

SCHULTEN, H.R. \& SCHNITZER, M. Chemical model structure for soil organic matter and soils. Soil Science, Baltimore, J. v.162, p.115-130, 1997.

SERIESI, N., CHEN, Y, SHNITZER, M. The electron and $\gamma$-irradiation of humic substances. , Fuel, v. 56 (2), p. 171-176, 1977.

SILVA FILHO, A.V.; SILVA, M.I.V. Importância das Substâncias Húmicas para a Agricultura. Simpósio Nacional sobre as Culturas do Inhame e do Taro, 2., 2002. João Pessoa, PB. Anais... João Pessoa, PB: EMEPA-PB, v. 2, 234 p. 2002. Disponível em: $<$ http://www.emepa.org.br/anais/volume2/av209.pdf $>$ Acesso em: 22 mai.12.

SNOEYINK, V.L; JENKINS, D. Water chemistry. Universidade de Michigan Wiley, 463p., 1980. 
SOUZA, C.R.; GUIMARÃES,E., MANGRICH, A.S.; MERCÊ, A.L.R. Estudo da complexação de ácido fúlvico extraído de solos de plantio direto com íons $\mathrm{Ni}(\mathrm{II})$ e $\mathrm{Pb}(\mathrm{II})$ por titulação potenciométrica. Sociedade Brasileira de Química (SBQ) In: 29a Reunião Anual da Sociedade Brasileira de Química. 2006. Disponivel em:

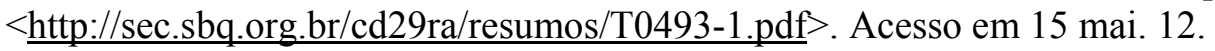

TABATA, Y, ITO, Y., TAGAWA, S. CRC Handbook of Radiation Chemistry, CRC Press Inc., Boca Raton, pp. 70-71, 1991.

TOLEDANO, M.B.; NIEUWENHUIJSEN, M.J.; BEST, N. WHITAKER, H.; HAMBLY, P. HOOGH, C.de.; FAWELL, J. JARUP, L.; ELLIOTT, P. relation of trihalomethane concentrations in public water supplies to stillbirth an borth weight in three water regions in England. Environmental Health Perspectives. v.113(2), p. 225-232, 2005.

TUNDISI \& MATSUMURA-TUNDISI. The Lobo-Broa ecosystem research. In: J. G. Tundisi, C. E. M. Bicudo \& T. Matsumura- Tundisi (eds.), Limnology in Brazil, ABC/SBL Publisher, Rio de Janeiro, 376p, 1995.

TWYMAN, R. M. Wet Digestion / Sample Dissolution for Elemental Analysis. In: P. WORSFOLD, A. TOWNSHEND \& C. POOLE (eds). Encyclopedia of Analytical Science, vol. 8, 2. ed. New York: Ed. Elsevier Academic Press, 2005. UYGUNER, C. S. \& BEKBOLET, M. Evaluation of humic acid photocatalytic degradation by UV-vis and fluorescence spectroscopy. Catalysis Today. v.101, pp. 267-274, 2005.

UYGUNER, C.S. \& BEKBOLET, M. Evaluation of humic acid photocatalytic degradation by UV-vis and fluorescence spectroscopy. Catalysis Today v. 101, p. 267-274, 2005.

VELLOSO, A.C.X.; SANTOS, G.A. \& RAMOS, D.P. Capacidade de troca de cátions e adsorção de fosfato de solos sob vegetação de cerrado do Amapá. Pesquisa Agropecuária Brasileira, Brasília, v.17, p.27-32, 1982.

VOGEL, A.I. Vogel's Textbook of Quantitative Chemical Analysis, 5th ed., Longman Scientific \& Technical, Essex, England, 1989.

WANG, G.S., HSIEH, S.T., HONG, C.S. Destruction of humic acid in water by UV lightcatalyzed oxidation with hydrogen peroxide. Water Resource. v. 34, n. 15, pp. 3882-3887, 2000 .

WASILEWSKA, M.; GOESSLER, W.; ZISCHKA, M.; MAICHIN, B.; KNAPP, G. Journal Anal. Atomic Spectroscopy. v.17, p.1121, 2002. 


\section{RADIAÇÃO IONIZANTE NA OTIMIZAÇÃO DO DIAGNÓSTICO DE ALUMÍNIO EM AMOSTRAS DE ÁGUA POTÁVEL}

\subsection{Introdução}

A quantidade excessiva de alumínio encontrada em água destinada ao consumo tem levado pesquisadores a investigar as causas e os efeitos negativos desse metal na saúde do homem (KLEN, 2005; MEYER-BARON et al., 2007; PRIEST \& O'DONNELL, 2013).

Pesquisas realizadas por Tomijenovic (2011) evidenciam que o alumínio consumido em grandes quantidades é tóxico, causando doenças crônicas, como a doença de Alzheimer, devido o seu acúmulo nos tecidos e nas células neurológicas, expondo o organismo ao processo de bioacumulação do metal. Evidências mostram que este metal também provoca a seborréia, alopécia, irritabilidade, deslocamento do cálcio e magnésio dos ossos levando a uma osteoporose (PASCALICCHIO, 2002; GUPTA et al., 2005).

A presença do alumínio em águas pode ter origem em duas fontes principais: i) mineralização natural e de atividades de microorganismos, conduzindo a baixos níveis em águas subterrâneas e superficiais (abaixo de $0,1 \mathrm{mg} / \mathrm{l}$ ); ii) intervenção direta de atividade antropogênica, tais como emissão de fontes difusas de efluentes industriais, principalmente de deposição ácida causada pelo dióxido de enxofre, óxidos de nitrogênio e amoníaco (VANLOOT et al., 2007), onde sua biodisponibilidade é observada se o $\mathrm{pH}$ do meio for abaixo de 4,2, o que garante a sua mobilidade. Entretanto, sua complexação se dá em pH maior que 2,5 (GIROUX et al., 2004); outra forma direta é o sulfato de alumínio $\left(\mathrm{Al}_{2}\left(\mathrm{SO}_{4}\right)_{3}\right)$ que é muito utilizado no processo de tratamento de águas de mananciais pelas companhias governamentais de saneamento básico, já que em estado coloidal essa substância promove a floculação de impurezas em suspensão como a matéria orgânica (formação de complexos). Entretanto, o seu uso contínuo nesse processo pode acarretar o aumento do teor desse metal na água para consumo.

A resolução 396/08 do CONAMA contempla a classificação das águas subterrâneas e dá diretrizes ambientais para o seu enquadramento, prevenção e controle, além dos valores de intervenção para os diferentes contaminantes. De acordo com o relatório da qualidade das águas subterrâneas da CETESB, não há poços da região da represa Billings incluídos no plano de monitoramento (CETESB, 2010). 
O projeto da Associação de Turismo da Ilha do Bororé (ATIBORÉ, 2012), financiado pelo Fundo Especial do Meio Ambiente (FEMA), pertencente à Secretaria Municipal do Verde e Meio Ambiente (SVMA), foi pioneiro na realização do mapeamento georreferenciado de poços utilizados por famílias de pescadores da Ilha do Bororé (bairro pertencente ao complexo Billings) e no fornecimento de informações sobre a qualidade dessas águas à população regional e externa (visitantes). Nesse projeto foram estudados metais tóxicos em dez poços da região onde a água era classificada informalmente pelos moradores como "potável”. Os metais avaliados foram: arsênio, chumbo, cromo, cadmio, bário, mercúrio, cobre e zinco, cujos resultados mostraram que os seus teores estavam abaixo do VMP (portaria 2914/11 do MS), entretanto, outros metais analisados tais como alumínio, manganês e o ferro apresentaram valores acima do VMP como mostram as TAB.5.1 a TAB. 5.3. A avaliação microbiológica da água mostrou que cerca de $90 \%$ dos poços estão contaminados por E. coli e Coliformes Totais. Embora esse trabalho tenha sido inédito com relação às informações sobre a qualidade da água desses poços, diagnósticos qualitativos e quantitativos da fração de substâncias orgânicas, incluindo agrotóxicos e herbicidas, precisam ser realizados, já que a região é uma área rural em que a atividade de plantio ainda predomina.

TABELA 5.1.: Resultados do alumínio total em água subterrânea - período 2011-12 (adaptado ATIBORÉ, 2012).

\begin{tabular}{|c|c|c|c|c|c|c|}
\hline \multicolumn{7}{|c|}{ Alumínio (mg/l) } \\
\hline Coletas & 1 & 2 & 3 & 4 & 5 & 6 \\
\hline \multicolumn{7}{|l|}{ Poços } \\
\hline P1 & 5,929 & 0,699 & 0,643 & 0,560 & 1,010 & 0,360 \\
\hline P2 & $\mathbf{0 , 8 0 3}$ & 0,328 & 0,723 & $\mathbf{0 , 3 5 0}$ & 0,370 & 0,240 \\
\hline P3 & $<\mathrm{LQ}^{* * *}$ & $<\mathrm{LQ}$ & 0,639 & $<\mathrm{LQ}$ & 0,390 & 0,390 \\
\hline P4 & 0,088 & 0,725 & 0,421 & 0,070 & $<\mathrm{LQ}$ & 0,080 \\
\hline P5 & 1,452 & $\mathbf{0 , 8 0 1}$ & 2,621 & 1,390 & 0,760 & $\mathbf{0 , 5 8 0}$ \\
\hline P6 & $<\mathrm{LQ}$ & $\mathbf{0 , 5 3 0}$ & 0,122 & NA* & NA* & NA* \\
\hline P7 & 0,149 & 0,013 & 0,174 & 0,190 & $<\mathrm{LQ}^{* * *}$ & $<\mathrm{LQ}^{* * *}$ \\
\hline P8 & 0,620 & 0,944 & 1,819 & NA* & 0,630 & 1,000 \\
\hline P9 & 5,220 & 0,111 & 1,550 & 2,460 & 1,740 & 1,680 \\
\hline P10 & 0,342 & 0,470 & 1,997 & 1,100 & 0,700 & $\mathbf{0 , 3 8 0}$ \\
\hline VMP (mg/L)** & \multicolumn{6}{|c|}{0,2} \\
\hline
\end{tabular}


TABELA 5.2. Resultados do manganês total em água subterrânea - período 2011-12 (adaptado ATIBORÉ, 2012).

\begin{tabular}{l|cccccc}
\hline \multicolumn{7}{c}{ Manganês (mg/l) } \\
\hline \multicolumn{1}{c}{ Coletas/bimestral } & $\mathbf{1}$ & $\mathbf{2}$ & $\mathbf{3}$ & $\mathbf{4}$ & $\mathbf{5}$ & $\mathbf{6}$ \\
\hline Poços/amostras & & & & & & \\
P1 & $\mathbf{0 , 2 8 3}$ & 0,035 & $<\mathrm{LQ}$ & 0,095 & 0,027 & 0,012 \\
P2 & $<\mathrm{LQ}$ & 0,054 & $\mathbf{0 , 1 1 6}$ & 0,038 & 0,037 & 0,018 \\
P3 & $<\mathrm{LQ}$ & $<\mathrm{LQ}$ & 0,082 & 0,009 & 0,093 & 0,053 \\
P4 & $<\mathrm{LQ}$ & 0,050 & 0,026 & 0,030 & 0,023 & 0,010 \\
P5 & $<\mathrm{LQ}$ & $<\mathrm{LQ}$ & $\mathbf{0 , 1 1 2}$ & 0,032 & 0,026 & 0,010 \\
P6 & $<\mathrm{LQ}$ & $<\mathrm{LQ}$ & 0,022 & $\mathrm{NA} *$ & $\mathrm{NA}$ & $\mathrm{N} \mathrm{A}^{*}$ \\
P7 & $<\mathrm{LQ}$ & $<\mathrm{LQ}$ & $\mathbf{0 , 1 6 6}$ & 0,056 & 0,032 & 0,007 \\
P8 & $<\mathrm{LQ}$ & 0,085 & $\mathbf{0 , 1 9 5}$ & $\mathrm{NA}$ & 0,047 & 0,041 \\
P9 & $\mathbf{0 , 3 2 2}$ & $<\mathrm{LQ}$ & $<\mathrm{LQ}$ & $\mathbf{0 , 1 2 4}$ & 0,082 & 0,085 \\
P10 & $<\mathrm{LQ}$ & 0,055 & $\mathbf{0 , 1 7 2}$ & 0,060 & 0,055 & 0,014 \\
\hline VMP (mg/L)** & & & 0,1 & & & \\
\hline
\end{tabular}

* Não aplicado; ** Valor Máximo Permitido segundo a portaria 2914/11 MS;*** Limite de quantificação: Mg=0,005mg/l. Em negrito os resultados acima do VMP 
TABELA 5.3. Resultados do ferro total em água subterrânea - período 2011-12 (adaptado ATIBORÉ, 2012).

\begin{tabular}{|c|c|c|c|c|c|c|}
\hline \multicolumn{7}{|c|}{ Ferro (mg/l) } \\
\hline Coletas & 1 & 2 & 3 & 4 & 5 & 6 \\
\hline \multicolumn{7}{|l|}{ Poços } \\
\hline P1 & 0,205 & 0,182 & 0,055 & $<\mathrm{LQ}$ & $<\mathrm{LQ}$ & $<\mathrm{LQ}$ \\
\hline $\mathbf{P 2}$ & 0,586 & 0,053 & $<\mathrm{LQ}$ & $<\mathrm{LQ}$ & $<\mathrm{LQ}$ & $<\mathrm{LQ}$ \\
\hline $\mathbf{P 3}$ & $<\mathrm{LQ}^{* * *}$ & $<\mathrm{LQ}$ & 0,610 & 0,231 & $<\mathrm{LQ}$ & $<\mathrm{LQ}$ \\
\hline P4 & $<\mathrm{LQ}$ & 1,750 & 0,139 & $<\mathrm{LQ}$ & $<\mathrm{LQ}$ & $<\mathrm{LQ}$ \\
\hline P5 & 0,707 & 0,062 & 0,168 & $<\mathrm{LQ}$ & $<\mathrm{LQ}$ & 0,104 \\
\hline P6 & $<\mathrm{LQ}$ & $\mathbf{0 , 8 5 8}$ & 0,152 & NA & $<\mathrm{LQ}$ & $<\mathrm{LQ}$ \\
\hline P7 & $<\mathrm{LQ}$ & $<\mathrm{LQ}$ & 0,042 & 0,818 & $<\mathrm{LQ}$ & $<\mathrm{LQ}$ \\
\hline P8 & $<\mathrm{LQ}$ & 0,093 & 0,013 & $\mathrm{NA}^{*}$ & $<\mathrm{LQ}$ & $<\mathrm{LQ}$ \\
\hline P9 & $<\mathrm{LQ}$ & $<\mathrm{LQ}$ & 0,130 & 1,323 & $<\mathrm{LQ}$ & $<\mathrm{LQ}$ \\
\hline P10 & 0,026 & 0,203 & 0,045 & $<\mathrm{LQ}$ & $<\mathrm{LQ}$ & $<\mathrm{LQ}$ \\
\hline VMP $(\mathbf{m g} / \mathbf{L})^{* *}$ & \multicolumn{6}{|c|}{0,3} \\
\hline
\end{tabular}

De acordo com o Instituto de Estudos Avançados da Universidade de São Paulo (IEA), desde o início de 2003, uma equipe internacional de pesquisadores está desenvolvendo uma nova ferramenta para auxiliar na negociação de conflitos sobre água e ocupação do solo na Bacia do Alto Tietê - o projeto NEGOWAT - onde são retratados três problemas centrais no gerenciamento da UGRHI 6: 1) melhoria da qualidade da água e proteção dos recursos, especialmente nas nascentes; 2) adequação dos recursos hídricos versus a demanda num contexto de crescimento populacional e aumento das tensões; 3 ) gerenciamento das inundações. O relatório técnico sobre conflitos pela água em perímetros urbanos da IRC (Internaticonal Water and Sanitation Center) aponta que somente com processos altamente sofisticados e extremamente caros de tratamento de água atribuido às companhias de abastecimento de água potável é que a cidade vai garantir a remoção de diversas fontes de poluição nos reservatórios (IRC, 2007).

A portaria 2914/11 relata que "toda água destinada ao consumo humano, distribuída coletivamente por meio de sistema ou solução alternativa coletiva de abastecimento de água deve ser objeto de controle e vigilância da qualidade da água" (MS, 2011). 


\subsubsection{O metal alumínio}

O alumínio é um metal que não se encontra livre na natureza e sua principal fonte é a bauxita (SCOTT, 1952; FURMAN, 1962). Sua presença na água pode afetar a qualidade organoléptica e isso depende do $\mathrm{pH}$, da temperatura e da presença dos íons fluoreto, sulfato, além da matéria orgânica. Sua solubilidade é baixa em pH entre 5,5 e 6,0; em locais profundos onde ocorre anaerobiose e pH mais baixo, sua concentração pode tornar-se elevada (CETESB, 2010). A distribuição entre as diferentes espécies do alumínio (processo chamado especiação) é essencial para a compreensão da toxicidade, biodisponibilidade e dos mecanismos de transporte desse elemento químico no ambiente natural.

Para determinar a espécie química alumínio, deve-se conhecer três categorias do metal (CLARKE et al., 1996):

- instável - fracamente ligado e livre (alumínio monomérico, sulfato de alumínio, fluoreto e complexos de hidróxido);

- não instável - monomérica e termodinâmica estáveis (complexos de alumínio com ligantes orgânicos);

- cineticamente inertes e termodinamicamente estáveis (complexos do tipo de material polimérico e colóides).

Nos solos de regiões tropicais, o estudo do complexo entre a matéria orgânica e o alumínio é importante no controle da toxicidade do metal, principalmente quanto à sua dissolução, pois os íons alumínio livres neutralizam a entrada de ácidos provenientes das chuvas. Nesta forma, ele é extremamente tóxico à vegetação e aos animais, pois pode ser escoado para os corpos d'água (MENDONÇA et al.,1991). A toxicidade do alumínio ao ser humano ocorre principalmente pela via oral, sendo as principais fontes, água potável, resíduo nos alimentos, utensílios de cozinha, embalagens, fórmulas antiácidas e antiperspirantes (QUINTAES, 2000). 


\subsection{Objetivos}

- Investigar a contaminação por alumínio, através da aplicação do processo de irradiação ionizante como processo de mineralização das amostras de água provenientes de nascente, poços de captação e água da margem da represa Billings.

- Aplicar o PAMQUÁ® nos resultados obtidos da espécie química alumínio somente nos poços e nascente deste estudo.

\subsection{Materiais e Métodos}

\subsubsection{Metodologia de amostragem}

O estudo foi realizado na região da Ilha do Bororé, um dos braços da represa Billings, pertencente ao subdistrito do Grajaú, município de São Paulo. A seleção dos pontos de amostragens (poços) e sua distribuição seguiram as normas da Agência Ambiental Européia (KOREIMANN et al., 1996 e NIXON et al., 1998). Para este estudo, quatro poços não cadastrados no Departamento de Águas e Energia Elétrica (DAEE), caracterizados como três poços rasos (P1, P8 e P9) e um profundo (P4) foram georeferenciados (ANEXO A) e mapeados (ANEXO B). As amostras foram coletadas a cada bimestre entre agosto/2011 e julho/2012, de modo que o monitoramento abrangesse todas as épocas do ano (épocas secas e úmidas). A TAB. 5.4 mostra as denominações de cada bimestre amostrado.

TABELA 5.4. Denominações de cada bimestre de coleta de amostras

\begin{tabular}{lc}
\hline Bimestre de amostragem & Denominação \\
\hline Agosto-Setembro/2011 & 1 \\
Outubro-Novembro/2011 & 2 \\
Dezembro/2011-Janeiro/2012 & 3 \\
Fevereiro-Março/2012 & 4 \\
Abril-Maio/2012 & 5 \\
Junho-Julho/2012 & 6 \\
\hline
\end{tabular}

A escolha dos quatro poços foi em virtude de serem principais fontes de consumo de água potável pela comunidade pesqueira, são comunitários e apresentarem excesso de alumínio dentre os dez poços estudados durante o projeto ATIBORÉ/FEMA. Porém, neste trabalho não foi construído poços de monitoramento para correlacionar os parâmetros de qualidade dessas águas, entretanto, foi considerado como controle o único 
poço profundo - P4, devido sua conformidade perante os resultados microbiológicos à portabilidade.

Neste trabalho também foram estudados uma nascente da região, a água das margens da represa Billings e o branco de campo ( água destilada).

As amostras foram obtidas com o auxílio de baillers descartáveis para cada ponto (ANEXO C). Em seguida, dois frascos de $250 \mathrm{ml}$ foram identificados. As amostras não foram acidificadas com ácido nítrico, elas foram separadas em filtrada e não filtrada para as respectivas determinações do alumínio: dissolvido e total. O processo de filtração em campo foi realizado com o auxilio de uma bomba manual e um suporte de membrana da Millipore ${ }^{\circledR}$, contendo filtro de celulose 0,45 $\mu \mathrm{m}$ (ANEXO C). Para o branco de campo foi utilizada água destilada que também fora filtrada durante a coleta. Uma ficha de informações diárias de cada ponto foi preenchida durante a amostragem, contendo dados de temperatura ambiente, a ocorrência de chuva no momento da coleta e no dia anterior, além das informações físicas do poço, tais como diâmetro, profundidade e nível d'água (ANEXO A).

$\mathrm{O}$ pH e demais características físico-químicas das águas como: Turbidez (UNT), Sólidos Totais Dissolvidos (STD - mg/L), Condutividade elétrica $(\mu \mathrm{S} / \mathrm{cm})$, Temperaturas da água e do ar $\left({ }^{\circ} \mathrm{C}\right)$ foram medidos através de uma sonda multiparâmetros da marca Hanna, modelo HI9828 e todas as amostras de água foram armazenadas em caixas de isopor com gelo até a chegada ao laboratório químico do Centro de Tecnologia das Radiações (CTR) do IPEN.

As amostras foram analisadas no equipamento de espectrometria de emissão óptica por plasma acoplado indutivamente (ICP-OES modelo Thermo iCAP 6000 laboratório químico ASL Análises Ambientais Ltda, acreditado pelo INMETRO Reg. $\mathrm{n}^{\circ}$. CRL 0267 - método USEPA 6010-C). 


\subsubsection{Metodologia de análise química}

Foi aplicada irradiação gama nas amostras de água para a digestão amostral, partir da fonte Gammacell $\left({ }^{60} \mathrm{Co}\right)$, com taxa de dose máxima de $1,33 \mathrm{kGy} / \mathrm{h}$, nas seguintes doses de absorção: 10 kGy, 20 kGy, 40 kGy e 60 kGy.

As amostras foram colocadas em tubos de ensaio, cujo volume total para as amostras provenientes de cada poço estudado foi de $100 \mathrm{ml} \mathrm{e}$, posteriormente, foram analisadas o COT, de acordo com a metodologia descrita no capítulo 4 e a especiação química do alumínio por ICP-OES. Os resultados foram confrontados com os das amostras não irradiadas. . Esta metodologia também foi aplicada em amostras controle (branco), usando água destilada, para verificação de possíveis interferências vindas de reagentes, do "branco" da coleta e/ou da descontaminação inadequada de recipientes.

\subsubsection{Metodologia de Análise Microbiológica}

Foi aplicado o método 9223-b do Standarnd Methods for the Examination of Water and Wastewater (SMEWW) para analise de Escherichia coli e coliformes totais, respectivamente para todas as amostras, incluindo branco de campo. Os resultados foram expressos em número de organismos por $100 \mathrm{ml}$ de água e comparados ao VMP.

\subsection{Resultados e Discussão}

\subsubsection{Análise físico-químicas: $\mathrm{pH}$}

Sabe-se que o pH (potencial hidrogeniônico) da água é uma medida de equilíbrio ácido-base. Nas águas naturais refere-se ao equilíbrio entre as espécies dióxido de carbono e íons carbonato/bicarbonato (RODRIGUES et al., 2010). O pH não tem impacto como indicador de qualidade da água quando apresentado como resultado isolado, porém em conjunto com outros parâmetros tem importância tanto operacional quanto no poder de decisão sobre a sua qualidade. O monitoramento do $\mathrm{pH}$ nas etapas do tratamento da água para abastecimento auxilia na garantia de clarificação satisfatória da água e na qualidade da sua desinfecção. $\mathrm{O}$ pH da água no sistema de distribuição deve ser controlado para minimizar a corrosão dos dutos de abastecimento para os diversos usos (OMS, 1996; APHA, 1999).

Alterações de $\mathrm{pH}$ são influenciadas pela temperatura ambiente e reações bioquímicas: as atividades fotossintéticas por exemplo reduzem a assimilação de dióxido de carbono e bicarbonatos. A exposição do ser humano a valores extremos desse parâmetro 
( $\mathrm{pH} \leq 4$ ou $\mathrm{pH} \geq 11)$ resulta em irritação dos olhos, pele e membranas mucosas; valores abaixo de 2,5 resultam em danos irreversíveis ao epitélio. Há relatos que soluções com pH entre 10 e 12,5 causam inchamento de fibras de cabelo e sua consequente queda (OMS, 1996). Segundo o Ministério da Saúde, o pH ótimo da água potável deve estar entre 6,5 e 9,5, porém esses valores podem variar dependendo da natureza dos materiais em que a água está em contato e da própria composição da água (MS, 2011).

Neste estudo, os resultados de $\mathrm{pH}$ das amostras de água dos locais investigados (TAB 5.6) mostraram que:

a) as amostras de água dos poços nos locais $\mathrm{P} 1$ e $\mathrm{P} 9$ obtiveram valores de $\mathrm{pH}$ que pouco variaram nas épocas amostradas.Verificou-se valores entre 4,5 e 4,7 no poço P1 e 4,7 e 5,0 no ponto P9;

b) as amostras de água do poço $\mathrm{P} 8$ obtiveram valores de $\mathrm{pH}$ entre 4,4 e 5,7, sendo que esse valor mínimo foi observado em período de estiagem/seca e o valor máximo, em um período chuvoso;

c) as amostras de água do poço $\mathrm{P} 4$ obteve valores de pH entre 5,14 e 6,7, sendo que foi observado o valor máximo em período de estiagem/seca, onde há uma maior concentração de sais (observar os resultados da condutividade elétrica na sequência).

d) as amostras de água da nascente tiveram valores de $\mathrm{pH}$ entre 4,4 e 6,5, sendo que o maior valor foi verificado em um período de estiagem/seco e o menor valor, em uma período chuvoso;

e) as amostras das águas superficiais da represa Billings acusaram valores entre pH 6,7 e pH 9,0, sendo esse valor máximo alcalino registrado no mês de agosto (época seca) e também observou-se o despejo de efluente doméstico

direto nas águas, inserindo depósito de produtos saneantes, como detergentes e outros agentes químicos; em dezembro/janeiro (época úmida) o valor registrado de $\mathrm{pH}$ foi de 7,2.

Sobre esses resultados pode-se afirmar que as águas subterrâneas nos locais amostrados têm características acídicas, diferindo da característica alcalina da água superficial da represa, verificada na maior parte dos períodos amostrados.

\subsubsection{Sólidos totais dissolvidos}

O parâmetro sólidos totais dissolvidos (STD) é usado para quantificar o material dissolvido na água e que pode ser sais inorgânicos, formado principalmente pelos 
íons cálcio, magnésio, sódio, potássio, carbonato, hidrogenocarbonato, cloreto, sulfato e nitrato, além de matéria orgânica.

A presença de sólidos dissolvidos na água pode afectar o seu sabor. A palatabilidade de água foi classificado pela WHO (1996) em relação ao seu nível de STD como se segue: excelente, inferior a $300 \mathrm{mg} / \mathrm{l}$; boa, de 300 a $600 \mathrm{mg} / \mathrm{l}$; justo, entre 600 e $900 \mathrm{mg} / \mathrm{l}$; pobre, entre 900 e $1200 \mathrm{mg} / \mathrm{l}$, e inaceitável, superior a $1200 \mathrm{mg} / \mathrm{l}$. Concentrações extremamente baixas de TDS também podem ser classificadas como inaceitável por ser insípida.

Os resultados de STD mostrados na TAB. 5.6 informam que o STD pouco varia nas águas provenientes da nascente e nas águas superficiais da represa, sendo os valores mínimo máximo respectivamente de 14 a 23 ppm e 80 a 90 ppm, sugerindo que a dinâmica de material dissolvido não é influenciada pela sazonalidade.

Nos poços os resultados mínimo e máximo variaram como segue: P1: de 25 a 285 ppm, P4: 9 a 49 ppm, P8: de 44 a 82 ppm e P9: de 89 a 230 ppm. No caso do valor máximo em $\mathrm{P} 1$, o resultado pode estar relacionado com a ocorrência de precipitação prévia à amostragem e que deve ter sido um resultado isolado, já que nos outros períodos amostrados o teor de STD tem uma frequência interessante: em dezembro/janeiro (período chuvoso/úmido) o teor de STD é de 89 ppm, porém no período seguinte (fevereiro/março), que não se caracteriza por chuvas mais frequentes, o teor de STD cai para $25 \mathrm{ppm}$. É observado que o poço possui uma arquitetura antiga e sua construção não é observada vedação e proteção nos casos de chuvas fortes. Comportamento semelhante é observado em P8: em dezembro/janeiro observa-se o valor de STD em 82 ppm e no período seguinte, o valor de STD cai para 44 ppm. Esses resultados sugerem com a incidência de chuvas há maior arraste de material para a água desses poços e na época mais seca, a quantidade de material dissolvido na água diminui. Sendo assim, o teor de STD varia com a sazonalidade. A arquitura do poço P8 também é antiga, não tendo vedação apropriada para o solo. O poço P4, apresentou um valor de STD mais baixo comparado com todos os poços. Ele é o único poço profundo (55 metros) e apresenta sistema de bombeamento por injeção de ar. Somente no período chuvoso apresentou a maior concentração de STD.

O poço P9 tem comportamento inverso: observa-se 99,6 ppm de STD no período de dezembro/janeiro, porém, no período seguinte esse valor aumenta para 230 ppm; aqui, analisando os valores reportados para os outros períodos, observa-se que os períodos secos de inverno (agosto-setembro/2011 e junho-julho/2011) também possuem STD mais alto, o que pode sugerir uma dinâmica de dissolução de sólidos distinta - a 
maior umidade da época favorece a diluição dos sólidos enquanto que na época seca, a presença de sólidos é maior. Observa-se também que a distância do poço P9 às margens da represa Billings é muito próxima (ANEXO B).

\subsubsection{Condutividade elétrica}

Os resultados de condutividade elétrica estão relacionados à dispersão dos íons no meio: quanto maior a quantidade de íons dispersos, maior é o valor desse parâmetro. Esses íons são cátions e ânions provenientes de sais inorgânicos, sendo os mais frequentes: cálcio, magnésio, sódio, potássio, carbonato, hidrogenocarbonato, cloreto, sulfato e nitrato

Os resultados desse parâmetro mostrados na TAB 5.6 convergem para as observações discutidas no item anterior (5.3.2). Esse parâmetro medido nas águas da represa Billings mostram que não há variação significativa, sendo os valores mínimos e máximos respectivamente 157 e $171 \mu \mathrm{S} / \mathrm{cm}$, sendo que justamente este valor máximo observado no período de dezembro/janeiro (período chuvoso) e o valor mínimo, no período seguinte, sugerindo que a ocorrência de maior umidade arrasta os sais do solo, promovendo maior concentração nestas nas águas superficiais.

No caso da nascente, P1 e P8 o comportamento guarda semelhanças tanto com a descrita no item 5.3.2 para a avaliação de STD como para este mesmo parâmetro descrito acima para as águas superficiais da represa Billings. Os valores mínimos e máximos nas amostras foram os seguintes: a) nascente: 15 e $121 \mu \mathrm{S} / \mathrm{cm}$; b) P1: 49 e 569 $\mu \mathrm{S} / \mathrm{cm}$, c) P4: 17 e $97 \mu \mathrm{S} / \mathrm{cm}$ e d) P8: 88 e $163 \mu \mathrm{S} / \mathrm{cm}$. No caso da nascente, o valor máximo refere-se ao período de dezembro/janeiro (período chuvoso) e o valor mínimo está muito próximo ao valor de $20 \mu \mathrm{S} / \mathrm{cm}$ e que corresponde ao período de amostragem seguinte (fevereiro/março). No caso do $\mathrm{P} 1$, novamente o valor máximo corresponde ao mesmo período observado para o valor máximo de STD, mas no período de dezembro/janeiro é também alto $(173 \mu \mathrm{S} / \mathrm{cm})$ e cai para o valor mínimo mencionado no período seguinte. Com relação ao $\mathrm{P} 8$, o valor máximo refere-se à epoca úmica (dezembro/janeiro) e o valor mínimo refere-se ao período seguinte e as mesmas considerações feitas em 5.4.2 cabem na explicação dos valores desse parâmetro nesses poços. O valor mínimo da condutividade do poço P4 é semelhante a nascente, ambos os pontos estão próximos, elevando seu valor no período chuvoso.

O poço P9 também tem um comportamento distinto dos demais poços no parâmetro condutividade elétrica. Os valores extremos obtidos nos períodos amostrados foram: 199 e $350 \mu \mathrm{S} / \mathrm{cm}$ e referem-se respectivamente ao período chuvoso 
(dezembro/janeiro) e o período seguinte (fevereiro/março), sugerindo que a umidade do período mencionado tem o efeito de dispersar os sais iônicos presentes na água desse poço e em períodos mais secos a concentração salina é naturalmente alta; valores de condutividade altos também são observados nos períodos de agosto/setembro: $285 \mu \mathrm{S} / \mathrm{cm}$ e em junho/julho: $266 \mu \mathrm{S} / \mathrm{cm}$.

\subsubsection{Turbidez}

Este parâmetro está relacionado com a medida da dificuldade de um feixe de luz atravessar uma quantidade padronizada de amostra. Esse tipo de medida é comparativa com o espalhamento de luz de igual intensidade quando passa por uma solução padrão. A amostra que tem alta turbidez pode conter alto teor de de matéria sólida em suspensão, como silte, argila, sílica e colódes e também matéria orgânica e inorgânica finamente dividida, organismos microscópicos e algas. Dessa forma, está associada à condutividade elétrica e também a grande quantidade de fitoplâncton (MERCANTE et al., 2011).

As causas do aumento da turbidez em águas superficiais deve-se a atividades antropogênicas (mineração, esgoto proveniente de indústrias específicas e esgoto domiciliar) e também pode estar relacionado à estabilidade do solo (presença ou ausência de mata ciliar). O material que causa a turbidez precipita-se vagarosamente e pode ter partículas com tamanhos que variam de poucos micrometros a $0,01 \mu \mathrm{m}$. Águas superficiais em geral apresentam baixa turbidez, as de classe 2, de acordo com a resolução 367/05 do CONAMA é até 100 NTU, porém valores elevados estão relacionados à ocorrência de ventos e ondas que podem revolver sedimentos, além disso, chuvas fortes provocam o aumento da turbidez devido ao arraste dos sedimentos das margens pelas enxurradas. No entanto, águas subterrâneas tem valores de turbidez abaixo de 1 NTU.

Os resultados de turbidez para as amostras de água da represa Billings tiveram o valor mínimo de cerca de 6 NTU no período de estiagem/seca (abril/maio) e valor máximo de cerca de 32 NTU (junho/julho); no período chuvoso (dezembro/janeiro) esse valor ficou em torno de $12 \mathrm{NTU}$, que foi baixo se comparado aos períodos posterior e anterior. As causas da ocorrência do valor máximo podem ser diversas, uma vez que a qualidade de água da represa é influenciada por atividades antropogênicas quanto pelos efeitos climáticos.

Quanto às águas dos poços analisados, pode-se observar que no caso da nascente, o valor da turbidez está em geral abaixo de 1, o que mostra a boa qualidade das amostras provenientes desse local quanto à turbidez. Já os poços P1 e P8 apresentam 
valores máximos de cerca de 3 e 15 respectivamente nas épocas secas (agosto/setembro e junho/julho), sugerindo que nessa época pode ocorre maior contato da água com o lodo do leito apesar de serem os poços mais profundos ou ainda algum tipo de contaminação externa; na época úmida (dezembro/janeiro), os valores são mais baixos (cerca de 1,4 e 5 respectivamente), o que sugere o efeito de arraste de material durante essa época. Como foi mensionado, esse poços não possuem proteção, vedação no solo e cercamento que poderia evitar o contato com excretas de animais, animais mortos, folhagens secas, efluentes domésticos de moradias à montante e chuvas intensas. Nos outros períodos amostrados os valores de turbidez ficam em torno de 1 . O poço P4 apresentou a maior turbidez (43 NTU) no período chuvoso (dezembro/janeiro), entretanto foi um resultado isolado, já que durante as demais coletas o valor ficou entre 1 a 3 NTU.

O poço P9 revela novamente comportamento distinto dos P1 e P8: nas épocas secas o valor de turbidez é cerca de 2 (agosto/setembro e junho/julho) e na época úmida, esse valor aumenta para cerca de 7, sugerindo que as águas desse poço estão sugeitas ao arraste de material proveniente do intemperismo, além da proximidade com sua fossa asséptica $(<30$ metros).

\subsubsection{Temperatura}

A amplitude térmica de águas subterrâneas é pequena; isto significa que a temperatura destas não é influenciada pelas mudanças de temperatura atmosférica, a menos que o aqüífero freático seja pouco profundo. Estando situado em grandes profundidades, a temperatura do aqüífero é influenciada pelo grau geotérmico local, em média $1{ }^{\circ} \mathrm{C}$ a cada 30 m. Em regiões vulcânicas ou de falhamentos profundos as águas são aquecidas, dando origem às fontes termais. Segundo Mercante et al., (2011) em meio aquático, as variações de temperatura costumam ser brandas, visto que o calor específico do meio é muito alto.

Segundo os resultados das TAB. 5.5, observa-se que as medidas de temperatura ambiente máxima nos períodos amostrados foram desde 13 a $37{ }^{\circ} \mathrm{C}$. Comparando com a temperatura das águas de poços rasos e profundo, obtemos uma temperatura que abrange uma maior escala de 12 a $24{ }^{\circ} \mathrm{C}$ em poços rasos e uma menor escala de 18 a $22^{\circ} \mathrm{C}$ em poço profundo (P4). Já na nascente e na represa, os valores são semelhante ao do poço profundo (P4) de 19 a $23{ }^{\circ} \mathrm{C}$ e 18 a $21{ }^{\circ} \mathrm{C}$. 
TABELA 5.5. Comparação da temperatura do ambiente e da água dos poços, nascente e represa.

\begin{tabular}{|c|c|c|c|c|c|c|c|c|c|c|c|c|}
\hline \multicolumn{13}{|c|}{ Temperatura máxima $\left({ }^{\circ} \mathrm{C}\right)$} \\
\hline Pontos/bimestre & \multicolumn{2}{|c|}{1} & \multicolumn{2}{|c|}{2} & \multicolumn{2}{|c|}{3} & \multicolumn{2}{|c|}{4} & \multicolumn{2}{|c|}{5} & \multicolumn{2}{|c|}{6} \\
\hline & $\mathrm{A}^{*}$ & $\mathrm{~B}^{* *}$ & $\mathrm{~A}$ & $\mathrm{~B}$ & $\mathrm{~A}$ & $\mathrm{~B}$ & A & B & $\mathrm{A}$ & $\mathrm{B}$ & A & B \\
\hline P1 & 13 & 24 & 22 & 18 & 26 & 21 & 31 & 14 & 27 & 21 & 17 & 20 \\
\hline P4 & 20 & 21 & 37 & 19 & 28 & 20 & 31 & 23 & 27 & 22 & 28 & 18 \\
\hline P8 & 13 & 19 & 37 & 20 & 26 & 20 & 31 & 14 & 28 & 21 & 17 & 20 \\
\hline P9 & 27 & 20 & 23 & 21 & 26 & 21 & 31 & 12 & 27 & 25 & 28 & 19 \\
\hline Nascente & 27 & 19 & 23 & 21 & 26 & 20 & 31 & 23 & 23 & 23 & 20 & 20 \\
\hline Represa Billings & 30 & 18 & 22 & 18 & 28 & 20 & 30 & 21 & 23 & 19 & 20 & 19 \\
\hline
\end{tabular}

$* \mathrm{~A}=$ temperatura do ambiente; $* * \mathrm{~B}=$ temperatura da água 
TABELA 5.6. Resultados dos parâmetros físico-químicos das amostras de água na região em estudo.

\begin{tabular}{|c|c|c|c|c|c|c|c|c|c|c|c|c|c|c|c|c|c|c|c|c|c|c|c|c|}
\hline Amostra/ & \multicolumn{6}{|c|}{ STD (ppm) } & \multicolumn{6}{|c|}{ Turbidez (NTU) } & \multicolumn{6}{|c|}{$\mathrm{pH}$} & \multicolumn{6}{|c|}{ Condutividade Elétrica $(\mu \mathrm{S} / \mathrm{cm})$} \\
\hline & $\mathrm{P} 1$ & $\mathrm{P} 4$ & P8 & P9 & 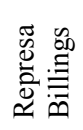 & 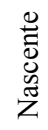 & P1 & $\mathrm{P} 4$ & P8 & P9 & 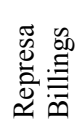 & $\begin{array}{l}\stackrel{0}{*} \\
\stackrel{0}{0} \\
\text { Z } \\
\text { Z }\end{array}$ & P1 & P4 & P8 & P9 & 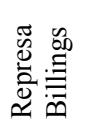 & 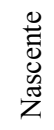 & P1 & P4 & P8 & P9 & 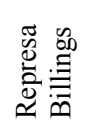 & $\begin{array}{l}\stackrel{\Xi}{0} \\
\mathbb{U} \\
\tilde{Z} \\
\text { Z }\end{array}$ \\
\hline 1 & 93 & 14 & 73 & 145 & 84 & 23 & 3.02 & 1,01 & 14.6 & 2.29 & 5.41 & 0.95 & 4,62 & 6,72 & 4,94 & 5,01 & 9,00 & 6.5 & 185,50 & 28,63 & 146.33 & 289.33 & 164 & 33 \\
\hline 2 & 285 & 9 & 69 & 168 & 90 & 22 & 0.85 & 4,90 & 0,86 & 0,89 & 17,8 & 0.56 & 4,67 & 5,15 & 4,40 & 4,73 & 6,70 & 4.7 & 569,13 & 18,67 & 137,33 & 335,67 & 166 & 45 \\
\hline 3 & 86 & 10 & 82 & 99,6 & 80 & 20 & 1,38 & 42,8 & 4,52 & 6,69 & 11,9 & 0.8 & 4,74 & 5,73 & 5,69 & 4,90 & 7,20 & 4.4 & 173,14 & 19,22 & 163,14 & 199,2 & 171 & 121 \\
\hline 4 & 25 & 49 & 44 & 230 & 81 & 22 & 0,83 & 2,78 & 0,89 & 0,53 & 14,2 & 0.88 & 4,67 & 6,42 & 5,21 & 5,00 & 8,89 & 6.5 & 49,43 & 96,75 & 88,33 & 350,00 & 157 & 20 \\
\hline 5 & 60 & 9 & 50 & 89 & 85 & 20 & 0,96 & 1,03 & 1,15 & 0,95 & 5,60 & 1,10 & 4,57 & 5,14 & 4,99 & 4,90 & 7,40 & 4.4 & 120,20 & 18,14 & 100.6 & 178 & 170 & 15 \\
\hline 6 & 56 & 8,3 & 58 & 133 & 84 & 14 & 3,02 & 1,38 & 14,6 & 2,29 & 32,2 & 0.91 & 4,46 & 5,65 & 4,71 & 5,04 & 7,49 & 5 & 112.25 & 16,80 & 116.25 & 266,5 & 165 & 22 \\
\hline $\begin{array}{c}\text { VMP } \\
2914 / 11 \\
\end{array}$ & \multicolumn{6}{|c|}{ N.A. } & \multicolumn{6}{|c|}{5,0} & \multicolumn{6}{|c|}{6 A 9} & \multicolumn{6}{|c|}{ N.A. } \\
\hline
\end{tabular}




\subsubsection{Aplicação da técnica por ICP-OES e UV-vis}

De acordo com a metodologia por radiação gama foi verificada a quebra de compostos orgânicos, liberando nas amostras de água uma quantidade do metal antes não observada, principalmente em taxas de dose baixa (TAB 5.7).

Somente com a aplicação do processo tradicional feito com a adição do ácido nítrico para acidificar as amostras, digerir e armazenar, posteriormente aplicar às amostras análise quantitativamente pelo ICP-OES, não garante a obtenção de resultados sem interferentes orgânicos, sabendo-se que o ICP-OES alcança altas temperaturas e, mesmo assim, a matéria orgânica complexa não é totalmente mineralizada.

TABELA 5.7. Resultados obtidos pela técnica de ICP-OES em amostras irradiadas e não irradiadas.

\section{Alumínio total $(\mathrm{mg} / \mathrm{l})^{* *} \quad$ Alumínio dissolvido $(\mathrm{mg} / \mathrm{l})$}

\begin{tabular}{cccccccccccc} 
Coleta Dezembro/11 & \multicolumn{1}{c}{ Dose (kGy) } & \multicolumn{1}{c}{ Dose (kGy) } \\
\hline Amostras & 0 & 10 & 20 & 40 & 60 & 0 & 10 & 20 & 40 & 60 \\
\hline Poço 1 & $\mathbf{0 , 6 4}$ & 3,00 & 5,16 & 2,01 & 2,90 & $\mathbf{0 , 5 9}$ & 0,70 & 0,78 & 2,76 & 2,13 \\
Poço 4 & $\mathbf{0 , 0 7}$ & NR & NR & NR & NR & $\mathbf{0 , 0 8}$ & NR & NR & NR & NR \\
Poço 8 & $\mathbf{0 , 6 3}$ & 3,06 & 0,59 & 1,09 & 1,50 & $\mathbf{0 , 5 2}$ & 0,92 & 0,11 & 0,51 & 0,60 \\
Poço 9 & $\mathbf{1 , 5 5}$ & 2,18 & 1,28 & 4,51 & 5,49 & $\mathbf{1 , 3 9}$ & 1,59 & 1,17 & 2,19 & 3,90 \\
Nascente & $\mathbf{0 , 0 5}$ & 0,44 & NR & 0,35 & 0,52 & $<\mathbf{L Q}$ & $<$ LQ & NR* & 0,35 & 0,19 \\
Represa Billings*** & $\mathbf{0 , 5 1}$ & 0,32 & 0,31 & 1,32 & 0,89 & $\mathbf{0 , 1 0}$ & 0,09 & $<$ LQ & 0,77 & 0,51 \\
Branco & $<$ LQ & $<$ LQ & $<$ LQ & $<$ LQ & $<$ LQ & $<$ LQ & $<$ LQ & $<$ LQ & $<$ LQ & $<$ LQ \\
\hline
\end{tabular}

*NR = não realizado; ** VMP da portaria 2914/11 (antiga port. 518/05) =0,2 mg/L; *** VMP da resolução 430/11 (complementa e altera a res. 357/05) =0,1 mg/L e LQ= limite de quantificação $(0,05 \mathrm{mg} / \mathrm{l})$.

Com o processo de filtração obtêm-se íons de $\mathrm{Al}^{3+}$ nas amostras e quando a radiação é aplicada, a concentração desse mesmo alumínio é aumentada devido à quebra dos íons de matéria orgânica complexa presentes que somente são quebrados com alta carga energética emitida através das radiações.

A técnica de UV-vis foi aplicada para verificar a absorção nas amostragens. Primeiramente, a amostra da nascente não irradiada e não acidificada foi comparada com água destilada - branco de laboratório. Verificou-se que houve uma elevação da absorção no comprimento de onda $220 \mathrm{~nm}$, indicando a presença de compostos orgânicos em estudo. 
Novamente, a amostra da nascente foi analisada, agora com a aplicação de baixa dose de radiação gama (20 kGy), sem acidificação e, observou-se um pequeno aumento da absorbância na amostra irradiada, demonstrando a liberação de mais orgânico na matriz (FIG. 5.1). No capítulo 4 é apontado que "as técnicas de ICP-OES e UV-vis são técnicas quantitativas suficientes para determinar a espécie química alumínio mesmo estando complexada ao ácido húmico, não sendo necessária a mineralização deste tipo de solução". Nesse caso, a conclusão apontada não confere com este estudo, já que a aplicação da radiação ionizante permitiu verificarmos a diferença na absorção por UV-vis e no item 5.3.6, através da técnica por ICP-OES foi possível comparar os resultados das amostras irradiadas e não irradiadas, uma diferença de oito vezes maior na concentração de alumínio nas amostras irradiadas.

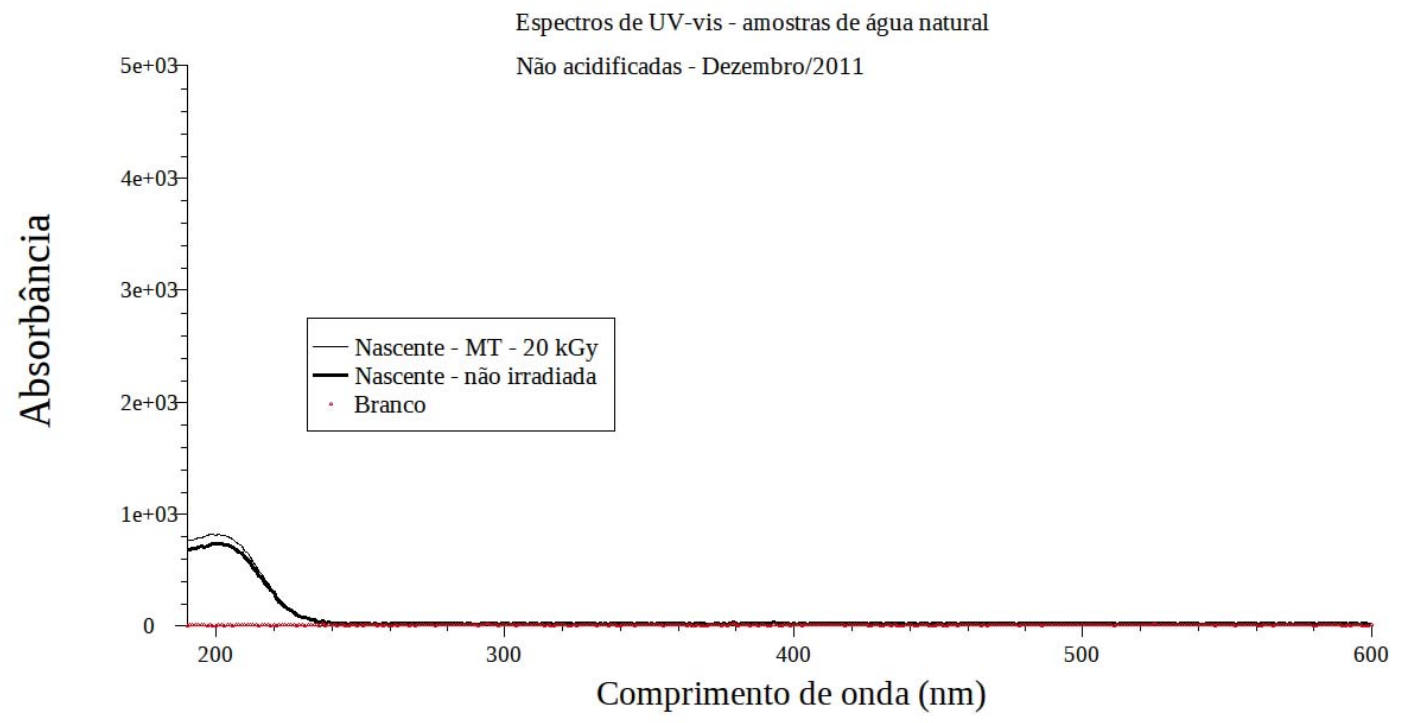

FIGURA 5.1. Resultado do comprimento de onda (nm) e absorbância da amostra de água da nascente.

Verificou-se a absorbância em amostras de água de poço (P9) sem acidificar, através da técnica de UV-vis e observou-se que em doses ainda mais baixa (10 kGy), principalmente em amostras não filtradas - Metal Total (MT) a quantidade de máteria orgânica presente (FIG. 5.2.). Neste caso, verificou-se menor concentração orgânica na amostra filtrada - Metal Dissolvido (MD) aplicando baixa dose. Na dose de $20 \mathrm{kGy}$ aplicada, verifica-se que o comportamento da amostra P9 (MT) é próxima a da amostra P9 
MD, ou seja, uma maior dose aumenta a mineralização de compostos orgânicos complexos presentes.

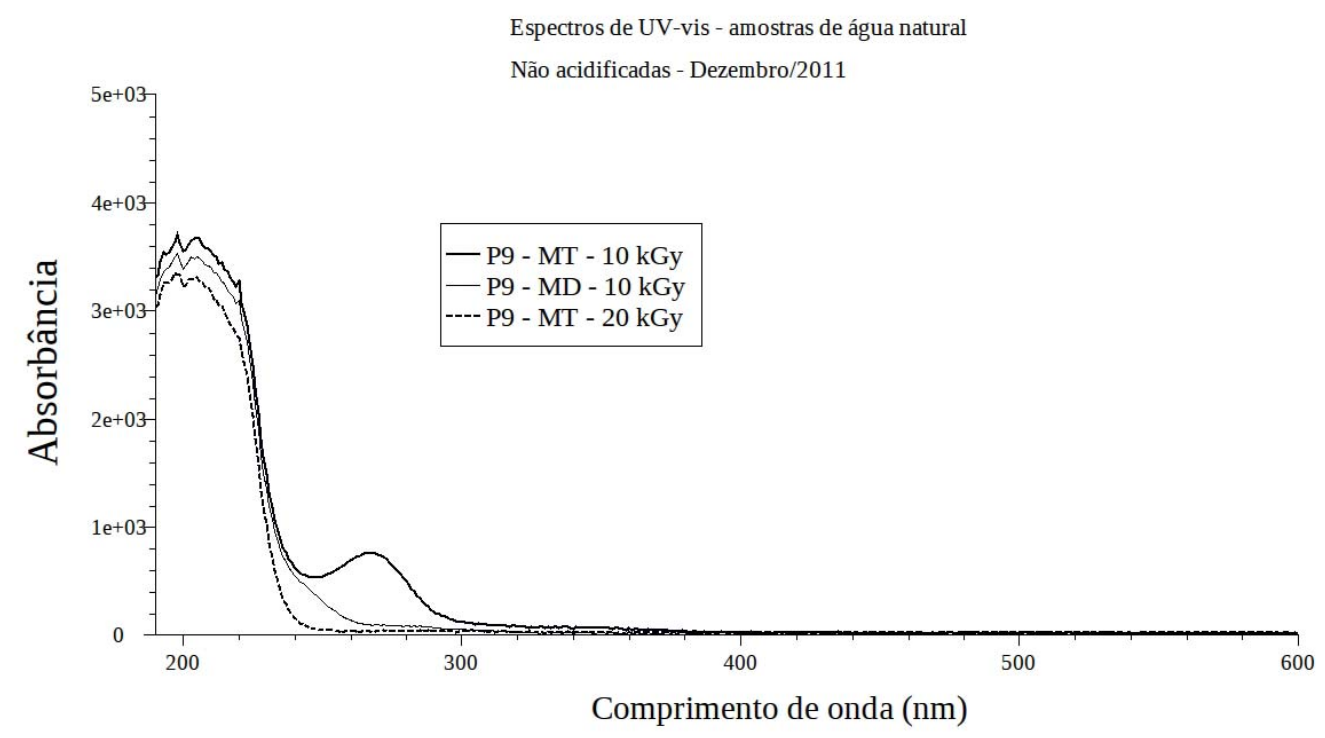

FIGURA. 5.2. Resultado do comprimento de onda (nm) e absorbância da amostra de água de poço (P9).

\subsubsection{Resultado de COT}

De acordo com a TAB. 5.8. a concentração de carbono orgânico total nas amostras irradiadas obtiveram redução após aplicação da irradiação gama 
TABELA 5.8. Avaliação da concentração de COT nas amostras irradiadas e não irradiadas.

\begin{tabular}{|c|c|c|c|c|}
\hline \multirow{2}{*}{ Amostras } & \multirow{2}{*}{ Irradiação gama } & \multicolumn{3}{|c|}{ Concentração (ppm) } \\
\cline { 3 - 5 } & & $\mathrm{CT}$ & $\mathrm{CI}$ & $\mathrm{COT}$ \\
\hline \multirow{2}{*}{ P1 } & Não irradiado & 10,000 & 3,444 & 6,556 \\
\cline { 2 - 5 } & irradiado & 0,873 & 0,245 & 0,628 \\
\hline \multirow{2}{*}{ P8 } & não irradiado & 12,200 & 5,670 & 6,530 \\
\cline { 2 - 5 } & irradiado & 1,060 & 0,762 & 0,298 \\
\hline \multirow{2}{*}{ P9 } & não irradiado & 3,280 & 0,743 & 2,537 \\
\cline { 2 - 5 } & irradiado & 2,750 & 2,440 & 0,310 \\
\hline \multirow{2}{*}{ Represa Billings } & não irradiado & 17,100 & 11,100 & 6,000 \\
\cline { 2 - 5 } & irradiado & 1,360 & 0,832 & 0,528 \\
\hline \multirow{2}{*}{ Nascente } & não irradiado & 1,680 & 1,290 & 0,390 \\
\cline { 2 - 5 } & irradiado & 2,490 & 2,150 & 0,340 \\
\hline
\end{tabular}

CT= Carbono Total; CI= Carbono inorgânico; COT= Carbono Orgânico Total

\subsubsection{Resultado Microbiológico}

$\mathrm{Na}$ água dos poços foram detectados contaminação por bactérias (TAB 5.8). Sabe-se que há matéria orgânica e que esses microrganismos estão agindo na decomposição e, consequentemente, liberando o íon alumínio ao meio, como foi verificado pela metodologia de filtração, onde somente o alumínio em sua forma iônica não é retido. Entretanto, a especiação do alumínio, no primeiro caso (amostras não irradiadas) não é a mesma espécie de alumínio apresentada no segundo caso (amostras irradiadas). 
TABELA 5.9. Resultados microbiológicos das amostras

\begin{tabular}{cccc}
\hline $\begin{array}{c}\text { Amostras } \\
\text { dezembro/11 }\end{array}$ & $\begin{array}{c}\text { E. coli } \\
(\mathrm{NMP} / 100 \mathrm{ml})\end{array}$ & $\begin{array}{c}\text { Coliformes totais } \\
(\mathrm{NMP} / 100 \mathrm{ml})\end{array}$ & Fonte \\
\hline P1 & 517 & 2400 & \\
P4 & Ausente & Ausente & ATIBORÉ (2012) \\
P8 & 13 & 68 & \\
P9 & 2 & 5,2 & Autor \\
\hline Nascente & 5 & 12 & Portaria 2914/11 \\
Branco & Ausente & Ausente & \\
Represa & 2014 & 15531 & \\
\hline VMP** & Ausente & ausente & \\
\hline *NMP: número mais provável; **VMP: Valor Máximo Permitido & &
\end{tabular}

A presença microbiológica das espécies de bactérias estudadas não representa por si só um perigo à saúde, mas indica a possível presença de outros organismos causadores de problemas à saúde. As bactérias do grupo coliforme, em especial a Escherichia coli, representa contaminação de animais de sangue quente recente e indica a possível presença de bactérias patogênicas, vírus entéricos ou parasitas intestinais (AMARAL et al., 2005).

\subsubsection{Interpretação com o PAMQUÁ de dados de domínio público: poços e nascente}

Para a avaliação com o PAMQUÁ ${ }^{\circledR}$ dados dos poços P1, P4, P8, P9 foram tratados, devido ao excesso do metal alumínio que prevaleceu notadamente, seguido dos metais manganês e ferro, durante um ano, com uma frequência bimestral de resultados. Além de dados da nascente e do branco laboratorial (TAB 5.1 e 5.9). 
TABELA 5.10. Resultado de metais em nascente da região da represa Billings

\begin{tabular}{|c|c|c|c|c|c|c|c|c|c|c|c|c|}
\hline$\stackrel{0}{\Xi}$ & Amostras & As & $\mathrm{Al}$ & $\mathrm{Cu}$ & $\mathrm{Fe}$ & $\mathrm{Hg}$ & $\mathrm{Mn}$ & $\mathrm{Pb}$ & $\mathrm{Zn}$ & $\mathrm{Ba}$ & $\mathrm{Cr}$ & $\mathrm{Cd}$ \\
\hline & & \multicolumn{11}{|c|}{ Agosto 2011} \\
\hline \multirow[t]{3}{*}{1} & Nascente & $<\mathrm{LQ}$ & $<\mathrm{LQ}$ & $<\mathrm{LQ}$ & $<\mathrm{LQ}$ & $<\mathrm{LQ}$ & $<\mathrm{LQ}$ & $<\mathrm{LQ}$ & $<\mathrm{LQ}$ & $<\mathrm{LQ}$ & $<\mathrm{LQ}$ & $<\mathrm{LQ}$ \\
\hline & Branco & $<\mathrm{LQ}$ & $<\mathrm{LQ}$ & $<\mathrm{LQ}$ & $<\mathrm{LQ}$ & $<\mathrm{LQ}$ & $<\mathrm{LQ}$ & $<\mathrm{LQ}$ & $<\mathrm{LQ}$ & $<\mathrm{LQ}$ & $<\mathrm{LQ}$ & $<\mathrm{LQ}$ \\
\hline & & \multicolumn{11}{|c|}{ Outubro 2011} \\
\hline \multirow[t]{3}{*}{2} & Nascente & $<\mathrm{LQ}$ & $<\mathrm{LQ}$ & $<\mathrm{LQ}$ & $<\mathrm{LQ}$ & $<\mathrm{LQ}$ & $<\mathrm{LQ}$ & $<\mathrm{LQ}$ & $<\mathrm{LQ}$ & $<\mathrm{LQ}$ & $<\mathrm{LQ}$ & $<\mathrm{LQ}$ \\
\hline & Branco & $<\mathrm{LQ}$ & $<\mathrm{LQ}$ & $<\mathrm{LQ}$ & $<\mathrm{LQ}$ & $<\mathrm{LQ}$ & $<\mathrm{LQ}$ & $<\mathrm{LQ}$ & 0,104 & $<\mathrm{LQ}$ & $<\mathrm{LQ}$ & $<\mathrm{LQ}$ \\
\hline & & \multicolumn{11}{|c|}{ Dezembro 2011} \\
\hline \multirow[t]{3}{*}{3} & Nascente & $<\mathrm{LQ}$ & 0,05 & $<\mathrm{LQ}$ & $<\mathrm{LQ}$ & $<\mathrm{LQ}$ & $<\mathrm{LQ}$ & $<\mathrm{LQ}$ & $<\mathrm{LQ}$ & $<\mathrm{LQ}$ & $<\mathrm{LQ}$ & $<\mathrm{LQ}$ \\
\hline & Branco & $<\mathrm{LQ}$ & $<\mathrm{LQ}$ & $<\mathrm{LQ}$ & $<\mathrm{LQ}$ & $<\mathrm{LQ}$ & $<\mathrm{LQ}$ & $<\mathrm{LQ}$ & $<\mathrm{LQ}$ & $<\mathrm{LQ}$ & $<\mathrm{LQ}$ & $<\mathrm{LQ}$ \\
\hline & & \multicolumn{11}{|c|}{ Março 2012} \\
\hline \multirow[t]{3}{*}{4} & Nascente & $<\mathrm{LQ}$ & $<\mathrm{LQ}$ & $<\mathrm{LQ}$ & $<\mathrm{LQ}$ & $<\mathrm{LQ}$ & $<\mathrm{LQ}$ & $<\mathrm{LQ}$ & $<\mathrm{LQ}$ & $<\mathrm{LQ}$ & $<\mathrm{LQ}$ & $<\mathrm{LQ}$ \\
\hline & Branco & $<\mathrm{LQ}$ & $<\mathrm{LQ}$ & $<\mathrm{LQ}$ & $<\mathrm{LQ}$ & $<\mathrm{LQ}$ & $<\mathrm{LQ}$ & $<\mathrm{LQ}$ & $<\mathrm{LQ}$ & $<\mathrm{LQ}$ & $<\mathrm{LQ}$ & $<\mathrm{LQ}$ \\
\hline & & \multicolumn{11}{|c|}{ Maio 2012} \\
\hline \multirow[t]{3}{*}{5} & Nascente & $<\mathrm{LQ}$ & $<\mathrm{LQ}$ & $<\mathrm{LQ}$ & $<\mathrm{LQ}$ & $<\mathrm{LQ}$ & $<\mathrm{LQ}$ & $<\mathrm{LQ}$ & $<\mathrm{LQ}$ & $<\mathrm{LQ}$ & $<\mathrm{LQ}$ & $<\mathrm{LQ}$ \\
\hline & Branco & $<\mathrm{LQ}$ & $<\mathrm{LQ}$ & $<\mathrm{LQ}$ & $<\mathrm{LQ}$ & $<\mathrm{LQ}$ & $<\mathrm{LQ}$ & $<\mathrm{LQ}$ & $<\mathrm{LQ}$ & $<\mathrm{LQ}$ & $<\mathrm{LQ}$ & $<\mathrm{LQ}$ \\
\hline & & \multicolumn{11}{|c|}{ Julho 2012} \\
\hline \multirow[t]{2}{*}{6} & Nascente & $<\mathrm{LQ}$ & $<\mathrm{LQ}$ & $<\mathrm{LQ}$ & $<\mathrm{LQ}$ & $<\mathrm{LQ}$ & $<\mathrm{LQ}$ & $<\mathrm{LQ}$ & $<\mathrm{LQ}$ & $<\mathrm{LQ}$ & $<\mathrm{LQ}$ & $<\mathrm{LQ}$ \\
\hline & Branco & $<\mathrm{LQ}$ & $<\mathrm{LQ}$ & $<\mathrm{LQ}$ & $<\mathrm{LQ}$ & $<\mathrm{LQ}$ & $<\mathrm{LQ}$ & $<\mathrm{LQ}$ & $<\mathrm{LQ}$ & $<\mathrm{LQ}$ & $<\mathrm{LQ}$ & $<\mathrm{LQ}$ \\
\hline \multicolumn{2}{|r|}{ LQ } & 0,005 & 0,050 & 0,005 & 0,050 & 0,0002 & 0,005 & 0,005 & 0,005 & 0,005 & 0,005 & 0,001 \\
\hline & VMP & 0,010 & 0,200 & 2,00 & 0,300 & 0,001 & 0,100 & 0,010 & 5,000 & 0,700 & 0,050 & 0,005 \\
\hline
\end{tabular}

LQ: limite de quantificação; VMP: valor máximo permitido; MS: Ministério da Saúde. Negrito destaca os valores acima do VMP.

\subsubsection{Avaliação do alumínio nas águas dos poços com o PAMQUÁ ${ }^{\circledR}$}

Repetiu-se a espécie química alumínio (Al) como elemento para esta avaliação, em resultados sem irradiação, de acordo com a ocorrência de resultados acima do VMP durante o ano de 2011-12 do projeto ATIBORÉ (TAB. 5.1, 5.11). Os resultados do PAMQUÁ encontram-se na TAB. 5.12 a,b,c,d,e. 
TABELA 5.11. Resultado de alumínio total durante o ano 2011-12 nos poços e nascente (adaptado de ATIBORE, 2012).

\begin{tabular}{|c|c|c|}
\hline Localização & Parâmetros & Resultado \\
\hline \multirow[t]{4}{*}{ Poço P1 } & Último resultado (Valor Max. mensal) & $0,360 \mathrm{mg} / 1$ \\
\hline & $\mathrm{N}^{\mathrm{o}}$ de resultados acima do limite & 6 \\
\hline & $\mathrm{N}^{\mathrm{o}}$ de monitoramentos executados & 6 \\
\hline & Percentual de não-conformidade & $100 \%$ \\
\hline \multirow[t]{5}{*}{ Poço P4 } & Último resultado (Valor Max. Anual) & $0,080 \mathrm{mg} / 1$ \\
\hline & $\mathrm{N}^{\mathrm{o}}$ de resultados acima do limite & 2 \\
\hline & $\mathrm{N}^{\mathrm{o}}$ de monitoramentos executados & 6 \\
\hline & Percentual de não-conformidade & $33 \%$ \\
\hline & Último resultado (Valor Max. Anual) & $1,000 \mathrm{mg} / 1$ \\
\hline \multirow[t]{3}{*}{ Poço P8 } & $\mathrm{N}^{\mathrm{o}}$ de resultados acima do limite & 5 \\
\hline & $\mathrm{N}^{\mathrm{o}}$ de monitoramentos executados & 5 \\
\hline & Percentual de não-conformidade & $100 \%$ \\
\hline \multirow[t]{4}{*}{ Poço P9 } & Último resultado (Valor Max. Anual) & $1,680 \mathrm{mg} / 1$ \\
\hline & $\mathrm{N}^{\mathrm{o}}$ de resultados acima do limite & 6 \\
\hline & $\mathrm{N}^{\mathrm{o}}$ de monitoramentos executados & 6 \\
\hline & Percentual de não-conformidade & $100 \%$ \\
\hline \multirow[t]{4}{*}{ Nascente } & Último resultado (Valor Max. Anual) & $0,05 \mathrm{mg} / 1$ \\
\hline & $\mathrm{N}^{\mathrm{o}}$ de resultados acima do limite & 0 \\
\hline & $\mathrm{N}^{\mathrm{o}}$ de monitoramentos executados & 6 \\
\hline & Percentual de não-conformidade & $0 \%$ \\
\hline \multicolumn{2}{|c|}{ Portaria 2914/11 - Ministério da Saúde } & $\mathrm{VMP}=0,2 \mathrm{mg} / \mathrm{l}$ \\
\hline
\end{tabular}

Para a aplicação do PAMQUÁ é necessário responder a três perguntas, de modo a pontuar e verificar os níveis de alerta (TAB.5.12 a,b,c,d,e).

1. Qual é a frequência de monitoramento?

Resposta: Bimestral

2. Qual é a ocorrência de não conformidade?

Resposta: 100\% (Poço 1,8 e 9), 33\% (P4), 0\% (nascente) 
3. Qual foi o último resultado?

Resposta: 0,360 mg/l (Poço 1), 0,080 mg/l (P4), 1,680 mg/l (Poço 9) e 0,00 mg/1 (nascente). 
Tabela 5.12a. PAMQUÁ: Resultado do poço 1

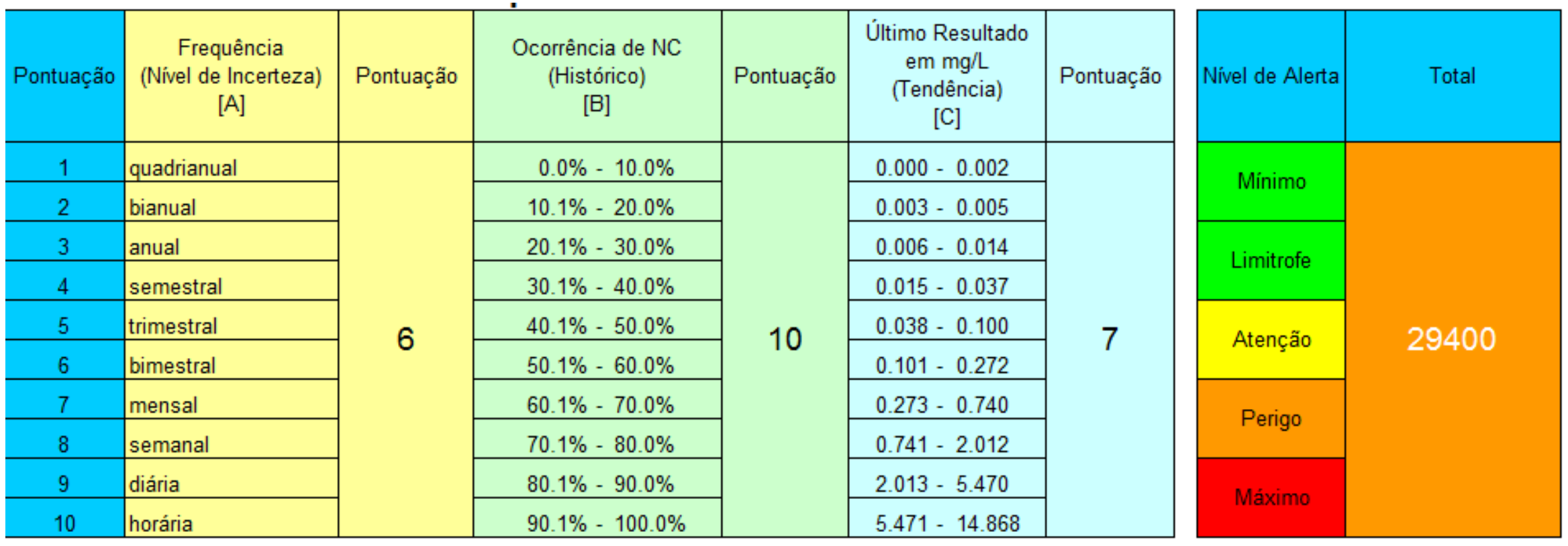


TABELA 5.12.b. PAMQUÁ: Resultado do poço 4

\begin{tabular}{|c|c|c|c|c|c|c|c|c|}
\hline Pontuação & $\begin{array}{c}\text { Frequência } \\
\text { (Nivel de Incerteza) } \\
{[\mathrm{A}]}\end{array}$ & Pontuação & $\begin{array}{c}\text { Ocorrência de NC } \\
\text { (Histórico) } \\
{[B]}\end{array}$ & Pontuação & $\begin{array}{c}\text { Último Resultado } \\
\text { em mg/L } \\
\text { (Tendência) } \\
\text { [C] }\end{array}$ & Pontuação & Nivel de Alerta & Total \\
\hline 1 & quadrianual & \multirow{10}{*}{6} & $0.0 \%-10.0 \%$ & \multirow{10}{*}{4} & $0.000-0.002$ & \multirow{10}{*}{5} & \multirow{4}{*}{ Limitrofe } & \multirow{10}{*}{2400} \\
\hline 2 & bianual & & $10.1 \%-20.0 \%$ & & $0.003-0.005$ & & & \\
\hline 3 & anual & & $20.1 \%-30.0 \%$ & & $0.006-0.014$ & & & \\
\hline 4 & semestral & & $30.1 \%-40.0 \%$ & & $0.015-0.037$ & & & \\
\hline 5 & trimestral & & $40.1 \%-50.0 \%$ & & $0.038-0.100$ & & \multirow{2}{*}{ Atenção } & \\
\hline 6 & bimestral & & $50.1 \%-60.0 \%$ & & $0.101-0.272$ & & & \\
\hline 7 & mensal & & $60.1 \%-70.0 \%$ & & $0.273-0.740$ & & \multirow{2}{*}{ Perigo } & \\
\hline 8 & semanal & & $70.1 \%-80.0 \%$ & & $0.741-2.012$ & & & \\
\hline 9 & diária & & $80.1 \%-90.0 \%$ & & $2.013-5.470$ & & \multirow{2}{*}{ Máximo } & \\
\hline 10 & horária & & $90.1 \%-100.0 \%$ & & $5.471-14.868$ & & & \\
\hline
\end{tabular}


TABELA 5.12.c. PAMQUÁ: Resultado do poço 8

\begin{tabular}{|c|c|c|c|c|c|c|c|c|}
\hline Pontuação & $\begin{array}{c}\text { Frequência } \\
\text { (Nivel de Incerteza) } \\
{[\mathrm{A}]}\end{array}$ & Pontuação & $\begin{array}{c}\text { Ocorrência de NC } \\
\text { (Histórico) } \\
{[\mathrm{B}]}\end{array}$ & Pontuação & $\begin{array}{l}\text { Último Resultado } \\
\text { em mg/L } \\
\text { (Tendência) } \\
\text { [C] }\end{array}$ & Pontuação & Nivel de Alerta & Total \\
\hline 1 & quadrianual & \multirow{10}{*}{6} & $0.0 \%-10.0 \%$ & \multirow{10}{*}{10} & $0.000-0.002$ & \multirow{10}{*}{8} & \multirow{2}{*}{ Mínimo } & \multirow{10}{*}{38400} \\
\hline 2 & bianual & & $10.1 \%-20.0 \%$ & & $0.003-0.005$ & & & \\
\hline 3 & anual & & $20.1 \%-30.0 \%$ & & $0.006-0.014$ & & \multirow{2}{*}{ Limitrofe } & \\
\hline 4 & semestral & & $30.1 \%-40.0 \%$ & & $0.015-0.037$ & & & \\
\hline 5 & trimestral & & $40.1 \%-50.0 \%$ & & $0.038-0.100$ & & \multirow{2}{*}{ Atenção } & \\
\hline 6 & bimestral & & $50.1 \%-60.0 \%$ & & $0.101-0.272$ & & & \\
\hline 7 & mensal & & $60.1 \%-70.0 \%$ & & $0.273-0.740$ & & \multirow{2}{*}{ Perigo } & \\
\hline 8 & semanal & & $70.1 \%-80.0 \%$ & & $0.741-2.012$ & & & \\
\hline 9 & diária & & $80.1 \%-90.0 \%$ & & $2.013-5.470$ & & \multirow{2}{*}{ Máximo } & \\
\hline 10 & horária & & $90.1 \%-100.0 \%$ & & $5.471-14.868$ & & & \\
\hline
\end{tabular}


TABELA 5.12.d. PAMQUÁ: Resultado do poço 9

\begin{tabular}{|c|c|c|c|c|c|c|c|c|}
\hline Pontuação & $\begin{array}{c}\text { Frequência } \\
\text { (Nivel de Incerteza) } \\
{[\mathrm{A}]}\end{array}$ & Pontuação & $\begin{array}{l}\text { Ocorrência de NC } \\
\text { (Histórico) } \\
{[\mathrm{B}]}\end{array}$ & Pontuação & $\begin{array}{l}\text { Último Resultado } \\
\text { em mg/L } \\
\text { (Tendência) } \\
\text { [C] }\end{array}$ & Pontuação & Nivel de Alerta & Total \\
\hline 1 & quadrianual & \multirow{10}{*}{6} & $0.0 \%-10.0 \%$ & \multirow{10}{*}{10} & $0.000-0.002$ & \multirow{10}{*}{8} & \multirow{2}{*}{ Mínimo } & \multirow{10}{*}{38400} \\
\hline 2 & bianual & & $10.1 \%-20.0 \%$ & & $0.003-0.005$ & & & \\
\hline 3 & anual & & $20.1 \%-30.0 \%$ & & $0.006-0.014$ & & \multirow{2}{*}{ Limitrofe } & \\
\hline 4 & semestral & & $30.1 \%-40.0 \%$ & & $0.015-0.037$ & & & \\
\hline 5 & trimestral & & $40.1 \%-50.0 \%$ & & $0.038-0.100$ & & \multirow{2}{*}{ Atenção } & \\
\hline 6 & bimestral & & $50.1 \%-60.0 \%$ & & $0.101-0.272$ & & & \\
\hline 7 & mensal & & $60.1 \%-70.0 \%$ & & $0.273-0.740$ & & \multirow{2}{*}{ Perigo } & \\
\hline 8 & semanal & & $70.1 \%-80.0 \%$ & & $0.741-2.012$ & & & \\
\hline 9 & diária & & $80.1 \%-90.0 \%$ & & $2.013-5.470$ & & \multirow{2}{*}{ Máximo } & \\
\hline 10 & horária & & $90.1 \%-100.0 \%$ & & $5.471-14.868$ & & & \\
\hline
\end{tabular}


TABELA 5.12 e. PAMQUÁ: Resultado da nascente

\begin{tabular}{|c|c|c|c|c|c|c|c|c|}
\hline Pontuação & $\begin{array}{c}\text { Frequência } \\
\text { (Nivel de Incerteza) } \\
{[\mathrm{A}]}\end{array}$ & Pontuação & $\begin{array}{c}\text { Ocorrência de NC } \\
\text { (Histórico) } \\
{[B]}\end{array}$ & Pontuação & $\begin{array}{l}\text { Último Resultado } \\
\text { em mg/L } \\
\text { (Tendência) } \\
\text { [C] }\end{array}$ & Pontuação & Nivel de Alerta & Total \\
\hline 1 & quadrianual & \multirow{10}{*}{6} & $0.0 \%-10.0 \%$ & \multirow{10}{*}{0} & $0.000-0.002$ & \multirow{10}{*}{5} & Mínimo & \multirow{10}{*}{0} \\
\hline 2 & bianual & & $10.1 \%-20.0 \%$ & & $0.003-0.005$ & & & \\
\hline 3 & anual & & $20.1 \%-30.0 \%$ & & $0.006-0.014$ & & \multirow{2}{*}{ Limitrofe } & \\
\hline 4 & semestral & & $30.1 \%-40.0 \%$ & & $0.015-0.037$ & & & \\
\hline 5 & trimestral & & $40.1 \%-50.0 \%$ & & $0.038-0.100$ & & \multirow{2}{*}{ Atenção } & \\
\hline 6 & bimestral & & $50.1 \%-60.0 \%$ & & $0.101-0.272$ & & & \\
\hline 7 & mensal & & $60.1 \%-70.0 \%$ & & $0.273-0.740$ & & \multirow{2}{*}{ Perigo } & \\
\hline 8 & semanal & & $70.1 \%-80.0 \%$ & & $0.741-2.012$ & & & \\
\hline 9 & diária & & $80.1 \%-90.0 \%$ & & $2.013-5.470$ & & \multirow{2}{*}{ Máximo } & \\
\hline 10 & horária & & $90.1 \%-100.0 \%$ & & $5.471-14.868$ & & & \\
\hline
\end{tabular}


O resultado mostra o nível de alerta máximo aos poços $\mathrm{P} 1$ e $\mathrm{P} 9$, nível de alerta perigo ao Poço P4 e para a nascente o nível de alerta mínimo.

Realizou-se uma investigação do local dos poços e nascente. Ao redor dos poços foi verificada a proximidade de fossas assépticas (distância menor que 30 metros) e construções inadequadas dos poços, além de fezes de animais, proximidade com a represa Billings, falta de vedação das tampas dos poços e grande quantidade de lixo nos terrenos, o que favorece a contaminação dessas águas por substâncias orgânicas e consequentemente, contaminação microbiológica na decomposição da matéria orgânica e no sedimento dos poços, incluindo argilas, inferindo a liberação do alumínio na sua forma mais perigosa à saúde humana que é a iônica. O poço P4 não apresenta proximidade com fossas e está isento de contaminação microbiológica, entretanto, apresentou excesso de alumínio durante o período chuvoso das coletas, sugerindo o uso de filtro para a retenção do sólidos particulados.

As águas subterrâneas podem ser contaminadas por meio da infiltração oriunda de fossas rudimentares e pelo escoamento superficial da água da chuva em contato com o esgoto doméstico lançado a céu aberto.

\subsection{Conclusão}

O processo de irradiação gama aplicado como pré-tratamento de águas naturais representada uma alternativa Processo de Oxidação Avançada para degradar a matéria orgânica. Após o processo de irradiação ionizante verificou-se a liberação do alumínio até oito vezes a quantidade detectada em amostras não irradiadas. A quebra da matéria orgânica nessas amostras é fundamental uma vez que os poços escolhidos foram classificados como poços rasos e são consumíveis pela comunidade local.

Com a ferramenta PAMQUÁ foi possível ter um acompanhamento histórico do metal alumínio nos quatro poços e nascente, mesmo o estudo contemplando apenas um ano de amostragem, porém deve ser observada a frequência do monitoramento, neste caso bimestralmente. Dessa forma, o PAMQUÁ confirma que o local necessita ainda mais de monitoramento e controle imediato, principalmente por serem águas consumidas e pela preservação da nascente.

Além disso, é necessário avaliar a localização e a construção dos poços que apresentaram concentrações de alumínio $>0,2 \mathrm{mg} / 1$, bem como o uso e ocupação do seu entorno, como uma primeira etapa de investigação da origem da contaminação orgânica e inorgânica. 
Inicialmente a ferramenta PAMQUÁ direciona seus resultados ao público de pesquisadores, cujas suas pesquisas são voltadas às questões da contaminação e da qualidade de recursos hídricos e, potencialmente pode se tornar uma ferramenta de uso público, divulgação em livros didáticos, onde o público possa avaliar outras fontes de dados e ajudar a monitorar a situação real da qualidade da água na cidade em que vive.

\section{REFERÊNCIAS BIBLIOGRÁFICAS}

AMERICAN PUBLIC HEALTH ASSOCIATION (APHA). Standard methods for the examination of water and wastewater. 21 th ed. Washigton, DC. (1999).

ASSOCIAÇÃO DE TURISMO DA ILHA DO BORORÉ - Ilha do Bororé Saudável. São Paulo: ATIBORÉ. Disponível em: <http://ilhadobororesaudavel.blogspot.com.br/ 2011/11/estudo-da-contaminacao-por-metais-e.html> e $\quad<$ http://ilhadobororesaudavel. blogspot.com.br/2012_03_01_archive.html> (2012).

CLARKE, N.; DANIELSSON, L.; SPARÉN, A. Analytical Methodology for the Determination of Aluminium fractions in Natural Fresh Waters (Technical Report). Internation Union of Pure and Applied Chemistry (IUPAC) v.68, n.8. pp.1597-1638 (1996).

COMPANHIA AMBIENTAL DO ESTADO DE SÃO PAULO. Relatório de qualidade das águas interiores do estado de São Paulo. 2000 / CETESB. São Paulo: CETESB, v.1: 214p; v.2: Resultados dos parâmetros e indicadores de qualidade das águas. 138p. Disponível em: <http://www.cetesb.sp.gov.br/agua/aguas-superficiais/35-publicacoes-/$\underline{\text { relatorios }}>$ (2001).

COMPANHIA AMBIENTAL DO ESTADO DE SÃO PAULO. Relatório de qualidade das águas interiores do estado de São Paulo. 2001 / CETESB. São Paulo: CETESB, 227p. + ANEXOS 23p. Disponível em: < http://www.cetesb.sp.gov.br/agua/aguassuperficiais/35-publicacoes-/-relatorios $>$ (2002).

COMPANHIA AMBIENTAL DO ESTADO DE SÃO PAULO. Relatório de qualidade das águas interiores do estado de São Paulo. 2002 / CETESB. São Paulo: CETESB, 279p. Disponível em: $\quad<$ http://www.cetesb.sp.gov.br/agua/aguas-superficiais/35publicacoes-/-relatorios $>$ (2003).

COMPANHIA AMBIENTAL DO ESTADO DE SÃO PAULO. Relatório de qualidade das águas interiores do estado de São Paulo. 2003 / CETESB. São Paulo: CETESB, 273p. Disponível em: $\quad<$ http://www.cetesb.sp.gov.br/agua/aguas-superficiais/35publicacoes-/-relatorios $>$ (2004). 
COMPANHIA AMBIENTAL DO ESTADO DE SÃO PAULO. Relatório de qualidade das águas interiores do estado de São Paulo. 2004 / CETESB. São Paulo: CETESB, 307p. Disponível em: $<$ http://www.cetesb.sp.gov.br/agua/aguas-superficiais/35publicacoes-/-relatorios $>$ (2005).

COMPANHIA AMBIENTAL DO ESTADO DE SÃO PAULO. Relatório de qualidade das águas interiores do estado de São Paulo. 2005 / CETESB. São Paulo: CETESB, 488p. Disponível em: $<$ http://www.cetesb.sp.gov.br/agua/aguas-superficiais/35publicacoes-/-relatorios $>$ (2006).

COMPANHIA AMBIENTAL DO ESTADO DE SÃO PAULO. Relatório de qualidade das águas interiores do estado de São Paulo. 2006 / CETESB. São Paulo: CETESB, 327p. Disponível em: $<$ http://www.cetesb.sp.gov.br/agua/aguas-superficiais/35publicacoes-/-relatorios $>$ (2007).

COMPANHIA AMBIENTAL DO ESTADO DE SÃO PAULO. Relatório de qualidade das águas interiores do estado de São Paulo. 2007 / CETESB. São Paulo: CETESB, 528p + anexos. Disponível em: < http://www.cetesb.sp.gov.br/agua/aguas-superficiais/35publicacoes-/-relatorios $>$ (2008).

COMPANHIA AMBIENTAL DO ESTADO DE SÃO PAULO. Relatório de qualidade das águas interiores do estado de São Paulo. 2008 / CETESB. São Paulo: CETESB, 537p. Disponível em: $<$ http://www.cetesb.sp.gov.br/agua/aguas-superficiais/35publicacoes-/-relatorios $>$ (2009).

COMPANHIA AMBIENTAL DO ESTADO DE SÃO PAULO. Relatório de qualidade das águas interiores do estado de São Paulo. 2009 [recurso eletrônico] / CETESB. São Paulo: CETESB, $310 \mathrm{p}+$ anexos. Disponível em: < http://www.cetesb.sp.gov.br/agua/aguas-superficiais/35-publicacoes-/-relatorios $>$ (2010).

COMPANHIA DE SANEAMENTO BÁSICO DO ESTADO DE SÃO PAULO. Diagnóstico Hidrogeológico da Região Metropolitana de São Paulo, Relatório Final. Convênio SABESP/CEPAS-IGc-USP. São Paulo, 2008

CONSELHO NACIONAL DO MEIO AMBIENTE. Resolução $n^{\circ}$ 357, de 17 de março de 2005. Diário Oficial da União. Brasília: CONAMA. 23p. Disponível em: $<$ http://www.mma.gov.br/port/conama> Acesso em: 30 jun. 2009.

CONSELHO NACIONAL DO MEIO AMBIENTE. Resolução $n^{\circ}$ 396, de 03 de abril de 2008. Diário Ofícial da União. Brasília: 66, seção 1, CONAMA. 64-68. Disponível em: < http://www.mma.gov.br/port/conama/legiabre.cfm?codlegi=562> Acesso em: 30 jun. 2009.

FURMAN, N.H. (Ed.) Standard methods of chemical analysis. 6a. ed. New York, Van Nostrand, 1962. 
GIROUX, S., AURY, S., RUBINI, P., PARANT, S., DESMURS, J.R., DURY, M. A spectroscopic investigation of the complexing ability of catecholate or salicylate derivatives towards aluminium(III). Polyhedron. V. 23(15), 30, 2393-2404 (2004).

GUPTA, S.; VEER, B.; ANITHA, M.L.; HEGDE, L.; ZECCA, R.M.; GARRUTO, R. Rewiew: aluminium in Alzheimer's disease: are we still at a crossroad? Cellular and Molecular Life Sciences. Vol. n 62, pp. 143-158 (2005).

INTERNACIONAL WATER AND SANITATION CENTRE - IRC. Peri-Urban Water Conflicts: Supporting dialogue and negotiation. Editores: Butterworth, J., Ducrot, R., Faysse, N. \& Janakarajan, S. Technical Paper Series; no 50. 128 p. Delft, the Netherlands, 2007.

INTERNATIONAL ORGANIZATION FOR STANDARDIZATION - ISO 11885: 2009 Water Quatily Determination of 33 elements by Inductively Coupled Plasma Optical Emission Spectrometry. 2007. Disponível em: https://shop.austrianstandards.at/Preview.action; jsessionid=CF7234FBAC2BCFDD35A4593A11BD4700?prev iew $=\&$ dokkey $=347061 \&$ selectedLocale $=$ en Acesso em: 14/09/2011.

KLEN, G.L. Aluminum: new recognition of an old problem. Current opinion in pharmacology. 2005, 5: $637-640$.

KOREIMANN, C.; GRATH, J.; WINKLER, G.; NAGY, W.; VOGEL, W.R. Groundwater monitoring in Europe. Copenhagen: European Environmental Agency, 1996. (Topic Report, 10/96). Disponível em: <http://www.eea.europa.eu/publications/ latest\#c9=all\&c14=\&c12=\&c7=en>. Acessado em 15.08.2010.

MENDONÇA, E.S.; MOURA FILHO, W.; COSTA, L.M. Organic matter and chemical characteristics of aggregates from a Red-Yellow Latosol under natural forest, rubber plant, and grass in Brazil. In: WILSON, W.S. (Ed.). Advances in soil organic matter research: the impact on agriculture and the environment. Cambridge: The Royal Society of Chemistry, p.185-195. (1991).

MERCANTE, C. T. J.; J. S. PEREIRA; L. S. MARUYAMA; CASTRO, P. M. G.; MENEZES, L. C. B.; SENDACZ, S.; DI GENARO, A. C. Qualidade da água de efluentes de pesqueiros situados na bacia do Alto Tietê. Bioikos, Campinas, 25(1):41-52, jan./jun., 2011.

MEYER-BARON, M., SHAPER, M., KNAPP, G., THRIEL, C. Occupational aluminium exposure: Evidence insupport of its neurobehavioral impact. NeuroToxicology. 2007, 28: 1068 - 1078 (2007).

NIXON, S.; GRTH, J.; BOGESTRAND, J. Eurowaternet: the European Environment Agency's Monitoring and Information Network for Inland Water Resources - technical guidelines for implementation. Copenhagem: European Environment Agency, 1998. (Technical Report, 7).

PASCALICCHIO, A.E., Contaminação por metais pesados. São Paulo: Associação de Profissionais em Ciência Ambiental. p.31, 40-41.(2002) 
PRIEST, N.D., O'DONNELL, T.V. (Ed.) Managing Health in the Aluminium Industry. International Primary Aluminium Institute London e The Aluminum Association Washington, DC. Disponível em: < http://www.world-aluminium.org/media/filer_public/ 2013/01/15/f10000116.pdf $>$ Acesso em 22 set. 2013.

QUINTAES, K.D. Utensílio para alimentos e implicações nutricionais. Rev Nutr.13:151156. (2000)

RODRIGUES, L.L; SANT'ANNA,C.; TUCCI, A. Chlorophyceae das Represas Billings (Braço Taquacetuba) e Guarapiranga, SP, Brasil. Revista Brasil Botânica. V.33, n2, p. 247-264 (2010). Disponível em: < http://www.scielo.br/pdf/rbb/v33n2/a06v33n2.pdf>

SCOTT, W.W. Standard methods of chemical analysis., v.2, 5a ed. New York, Van Nostrand,1952.

TOMIJENOVIC, L. Aluminum and Alzheimer's Disease: After a Century of Controversy, Is there a Plausible Link?, J. Alzheimers Disease, 23(4), pp.567-598, 2011.

UNITED STATES. Environmental Protection Agency. Method 6010C: Inductively coupled plasma - atomic emission spectrometry. San Francisco: EPA, 34p. 2007.

VANLOOT, P., BOUDENNE, J.-L., BRACH-PAPA, C., SERGENT, M., COULOMBA, B. 2007., An experimental design to optimize the flow extraction parameters for the selective removal of $\mathrm{Fe}(\mathrm{III})$ and $\mathrm{Al}(\mathrm{III})$ in aqueous samples using salicylic acid grafted on Amberlite XAD-4 and final determination by GF-AAS. Journal of Hazardous Materials, v. 147, pp.463-470, 2007.

WORD HEALTH ORGANIZATION WORKING GROUP (WHO). Health impact of acidic deposition. Science of the total environment. V.52, pp.157-187, 1986. 


\section{APLICAÇÃO DA RADIAÇÃO EM MEMBRANAS POLIMÉRICAS ENXERTADAS E QUIMICAMENTE MODIFICADAS: PROPOSTA PARA REMEDIAÇÃO DO ALUMÍNIO EM ÁGUA POTÁVEL}

\subsection{Introdução}

Os polímeros estão cada vez mais em nosso cotidiano e se tornaram essenciais para a vida moderna. A maioria dos objetos utilizados nos dias atuais - eletrodomésticos, computadores, automóveis, brinquedos, calçados, embalagens diversas e roupas - possui polímeros na sua composição.

Membranas poliméricas são materiais tecnológicos que vem sendo desenvolvidos para aplicações diversas, onde a mais popular é o tratamento de água. Membranas de nylon ${ }^{\circledR}$ já estão sendo utilizadas para ultrafiltração de metais traços e aplicadas aos estudos de contaminação ambiental (KHAN et al., 2009).

Um método conhecido para complexar metais tóxicos é o tratamento por materiais adsorventes quelantes (APOSHIAN et al., 1995; TANDY et al., 2004,). O ácido salicílico é um quelante que possui propriedades adsorvedoras, queratolíticas e antimicrobianas (ISA et al., 2013), tem sido muitas vezes escolhido para determinação espectrofotométrica do metal alumínio em amostras de água, já que é um composto que é específico na complexação desse metal (GIROUX et al., 2004); sua constante de complexação em relação a este íon metálico é bem conhecida e o seu valor alto confirma essa especificidade (VANLOOT et al., 2007).

Desse modo, a modificação de polímeros com compostos derivados do ácido salicílico permite o uso desse tipo de material na pré-concentração de metais em nível de traço e na segregação específica de metais (BOUDENNE et al., 2002), sendo este um potencial produto para ser utilizado na remediação de alumínio em água destinadas ao consumo humano.

A modificação de polímeros pela aplicação do processo de irradiação vem tornando-se popular, pois permite alterar as suas propriedades mecânicas sem gerar resíduos. Para a obtenção de um novo produto polimérico por irradiação, capaz de apresentar distintas propriedades físico-químicas, é necessário um estudo preliminar do comportamento do polímero em função dos parâmetros de irradiação (dose absorvida e taxa de dose) (MOURA et al., 2011). 
A radiação ionizante fornece a energia necessária para quebrar ligações covalentes nos compostos e gerar radicais livres, substituindo o uso de iniciadores para a reação de polimerização. Sendo assim, é possível obter copolímeros via enxertia de monômeros com alto grau rendimento a partir do uso de solventes adequados (MOURA et al., 2012).

Nesse penúltimo capítulo é apresentado o processo de obtenção de uma membrana polimérica modificada a partir do processo de copolimerização por irradiação ionizante utilizando filmes de PVC e de PP como polímeros base e o monômero estireno como o material a ser enxertado. Os polímeros cloreto de polivinila (PVC) e polipropileno (PP) são polímeros de baixo custo e recicláveis, por isso são materiais muito empregados na manufatura de objetos de uso geral. O estireno é um monômero encontrado em concentrações baixas em plantas, frutas, vegetais, bebidas e carnes, além disso, sua forma é líquida, oleosa e incolor podendo ser polimerizada facilmente à temperatura ambiente e na presença de oxigênio. Por ser um hidrocarboneto aromático contendo cadeia lateral insaturada, sua molécula polimeriza-se rapidamente na presença de radicais livres - com o grupo vinila que esse composto possui, há a possibilidade de obtenção de grande variedade de materiais plásticos (MANO, 1999).

Uma vez obtido o material polimérico modificado por radiação, um processo químico permite mais um conjunto de modificações até obter um derivado do ácido salicílico. O material assim sintetizado é testado em amostras de água destilada em que foram colocadas distintas concentrações de íons alumínio (amostras padrão) e nas amostras de água natural estudadas nesse trabalho.

\subsection{Objetivos}

O objetivo geral desse trabalho é desenvolver uma membrana seletiva ao alumínio a partir do processo de irradiação ionizante.

Os objetivos específicos são:

- Realizar enxertia polimérica por radiação ionizante e modificar o polímero enxertado via processo químico orgânico;

- Verificar a afinidade e a seletividade ao alumínio a partir da membrana obtida em amostras padronizadas;

- Testar a membrana obtida em amostras de água subterrânea coletadas na região da Represa Billings (em um poço contaminado e nascente). 


\subsection{Materiais e Métodos}

\subsubsection{Preparo da membrana enxertada por radiação ionizante}

Filmes de PP e PVC da marca Goodfellow e Vulcan, respectivamente, com 0,1 $\mathrm{mm}$ de espessura foram lavados em etanol (P.A.) e secos à temperatura ambiente. Em seguida, foram inseridos em frascos de vidro contendo soluções de estireno/n-butanol e estireno/n-octanol (ambas 1:1 v/v).

As soluções foram seladas em frascos de vidro e irradiadas a partir de dois processos: a) radiação gama proveniente de uma fonte de cobalto-60, com taxa de dose de $1,5 \mathrm{~Gy} / \mathrm{h}$ e dose total de $50 \mathrm{kGy}$ à temperatura ambiente; b) radiação proveniente de uma fonte de feixe de elétrons utilizando o Acelerador Dynamitron Job188 de 1,5 MeV e potência do feixe de $37,5 \mathrm{~kW}$, numa dose de $50 \mathrm{kGy}$ e taxa de dose de 2,2 kGy/s (detalhes do processo ver item 4.2.1.2).

Após o processo de irradiação, as amostras foram imersas em tolueno (Merck), e lavadas com etanol várias vezes sob temperatura ambiente e secas em estufa sob vácuo à $50{ }^{\circ} \mathrm{C}$.

As amostras enxertadas com estireno foram analisadas por gravimetria para determinação do rendimento de enxerto, os valores finais foram calculados pela média de uma série de três medições.

\subsubsection{Modificação química do polímero enxertado}

O processo químico orgânico de modificação da membrana enxertada com estireno compreendeu em três passos:

1) Acilação de Friedel-Crafts;

2) Acoplamento com 2-metilanisola e;

3) O-desmetilação oxidativa.

No primeiro passo, as amostras de PVC e PP foram submetidas à ação de acilação, ou seja, a introdução de um grupo acila no polímero. O agente aplicado foi o cloreto de acetila em conjunto com o óxido de zinco $(2 \mathrm{mmol})$ durante 5 minutos em temperatura ambiente, de acordo com o método de Sarvari \& Sharghi (2004) para a 
copolimerização ${ }^{1}$ do ácido salicílico. Após a reação, as amostras foram lavadas com ácido clorídrico (1:1), metanol e água destilada. Em seguida, as amostras foram submetidas à oxidação dada pela solução de permanganato de potássio $(15 \mathrm{mmol})$, passando por solução aquosa de hidróxido de sódio $(0,14 \mathrm{mmol})$ durante 16 horas em temperatura ambiente. Após esse período, as amostras foram lavadas com água destilada.

De acordo com o método de Boudenne et al., (2002) para conversão final dos ácidos carboxílicos em cloretos de acila, o reagente cloreto de tionila $\left(\mathrm{SOCl}_{2}\right)$ foi utilizado sob agitação e temperatura controlada $\left(60^{\circ} \mathrm{C}\right)$, durante 5 minutos. Nesta etapa, a membrana de PVC foi degradada devido à ação agressiva dos agentes químicos. Apenas as amostras de PP prosseguiram nas demais etapas.

No segundo passo houve o acoplamento do reagente 2-metilanisola na presença de óxido de zinco ( 2 mmolar), nas condições de temperatura ambiente e agitação intermitente durante 60 minutos; o 2-metilanisola é ao mesmo tempo reagente e solvente. Após essa reação, as amostras foram lavadas várias vezes com água destilada e metanol e novamente oxidadas na mesma solução de permanganato de potássio descrita acima. $\mathrm{O}$ resíduo dessa oxidação, após diversas lavagens do material com água destilada, é o dióxido de manganês $\left(\mathrm{MnO}_{2}\right)$. Sua remoção foi promovida pela imersão do material polimérico em solução aquosa de ácido clorídrico (1:1), metanol e água destilada.

Finalmente, o último passo foi baseado no método descrito por Kende et al. (1976), onde as amostras secas foram imersas em solução de cloreto de alumínio anidro e tolueno ( $2 \mathrm{mmol})$, sob agitação e temperatura ambiente durante 8 horas. Após esse período, as amostras foram lavadas com ácido clorídrico (1:1), água destilada e metanol. Essas etapas estão ilustradas no fluxograma da FIG. 6.1.

\subsubsection{Espectroscopia no Infravermelho por Transformada de Fourrier (FTIR)}

As amostras de filmes de PP enxertados foram analisadas por espectroscopia no Infravermelho (FTIR), utilizando o espectrômetro de FTIR modelo 100 da PerkinElmer. Essa técnica permitiu obter os espectros de infravermelho na faixa de freqüência de 4000 a $400 \mathrm{~cm}^{-1}$ (infravermelho médio), onde o sinal obtido nesse intervalo de freqüência é transformado a partir da sua aquisição em um interferômetro (transformada de Fourier). Os

\footnotetext{
${ }^{1}$ Copolimerização (CALLISTER, 2002): processo de obtenção de polímeros que contém um ou mais tipos de meros (menor unidade formadora de um polímero) cuja origem está na aplicação de um ou mais tipos de monômeros. Essas unidades de meros diferentes podem estar presentes aleatoriamente (copolímero aleatório), alternados, aglomerados em blocos ao longo da cadeia (copolímero bloco) ou ainda como ramificações em um polímero base (copolímeros por enxerto ou copolímeros enxertados).
} 
espectros das amostras poliméricas foram obtidos em modo de ATR (Reflectância Total Atenuada).

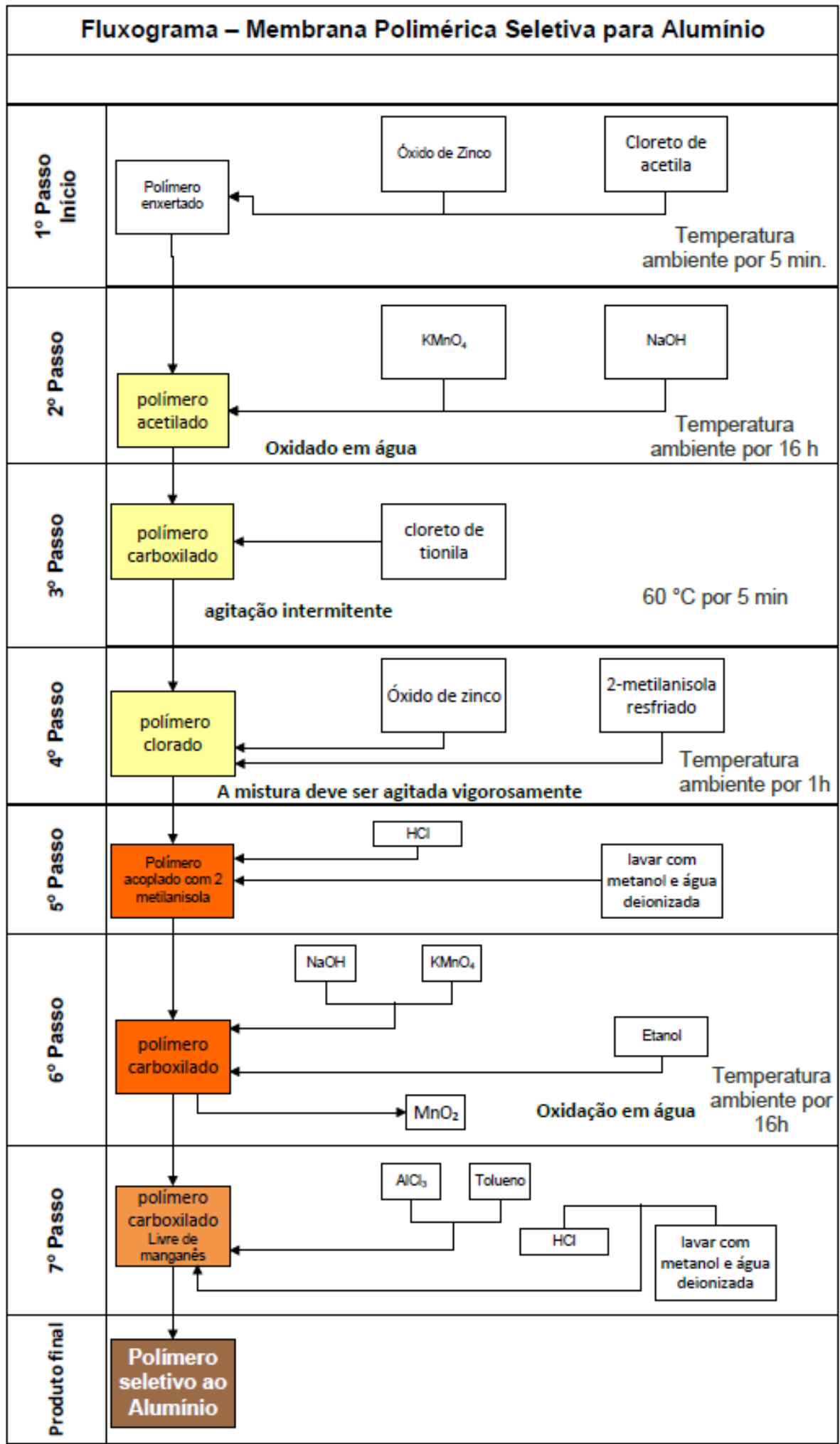

FIGURA 6.1 - Fluxograma do polímero seletivo para a espécie química alumínio. 


\subsubsection{Análise morfológica da membrana}

A morfologia da membrana foi analisada por microscopia eletrônica de varredura (MEV), onde foi utilizado um microscópio eletrônico de varredura da marca Hitachi modelo TM3000. As micrografias foram obtidas da superfície da amostra isenta de qualquer pré-tratamento. As imagens foram formadas a partir da interação com elétrons secundários.

\subsubsection{Testes de avaliação da membrana seletiva ao alumínio}

\subsubsection{Sorção ${ }^{2}$ de alumínio em $\mathrm{pH}$ ideal e agentes interferentes}

O poder de sorção do alumínio foi verificado em soluções de distintos valores de $\mathrm{pH}(2,5 ; 5,0 ; 6,0 ; 7,0$ e 8,0) usando as soluções tampão acetato de sódio/ácido acético de sódio $(0,1 \mathrm{M})$ e cloreto de amônio/hidróxido de amônio $(0,1 \mathrm{M})$. A curva da cinética de sorção foi apresentada a partir de amostragens nos tempos de 5, 10, 15, 20, 25, 30 e 60 minutos.

Para avaliação de agentes interferentes, Zn e Cd são adicionados à solução em concentração próxima ao de alumínio (7 ppm). A avaliação dos interferentes no processo de seletividade da membrana ao alumínio foi apresentada graficamente em amostragens nos mesmos valores de tempo acima descritos.

\subsubsection{Determinação da capacidade de absorção do alumínio}

A capacidade de sorção do alumínio é determinada pelo método descontínuo de uma massa seca específica - membrana seca. A massa é imersa numa solução padrão de alumínio com uma concentração e volume específico (HELFFERISH, 1962).

A membrana seca foi então adicionada a uma solução aquosa contendo uma determinada concentração de alumínio, permanecendo por toda a noite em balão volumétrico tampado.

Depois deste período, a membrana foi retirada do meio, lavada com água destilada, seca e pesada para verificar alterações de massa; o alumínio da membrana foi removido com solução de ácido clorídrico 1 M. A solução contendo alumínio foi acondicionada em um balão volumétrico para a determinação do alumínio por UV-vis (descrição no item 4.2.2.3.1). Em seguida a membrana foi colocada em estufa a vácuo

\footnotetext{
${ }^{2}$ Sorção (BARIZON, 2004) refere-se à ação de absorção e adsorção ocorrendo simultaneamente.
} 
numa temperatura equivalente a $30{ }^{\circ} \mathrm{C}$ para sua secagem, em seguida foi pesada, estando assim pronta para a sua reutilização em outras amostras.

A capacidade de retenção aos íons alumínio da membrana sintetizada $\left(\mathrm{Q}_{\mathrm{Al}}\right)$ foi determinada a partir da concentração total de alumínio determinada por UV-Vis e relacionada com o peso unitário em gramas de membrana.

\subsubsection{Teste da membrana seletiva ao alumínio em amostras de água natural}

\subsubsection{Coleta de amostras}

As amostras de água de poço (P9) e nascente, com concentrações de alumínio determinadas como descrição no item 5.4.6, foram submetidas ao teste de viabilidade com a membrana seletiva (item 6.3.5).

\subsubsection{Pré-concentração dos íons alumínio (Al) utilizando a membrana seletiva}

Apenas as membranas poliméricas de PP enxertadas foram utilizadas no teste de captação ao alumínio. Para quantificar o alumínio pela técnica de UV-vis foi necessário concentrar esses íons através do uso da membrana seletiva, já que o limite de detecção da técnica que é de $0,04 \mathrm{mg} / 1$ de Al. Sendo assim, foi utilizado 1 litro de amostra para cada ponto coletado.

Após 2 horas de concentração dos íons na membrana, lavou-se o polímero com $2 \mathrm{ml}$ solução de ácido clorídrico $1 \mathrm{M}$ para que todo o alumínio retido na membrana se solubilizasse. O líquido dessa dissolução foi transferido quantitativamente para um balão volumétrico de $10 \mathrm{ml}$, estando aí todo o alumínio concentrado de 1 litro de amostra de água natural.

A metodologia de análise seguiu aquela já descrita no item 4.2.2.3.1.

\subsection{Resultados e Discussão}

\subsubsection{Síntese da membrana seletiva ao alumínio}

A TAB. 6.1 mostra o grau de enxertia das amostras testadas. Os resultados estão de acordo com o tipo de polímero e a composição do meio de enxertia. O processo de enxertia por radiação gama promoveu alto rendimento, que é devido tanto à baixa taxa de dose com também tipo e concentração do solvente. Em termos de aspecto visual, as 
membranas que tiverem menor grau de enxertia resultaram em amostras planas e lisas; membranas com alto rendimento na enxertia tiveram uma aparência enrugada e franzida.

TABELA 6.1 - Processo de enxertia com estireno em amostras de PP.

\begin{tabular}{ccc}
\hline Amostras & Enxertia - média & Enxertia (\%) \\
\hline PP-1 & Estireno-n-butanol 1:1 & $91,5(0,6)$ \\
PP-2 & Estireno-n-octanol 1:1 & $77,3(4,3)$ \\
PP-3 & Estireno-n-octanol 1:3 & $27,1(5,5)$ \\
\hline
\end{tabular}

Os tipos diferentes de amostras (PP-1, PP-2 e PP-3) foram submetidos ao primeiro passo de modificação química e apresentaram resultados distintos com relação ao rendimento da reação. Esta etapa no processo é a principal, pois é a que determina a quantidade de grupos responsáveis pela seletividade ao alumínio da membrana. O bom desempenho nesse passo depende do catalisador e do reagente de acilação que irá promover o ataque do anel aromático das amostras.

Quando a reação é realizada com uma concentração de óxido de zinco $(\mathrm{ZnO})$ inferior a $2 \mathrm{mmol}$ (relacionada com a concentração molar de estireno enxertado no substrato de polímero), o rendimento da reação é baixo (cerca de 9\% para o PP enxertado). $\mathrm{O}$ uso de uma concentração de 3 a $5 \mathrm{mmol}$ deste catalisador resulta em rendimento superior a $20 \%$ para o PP enxertado. O aumento do rendimento dessa reação está condicionado ao pré-tratamento das amostras de PP enxertadas, que é o inchamento prévio do polímero com solventes orgânicos (tolueno e clorofórmio), já que não se observa o intumescimento dessas amostras quando se utiliza somente cloreto de acetila.

A reação de acilação aplicada às amostras quando são pré-imersas em 1 hora no tolueno resultaram rendimentos cerca de 60\%; quando as amostras foram pré-imersas em clorofórmio neste mesmo período, o rendimento da reação atingiu até 84 \%.

Analisando os espectros de ATR-FTIR da FIG. 6.2, o primeiro espectro mostra as informações moleculares da membrana inicial (após o processo de irradiação gama). As seguintes bandas de absorção são características do estireno enxertado: em $690 \mathrm{~cm}^{-1}$ (corresponde às vibrações fora do plano das ligações C-H do anel aromático); em $750 \mathrm{~cm}^{-1}$ (plano de flexão fora do plano dos átomos de $\mathrm{H}$ no anel aromático); em $1.491 \mathrm{~cm}^{-1} \mathrm{e} \mathrm{em}$ $1.595 \mathrm{~cm}^{-1}$ correspondem à deformação das ligações de carbono $(\mathrm{C}=\mathrm{C})$ na cadeia que contém o estireno. 
O segundo espectro representa o processo de Friedel-Crafts, onde as bandas de absorção estão as localizadas em $1.196 \mathrm{~cm}^{-1}$ e a $1.260 \mathrm{~cm}^{-1}$ (grupo aril-cetonas) e em $1.337 \mathrm{~cm}^{-1}$, que representa a deformação de vibração da ligação $\mathrm{CO}-\mathrm{CH}_{3}$.

O terceiro espectro refere-se ao acoplamento com 2-metilanisola ao substrato polimérico nas bandas de absorção em $1.122 \mathrm{~cm}^{-1}$ (vibração de ligação $\mathrm{C}-\mathrm{O}$ no grupo metoxi) e em $1.015 \mathrm{~cm}^{-1}$ (banda de deformação de anéis fenil tri-substituído).

O último espectro mostra a etapa final do processo de modificação química das membranas de polipropileno. Houve o desaparecimento da banda de absorção em 1.122 $\mathrm{cm}^{-1}$, devido à desproteção do grupo metoxi.
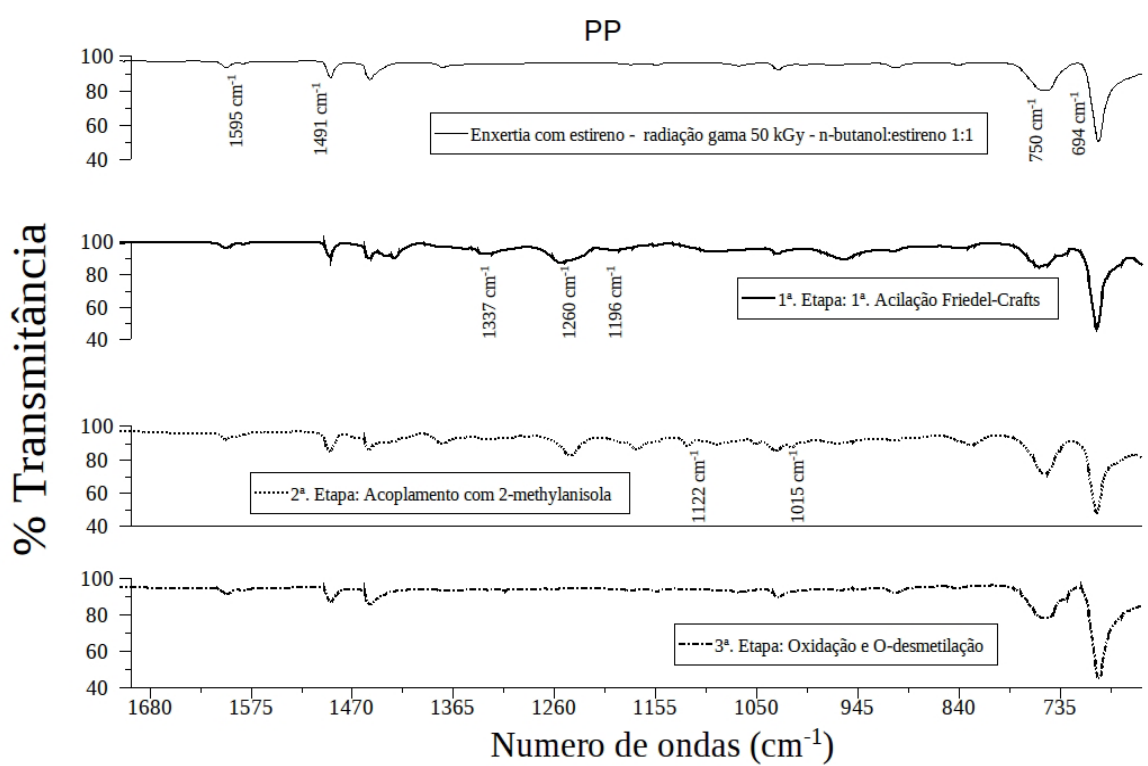

FIGURA 6.2 - Espectros do PP enxertado em cada etapa de modificação química.

As três figuras a seguir mostram as micrografias eletrônicas de varredura das amostras de PP somente enxertada e de PP enxertada e modificada quimicamente. Estes resultados mostram superfície lisa para a membrana com elevado grau de enxertia (FIG.6.3) e esta morfologia não foi alterada com o processo de modificação química (FIG.6.4). No entanto, fissuras e trincas aparecem em amostra com baixo grau de enxertia (FIG.6.5) e sugere que o processo químico é mais agressivo neste tipo de amostra. 


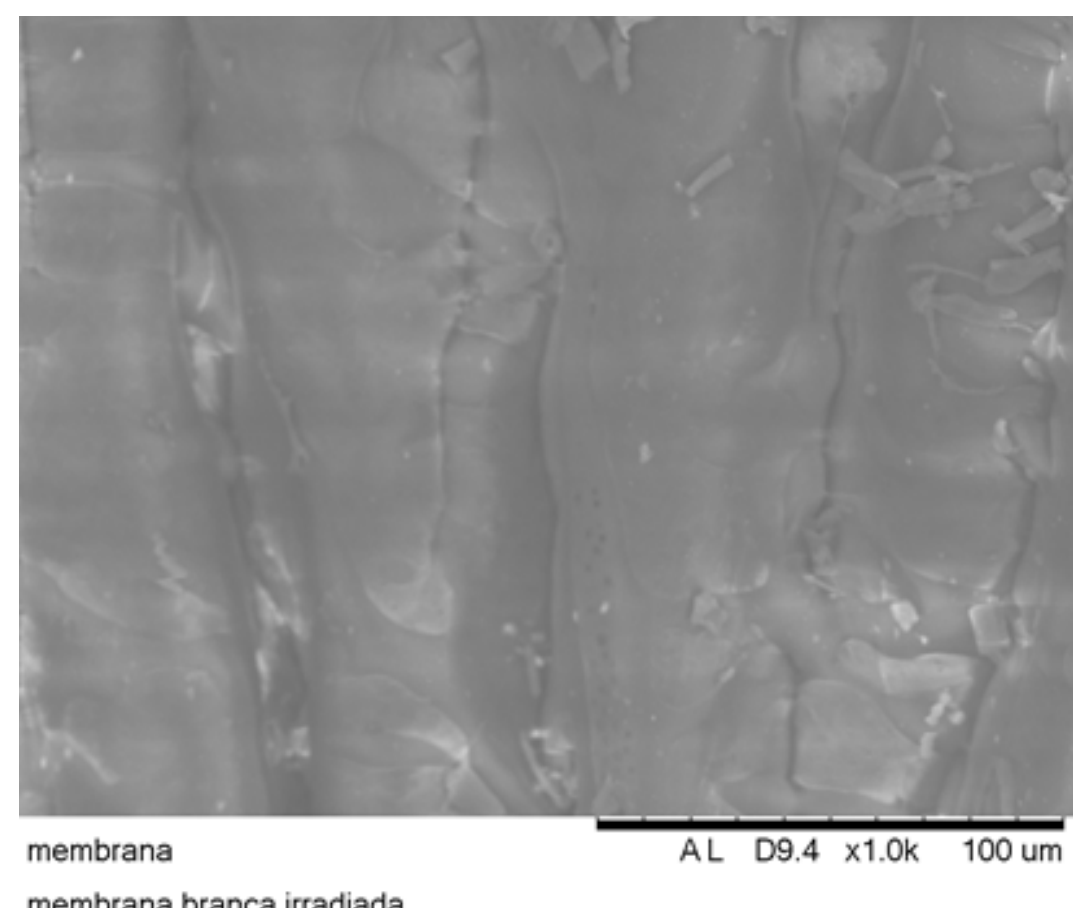

membrana branca irradiada

FIGURA 6.3 - Micrografia eletrônica de varredura da amostra de PP enxertada com estireno com elevado grau de enxertia (PP-1).

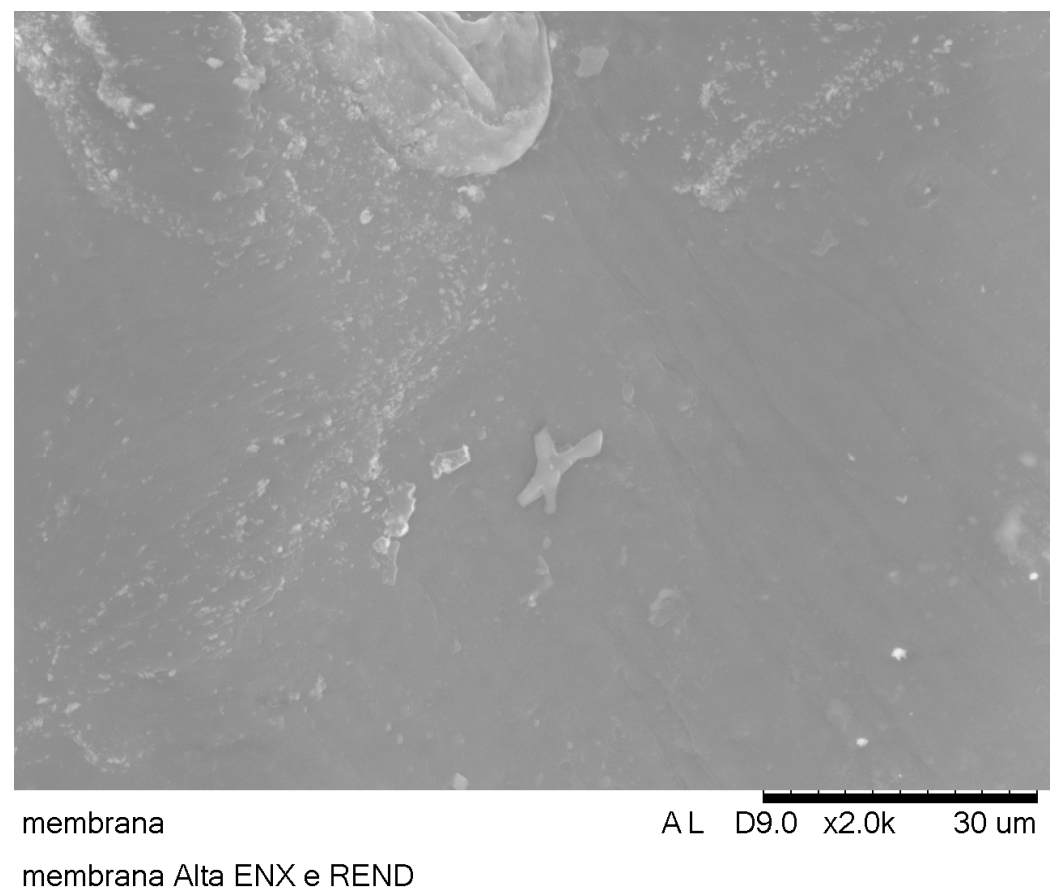

FIGURA 6.4 - Micrografia eletrônica de varredura da amostra de PP enxertada com estireno com elevado grau de enxertia e quimicamente modificada (PP-1). 


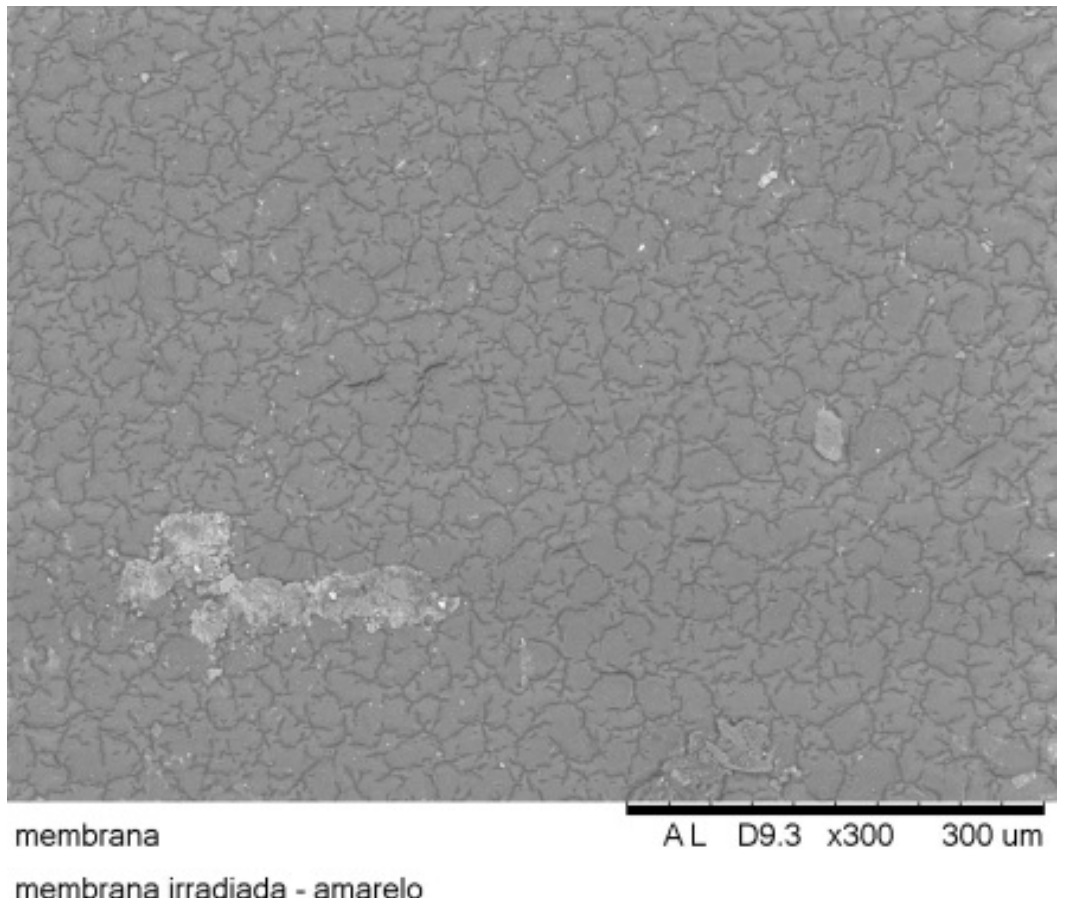

FIGURA 6.5 - Micrografia eletrônica de varredura da amostra de PP enxertada com estireno em baixo grau de enxertia e quimicamente modificada (PP-2).

A modificação química aplicada à membrana de polipropileno neste trabalho foi menos agressiva que a modificação química descrita por Boudenne et al., (2002). A maioria das reações foi realizada à temperatura ambiente e a utilização de solventes orgânicos foi minimizada, já que os substratos de polímeros não tinham passado por um tratamento prévio para elevar a resistência mecânica, como o processo de reticulação polimérica $^{3}$. Nas condições experimentais efetuadas neste trabalho, a matriz de PP conservou a forma original de filme no resultado final, como mostra a FIG. 6.6.

3 Reticulação polimérica (STEVENS, 1999) é um processo que ocorre quando cadeias poliméricas lineares ou ramificadas são interligadas por ligações covalentes, um processo conhecido como crosslinking ou ligação cruzada - ligações entre moléculas não ramificadas produzindo polímeros tridimensionais com alta massa molar. Com o aumento da reticulação, a estrutura molecular torna-se mais rígida. A vulcanização da borracha é um exemplo de ligação cruzada. 


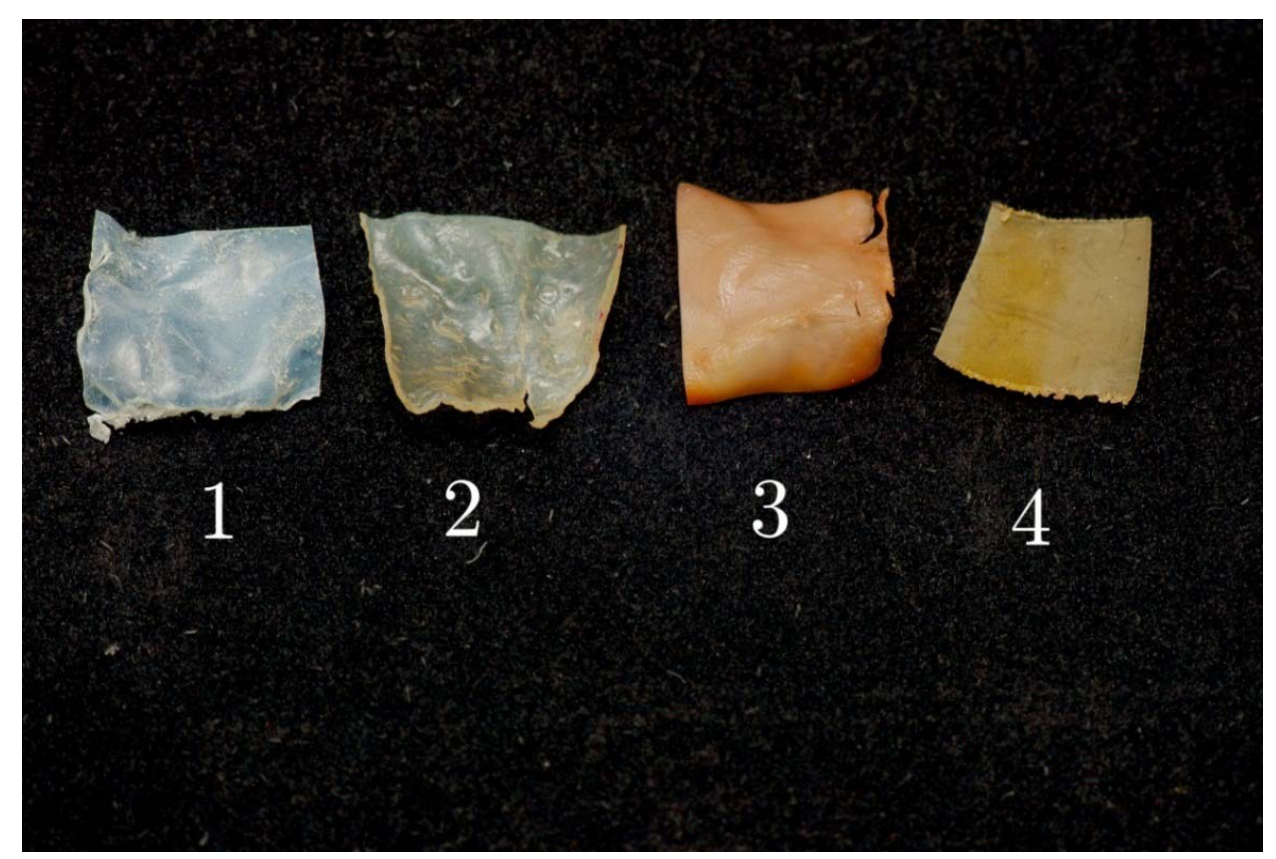

FIGURA 6.6 - (1) PP enxertado com estireno por irradiação (alto grau de enxertia); (2) PP enxertado (alto grau de enxertia) e modificado quimicamente (baixo rendimento no processo químico); (3) PP enxertado (alto grau de enxertia) e com alto rendimento na etapa de modificação química; (4) PP enxertado (baixo grau de enxertia) e com alto rendimento na etapa de modificação química.

A TAB. 6.2 mostra os resultados das capacidades de sorção ao alumínio pelas amostras de membrana de PP enxertada com estireno e modificada quimicamente obtidas com rendimentos distintos de salicilação ${ }^{4}$. A amostra PP-1a teve elevado grau de enxertia e elevado grau de salicilação, isto explica sua elevada capacidade de retenção de alumínio.

TABELA 6.2 - Capacidade de captação de alumínio com amostras de membranas modificadas

\begin{tabular}{ccc}
\hline $\begin{array}{c}\text { Amostra de membrana } \\
\text { Modificada }\end{array}$ & Salicilação (\%) & $\begin{array}{c}\text { Capacidade de absorção ao } \\
\text { alumínio (mg/l) }\end{array}$ \\
\hline PP-1-a & 66,8 & 7,0 \\
PP-1-b & 7,60 & 0,8 \\
\hline
\end{tabular}

\footnotetext{
${ }^{4}$ Salicilação (adaptado de VANLOOT, 2007) processo químico que transforma o substrato em derivado do ácido salicílico.
} 


\subsubsection{Cinética da sorção do alumínio}

O comportamento cinético do alumínio foi um exemplo clássico da sorção. Inicialmente, o processo se caracterizou pela elevada sorção ao metal alumínio e após um determinado tempo, sua intensidade de retenção foi diminuindo até atingir a saturação. A FIG. 6.7 mostra este comportamento cinético nos distintos valores de $\mathrm{pH}$ estudados. Esses resultados mostram que o $\mathrm{pH}=7,0$ foi o melhor valor de $\mathrm{pH}$ para retenção do alumínio no meio utilizado.

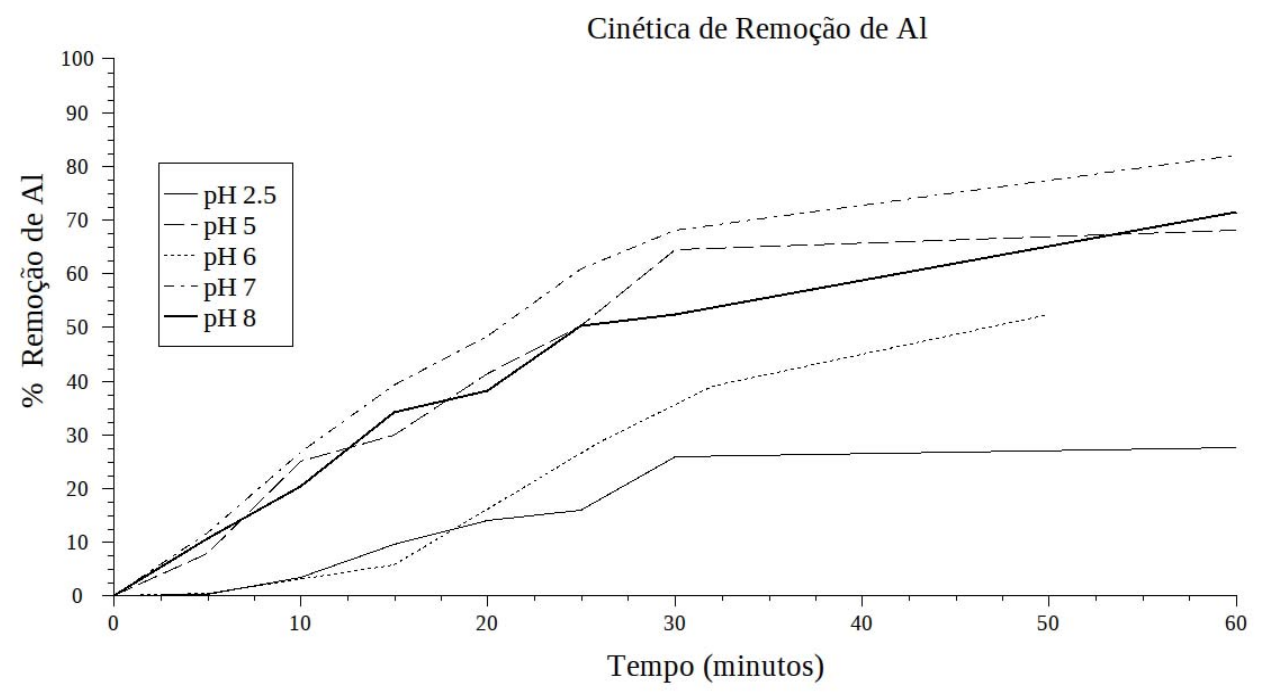

FIGURA 6.7 - Remoção de alumínio a partir de soluções líquidas em distintos valores de pH em função do tempo de sorção.

\subsubsection{Teste de seletividade ao alumínio}

A seletividade das membranas modificadas de alumínio foi verificada e os resultados estão na FIG. 6.8. Todos os resultados mostram o mesmo comportamento cinético, mesmo quando a membrana está em contato com soluções que contém as mesmas concentrações de $\mathrm{Al}$ e $\mathrm{Zn}$ ou $\mathrm{Cd}$ e $\mathrm{Al}$, em $\mathrm{pH}=7,0$. Estes resultados sugerem uma cinética única. A sorção de alumínio apresenta valores superiores a $80 \%$ após1 hora de contato. 


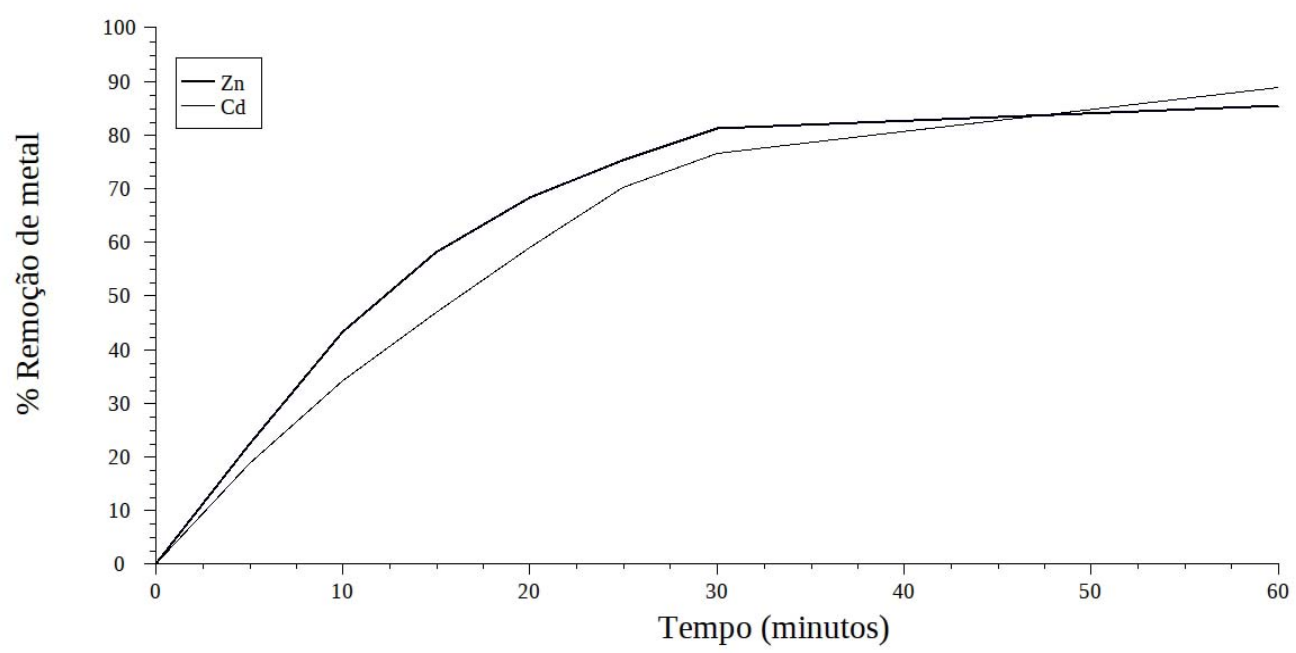

FIGURA 6.8 - Efeito da sorção de alumínio na solução contendo como interferentes os íons $\mathrm{Zn}^{2+}$ e $\mathrm{Cd}^{2+}$.

Os resultados referentes à retenção de alumínio em águas naturais coletadas nos poços estudados nesta tese a partir do seu contato com a membrana modificada estão apresentados na TAB. 6.3. Para cada amostra de água, os teores de alumínio são distintos e muitos próximos dos valores apresentado na TAB. 5.7. Estes resultados sugerem que as membranas de PP enxertadas com estireno e saliciladas são eficazes na remoção de alumínio na água e pode ser aplicada como material remediador seletivo.

TABELA 6.3 - Captação de alumínio a partir de amostras de águas naturais.

\begin{tabular}{ccc}
\hline Amostra de água & $\begin{array}{c}\text { Tipo de membrana } \\
\text { modificada }\end{array}$ & Absorção de Al - mg/l \\
\hline Nascente & PP-1-a & 0,0118 \\
P9 & PP-1-b & 1,9214 \\
\hline
\end{tabular}




\subsection{Conclusão}

O processo de obtenção de membranas de PP enxertadas com estireno por irradiação e quimicamente modificadas foi desenvolvido em três etapas básicas: a) acilação de Friedel-Crafts, b) acoplamento com 2-metilanisola e c) O-desmetilação oxidativa. Esta última é a etapa que fornece a modificação química necessária para conferir a característica de seletividade ao alumínio. As etapas químicas foram efetivas na modificação da membrana, sendo o produto final um derivado salicilado. O processo de modificação química foi adequado de modo a preservar a estrutura física inicial da membrana.

As membranas poliméricas enxertadas e quimicamente modificadas mostraram eficácia na remoção de alumínio da água, principalmente em $\mathrm{pH}$ igual a 7,0. As membranas apresentaram seletividade frente às espécies interferentes analisadas: íons $\mathrm{Zn}^{2+}$ e $\mathrm{Cd}^{2+}$.

Embora, a remoção de alumínio pelas membranas sintetizadas neste trabalho foi efetiva nas amostras de águas naturais, são necessários mais ensaios para a popularização do seu uso em água potável. 


\section{REFERÊNCIAS BIBLIOGRÁFICAS}

APOSHIAN, H. V., MAIORINOA, R. M., GONZALEZ-RAMIREZ, D., ZUNIGACHARLES, M., XUA, Z., HURLBUTD, K.M., JUNCO-MUNOZE, P., DARTD, R. C., APOSHIAN, M. M. Mobilization of heavy metals by newer, therapeutically useful chelating agents. Toxicology. 97: 23-38, 1995.

BARIZON, R.R.M. Sorção e transporte de pesticidas sob condições de não-equilibrio. Tese de Doutorado. Piracicaba, São Paulo, Brasil. 107p, 2004.

BOUDENNE, J. L., BOUSSETTA, S., BRACH-PAPA, C., BRANGER, C., MARGAILLAN, A., THERAULAZ, F. Modification of Poly(styrene-co-divinylbenzene) Resin by Grafting on an Aluminium Selective Ligand. Polym. Int. 51,1050-1057, 2002.

CALLISTER JR, W. D. Ciência e Engenharia de Materiais: Uma Introdução. $5^{\mathrm{a} e d ., ~ R i o ~}$ de Janeiro, LTC, 2002.

GIROUX, S., AURY, S., RUBINI, P., PARANT, S., DESMURS, J.R., DURY, M. A spectroscopic investigation of the complexing ability of catecholate or salicylate derivatives towards aluminium(III). Polyhedron. V. 23(15), 30, 2393-2404, 2004.

HELFFERISH, F. Ion Exchange, McGraw-Hill Book Co. Inc., NY, USA, 1962.

ISA, I. MD., SOHAIMI, N. M., HASHIM, N., KAMARI, A., MOHAMED, A., AHMAD, M., GHANI, S. A., SUYANTA. Determination of Salicylate ion by Potentiometric Membrane Electrode based on Zinc Aluminium Layered Double Hydroxides-4 (2,4dichlorophenoxy) Butyrate Nanocomposites. Int. J. Electrochem. Sci., v. 8, p.2112 2121, 2013.

KENDE, A.S., TSAY, Y-G., MILLS, J.E. Total Synthesis of (f)-Daunomycinone and (f)Carminomycinone. Journal Am. Chem. Society, 98(7), pp.1967-1969, 1976.

KHAN, S., KAZI, T.G., BAIG, J.A., KOLACHI, N.F., AFRIDI, H.I., SHAH, A.Q., KANDHRO, G.A., KUMAR, S. Separation and Preconcentration of Trace Amounts of Aluminum Ions in Surface Water Samples Using Different Analytical Techniques. Talanta 80, 158-162, 2009.

MANO, E. B.; MENDES, L. C. Introdução a polímeros. 2.ed. São Paulo: E.Blücher, 191 p, 1999.

MOURA, E., MANZOLI, J.E., GERALDO, A.B.C. Effects of solvent polarity on mutual styrene grafting onto polypropylene by electron beam irradiation. Rad. Phys. Chem. 81(9), 1309-1313, 2012. 
MOURA, E., SOMESSARI, E.S.R., SILVEIRA, C.G., PAES, H.A., SOUZA, C.A., FERNANDES, W., MANZOLI, J.E., GERALDO, A.B.C. Influence of physical parameters on mutual polymer grafting by electron beam irradiation. Rad. Phys. Chem. 80(2), 175$181,2011$.

SARVARI, M.H. \& SHARGHI, H. Reactions on a Solid Surface. A Simple, Economical and Efficient Friedel-Crafts Acylation Reaction over Zinc Oxide (ZnO) as a New Catalyst, Journal Org. Chem., 69(20), pp.6953-6956, 2004.

STEVENS, M.P. Polymer chemistry: an introduction 3rd ed. Oxford University Press, New York, 1: 3, 34p, 1999.

TANDY, S., BOSSART, K., MUELLER, R., RITSCHEL, J., HAUSER, L., SCHULIN, R., NOWACK, B. Extraction of heavy metals from soils using biodegradable chelating agents. Environmental Science Technology, v.38, p.937-944, 2004.

VANLOOT, P., BOUDENNE, J.-L., BRACH-PAPA, C., SERGENT, M., COULOMBA, B. 2007., An experimental design to optimize the flow extraction parameters for the selective removal of $\mathrm{Fe}(\mathrm{III})$ and $\mathrm{Al}(\mathrm{III})$ in aqueous samples using salicylic acid grafted on Amberlite XAD-4 and final determination by GF-AAS. Journal of Hazardous Materials, v. 147, p.463-470, 2007. 


\section{CONSIDERAÇÕES FINAIS}

A qualidade da água é influenciada pela formação geológica do solo, aspectos construtivos do poço, pela localização do poço e principalmente por ações antropogênicas no local. Com base na descrição técnica-analítica dos capítulos 2, 4 e 5, as amostras de água dos poços estudados apresentam uma fração orgânica de matriz complexa, que somente pode ser degradada por uma técnica de digestão prévia à análise química quantitativa e que neste trabalho foi a aplicação de uma metodologia de digestão por radiação ionizante. Todas as questões levantadas neste trabalho sugerem que o próprio elemento em estudo pode estar tão intimamente ligado à matriz orgânica complexa que é possível que não seja quantificado de forma total, o que gera baixa fidedignidade nos resultados até mesmo por técnicas como o ICP-OES.

A radiação ionizante também foi aplicada no desenvolvimento de uma membrana polimérica seletiva ao alumínio, sendo esta a proposta de um novo produto que poderá ser aplicado na remediação das águas estudadas. Embora a membrana desenvolvida tenha sido obtida em quantidades laboratoriais, é factível o dimensionamento da produção da membrana para o uso nas estações de tratamento de água para o abastecimento público, pois parte da água da represa Billings também é utilizada para este fim.

\subsection{Perspectivas Futuras}

- Aplicar a técnica de digestão por radiação ionizante como pré-tratamento amostral e consequente otimização da detecção analítica em novas amostras de água natural, principalmente no diagnóstico da sua potabilidade;

- Estudar o sedimento dos poços e solo da região;

- Estudo da obtenção da membrana seletiva ao alumínio tendo como base outros polímeros recicláveis.

- Incentivar o monitoramento contínuo das águas da represa Billings e dos poços da região junto aos órgãos governamentais, não governamentais e comunidade local;

- Disseminar o conhecimento sobre boa qualidade da água potável perante a comunidade local (incluindo o estudo de técnicas de extração da água e tratamento de água em reservatórios de transição). 
ANEXO A - FICHAS DE COLETA 


\begin{tabular}{|l|l|}
\hline Responsável do Projeto: Renata & No. Coleta: 01 \\
\cline { 1 - 1 } Matriz (material a ser analisado): água & Data/hora da coleta: agosto \\
\cline { 1 - 2 } Análise requerida: Metais & Nível d'água: $11,92 \mathrm{~m}$ \\
\hline Ponto de estudo: P1 & UTM_Y (m) 7370388,00 \\
\hline Localização: UTM_X (m) 332050,00 & $\begin{array}{l}\text { Chuva no momento da coleta: } \\
(\mathrm{x}) \text { sim ( ) não ( ) não aplicável }\end{array}$ \\
\cline { 1 - 2 } $\begin{array}{l}\text { Chuva nas últimas 48 horas: } \\
\text { x ) sim ( ) não ( ) não aplicável }\end{array}$ & Temperatura ambiente: $13,4{ }^{\circ} \mathrm{C}$ \\
\hline Profundidade: $16,43 \mathrm{~m}$ & \\
\hline Diâmetro: $1,61 \mathrm{~m}$ &
\end{tabular}

\begin{tabular}{|l|l|}
\hline Responsável do Projeto: Renata & No. Coleta: 01 \\
\hline Matriz (material a ser analisado): água & Data/hora da coleta: agosto \\
\hline Análise requerida: Metais & Nível d'água: N.A. \\
\hline Ponto de estudo: P4 & UTM_Y (m) 7368929,00 \\
\hline Localização: UTM_X (m) 332189,00 & $\begin{array}{l}\text { Chuva no momento da coleta: } \\
(\quad) \text { sim ( } \text { x ) não ( ) não aplicável }\end{array}$ \\
\hline $\begin{array}{l}\text { Chuva nas últimas 48 horas: } \\
(\text { x ) sim ( ) não ( ) não aplicável }\end{array}$ & Temperatura ambiente: $19,7^{\circ} \mathrm{C}$ \\
\hline Profundidade: 55,0 m & \\
\hline Diâmetro: N.A. &
\end{tabular}

\begin{tabular}{|l|l|}
\hline Responsável do Projeto: Renata & No. Coleta: 01 \\
\hline Matriz (material a ser analisado): água & Data/hora da coleta: agosto \\
\cline { 1 - 2 } Análise requerida: Metais & Nível d'água: $17,73 \mathrm{~m}$ \\
\hline Ponto de estudo: P8 & UTM_Y (m) 7366588,00 \\
\hline Localização: UTM_X (m) 333841,00 & $\begin{array}{l}\text { Chuva no momento da coleta: } \\
(\mathrm{x}) \text { sim ( ) não ( ) não aplicável }\end{array}$ \\
\hline $\begin{array}{l}\text { Chuva nas últimas 48 horas: } \\
\text { x ) sim ( ) não ( ) não aplicável }\end{array}$ & Temperatura ambiente: $13,4{ }^{\circ} \mathrm{C}$ \\
\hline Profundidade: $19,40 \mathrm{~m}$ & \\
\hline Diâmetro: $1,0 \mathrm{~m}$ &
\end{tabular}

\begin{tabular}{|l|l|}
\hline Responsável do Projeto: Renata & No. Coleta: 01 \\
\hline Matriz (material a ser analisado): água & Data/hora da coleta: agosto \\
\cline { 1 - 2 } Análise requerida: Metais & Nível d'água: 5,30 m \\
\hline Ponto de estudo: P9 & UTM_Y (m) 7366892,00 \\
\hline Localização: UTM_X (m)334172,00 & $\begin{array}{l}\text { Chuva no momento da coleta: } \\
(\quad) \text { sim ( x ) não ( ) não aplicável }\end{array}$ \\
\hline $\begin{array}{l}\text { Chuva nas últimas 48 horas: } \\
(\quad \text { sim ( x ) não ( ) não aplicável }\end{array}$ & Temperatura ambiente: $27,1^{\circ} \mathrm{C}$ \\
\hline Profundidade: $9,36 \mathrm{~m}$ & \\
\hline Diâmetro: $1,0 \mathrm{~m}$ &
\end{tabular}




\begin{tabular}{|l|l|}
\hline Responsável do Projeto: Renata & No. Coleta: 01 \\
\hline Matriz (material a ser analisado): água & Data/hora da coleta: agosto \\
\hline Análise requerida: Metais & Nível d'água: N.A. \\
\hline Ponto de estudo: nascente & UTM_Y (m) 7366622,68 \\
\hline Localização: UTM_X (m) 333908,06 & $\begin{array}{l}\text { Chuva no momento da coleta: } \\
(\quad) \text { sim (x ) não ( ) não aplicável }\end{array}$ \\
\hline $\begin{array}{l}\text { Chuva nas últimas 48 horas: } \\
(\quad \text { sim ( x ) não ( ) não aplicável }\end{array}$ & Temperatura ambiente: $27,1^{\circ} \mathrm{C}$ \\
\hline Profundidade: N.A. & \\
\hline Diâmetro: N.A. &
\end{tabular}

\begin{tabular}{|l|l|}
\hline Responsável do Projeto: Renata & No. Coleta: 01 \\
\hline Matriz (material a ser analisado): água & Data/hora da coleta: agosto \\
\hline Análise requerida: Metais & Nível d'água: N.A \\
\hline Ponto de estudo: represa Billings & $\begin{array}{l}\text { UTM_Y (m) } \\
7367040,00\end{array}$ \\
\hline $\begin{array}{l}\text { Localização: UTM_X (m) } \\
334276,00\end{array}$ & $\begin{array}{l}\text { Chuva no momento da coleta: } \\
(\quad) \text { sim ( x ) não ( ) não aplicável }\end{array}$ \\
\hline $\begin{array}{l}\text { Chuva nas últimas 48 horas: } \\
\text { ( ) sim ( x ) não ( ) não aplicável }\end{array}$ & Temperatura ambiente: $29,6{ }^{\circ} \mathrm{C}$ \\
\hline Profundidade: & \\
\hline Diâmetro: & \\
\hline
\end{tabular}




\begin{tabular}{|l|l|}
\hline Responsável do Projeto: Renata & No. Coleta: 02 \\
\hline Matriz (material a ser analisado): água & Data/hora da coleta: $18 / 10 / 11$ as 9h \\
\hline Análise requerida: Metais & Nível d'água: $12,0 \mathrm{~m}$ \\
\hline Ponto de estudo: P1 & UTM_Y (m) 7370388,00 \\
\hline Localização: UTM X (m) 332050,00 & $\begin{array}{l}\text { Chuva no momento da coleta: } \\
(\quad) \text { sim ( } \text { ) não ( ) não aplicável }\end{array}$ \\
\hline $\begin{array}{l}\text { Chuva nas últimas 48 horas: } \\
(\quad \text { sim (x ) não ( ) não aplicável }\end{array}$ & Temperatura ambiente: $21,5^{\circ} \mathrm{C}$ \\
\hline Profundidade: $16,43 \mathrm{~m}$ & \\
\hline Diâmetro: $1,61 \mathrm{~m}$ &
\end{tabular}

\begin{tabular}{|l|l|}
\hline Responsável do Projeto: Renata & No. Coleta: 02 \\
\hline Matriz (material a ser analisado): água & Data/hora da coleta: 17/10/11 as 10h \\
\hline Análise requerida: Metais & Nível d'água: N.A. \\
\hline Ponto de estudo: P4 & UTM_Y (m) 7368929,00 \\
\hline Localização: UTM_X (m) 332189,00 & $\begin{array}{l}\text { Chuva no momento da coleta: } \\
(\quad) \text { sim ( } \text { ) não ( ) não aplicável }\end{array}$ \\
\hline $\begin{array}{l}\text { Chuva nas últimas 48 horas: } \\
(\text { x ) sim ( ) não ( ) não aplicável }\end{array}$ & Temperatura ambiente: $36,8^{\circ} \mathrm{C}$ \\
\hline Profundidade: 55,0 m & \\
\hline Diâmetro: N.A. &
\end{tabular}

\begin{tabular}{|l|l|}
\hline Responsável do Projeto: Renata & No. Coleta: 02 \\
\hline Matriz (material a ser analisado): água & Data/hora da coleta: $17 / 10 / 11$ as $8 \mathrm{~h}$ \\
\cline { 1 - 2 } Análise requerida: Metais & Nível d'água: $16,37 \mathrm{~m}$ \\
\hline Ponto de estudo: P8 & UTM_Y (m) 7366588,00 \\
\hline Localização: UTM_X (m) 333841,00 & $\begin{array}{l}\text { Chuva no momento da coleta: } \\
(\quad) \text { sim ( } \mathrm{x}) \text { não ( ) não aplicável }\end{array}$ \\
\hline $\begin{array}{l}\text { Chuva nas últimas } 48 \text { horas: } \\
\text { ( x ) sim ( ) não ( ) não aplicável }\end{array}$ & Temperatura ambiente: $36,8^{\circ} \mathrm{C}$ \\
\hline Profundidade: $19,40 \mathrm{~m}$ & \\
\hline Diâmetro: $1,00 \mathrm{~m}$ &
\end{tabular}

\begin{tabular}{|l|l|}
\hline Responsável do Projeto: Renata & No. Coleta: 02 \\
\cline { 1 - 2 } Matriz (material a ser analisado): ÁGUA & Data/hora da coleta: 19/10/11 as 8h \\
\cline { 1 - 2 } Análise requerida: Metais & Nível d'água: 5,84 m \\
\hline Ponto de estudo: P9 & UTM_Y (m) 7366892,00 \\
\hline Localização: UTM_X (m) 334172,00 & $\begin{array}{l}\text { Chuva no momento da coleta: } \\
(\quad) \text { sim ( x ) não ( ) não aplicável }\end{array}$ \\
\hline $\begin{array}{l}\text { Chuva nas últimas 48 horas: } \\
\text { Profundidade: } 9,36 \mathrm{~m}\end{array}$ & Temperatura ambiente: $22,8^{\circ} \mathrm{C}$ \\
\hline Diâmetro: $1,00 \mathrm{~m}$ & \\
\hline
\end{tabular}




\begin{tabular}{|l|l|}
\hline Responsável do Projeto: Renata & No. Coleta: 02 \\
\cline { 1 - 2 } Matriz (material a ser analisado): água & Data/hora da coleta: 19/10/11 as 10h \\
\hline Análise requerida: Metais & Nível d'água: N.A. \\
\hline Ponto de estudo: nascente & UTM_Y (m) 7366622,68 \\
\hline Localização: UTM_X (m) 333908,06 & $\begin{array}{l}\text { Chuva no momento da coleta: } \\
(\quad) \text { sim (x ) não ( ) não aplicável }\end{array}$ \\
\hline $\begin{array}{l}\text { Chuva nas últimas 48 horas: } \\
(\quad) \text { sim ( x ) não ( ) não aplicável }\end{array}$ & Temperatura ambiente: $22,8^{\circ} \mathrm{C}$ \\
\hline Profundidade: N.A. & \\
\hline Diâmetro: N.A. &
\end{tabular}

\begin{tabular}{|l|l|}
\hline Responsável do Projeto: Renata & No. Coleta: 02 \\
\cline { 1 - 2 } Matriz (material a ser analisado): água & Data/hora da coleta: $18 / 10 / 11$ as $8 \mathrm{~h}$ \\
\cline { 1 - 2 } Análise requerida: Metais & Nível d'água: N.A \\
\hline Ponto de estudo: represa Billings & UTM_Y (m) 7367040,00 \\
\hline Localização: UTM_X (m) 334276,00 & $\begin{array}{l}\text { Chuva no momento da coleta: } \\
(\quad) \text { sim ( x ) não ( ) não aplicável }\end{array}$ \\
\hline $\begin{array}{l}\text { Chuva nas últimas 48 horas: } \\
\text { Prim ( x ) não ( ) não aplicável }\end{array}$ & Temperatura ambiente: $21,5^{\circ} \mathrm{C}$ \\
\hline Profundidade: N.A. & \\
\hline Diâmetro: N.A. &
\end{tabular}




\begin{tabular}{|l|l|}
\hline Responsável do Projeto: Renata & No. Coleta: 03 \\
\hline Matriz (material a ser analisado): ÁGUA & Data/hora da coleta: 06/12/11 as $8 \mathrm{~h}$ \\
\hline Análise requerida: Metais & Nível d'água: $12,0 \mathrm{~m}$ \\
\hline Ponto de estudo: P1 & UTM_Y (m) 7370388,00 \\
\hline Localização: UTM X (m) 332050,00 & $\begin{array}{l}\text { Chuva no momento da coleta: } \\
(\mathrm{x}) \text { sim ( ) não ( ) não aplicável }\end{array}$ \\
\hline $\begin{array}{l}\text { Chuva nas últimas 48 horas: } \\
(\mathrm{x}) \text { sim ( ) não ( ) não aplicável }\end{array}$ & Temperatura ambiente: $25,8{ }^{\circ} \mathrm{C}$ \\
\hline Profundidade: $16,43 \mathrm{~m}$ & \\
\hline Diâmetro: $1,61 \mathrm{~m}$ &
\end{tabular}

\begin{tabular}{|l|l|}
\hline Responsável do Projeto: Renata & No. Coleta: 03 \\
\hline Matriz (material a ser analisado): água & Data/hora da coleta: 05/12/11 as $8 \mathrm{~h}$ \\
\hline Análise requerida: Metais & Nível d'água: N.A. \\
\hline Ponto de estudo: P4 & UTM_Y (m) 7368929,00 \\
\hline Localização: UTM_X (m) 332189,00 & $\begin{array}{l}\text { Chuva no momento da coleta: } \\
(\mathrm{x}) \text { sim ( ) não ( ) não aplicável }\end{array}$ \\
\hline $\begin{array}{l}\text { Chuva nas últimas 48 horas: } \\
(\mathrm{x}) \text { sim ( ) não ( ) não aplicável }\end{array}$ & Temperatura ambiente: $28,5^{\circ} \mathrm{C}$ \\
\hline Profundidade: 55,0 m & \\
\hline Diâmetro: N.A. & \\
\hline
\end{tabular}

\begin{tabular}{|l|l|}
\hline Responsável do Projeto: Renata & No. Coleta: 03 \\
\hline Matriz (material a ser analisado): ÁGUA & Data/hora da coleta: 06/12/11 as 10h \\
\hline Análise requerida: Metais & Nível d'água: $16,37 \mathrm{~m}$ \\
\hline Ponto de estudo: P8 & UTM_Y (m) 7366588,00 \\
\hline Localização: UTM_X (m) 333841,00 & $\begin{array}{l}\text { Chuva no momento da coleta: } \\
(\mathrm{x}) \text { sim ( ) não ( ) não aplicável }\end{array}$ \\
\hline $\begin{array}{l}\text { Chuva nas últimas 48 horas: } \\
(\mathrm{x}) \text { sim ( ) não ( ) não aplicável }\end{array}$ & Temperatura ambiente: $25,8^{\circ} \mathrm{C}$ \\
\hline Profundidade: $19,40 \mathrm{~m}$ & \\
\hline Diâmetro: $1,00 \mathrm{~m}$ &
\end{tabular}

\begin{tabular}{|l|l|}
\hline Responsável do Projeto: Renata & No. Coleta: 03 \\
\hline Matriz (material a ser analisado): ÁGUA & Data/hora da coleta: 06/12/11 as 9h \\
\cline { 1 - 2 } Análise requerida: Metais & Nível d'água: 6,0 \\
\hline Ponto de estudo: P9 & UTM_Y (m) 7366892,00 \\
\hline Localização: UTM_X (m) 334172,00 & $\begin{array}{l}\text { Chuva no momento da coleta: } \\
(\mathrm{x}) \text { sim ( ) não ( ) não aplicável }\end{array}$ \\
\hline $\begin{array}{l}\text { Chuva nas últimas 48 horas: } \\
(\mathrm{x}) \text { sim ( ) não ( ) não aplicável }\end{array}$ & Temperatura ambiente: $25,8^{\circ} \mathrm{C}$ \\
\hline Profundidade: $9,36 \mathrm{~m}$ & \\
\hline Diâmetro: $1,0 \mathrm{~m}$ &
\end{tabular}




\begin{tabular}{|l|l|}
\hline Responsável do Projeto: Renata & No. Coleta: 03 \\
\hline Matriz (material a ser analisado): ÁGUA & Data/hora da coleta: 06/12/11 as $11 \mathrm{~h}$ \\
\hline Análise requerida: Metais & Nível d'água: N.A. \\
\hline Ponto de estudo: nascente & UTM_Y (m) 7366622,68 \\
\hline Localização: UTM_X (m) 333908,06 & $\begin{array}{l}\text { Chuva no momento da coleta: } \\
(\mathrm{x}) \text { sim ( ) não ( ) não aplicável }\end{array}$ \\
\hline $\begin{array}{l}\text { Chuva nas últimas 48 horas: } \\
\text { ( x ) sim ( ) não ( ) não aplicável }\end{array}$ & Temperatura ambiente: $25,8^{\circ} \mathrm{C}$ \\
\hline Profundidade: N.A. & \\
\hline Diâmetro: N.A. & \\
\hline
\end{tabular}

\begin{tabular}{|l|l|}
\hline Responsável do Projeto: Renata & No. Coleta: 03 \\
\hline Matriz (material a ser analisado): água & Data/hora da coleta: 07/12/11 as 10h \\
\hline Análise requerida: Metais & Nível d'água: N.A \\
\hline Ponto de estudo: represa Billings & UTM_Y (m) 7367040,00 \\
\hline Localização: UTM_X (m) 334276,00 & $\begin{array}{l}\text { Chuva no momento da coleta: } \\
\text { ( ) sim ( x ) não ( ) não aplicável }\end{array}$ \\
\hline $\begin{array}{l}\text { Chuva nas últimas 48 horas: } \\
\text { x ) sim ( ) não ( ) não aplicável }\end{array}$ & Temperatura ambiente: $28,2{ }^{\circ} \mathrm{C}$ \\
\hline Profundidade: N.A. & \\
\hline Diâmetro: N.A. &
\end{tabular}




\begin{tabular}{|l|l|}
\hline Responsável do Projeto: Renata & No. Coleta: 04 \\
\hline Matriz (material a ser analisado): água & Data/hora da coleta: 05/03/2012 as $8 \mathrm{~h}$ \\
\hline Análise requerida: Metais & Nível d'água: $11,80 \mathrm{~m}$ \\
\hline Ponto de estudo: P1 & UTM_Y (m) 7370388,00 \\
\hline Localização: UTM_X (m) 332050,00 & $\begin{array}{l}\text { Chuva no momento da coleta: } \\
(\quad) \text { sim ( x ) não ( ) não aplicável }\end{array}$ \\
\hline $\begin{array}{l}\text { Chuva nas últimas 48 horas: } \\
(\quad \text { sim (x ) não ( ) não aplicável }\end{array}$ & Temperatura ambiente: $31^{\circ} \mathrm{C}$ \\
\hline Profundidade: $16,43 \mathrm{~m}$ & \\
\hline Diâmetro: $1,61 \mathrm{~m}$ &
\end{tabular}

\begin{tabular}{|l|l|}
\hline Responsável do Projeto: Renata & No. Coleta: 04 \\
\hline Matriz (material a ser analisado): água & Data/hora da coleta: 05/03/2012 as 9h \\
\hline Análise requerida: Metais & Nível d'água: N.A. \\
\hline Ponto de estudo: P4 & UTM_Y (m) 7368929,00 \\
\hline Localização: UTM_X (m) 332189,00 & $\begin{array}{l}\text { Chuva no momento da coleta: } \\
(\quad \text { ) sim ( } \text { x ) não ( ) não aplicável }\end{array}$ \\
\hline $\begin{array}{l}\text { Chuva nas últimas 48 horas: } \\
(\quad \text { sim ( x ) não ( ) não aplicável }\end{array}$ & Temperatura ambiente: $31^{\circ} \mathrm{C}$ \\
\hline Profundidade: 55,0 m & \\
\hline Diâmetro: N.A. &
\end{tabular}

\begin{tabular}{|l|l|}
\hline Responsável do Projeto: Renata & No. Coleta: 04 \\
\hline Matriz (material a ser analisado): água & Data/hora da coleta: 06/03/2012 as 9h \\
\hline Análise requerida: Metais & Nível d'água: $16,37 \mathrm{~m}$ \\
\hline Ponto de estudo: P8 & UTM_Y (m) 7366588,00 \\
\hline Localização: UTM X (m) 333841,00 & $\begin{array}{l}\text { Chuva no momento da coleta: } \\
(\quad) \text { sim ( } \text { ) não ( ) não aplicável }\end{array}$ \\
\hline $\begin{array}{l}\text { Chuva nas últimas 48 horas: } \\
\text { P ) sim ( x ) não ( ) não aplicável }\end{array}$ & Temperatura ambiente: $31^{\circ} \mathrm{C}$ \\
\hline Profundidade: $19,40 \mathrm{~m}$ & \\
\hline Diâmetro: $1,00 \mathrm{~m}$ &
\end{tabular}

\begin{tabular}{|l|l|}
\hline Responsável do Projeto: Renata & No. Coleta: 04 \\
\cline { 1 - 2 } Matriz (material a ser analisado): água & Data/hora da coleta: 06/03/2012 as 8h \\
\cline { 1 - 2 } Análise requerida: Metais & Nível d'água: 7,50 m \\
\hline Ponto de estudo: P9 & UTM_Y (m) 7366892,00 \\
\hline Localização: UTM_X (m) 334172,00 & $\begin{array}{l}\text { Chuva no momento da coleta: } \\
\text { ( ) sim ( x ) não ( ) não aplicável }\end{array}$ \\
\hline $\begin{array}{l}\text { Chuva nas últimas 48 horas: } \\
\text { Profundidade: } 9,36 \mathrm{~m}\end{array}$ & Temperatura ambiente: $31^{\circ} \mathrm{C}$ \\
\hline Diâmetro: $1,00 \mathrm{~m}$ & \\
\hline
\end{tabular}




\begin{tabular}{|l|l|}
\hline Responsável do Projeto: Renata & No. Coleta: 04 \\
\hline Matriz (material a ser analisado): água & Data/hora da coleta: 06/03/2012 as 10h \\
\hline Análise requerida: Metais & Nível d'água: N.A. \\
\hline Ponto de estudo: nascente & UTM_Y (m) 7366622,68 \\
\hline Localização: UTM_X (m) 333908,06 & $\begin{array}{l}\text { Chuva no momento da coleta: } \\
(\quad) \text { sim ( } \text { x ) não ( ) não aplicável }\end{array}$ \\
\hline $\begin{array}{l}\text { Chuva nas últimas 48 horas: } \\
(\quad \text { ) sim ( x) não ( ) não aplicável }\end{array}$ & Temperatura ambiente: $31^{\circ} \mathrm{C}$ \\
\hline Profundidade: N.A. & \\
\hline Diâmetro: N.A. &
\end{tabular}

\begin{tabular}{|l|l|}
\hline Responsável do Projeto: Renata & No. Coleta: 04 \\
\hline Matriz (material a ser analisado): água & Data/hora da coleta: 08/03/12 as 10h \\
\hline Análise requerida: Metais & Nível d'água: N.A \\
\hline Ponto de estudo: represa Billings & UTM_Y (m) 7367040,00 \\
\hline Localização: UTM_X (m) 334276,00 & $\begin{array}{l}\text { Chuva no momento da coleta: } \\
\text { ( ) sim ( x ) não ( ) não aplicável }\end{array}$ \\
\hline $\begin{array}{l}\text { Chuva nas últimas 48 horas: } \\
\text { ( }) \text { sim ( x ) não ( ) não aplicável }\end{array}$ & Temperatura ambiente: $30^{\circ} \mathrm{C}$ \\
\hline Profundidade: N.A. & \\
\hline Diâmetro: N.A. &
\end{tabular}




\begin{tabular}{|l|l|}
\hline Responsável do Projeto: Renata & No. Coleta: 05 \\
\hline Matriz (material a ser analisado): água & Mês de coleta: $29 / 05 / 2012$ as $10 \mathrm{~h}$ \\
\cline { 1 - 2 } Análise requerida: Metais & Nível d'água: $11,90 \mathrm{~m}$ \\
\hline Ponto de estudo: P1 & UTM_Y (m) 7370388,00 \\
\hline Localização: UTM X (m) 332050,00 & $\begin{array}{l}\text { Chuva no momento da coleta: } \\
(\quad) \text { sim ( x ) não ( ) não aplicável }\end{array}$ \\
\hline $\begin{array}{l}\text { Chuva nas últimas 48 horas: } \\
(\quad \text { sim ( x ) não ( ) não aplicável }\end{array}$ & Temperatura ambiente: $27^{\circ} \mathrm{C}$ máxima \\
\hline Profundidade: $16,43 \mathrm{~m}$ & \\
\hline Diâmetro: $1,61 \mathrm{~m}$ & \\
\hline
\end{tabular}

\begin{tabular}{|l|l|}
\hline Responsável do Projeto: Renata & No. Coleta: 05 \\
\hline Matriz (material a ser analisado): água & Mês de coleta: 29/05/2012 as $11 \mathrm{~h}$ \\
\hline Análise requerida: Metais & Nível d'água: N.A. \\
\hline Ponto de estudo: P4 & UTM_Y (m) 7368929,00 \\
\hline Localização: UTM_X (m) 332189,00 & $\begin{array}{l}\text { Chuva no momento da coleta: } \\
(\quad) \text { sim ( } \text { x ) não ( ) não aplicável }\end{array}$ \\
\hline $\begin{array}{l}\text { Chuva nas últimas 48 horas: } \\
\text { ( } \quad \text { sim ( x ) não ( ) não aplicável }\end{array}$ & Temperatura ambiente: $27^{\circ} \mathrm{C}$ \\
\hline Profundidade: 55,0 m & \\
\hline Diâmetro: N.A. &
\end{tabular}

\begin{tabular}{|l|l|}
\hline Responsável do Projeto: Renata & No. Coleta: 05 \\
\hline Matriz (material a ser analisado): água & Mês de coleta: 30/05/2012 as 9h \\
\cline { 1 - 2 } Análise requerida: Metais & Nível d'água: $15,80 \mathrm{~m}$ \\
\hline Ponto de estudo: P8 & UTM_Y (m) 7366588,00 \\
\hline Localização: UTM_X (m) 333841,00 & $\begin{array}{l}\text { Chuva no momento da coleta: } \\
(\quad) \text { sim ( x ) não ( ) não aplicável }\end{array}$ \\
\hline $\begin{array}{l}\text { Chuva nas últimas 48 horas: } \\
\text { ( }) \text { sim ( x ) não ( ) não aplicável }\end{array}$ & Temperatura ambiente: $28^{\circ} \mathrm{C}$ \\
\hline Profundidade: $19,40 \mathrm{~m}$ & \\
\hline Diâmetro: $1,00 \mathrm{~m}$ &
\end{tabular}

\begin{tabular}{|l|l|}
\hline Responsável do Projeto: Renata & No. Coleta: 05 \\
\cline { 1 - 2 } Matriz (material a ser analisado): água & Mês de coleta: $29 / 05 / 2012$ as $8 \mathrm{~h}$ \\
\cline { 1 - 2 } Análise requerida: Metais & Nível d'água: 5,35 m \\
\hline Ponto de estudo: P9 & UTM_Y (m) 7366892,00 \\
\hline Localização: UTM_X (m) 334172,00 & $\begin{array}{l}\text { Chuva no momento da coleta: } \\
(\quad) \text { sim ( x ) não ( ) não aplicável }\end{array}$ \\
\hline $\begin{array}{l}\text { Chuva nas últimas 48 horas: } \\
\text { ( ) sim ( x ) não ( ) não aplicável }\end{array}$ & Temperatura ambiente: $27^{\circ} \mathrm{C}$ \\
\hline Profundidade: 9,36 m & \\
\hline Diâmetro: $1,00 \mathrm{~m}$ &
\end{tabular}




\begin{tabular}{|l|l|}
\hline Responsável do Projeto: Renata & No. Coleta: 05 \\
\hline Matriz (material a ser analisado): água & Mês de coleta: 31/05/12 as 10h \\
\hline Análise requerida: Metais & Nível d'água: N.A. \\
\hline Ponto de estudo: nascente & UTM_Y (m) 7366622,68 \\
\hline Localização: UTM_X (m) 333908,06 & $\begin{array}{l}\text { Chuva no momento da coleta: } \\
(\quad) \text { sim ( } \text { ) não ( ) não aplicável }\end{array}$ \\
\hline $\begin{array}{l}\text { Chuva nas últimas 48 horas: } \\
(\quad \text { sim ( x ) não ( ) não aplicável }\end{array}$ & Temperatura ambiente: $2{ }^{\circ} \mathrm{C}$ \\
\hline Profundidade: N.A. & \\
\hline Diâmetro: N.A. &
\end{tabular}

\begin{tabular}{|l|l|}
\hline Responsável do Projeto: Renata & No. Coleta: 05 \\
\hline Matriz (material a ser analisado): água & Mês de coleta: 31/05/12 as $11 \mathrm{~h}$ \\
\hline Análise requerida: Metais & Nível d'água: N.A \\
\hline Ponto de estudo: represa Billings & UTM_Y (m) 7367040,00 \\
\hline Localização: UTM_X (m) 334276,00 & $\begin{array}{l}\text { Chuva no momento da coleta: } \\
(\quad) \text { sim ( x) não ( ) não aplicável }\end{array}$ \\
\hline $\begin{array}{l}\text { Chuva nas últimas 48 horas: } \\
\text { ( }) \text { sim ( x ) não ( ) não aplicável }\end{array}$ & Temperatura ambiente: $23^{\circ} \mathrm{C}$ \\
\hline Profundidade: N.A. & \\
\hline Diâmetro: N.A. &
\end{tabular}




\begin{tabular}{|l|l|}
\hline Responsável do Projeto: Renata & No. Coleta: 06 \\
\cline { 1 - 2 } Matriz (material a ser analisado): água & Mês de coleta: $17 / 07 / 13$ as $8 \mathrm{~h}$ \\
\cline { 1 - 2 } Análise requerida: Metais & Nível d'água: $11,90 \mathrm{~m}$ \\
\hline Ponto de estudo: P1 & UTM_Y (m) 7370388,00 \\
\hline Localização: UTM_X (m) 332050,00 & $\begin{array}{l}\text { Chuva no momento da coleta: } \\
(\mathrm{x}) \text { sim ( ) não ( ) não aplicável }\end{array}$ \\
\hline $\begin{array}{l}\text { Chuva nas últimas 48 horas: } \\
(\mathrm{x}) \text { sim ( ) não ( ) não aplicável }\end{array}$ & Temperatura ambiente: $16,7^{\circ} \mathrm{C}$ \\
\hline Profundidade: $16,43 \mathrm{~m}$ & \\
\hline Diâmetro: $1,61 \mathrm{~m}$ & \\
\hline
\end{tabular}

\begin{tabular}{|l|l|}
\hline Responsável do Projeto: Renata & No. Coleta: 06 \\
\hline Matriz (material a ser analisado): água & Mês de coleta: $17 / 07 / 13$ as 9h \\
\hline Análise requerida: Metais & Nível d'água: N.A. \\
\hline Ponto de estudo: P4 & UTM_Y (m) 7368929,00 \\
\hline Localização: UTM_X (m) 332189,00 & $\begin{array}{l}\text { Chuva no momento da coleta: } \\
(\quad) \text { sim ( } \text { x ) não ( ) não aplicável }\end{array}$ \\
\hline $\begin{array}{l}\text { Chuva nas últimas 48 horas: } \\
(\quad) \text { sim ( ) não ( ) não aplicável }\end{array}$ & Temperatura ambiente: $27,9{ }^{\circ} \mathrm{C}$ \\
\hline Profundidade: 55,0 m & \\
\hline Diâmetro: N.A. &
\end{tabular}

\begin{tabular}{|l|l|}
\hline Responsável do Projeto: Renata & No. Coleta: 06 \\
\hline Matriz (material a ser analisado): água & Mês de coleta: $19 / 07 / 13$ as $10: 30 \mathrm{~h}$ \\
\cline { 1 - 2 } Análise requerida: Metais & Nível d'água: $15,60 \mathrm{~m}$ \\
\hline Ponto de estudo: P8 & UTM_Y (m) 7366588,00 \\
\hline Localização: UTM_X (m) 333841,00 & $\begin{array}{l}\text { Chuva no momento da coleta: } \\
(\mathrm{x}) \text { sim ( ) não ( ) não aplicável }\end{array}$ \\
\hline $\begin{array}{l}\text { Chuva nas últimas } 48 \text { horas: } \\
\text { (x) sim ( ) não ( ) não aplicável }\end{array}$ & $\begin{array}{l}\text { Temperatura ambiente: } \\
\text { mínima } 11,9^{\circ} \mathrm{C} \text { e máxima } 16,7^{\circ} \mathrm{C}\end{array}$ \\
\hline Profundidade: $19,40 \mathrm{~m}$ &
\end{tabular}

\begin{tabular}{|l|l|}
\hline Responsável do Projeto: Renata & No. Coleta: 06 \\
\cline { 1 - 2 } Matriz (material a ser analisado): água & Mês de coleta: $18 / 07 / 13$ as 9h \\
\cline { 1 - 2 } Análise requerida: Metais & Nível d'água: 5,30 m \\
\hline Ponto de estudo: P9 & UTM_Y (m) 7366892,00 \\
\hline Localização: UTM_X (m) 334172,00 & $\begin{array}{l}\text { Chuva no momento da coleta: } \\
(\quad) \text { sim ( } \mathrm{x} \text { ) não ( ) não aplicável }\end{array}$ \\
\hline $\begin{array}{l}\text { Chuva nas últimas 48 horas: } \\
\text { ( x ) sim ( ) não ( ) não aplicável }\end{array}$ & Temperatura ambiente: $27,9{ }^{\circ} \mathrm{C}$ \\
\hline Profundidade: 9,36 m & \\
\hline Diâmetro: $1,00 \mathrm{~m}$ &
\end{tabular}




\begin{tabular}{|l|l|}
\hline Responsável do Projeto: Renata & No. Coleta: 06 \\
\hline Matriz (material a ser analisado): água & Mês de coleta: 22/07/2012 as 9h \\
\hline Análise requerida: Metais & Nível d'água: N.A. \\
\hline Ponto de estudo: nascente & UTM_Y (m) 7366622,68 \\
\hline Localização: UTM_X (m) 333908,06 & $\begin{array}{l}\text { Chuva no momento da coleta: } \\
(\quad) \text { sim ( } x) \text { não ( ) não aplicável }\end{array}$ \\
\hline $\begin{array}{l}\text { Chuva nas últimas 48 horas: } \\
(x) \text { sim ( ) não ( ) não aplicável }\end{array}$ & Temperatura ambiente: $19,7^{\circ} \mathrm{C}$ \\
\hline Profundidade: N.A. & \\
\hline Diâmetro: N.A. &
\end{tabular}

\begin{tabular}{|l|l|}
\hline Responsável do Projeto: Renata & No. Coleta: 06 \\
\hline Matriz (material a ser analisado): água & Mês de coleta: $22 / 07 / 2012$ as $11 \mathrm{~h}$ \\
\hline Análise requerida: Metais & Nível d'água: N.A \\
\hline Ponto de estudo: represa Billings & UTM_Y (m) 7367040,00 \\
\hline Localização: UTM_X (m) 334276,00 & $\begin{array}{l}\text { Chuva no momento da coleta: } \\
\text { ( ) sim ( x ) não ( ) não aplicável }\end{array}$ \\
\hline $\begin{array}{l}\text { Chuva nas últimas 48 horas: } \\
\text { x ) sim ( ) não ( ) não aplicável }\end{array}$ & Temperatura ambiente: $19,7^{\circ} \mathrm{C}$ \\
\hline Profundidade: N.A. & \\
\hline Diâmetro: N.A. &
\end{tabular}


ANEXO B - MAPA 


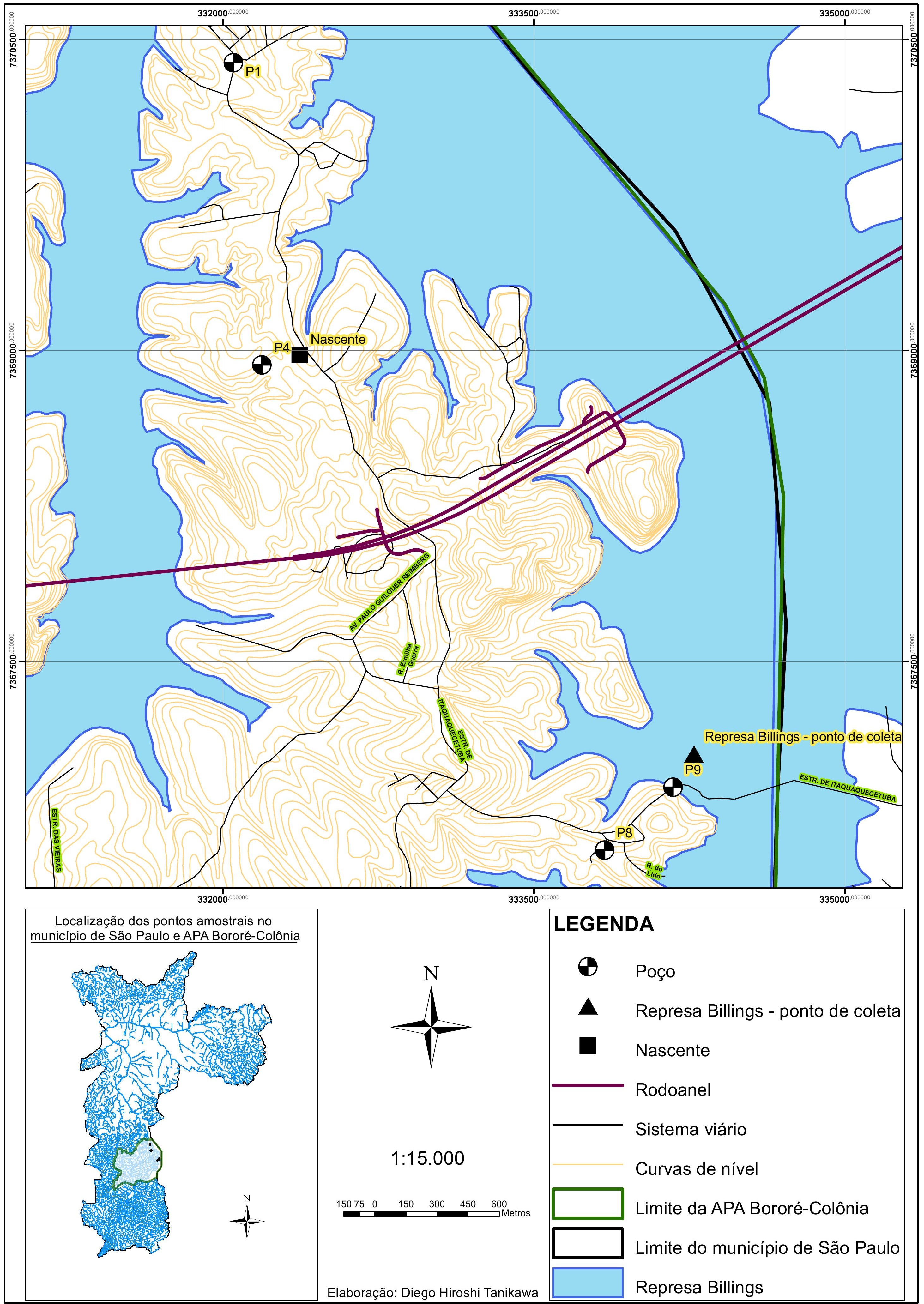


ANEXO C

Registro fotográfico dos sítios de coleta

Principal via de acesso entre os bairros de Grajaú e Ilha do Bororé: balsa 1
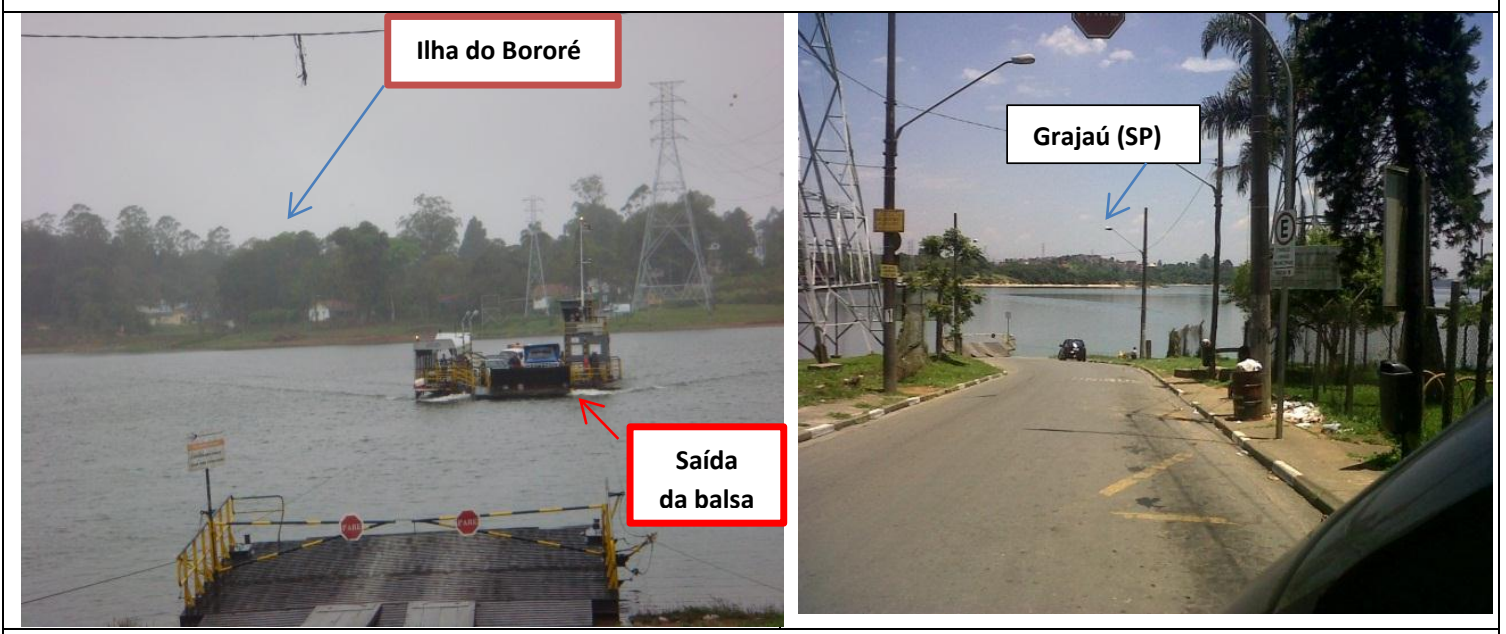

Vista da Ilha do Bororé localizada à margem esquerda da Represa Billings e local de coleta
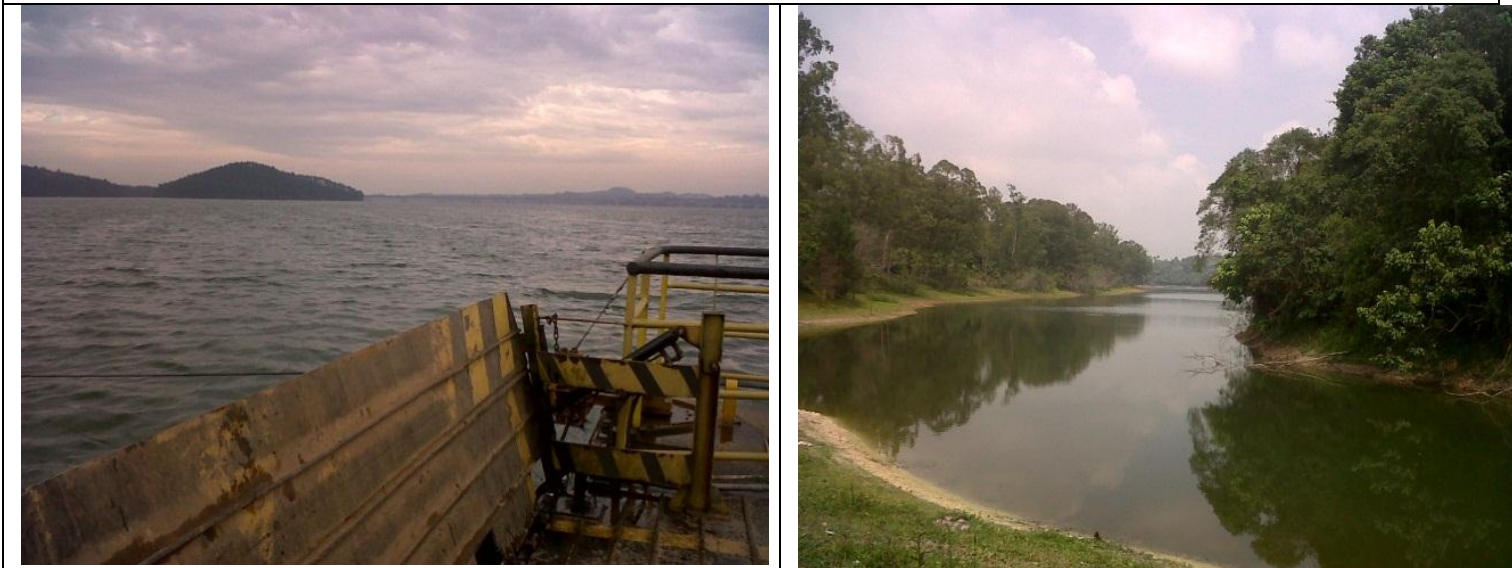

Sítio das coletas 


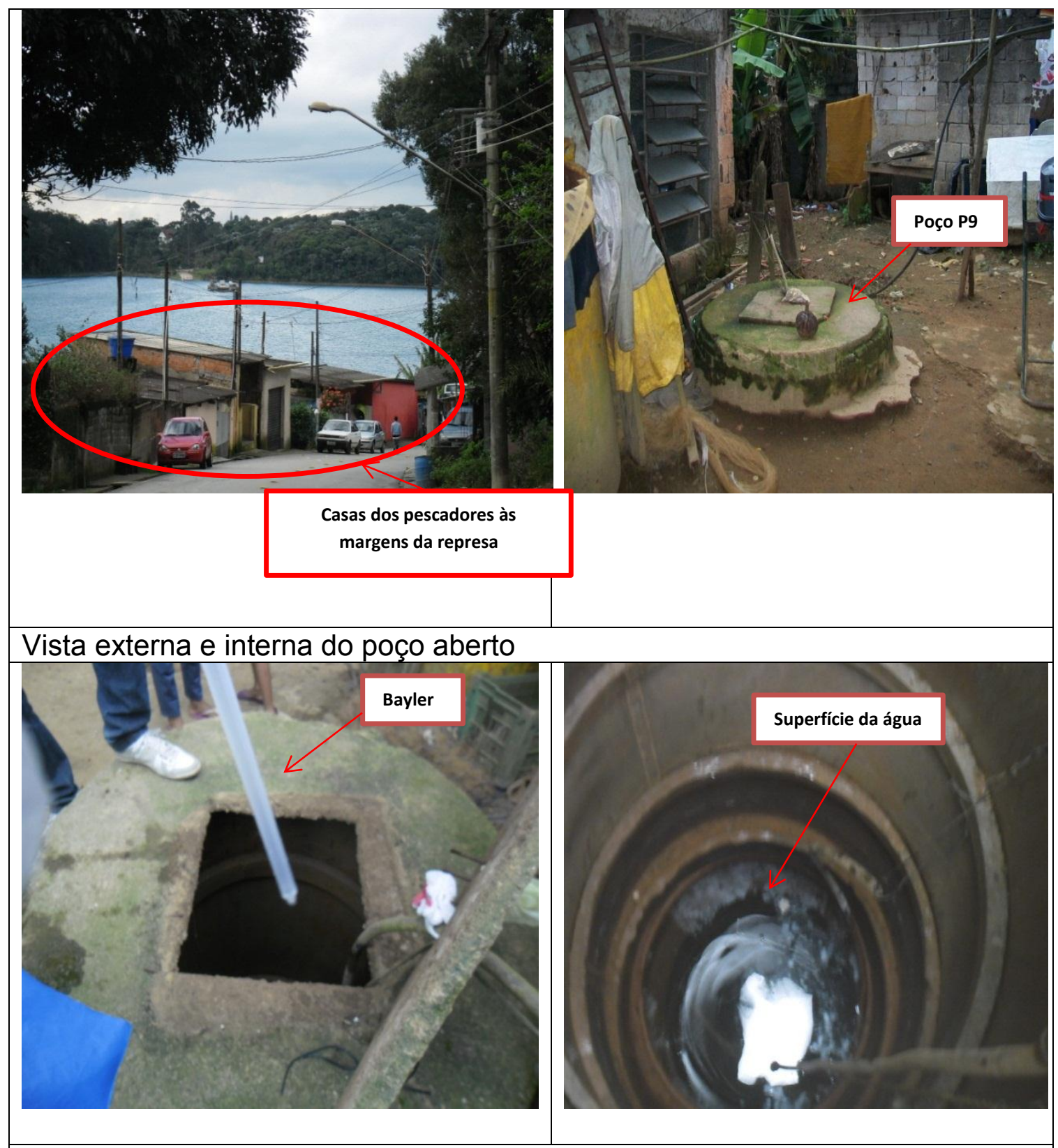

Filtração e medição de parâmetros físicos e químicos da água
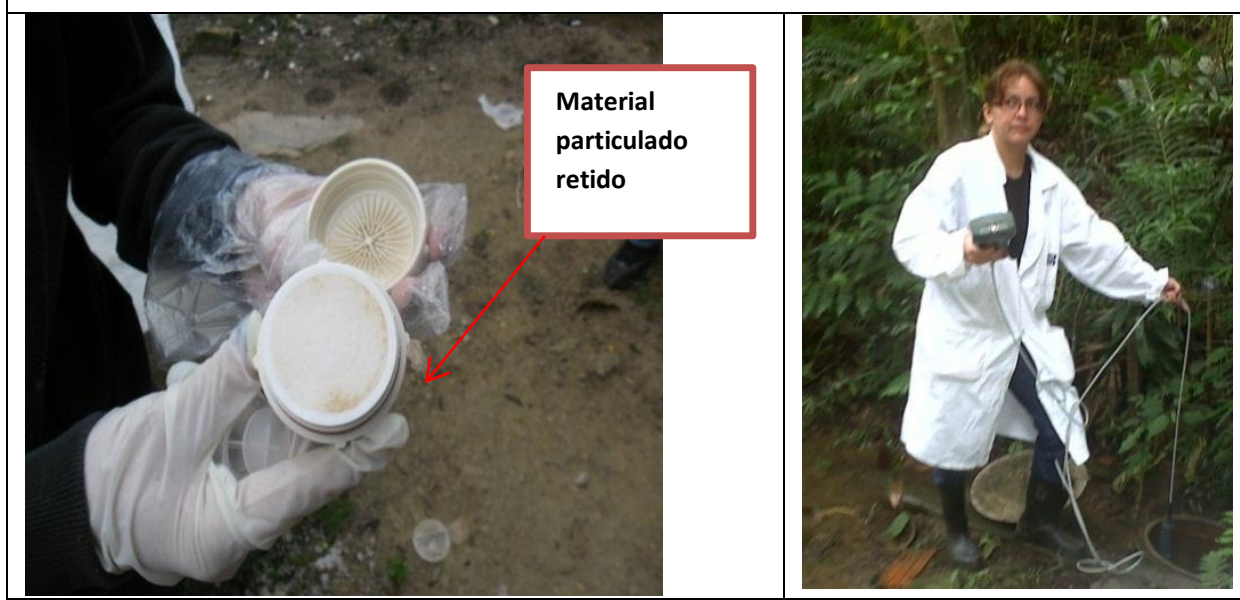


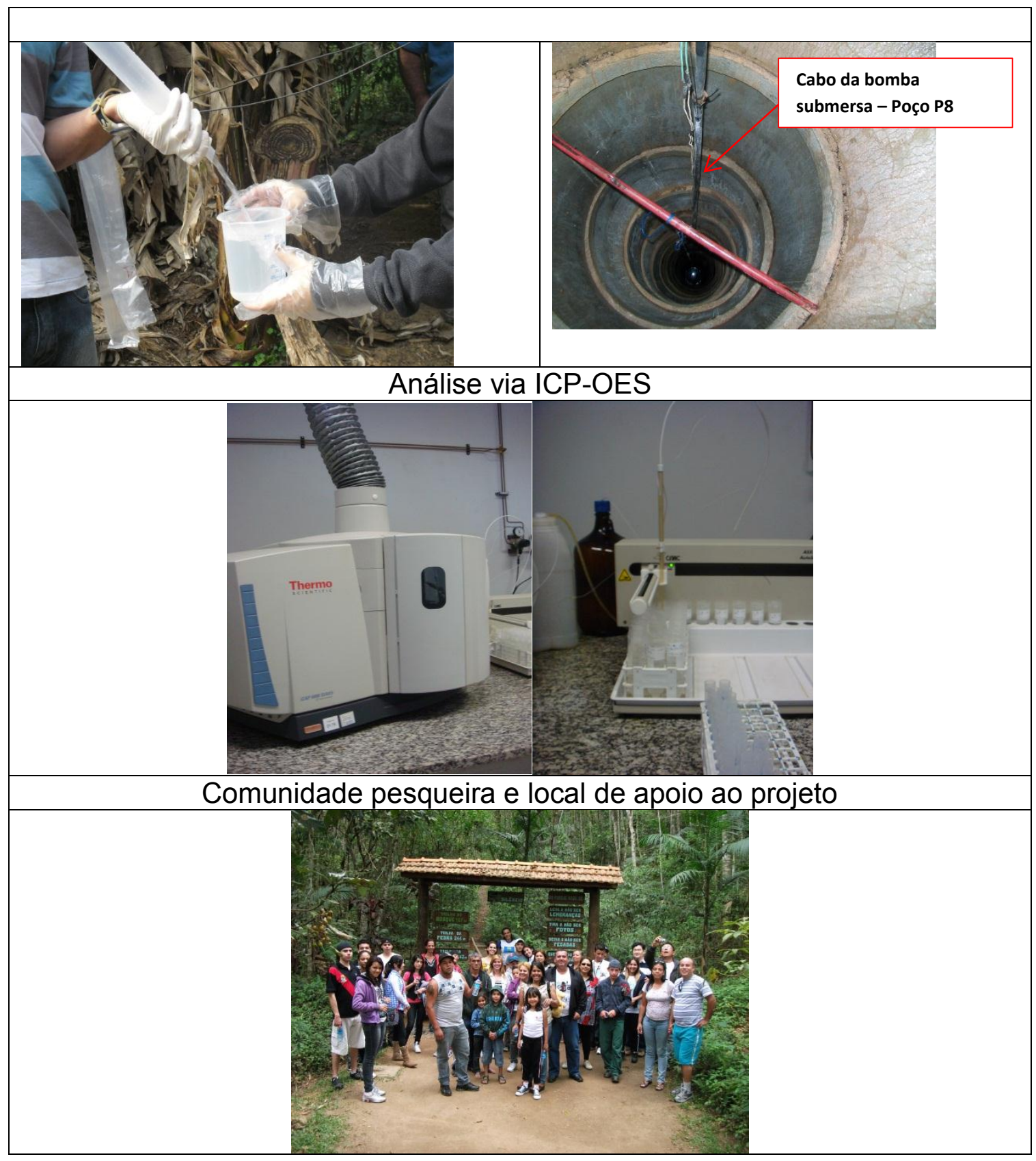

